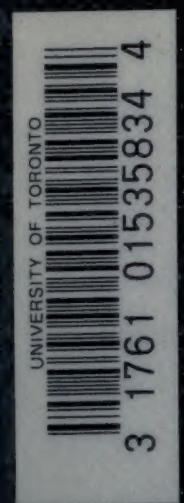




RECEIVED

FACITTY OF FOPRSTRT

DEG 19??

UNIVERSIIY OF TORONTO 



Digitized by the Internet Archive in 2007 with funding from Microsoft Corporation 


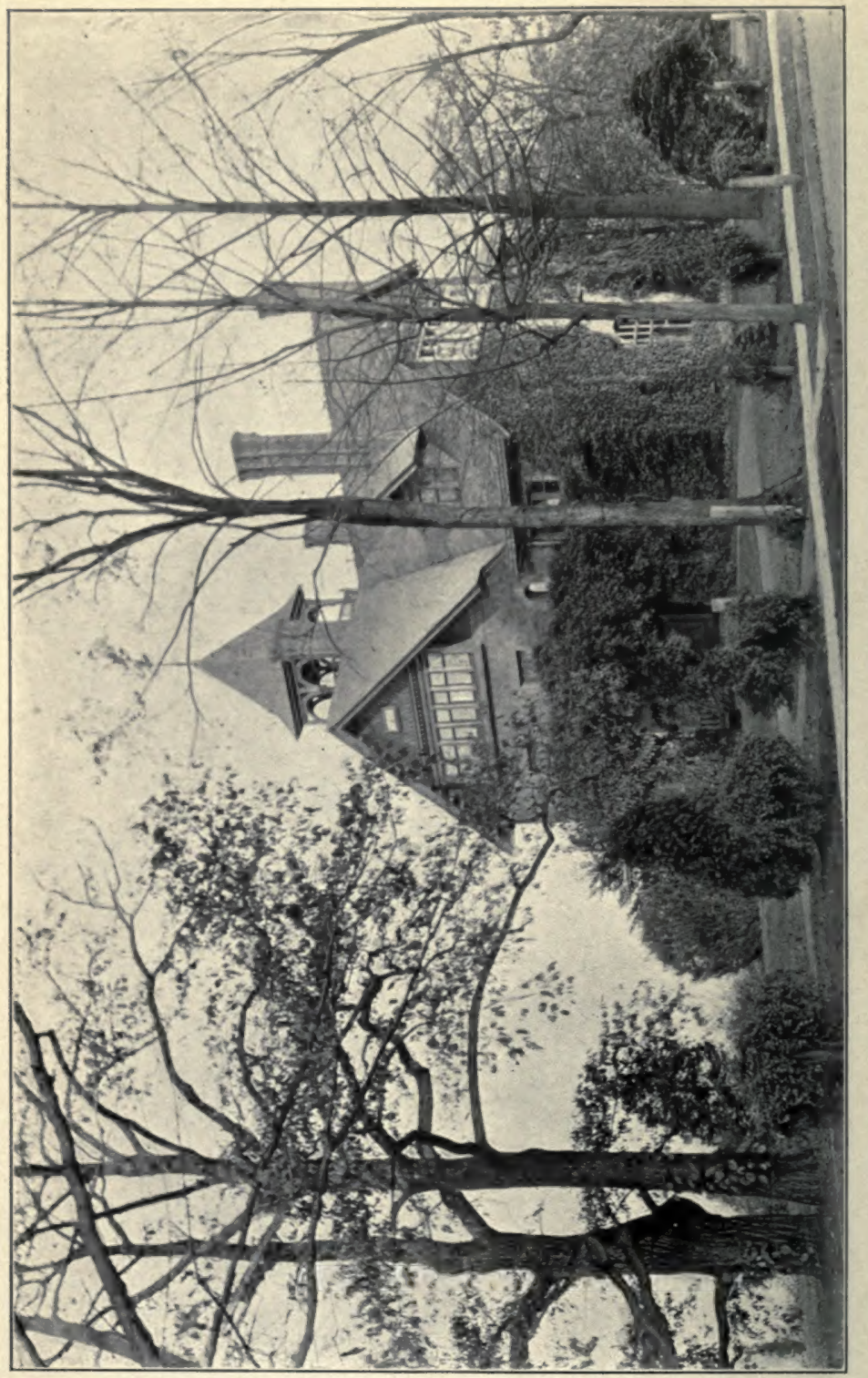

2 


\section{BIOGRAPHICAL RECORD}

OF THE

GRADUATES AND

FORMER STUDENTS

OF THE

\section{YALE FOREST SCHOOL}

WITH INTRODUCTORY PAPERS ON YALE IN THE FORESTRY MOVEMENT AND THE HISTORY OF THE YALE FOREST SCHOOL

Compiled AND PUBLISHED BY THE YALE FOREST SCHOOL

ASSISTED BY THE

Class SEcretaries BUREaU NEW $\overline{\text { HAVEN, }}$ 1913

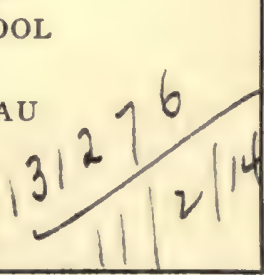

\section{LIBRARY}

FACULTY OF FORESTRY

UNIVERSITY OF TORONTO 


$$
\begin{aligned}
& \text { SD } \\
& 254 \\
& Y 3 A 5 \\
& 1913
\end{aligned}
$$


HISTORY OF THE YALE FOREST SCHOOL 



\section{YALE IN THE FORESTRY MOVEMENT}

\section{By Henry Solon Graves}

Director of the Yale Forest School, Ig00 to I9II, now Chief of the United States Forest Service

The Yale Forest School was established when the movement of forestry in this country was in its infancy-at a time when the majority of the people of the country were ignorant of, indifferent to, or opposed to the aims and methods of forestry. The history of the School has been coincident with a most remarkable development of forestry throughout the country. The Yale School has a very large share of credit for this development; without Yale and the other forest schools the results of the last decade could never have been achieved. No country has yet succeeded in establishing forestry on a permanent footing except through well trained foresters. Forestry had its real beginning in the United States when there were men to initiate the work of putting its principles into actual practice.

In the minds of the founders of the Yale School there was not only a recognition of the need of trained men to carry on the work of forestry, but there was also a determined purpose to set a high standard of education that would train its students for leadership in the development of the science and practice of forestry. No task before the School has been more difficult. In the early days the technical demands on the forester were small. Oftentimes his first work was purely administrative, for which a very elementary knowledge of forestry would suffice. The demand for men was at that time so great that a young man with but little training could secure a place with the Government or elsewhere. There was therefore a tremendous pressure for a short-cut education, and to omit many fundamental features of technical training that did not seem of immediate practical application. But the School consistently maintained its high technical requirements, because it was training men to develop forestry and not merely to fill certain positions that might be available. 
The keynote of forestry is foresight. In the first work of organizing forestry there must be a clear vision of future development. Otherwise no real progress is possible. Every step undertaken in handling a forest has an effect on its future condition, whether it involves the building of trails, the location of cuttings, the method of cuttings, or the organization of a protective system. The man who has a proper training can look ahead and guide his work to meet the requirements of a real upbuilding of his forest. The man with no such knowledge will invariably work on a basis of immediate expediency, without consideration of what is to be the ultimate development of the forest. Many do not appreciate the vital influence of single localized operations on the development of the forest in the future, because mistakes may not be discovered or good work appreciated for a long time.

Already the need for a high standard of forest education has been demonstrated. I regard the part Yale has been able to play in maintaining this standard as one of its largest achievements; it is the real reason for the School's leadership in forestry and the confidence it has acquired throughout the country. The graduates of the School have been leaders because they have had a point of view and knowledge beyond that needed for the every-day work which they first find to do.

In addition to the educational foundations secured at the School, the graduates have shown a spirit of public service and devotion to their work that has contributed largely to their leadership. The forestry movement will have a very vital influence on the internal development and lasting prosperity of the country. Every forester is working toward an end which will benefit the nation, whether he is in public service or in the employ of a lumber company. This body of men scattered throughout all the states constitutes an educational force that is irresistible.

Through the devoted work of its Faculty and the enthusiastic and consistent spirit of loyal service of its graduates, the Yale Forest School has already accomplished results which deserve high credit. Its work, however, is still in its infancy. In performing its part in developing public forest policies, both for the Nation and the states, in building up the science of forestry, 
and getting its principles in actual practice, Yale has a great opportunity and a great responsibility to serve the country. When we read the history of the School contained in this volume, let it be with the feeling that it tells of the foundation for a work which everyone associated with the School aims to do for the Nation. It is an account of the past to be of help for the future. 


\section{THE YALE FOREST SCHOOL AN HISTORICAL SKETCH \\ By James William Toumey}

Director of the Yale Forest School, and a professor in the School since its foundation

The first great step in forest conservation in the United States was taken in 1891 when, through the action of Congress, the President was given authority to set aside forest reservations. Previous to this time forestry in the United States was chiefly propaganda. There were less than a half dozen trained foresters in the entire country. It was soon found necessary, however, to appoint supervisors, forest rangers, and other forest officers to take charge of the newly created reservations. The work was organized with men having little or no knowledge of technical forestry. Even before the creation of the National forests some of the states had begun to develop a progressive forest policy and to acquire land for state forests. The beginnings were also made in forestry on privately owned timber land. At the beginning of the present century not only the National government but many of the states and, to some extent, private owners of large forest properties were seeking trained foresters.

As early as I 887 a course of lectures on technical forestry was given by Bernhard E. Fernow at the Massachusetts Agricultural College. This was the first instruction in forestry given by a trained forester at an educational institution in the United States. Prior to this date some of the agricultural colleges sustained chairs of botany and forestry combined. In no instance, however, were the men who occupied them trained foresters, nor did they teach technical forestry.

In 1898 Dr. Fernow resigned his position as chief of the Division of Forestry of the United States Department of Agriculture and organized and became director of the New York State College of Forestry at Cornell University. This was the first school of technical forestry in the United States. About 


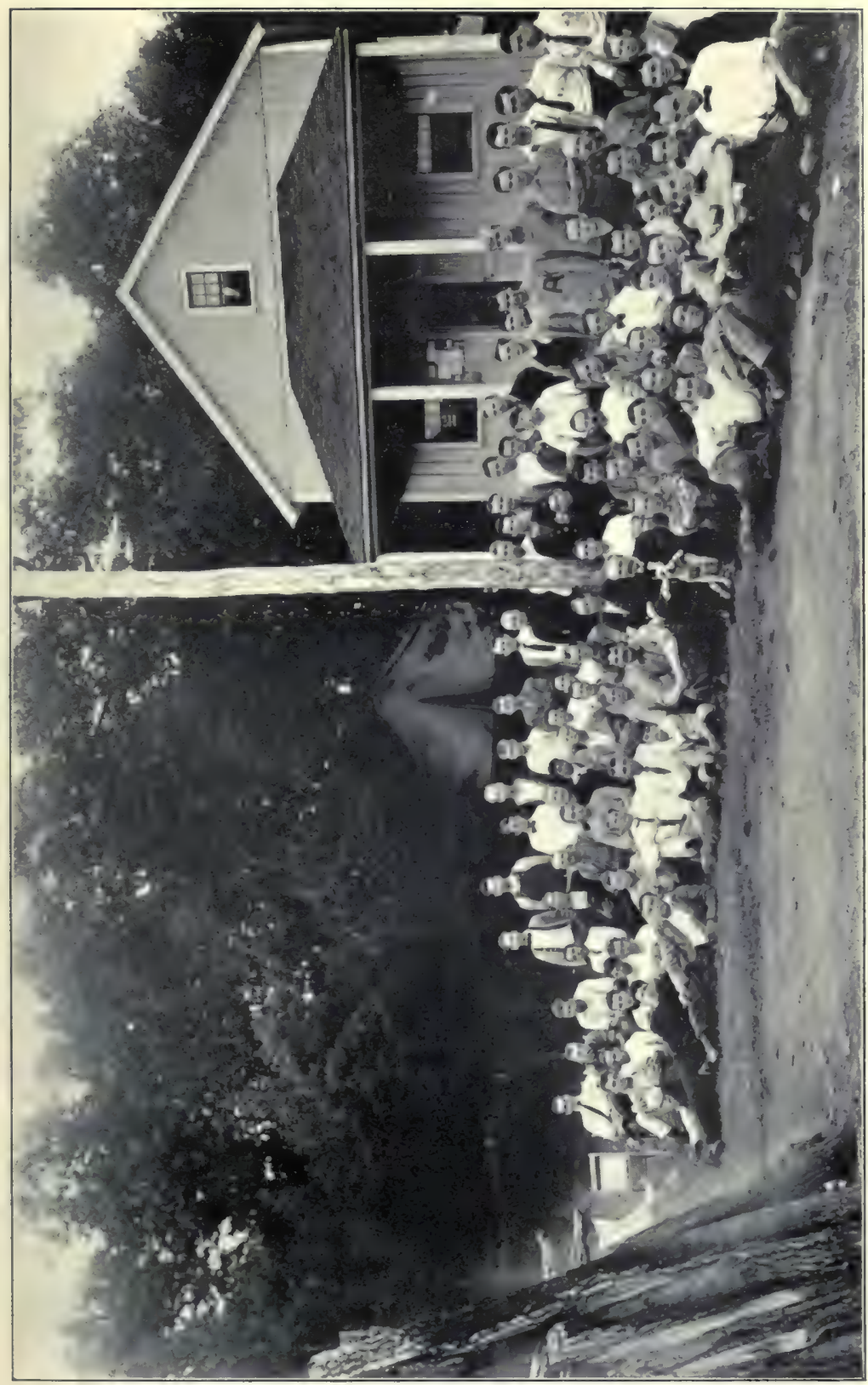

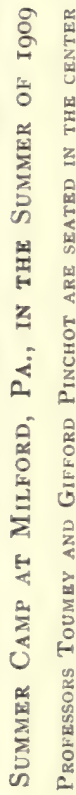



the same time a small private school was established by Carl A. Schenck at Biltmore, N. C. The former school was abandoned after three years of successful work through the lack of state support; the latter is still in existence.

The great impetus given to American forestry through the creation of the National forests, the activities of the separate states in furthering a progressive forest policy, and the rapid expanse of the work of the Division of Forestry under the new chief, Gifford Pinchot, created a demand almost over night for a large number of technically trained men. Mr. Pinchot had been trained in the forest schools of Europe and became the leading figure in American forestry. He soon realized that his vision of forest conservation could not be attained without an able corps of men thoroughly trained in technical forestry and familiar with American life and institutions. The two schools, at Cornell and Biltmore, with uncertain tenure of life, could not be depended upon to supply the large numbers of men immediately required and the continually increasing number that would probably be necessary for some years to come.

Early in the spring of Igoo it was announced by the President of Yale University that a gift of one hundred and fifty thousand dollars had been received to endow a graduate school of forestry. Two ideas of fundamental importance stand forth in this announcement; namely, an endowed institution and a graduate school. For the first time in America the new profession of forestry was placed upon a high plane requiring the best type of scholarship and a thorough scientific foundation. The fact of an endowed institution assured permanency and the possibility of substantial and gradual development.

The gift under which the School was founded was from Mr. and Mrs. James W. Pinchot and their sons, Gifford Pinchot and Amos R. E. Pinchot. It provided for a department in the University to be known as the Yale Forest School and a summer school of forestry at Milford, Pike County, Pa. The object of the School, as expressed in the terms of the gift, is both instruction and research in forestry. The University in accepting the gift agreed to provide the necessary buildings to house the School until the new institution was in a financial position to erect buildings for its special use. 
Early in the summer of 1900 Henry Solon Graves, of the Division of Forestry, was appointed director of the new School, and the following Board of Governors organized the instruction and administration:

Arthur T. Hadley, LL.D., president.

Henry S. Graves, M.A., professor of forestry.

William $\mathrm{H}$. Brewer, $\mathrm{Ph} . \mathrm{D}$., professor of agriculture.

Gifford Pinchot, B.A., special lecturer on forest policy.

The School was fortunate in securing Mr. Graves as its first director, and its success is largely due to his foresight and counsels and to his high ideals of education in this comparatively new field.

Following the announcement of the School a circular was issued outlining the plan and the proposed courses of study. In June James W. Toumey, of the Division of Forestry, was appointed assistant professor of forestry.

In the organization of the School it was realized that from the standpoint of technical training two classes of men were required to successfully carry on the work in forestry in the United States. First, men trained in the broad field of technical forestry, competent to organize and administer forest property and conduct scientific investigations. Second, men especially skilled in the conduct of woods work and fitted for rangers, inspectors and foremen. In order to prepare men for the former, the Forest School was made a graduate department of the University. A summer school was maintained for several years at Milford. Entrance examinations were not required and certificates of attendance were issued at the expiration of the eight weeks' course. Because of the opportunity that it would give school teachers to become familiar with the methods of field work, particularly in silviculture and dendrology, the course was at first opened to women.

The Faculty included but one professor of forestry and one assistant professor. The remainder of the teaching staff was from the other departments of the University. Their work was supplemented by courses of special lectures by Gifford Pinchot and Frederick H. Newell.

A two-year course of study was prescribed, the terms coinciding with those of the other departments of the University. 
Entrance requirements were much more liberal than at present. Graduates of universities, colleges and scientific schools of high standing were accepted without examination, provided they could show requisite knowledge of botany, geology and chemistry. Others were required to pass examinations in mathematics, botany, geology, chemistry, physics, German or French, English and political economy. Special students were admitted without examination when they were able to present other evidence of their fitness to pursue the courses given. The tuition charges were one hundred dollars per year.

Looking back from a perspective of thirteen years the curriculum is simple in the extreme, and may be characterized by the emphasis placed upon courses in botany, geology and zoölogy, and the comparatively limited work in technical forestry. The forestry subjects in the curriculum were as follows: outline of forestry, silviculture, forest management, forest measurements, forest technology, lumbering, forest protection, forest history, forest administration and state and National forestry. With the exception of one short course of six lectures given by Gifford Pinchot the entire field was covered by the director and the assistant professor.

Provision was made for field work at New Haven, Milford and in the Adirondack Mountains. In the first announcement of the courses, field work was only briefly mentioned as follows: "Frequent excursions will be taken to points of interest near New Haven. In the spring of the second year the work will be transferred from New Haven to the field, the first few weeks being spent in Pennsylvania and the remaining time in the Adirondacks."

\section{I900-I90I}

The first term of the regular course began on Thursday, September 27, I900. Seven students were enrolled and remained to complete the two years' course, and in addition thirteen Academic and two Sheffield students attended one or more courses. The director and four of the regular students lived in Marsh Hall, which was provided by the University for the use of the School. In November, 1900, the first annual catalogue of the School was published, and included practically the same 
subject matter as the preliminary announcement. There was a more detailed account of the field work, and a list of the seven students in attendance.

During the year the School received in gifts to its equipment a splendid collection of axes and a large number of wood-working tools from W. D. Simmons of St. Louis, Mo., and a valuable collection of saws from H. C. Atkins of Indianapolis, Ind. Mr. Toumey gave his herbarium containing two thousand five hundred species of indigenous trees and shrubs to the School. The library was enlarged through the gift of three hundred and twenty-five volumes from Gifford Pinchot.

\section{I90I-I902}

Early in 1901 an illustrated circular announcing the Yale Summer School of Forestry was published. The course as planned, and later carried out, covered a period of eight weeks beginning July 8, r9or. No entrance examinations were required, but no one under seventeen years of age was admitted. The teaching staff consisted of the director and the assistant professor. The following courses were offered: introduction to forestry, silviculture, forest botany, forest measurements and forest protection. Twenty-seven students were enrolled, seven of whom were women. The latter had all the privileges of the School with the exception of living and boarding in camp.

At the opening of the regular course in Igor the previous year's class of seven members was augmented by three men from the Division of Forestry. The Junior class had a membership of twenty-one. The School was now for the first time in full operation, and the Faculty was called upon to give instruction in all the courses offered in the curriculum. In many respects, from the standpoint of instruction, it was the most critical period in the history of the School. With more than four times as many students as the previous year, and with the technical courses of the Senior year given for the first time, the burden of instruction was very great. The following courses were added: forest entomology, forest administration and law, and forest administration abroad.

During the second year the field work was more fully organized. A year before an agreement was made by the School 
and the New Haven Water Company whereby a portion of the forest property of the company was placed under the management of the School, thus making a large body of woodland near New Haven available for purposes of instruction and experiment. The field work in silviculture was chiefly confined to this tract. Arrangements were made for the Seniors to spend the last three weeks of the autumn term in lumber camps in northern New England.

After the Easter recess the work with the Senior class was transferred to Central Valley, N. Y., where the entire spring term was devoted to field work. A working plan was prepared for a forest of $I_{5}, 000$ acres owned by $\mathrm{E}$. H. Harriman of New York.

On the completion of their work, for the college year ending June, I902, the degree Master of Forestry was conferred upon eight members of the Senior class, and the first graduates of the School were ready to begin their professional careers in a field just beginning to develop rapidly in the United States. Soon after graduating, two members of the class, namely, Roy L. Marston ànd Alfred Akerman, were engaged as instructors.

$$
\text { I902-1903 }
$$

The second session of the summer school was under $\mathrm{Mr}$. Toumey, who was assisted by Walter Mulford, State Forester of Connecticut. Nineteen students were in attendance, of whom six were women. A large percentage of the male students were undergraduates from Eastern universities and colleges, nine of whom later entered the School for the regular two-year course.

The curriculum was greatly extended and the courses rearranged during the third year. In September, I902, Alfred Akerman and Roy L. Marston began their work as instructors. The position of assistant in botany, occupied the previous year by C. E. Preston, was filled by Arthur H. Graves. Howard S. Betts was appointed assistant in the wood testing laboratory, and Herman von Schrenk lecturer on diseases of trees to take the position formerly occupied by William C. Sturgis.

At the opening of the term twenty-six men enrolled in the entering class. Heretofore the students had been largely drawn 
from the Eastern states. In this class, however, all parts of the United States were represented, and one student came from Japan. The National character of the School for the first time became apparent in its student body. The course formerly given by $\mathrm{Mr}$. Verrill was given by Mr. Britton, State Entomologist of Connecticut. The courses in introduction to forestry and history of forestry were taken by Mr. Akerman, who also assisted Director Graves in the work in silviculture. The courses in lumbering and forest protection were taken by Mr. Marston, who also assisted Director Graves in forest management. The work in engineering was extended. Field surveying was given by Mr. Tracy, and a new course in forest engineering was under Mr. Marston. Through the generosity of George $\mathrm{H}$. Myers, M.F. '02, three thousand dollars was received to pay for the equipment of a laboratory in forest technology, and instruction in timber testing was given by Mr. Betts. Through coöperation with the Division of Forestry the laboratory was opened for investigation on the mechanical properties of wood.

In the early winter (December, 1902) the members of the Senior class were located in lumber camps in Maine, New Hampshire, New York, Michigan, Pennsylvania, North Carolina, Florida and Texas. Each student prepared a detailed report on lumbering in the region studied. The spring field work with the Senior class was at West Point Military Reservation, where a study was made of a large hardwood tract east of the Hudson River. The area was mapped and a working plan made under which it has since been managed.

There was a large increase in attendance, the registration in the regular course being forty-four students compared with thirty-three the previous year. They represented twenty-three collegiate institutions in fifteen states.

The endowment of the School was increased through the gift of fifty thousand dollars by Mrs. J. W. Pinchot and Gifford Pinchot. This gift enabled the Governing Board very materially to modify the courses of study, add a summer term to the regular course, and greatly increase the field work. The principal additions to the equipment of the School were through the purchase of a portion of the technical library of the late Charles Mohr. 


\section{3-1904}

The third session of the summer school, which opened on July I, I903, was reduced to seven weeks. Mr. Marston was in charge. The curriculum remained unchanged with the exception of greater diversity in the work, due to the larger number of special lectures. Fifteen students were in attendance, none of whom were women. Of those in attendance seven later entered the regular course. Mr. Akerman resigned at the close of the collegiate year in June and accepted the position of State Forester of Massachusetts.

The registration in the regular course was sixty-six, representing thirty-three collegiate institutions in twenty-three states. There was one student each from the Philippine Islands and Sweden. The large increase in students in the Senior class was partly due to the discontinuance of the College of Forestry at Cornell University. Special arrangements were made whereby students from that institution were admitted to the Yale Forest School, and ten men availed themselves of this arrangement.

Although no additions were made to the list of regular instructors, it became necessary to employ a number of temporary assistants because of the unexpectedly large number of students. Walter Mulford was employed to assist in the courses in silviculture and forest mensuration, and Austin Cary in the field work of the Senior class at Milford. Harry Tiemann, M.F. 'o3, was appointed engineer in the technological laboratory in the place of H. S. Betts, and continued in this position until 1909, when work in coöperation with the United States Government was discontinued.

In late December a disastrous fire broke out in Marsh Hall. It started in the basement and burned or severely injured the testing laboratory, the assembly hall, two recitation rooms and the instrument room. The School records, the library and herbarium were saved. For two weeks at the beginning of the winter term recitations and lectures were held at the Sheffield Scientific School. The restored building was in many respects better adapted to the requirements of the School than before the fire. The equipment at the summer school was greatly improved by the construction of three buildings which were the gift of Mr. and Mrs. James W. Pinchot. Through the further 
generosity of George $\mathrm{H}$. Myers the forest library of the late Dr. Robert Hartig was purchased and donated to the School. This collection contained fifteen hundred books and pamphlets representing the accumulation of many years. It is particularly rich in German periodicals and early books and pamphlets on forestry, many of which are long out of print and difficult to obtain.

For the first time the spring field work of the regular course was conducted at Milford, with Mr. Marston and Austin Cary, instructors. It later became apparent that it would be necessary to rearrange the curriculum and increase the amount of field work in order to realize more fully the object of instruction. During the winter an announcement was published of proposed changes in the curriculum. Experience had shown that the courses in forest mensuration and silviculture could not be satisfactorily taught without more field work. It became necessary to add to the Junior year a term wholly devoted to field work. Accordingly, the Junior year in 1904 opened at Milford at the same time as the summer school.

Heretofore the tuition for the Junior and Senior years was one hundred dollars each. Beginning in July, 1904, it was raised to one hundred and fifty dollars for the Junior year, and a year later to one hundred and twenty-five dollars for the Senior year. To the present no further changes in tuition charges have been made.

Thereafter the Junior class met at the School camp at Milford with the summer school students. The field and classroom work of the two classes, however, were wholly distinct and usually under separate instructors. The session of the summer school was seven weeks as in the previous year, but the regular term continued three weeks longer. Two distinct bodies of students tented in the same encampment and dined together, but the character of the instruction was necessarily wholly different.

$$
\text { 1904-1905 }
$$

Under this new arrangement the Junior courses in the summer of 1904 were given by Director Graves, assisted by E. E. Carter, M.F. '04. Mr. Toumey was assisted by A. H. Graves in carrying the work of the summer school. The work with 


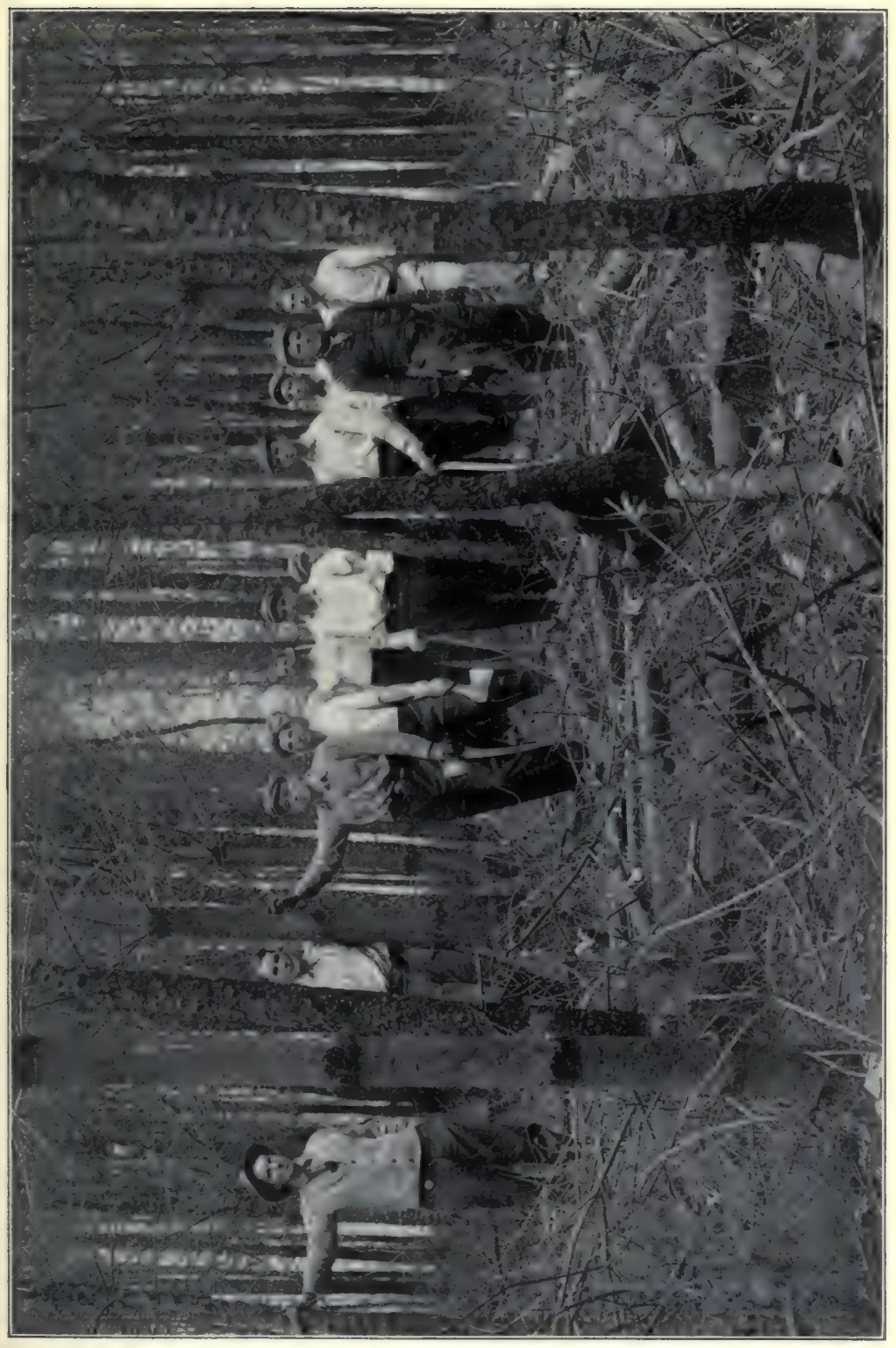

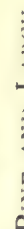

a

3

.

0

是 

the Juniors was confined to the following courses: foundation of silviculture, treatment of woodlands and forest mensuration. Thirty-four men were enrolled in the Junior class and eighteen in the summer school.

The experiment of shifting a large part of the field work to an extra summer term proved successful. At the opening of the autumn term at New Haven the total attendance was sixty-three exclusive of those from other departments.

The next year surveying was transferred to the summer term. On January 2, 1905, both the Junior and Senior classes met in Washington, D. C., to attend the Forest Congress. For one week the students attended the sessions of the Congress and the following week a series of specially arranged addresses and lectures to which students from other schools were also invited.

The Forest Club, composed of Faculty and students, was organized and has continued to meet on alternate Wednesday evenings except in the summer term. During the early winter a. group of Seniors with a smaller number of Juniors met and organized the Robin Hood Society of Foresters. After an existence of six years the organization was discontinued. The accumulated funds in the treasury of the society to the extent of more than five hundred dollars were contributed to the Graduates Fund of the School.

Shortly after the opening of the winter term Director Graves was commissioned by the Forest Service to visit India and the Philippine Islands to secure information relative to educational instruction in forestry that would best fit students for the practice of forestry in tropical regions and particularly in the Philippine Islands. During the six months of Director Graves' absence $\mathrm{Mr}$. Toumey was acting director, and B. E. Fernow, the former director of the New York State College of Forestry, conducted some of the courses. A. F. Hawes, M.F. 'o3, State Forester of Connecticut, also assisted in instruction.

As in the previous year, after the Easter recess, the work with the Senior class was transferred to the School camp at Milford. It became apparent, however, that it was unwise to continue the spring field work at this place since the men were already thoroughly familiar with the region. It seemed desirable that a wholly new field be selected for the spring work 
where lumbering operations were in progress and where conditions were better suited for the preparation of forest maps, the projection of logging roads, the estimating of timber and the making of working plans. Since the spring of 1905 it has been conducted on large tracts of virgin timber in the South.

The most important addition to the collections of the School during the year was a large assortment of forest products from the St. Louis Exposition. A former collection of exotic woods from the Buffalo Exposition had been severely damaged the year before in the fire at the School. The material from St. Louis and much besides is stored because of lack of space for display. As soon as a School building is erected this material can be arranged and made available for exhibition and purposes of instruction.

As in former years the majority of the twenty-nine members of the graduating class entered the Forest Service. The rapid expansion of the work of the Government under the direction of Gifford Pinchot gave opportunity for all who desired to begin the practice of their profession on the National Forests, which had been only recently transferred from the Department of the Interior to the Department of Agriculture and placed directly under the management of the Forest Service.

\section{5-1906}

The year beginning July, 1905, was the most satisfactory from the standpoint of the curriculum since the organization of the School. The instruction was made more efficient and foundations were laid for still further improvements the following year. The important change in the engineering courses became effective at the opening of the summer term. The course was conducted by J. C. Tracy, assisted by C. S. Farnham and W. L. Ulrich. For the first time a course in field dendrology was included in the summer work. Since 1905 there have been no marked changes in the courses as given at Milford. Only three courses are offered; namely, surveying, forest mensuration and field dendrology. Among the thirty-six men enrolled in the regular course were students from Canada, Norway, Sandwich Islands and South Africa. Eighteen attended the summer school, five of whom later entered the regular course. 
Herman H. Chapman, M.F. 'O4, of the Forest Service, was employed as assistant during the winter and spring terms. A course in State Forest law was given during the winter by Mr. Chapman. In April Mr. Marston resigned to enter the lumber business in Maine, and the field work in lumbering as formerly conducted by locating the students in lumber camps for a period of three weeks after the Thanksgiving recess was abandoned. The Senior field work of the spring term was conducted at Waterville, N. H., on a tract of 22,000 acres owned by the International Paper Company. The topographic work was under the direction of Henry Gannett, geographer of the United States Geological Survey. The forest work was conducted by Mr. Chapman.

The field work in silviculture was better organized, the autumn term being devoted to silvical excursions and investigations in the woods about New Haven and the remainder of the year to thinnings, improvement cuttings, nursery work, seeding and planting.

The importance of lumbering as a part of the curriculum was recognized by the National Lumber Manufacturers' Association at their annual meeting in 1905, and they voted to raise a fund to endow a chair of lumbering. Sixty thousand dollars was immediately pledged, and in the autumn turned over to the treasurer of the University, and in I9Io an additional forty thousand dollars was received. This fund has been of great value to the School as it made possible the appointment of R. C. Bryant of the Forest Service to take charge of the work in lumbering. Mr. Bryant began his work in September, I906.

During the year an Advisory Board was appointed from the graduates and proved very important in furthering the interests of the School and bringing the alumni into closer touch with its activities. The members of the first Advisory Board were G. H. Myers, M.F. '02, J. G. Peters, M.F. 'o3, and W. B. Greeley, M.F. '04.

\section{6-1907}

The year 1906 marked a long step forward in improving the curriculum. This was made possible through the addition to 
the Faculty of three instructors in forestry, namely Messrs. Chapman, Bryant and Hawley, each of whom was given a definite line of work which they have been pursuing and strengthening up to the present time. This marks a definite stage in the development of the curriculum because it is the beginning of the separation of the work into specific courses continuously handled by the same instructors. It gave an opportunity for the courses to develop and expand with succeeding years. Hitherto the lack of funds and available instructors of experience prevented the development of a Faculty adequate for the constantly increasing work of the School. The work of instruction as then organized was conducted by three groups of men: first, the regular Faculty, consisting of five resident members whose time was wholly given to the School and who conducted the technical courses in forestry; second, members of other departments of the University who gave specially arranged courses in auxiliary subjects; third, non-resident, special lecturers.

An important feature of the year was the development of the course in lumbering under Mr. Bryant. The work was organized with the advice of a committee from the National Lumber Manufacturers' Association. This advisory committee consisted of Nelson W. McLeod and Clifford I. Millard of St. Louis and Frederick E. Weyerhaeuser of St. Paul. The lectures in this subject were given by Mr. Bryant assisted by the members of the committee as special lecturers. Through the generosity of J. B. White the plant of the Missouri Lumber \& Mining Company in southern Missouri was placed at the disposal of the School for the spring work of the Senior class. The work in the woods was conducted by $\mathrm{Mr}$. Chapman, who was assisted in the topographic work by Henry Gannett of the United States Geological Survey. Mr. Bryant had charge of the work relating directly to lumbering. This proved so successful that the field work of the Senior class has since followed the same general plan.

$$
1907-1908
$$

The increased demand for foresters by the National government, by states, and by private owners of woodland, resulted in the rapid development of facilities for instruction. As early 
as 1907 seventeen institutions in the United States and Canada were offering instruction in forestry and five institutions had fully organized departments or schools for high-grade training. The standard required for the profession of forestry was becoming higher each year and already many of the graduates of minor schools found it difficult to find remunerative positions.

Six classes had now graduated with a total enrollment of 127. This does not include 37 men who did not take the full course. The occupations of the 127 graduates of the first six classes, in July, 1907, is shown in the following table:

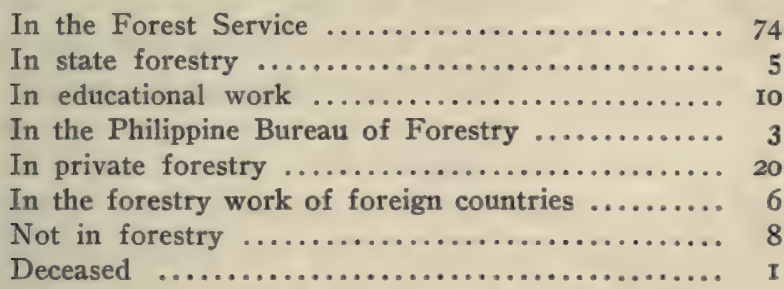

Hitherto there had been but one program of study prescribed for all students. All subjects in the regular course were required for the degree. A greater number of students were each year applying for admittance with advanced standing, having already had courses in technical forestry in other institutions. To supply this demand a number of advanced courses in forest technology, silviculture, lumbering and forest management were offered for the first time.

The spring work of the Senior class was conducted in Alabama on a tract of virgin forest owned by the Kaul Lumber Company. Hitherto nearly all the field work at New Haven was at Maltby Park, a comparatively small portion of the lands owned by the New Haven Water Company. During this year Mr. Hawley was employed as consulting forester for the company. Under this arrangement the School obtained the privilege of conducting field work on all the lands owned by the company, aggregating eight thousand acres, of which more than one-half is covered with forest, under an organized system of management. The open land is gradually being planted. This large tract of permanent forest near New Haven and within easy 
reach of the School is yearly becoming of greater importance for purposes of instruction.

With the decrease in the number of special lectures in the regular course, the Forest Club has been the avenue through which foresters and other scientific men visiting New Haven have been introduced to the School.

At the close of the work of the Senior class at New Haven in February, 1908, formal exercises were held for the first time. The principal address was by Gifford Pinchot. Other speakers were President Hadley, the Director of the School, W. B. Greeley and H. R. MacMillan, the latter representing the graduating class. These exercises continue to be held each year at New Haven before the Senior class leaves for the South.

$$
\text { 1908-1909 }
$$

In $1908 \mathrm{R}$. C. Bryant and R. C. Hawley were promoted to the rank of assistant professors. It was becoming more and more apparent, in order to meet the needs of technical instruction, that it would be necessary to lengthen the course to three years or else increase the requirements for admission. The latter course was followed. Early in the year a circular was issued announcing that candidates for admission for the degree Master of Forestry, in addition to completing an undergraduate college course, must have pursued certain specified subjects. The new requirements did not go into effect for two years in order that undergraduates then preparing for the School could arrange to cover the required work. Arrangements had been made with the Sheffield Scientific School whereby students in that institution, by taking certain studies in the Forest School during the last year of their undergraduate course, could complete the work at the Forest School in one year. With the gradual extension of the curriculum and the increase in the number of required subjects, this arrangement became more and more difficult. Through action of the Governing Board the old arrangement was discontinued, to go into effect at the opening of the school year I9I0.

The field work of the Senior class was conducted at Doucette, Tyler County, Texas, on the lands of the Thompson Brothers Lumber Company. The New Haven Water Company began 
the extensive planting of waste areas. Nurseries were established and plans made to reforest by planting during the next decade from I,500 to 2,000 acres of open land. The work on the forested areas was progressing rapidly and already there were many instructive illustrations of the results of applied forestry.

\section{9-1910}

The tenth class to enroll at the School entered in July, I909. There had been a gradual increase in attendance since the organization of the School. From seven students in 1900 the number had increased in 1909 to thirty-seven in the Senior class and forty-five in the Junior, not including five enrolled for the summer term only. In addition to the regular students fifteen were enrolled in the short course and twelve from other departments of the University.

This year marked the discontinuance of the summer school. The rapid development of secondary forest schools and departments of forestry in various institutions lessened somewhat the demand for this course. Furthermore the large increase in the number of students in the regular course made it difficult to provide instructors from among the members of the Faculty. During the existence of the summer school there were enrolled a total of 159 students or a yearly average of 18 .

S. J. Record was appointed instructor in forestry early in the year and W. O. Filley field assistant. In January the School suffered a distinct loss in the indefinite leave of absence granted the director on his appointment by President Taft to the position of Forester of the United States Forest Service. Mr. Toumey became acting director. The Senior field work was conducted at Clarks, La., on the property of the Central Louisiana Lumber Company.

The large increase in attendance called for more space for laboratories and lecture rooms. Marsh Hall was overcrowded, making it necessary to duplicate certain courses. As there was no prospect of a new building suitable for the needs of the School, the timber testing laboratory, only used for a few months each year, was dismantled to make space for more imperative needs. 
Early in the year Mrs. Morris K. Jesup of New York gave an endowment of $\$ 100,000$ for a professorship of silviculture, and $\mathrm{Mr}$. Toumey was appointed the Morris $\mathrm{K}$. Jesup professor of silviculture.

\section{I9IO-I9II}

At the opening of the summer term in I9Io it became apparent that an increasing number of men were being drawn from other institutions where forestry was taught. During the year five graduates in forestry from other schools were in attendance. Twenty-six states and foreign countries were represented in the student body, which was the same as in the previous year. No change in the distribution of the student body, due to the rapid development of forest schools and departments of forestry elsewhere in the country, was apparent. With the beginning of the year the curriculum was rearranged and all the courses became technical in character. The following changes were made in the teaching staff: Messrs. Chapman and Bryant were made full professors, S. J. Record was promoted to be assistant professor and W. O. Filley resigned and accepted the position of assistant forester of Connecticut.

The Senior field work was conducted at Trinity, Texas. The unusually large class made it necessary to employ two temporary field assistants, C. A. Hoar, M.F. 'Io, and Harold Fay, M.F. 'Io.

Nearly three years previous the task of increasing the resources of the School by five hundred thousand dollars was undertaken. The large increase in the number of students made the need of a new building almost imperative. Money was needed for salary increases and for experimental work and publications. At the close of the year the total receipts toward this fund were two hundred and fifty thousand dollars. At the end of the year forty-three men completed the course and received the degree Master of Forestry. This is the largest number that received the degree in a single year since the organization of the School.

$$
\text { I9II-I9I2 }
$$

For the past two years the requirements for admission were given considerable attention. In the curriculum as first formed there were many botanical, zoölogical and other courses which 


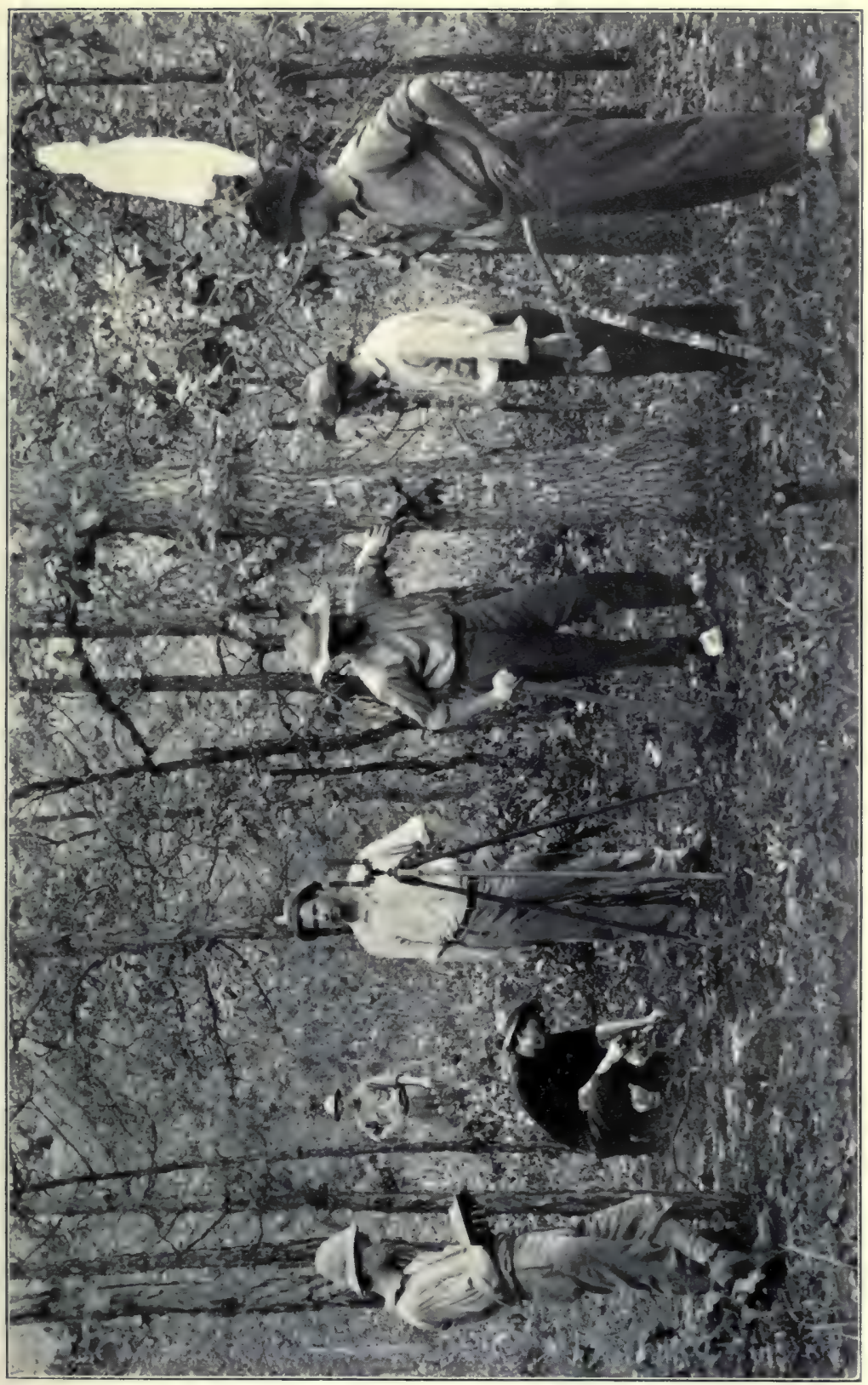

年 

in their scope paralleled the undergraduate work in colleges and universities. These subjects were deemed necessary because most applicants were poorly prepared in them, and it appeared advisable to incorporate them in the requirements for admission. The applicant must now hold a degree from a high-grade university, college or technical school and in addition present evidence that he has taken at least one full year in college or university botany, including general morphology, histology and physiology of plants; at least one college course in zoölogy, physics, inorganic chemistry, geology, economics, mechanical drawing, the completion of mathematics through trigonometry, and has a reading knowledge of French or German.

The effect of this was apparent in the class that entered under the new requirements in I9II. It resulted in a marked advance in scholarship due to a more thorough preparation in the sciences which are a foundation for forestry. In most respects the first year's operation of the new schedule was highly satisfactory. The elimination of general science and most of the special lecture courses gave the much needed opportunity to increase the technical work. The requirements in both silviculture and management were nearly doubled. There was a sharp falling off in attendance, but to what extent it was due to this change is not known. It is believed to have been partly due to the rapid increase in the number of schools. The attendance for the year was sixty, a decrease of forty-two from that of the previous year. This made no appreciable difference in the wide distribution of the students, as the sixty men enrolled were from twenty-five states.

The revised schedule, calling for additional field work in silviculture, made it necessary for the Junior class to spend two weeks of the spring term in the Adirondack Mountains. As in previous years the Senior field work was conducted in the South. The Crossett Lumber Company, Crossett, Ark., granted the use of their property for this work.

The curriculum at this time offered instruction in thirty-six courses in forestry subjects, all of a technical nature. They varied in length from one to three terms with the exception of two short courses on special subjects by outside lecturers. It was apparent that the work could not be materially extended, 
without putting too great a burden on the students, unless some of the courses offered were elective. It was believed to be impossible to omit any of the required courses and still provide an all-round training in technical forestry.

Because of the continued absence of Mr. Graves his resignation as director was accepted and Mr. Toumey, who had served as acting director for two years, was made director. Mr. Graves retained his position as a member of the Governing Board and of the Faculty, with leave extended for another year. Arrangements were completed whereby Mr. Record, beginning with the year I9I2-I3, would carry the work in technology formerly given by $\mathrm{Mr}$. Dean and the course on the classification and structure of wood formerly given by A. H. Graves.

For the first time since the organization of the School the library was placed in charge of a trained librarian, Miss I. M. Tisdale, formerly on the staff of the University Library. The library had grown to such proportions that this was necessary in order to properly catalogue and put it in form for ready reference and greater usefulness.

The publication of a series of bulletins, memoirs and miscellaneous works relating to the School was begun. This was of vast importance as it gave the School a wider field of usefulness and brought it in closer touch with the alumni and the general public.

A graduate Advisory Board had been elected in 1905 in order to bring the School into closer relations with the alumni. At first it had consisted of but three members, but was later enlarged to five, and has been of continually increasing usefulness. During this year the School was brought into closer relations with the alumni through the organization of the alumni association with officers and class secretaries. This association met at New Haven on December 20 and 2I, I9II, and the following officers were elected for five years:

President, W. B. Greeley, M.F. '04.

Vice-president, T. S. Woolsey, Jr., M.F. '03.

Secretary and treasurer, H. H. Chapman, M.F. '04.

This association not only afforded an opportunity for the organization of the alumni into an effective body and familiarized them with the progress of the School, but it served as a 
stimulus to permanently establish a graduates' fund. The subscriptions to this fund during the first meeting of the association were more than four thousand dollars. A gift of one thousand dollars was received from William Wheeler of Buffalo, N. Y., the income to be given yearly as a prize for meritorious work in silviculture.

The first number of the series of bulletins and memoirs published by the School was issued in February, I9I2. This is "A Classification for Forestry Literature" and is the classification used in the School library. In February, I9I2, the report of the alumni reunion was published and distributed. Two important manuals dealing with forestry subjects were published by members of the Faculty during the year, namely: "Forestry in New England" by Mr. Hawley, in collaboration with Mr. Hawes, State Forester of Vermont, and "Identification of the Economic Woods of the United States" by Mr. Record.

A conference of American Forest Schools was called in December, I909, to consider the aim, scope, grade and length of curriculum as the first step in the standardization of forestry education. At this conference a committee was appointed to draw up a plan for the standardization of the requirements for technical training in forestry. Director Graves was appointed chairman; other members of the committee were B. E. Fernow, R. T. Fisher, Filibert Roth and Gifford Pinchot. A second conference was called in December, I9II. Nearly all American institutions offering instruction in forestry were represented. The plan of the committee was discussed in detail and it was agreed to publish the report in the Forestry Quarterly. The committee was continued, and on the resignation of the chairman his place was taken by Mr. Toumey. The report of the committee was published in Volume X, Number 3, of the Forestry Quarterly, and widely distributed. The importance of this report, its influence on forestry education in America, and the part taken in it by the Yale Forest School, calls for its recognition in this historical sketch.

\section{I9I2-I9I3}

The total number of students enrolled during the year was fifty. It became still more evident that the marked falling off 
in attendance, first noticeable in the previous year's class and still more conspicuous in the enrollment for the year 1912-13, was due to two fundamental causes: first, the continued increase in the facilities for forestry education in the United States; second, the keener competition for profitable employment after graduation. To what extent these conditions will affect future attendance at the school it is uncertain. Future classes are likely to be smaller and to include a constantly increasing number of students from other schools who come to Yale to complete their technical training.

Shortly after the organization of the alumni association in December, I9II, a movement was set on foot to publish a quarterly to be known as the Yale Forest School News. The graduate Advisory Board undertook the financing and management of the proposed publication. The first number of this new quarterly appeared in January, 1913, with the following officers in charge:

Editor, W. B. Greeley, M.F. '04.

Alumni notes, H. H. Chapman, M.F. 'o4.

Managing editor, S. J. Record, M.F. '05.

The Yale Forest School Neres was well received from the first. It serves a much needed purpose as a medium for communication between the alumni and the officers of instruction.

Bulletin 2, "Prolonging the Cut of Southern Pine," by Messrs. Chapman and Bryant, was published in February, 19I3.

The field work of the Senior class was conducted at Warren, Ark., and the spring field work of the Junior class in the Adirondack Mountains.

In June, I913, six hundred and twenty-five acres of land at Keene, N. H., were presented to the School by George H. Myers, M.F. 'o2, as the nucleus for a School forest.

\section{OUTLOOK FOR THE FUTURE}

This historical sketch of the development of the Yale Forest School from its organization until the close of the school year in June, 1913, would not be complete without a brief statement relating to its outlook for the future. As stated in the address 
of the director before the alumni in December, I9II, the future development of the School must be along the following lines:

a. In adding to the efficiency of the present courses;

b. In establishing elective courses in the Senior year;

c. In increasing our facilities for research and advanced work.

The need of the first of these is always present because no course is so complete that it does not require constant attention on the part of the instructor in order to keep it abreast of the times and effective from an educational standpoint.

As regards the second, it is believed that the time is already at hand when elective courses should be considered. Because of the large amount of required work it is not possible to add many optional courses, such as the course on park and street trees offered for the first time in I9II, and four proposed optional courses to be given for the first time in 1913-I4. Additional courses must be largely elective in the Senior year, substituted for some of those required at the present time.

Forestry is a very broad and diversified subject. The training required for work in one particular branch may be quite different from that required in another. Thus a man who devotes himself to the reproduction, development and growth of timber should specialize in silviculture and management, while one whose chief attention is given to utilization should specialize in lumbering and technology.

Regarding the third, it is useless to offer advanced work unless there are students prepared to take it. In general, such work is only open to those who have already completed the regular course or what is deemed equivalent in other institutions. Fellowships are needed to stimulate advanced work and to induce able men to come to Yale and continue along some particular line in forestry.

With the expanded work of the school it is possible that the best interests of the profession can be served by opening certain courses to men with woods experience who are not college or university graduates, but who desire to enter the School as special students in order to secure instruction along some particular line. 
The Treasurer's reports for the past twelve years show the yearly income from tuition and from endowment to be as follows:

\begin{tabular}{|c|c|c|c|}
\hline & & $\begin{array}{l}\text { ncome from } \\
\text { Tuition }\end{array}$ & $\begin{array}{l}\text { Income from } \\
\text { Endowment }\end{array}$ \\
\hline 1900 & $\ldots \ldots \ldots \ldots \ldots \ldots \ldots \ldots \ldots$ & & $\$ 861.52$ \\
\hline 1901 & ........................ $\$$ & $\$ 1,240.00$ & $6,666.80$ \\
\hline 1902 & 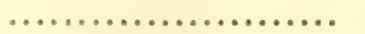 & $3,373.84$ & $7,351.05$ \\
\hline 1903 & ....................... & $4,585.32$ & $7,224.71$ \\
\hline 1904 & n..................... & $6,859.5 \mathrm{I}$ & $8,902.42$ \\
\hline 1905 & 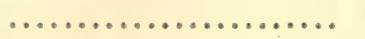 & $5,997.50$ & $8,568.95$ \\
\hline 1906 & n...................... & $6,026.34$ & $7,951.66$ \\
\hline r907 & n...................... & $6,469.34$ & $9,507.89$ \\
\hline 1908 & & $7,269.41$ & $10,057.62$ \\
\hline 1909 & n...................... & $8,085.24$ & $10,811.47$ \\
\hline I910 & ...................... & II,681.39 & $12,280.22$ \\
\hline I9II & 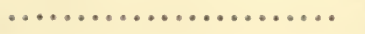 & I1,720.50 & 17,701.74 \\
\hline 1912 & 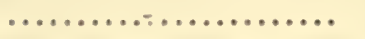 & $7,765.76$ & $20,706.40$ \\
\hline
\end{tabular}

From this table it appears that the increase in annual income is from both tuition and endowment. With our student body approximately the same in numbers as now, our present endowment will carry the work of the School as now conducted and provide for minor extensions, particularly in the direction of publications. It will not, however, entirely provide for necessary increases in the salaries of the younger members of the Faculty which must be met in the immediate future, or for the extension of the curriculum and the advancement of the School along the various lines already begun or that have been suggested.

With the smaller classes of the past two years Marsh Hall as now arranged provides, sufficient space for necessary lecture rooms, but laboratory facilities are insufficient, the library is overcrowded and there is no space for the display of collections.

The work accomplished by the School is expressed in the biographical records of her alumni which appear in this volume. These records clearly show to what extent Yale men are identified with and are responsible for the development of forestry in America. 


\section{BIOGRAPHIES}





\title{
BIOGRAPHIES
}

\author{
CLASS OF 1902 \\ Graduates holding Degree of M.F.
}

\section{Alfred Akerman}

\author{
Athens, Ga.†
}

Alfred Akerman was born July 3, I876, in Cartersville, Ga., the son of Amos Tappan Akerman, district attorney and attorney general of the United States, and Martha Rebecca (Galloway) Akerman. $\mathrm{He}$ is the grandson on his father's side of Benjamin Akerman and Olive (Melvin) Akerman, and on his mother's side of Samuel Galloway and Elizabeth (Scudder) Galloway. He has six brothers: Benjamin Akerman, Walter Akerman, Alexander Akerman, Joseph Akerman, B.A. Franklin College, University of Georgia '94, and M.D. Johns Hopkins 'oo, Charles Akerman, B.A. Franklin College, University of Georgia, and B.L. University of Georgia, and Clement Akerman, B.A. Franklin College, University of Georgia.

He was prepared at Cartersville High School and received the degree of B.A. from Franklin College, University of Georgia, in 1898. Before entering the Yale Forest School he studied at Berlin and Tuebingen. $\mathrm{He}$ was employed at different times as a reporter, a bank clerk and clerk for a lumber concern.

He was married October 15, I902, in New Haven, Conn., to Miss Adeline Sophia Brown of New Haven, Conn., daughter of John Hallock Brown and Sophia (Price) Brown. They have three daughters: Catherine Akerman, born August 6, 1903, in New Haven, Conn.; Ruth Akerman, born January 24, 1905, in Cambridge, Mass.; Elfreda Akerman, born February I, 1907, in Athens, Ga., and two sons: Robert Akerman, born November 25, I908, in Athens, Ga., and Nigel Akerman, born October 29, 1910, in Athens, Ga.

Akerman is professor of forestry at the University of Georgia. After graduating from the Yale Forest School, he held the positions successively of instructor at the Yale Forest School, forest assistant in the United States Forest Service, state forester of Connecticut, and state forester of Massachusetts. He has occupied his present position since July I, I906.

† The best permanent addresses are indicated by italics. 
$\mathrm{He}$ is a Presbyterian. In politics he is affiliated with the Democratic party. He served at one time in the state militia and is a member of the Society of American Foresters. $\mathrm{He}$ traveled in Germany in 1902.

He has published Bulletins I, 2, 3 and 5, Mass. Forester's Office, and several articles in Forest, Fish and Game.

\section{Charles S. Chapman}

Business address, 719 Yeon Building, Portland, Ore. Residence, Alexandra Court, Portland, Ore.

Charles Sidney Chapman was born April 2, 1880, in Westbrook, Conn., the son of Charles H. Chapman and Helen (Chalker) Chapman. His father served as an officer in the navy during the Civil War, and in the latter years of his life was engaged in farming. He has two sisters: Estella and Mary Chapman.

He was prepared in the public schools in Westbrook, Conn., and in 1898 was graduated with the degree of B.Agr. from Storrs (now Connecticut) Agricultural College.

$\mathrm{He}$ is unmarried.

Chapman is secretary and manager of the Oregon Forest Fire Association with headquarters at Portland, Ore. He was forest assistant in the United States Forest Service from 1902 to 1905 ; forester for the E. P. Burton Lumber Company at Charleston, S. C., from 1905 to 1907 ; inspector of timber sales in the Forest Service in 1907-08; chief of the office of organization and assistant forester, operation, in 1908-09; forester, District 6, Washington, Oregon and Alaska in r909-ro.

In politics Chapman is independent. $\mathrm{He}$ served as sergeant of the Third Connecticut Volunteer Infantry in the SpanishAmerican War, but was not sent out of the United States. He is a member of the Portland Press Club, the Portland Commercial Club, the Oregon Conservation Association, Society of American Foresters and the Masonic Order.

He has written: Working plan for forest lands in Berkeley County, S. C., Bull. U. S. Forest Service; numerous articles in Portland, Ore., papers for Sunday editions and in trade journals. He has delivered many addresses on forest subjects. 


\section{Alfred K. Chittenden}

Business address, Engineering Experiment Station, Urbana, Ill. Residence, Champaign, Ill.

Alfred Knight Chittenden was born October 28, 1879, in New Haven, Conn., the son of Professor Russell Henry Chittenden, Ph.D., Sc.D., LL.D., Yale '75 S., director of the Sheffield Scientific School, and Gertrude Louise (Baldwin) Chittenden. He has two sisters, Edith Russell Chittenden, B.A. Smith '99, and Lilla Millard (Chittenden) Barbour, wife of Henry Gray Barbour, B.A. Trinity 'o6, M.D. Johns Hopkins 'ro, who was appointed assistant professor of pharmacology in the Yale Medical School in 1912.

He was prepared at the Hopkins Grammar School of New Haven and graduated from the Sheffield Scientific School in 1900. In the Scientific School he took the Civil Engineer Course, received general scholastic honors, and was a member of the scholarship society, Sigma $\mathrm{Xi}$.

He was married February II, 1908, in Washington, D. C., to Miss Lulu W. Brower of Washington.

Chittenden is director of the engineering experiment station and lecturer on timber and timber resources at the College of Engineering of the University of Illinois. After graduation from the Forest School he went abroad for seven months to study forest conditions in Germany, Austria, Switzerland, France and England. On returning to the United States he entered the United States Forest Service and has since worked in nearly every state in the Union, serving successively as forest assistant, chief of the section of coöperation, assistant district forester and forest inspector. For a year, in 1907, he was in private business in Baltimore, doing consulting forestry work under the firm name of Chittenden \& Patterson. On September 20, I9II, he was appointed forester in the United States Indian Service with headquarters in Washington, D. C. This position he held until receiving his present appointment.

He writes: "The Indian Service has a well developed Forest Service which is handling all timber matters on the Indian Reservations. There are thirty-one saw mills on the reservations operated for the benefit of the Indians by the Government. These mills vary in size from small portable mills to the large mill, with a daily capacity of over 200,000 feet, on the Menominee Indian Reservation in Wisconsin. 
"The total area of Indian timber lands is roughly estimated at $6,500,000$ acres, containing approximately 38,000,000,000 feet of timber, and valued at over $\$ 84,000,000$. In order to protect and properly administer these resources a considerable force of men is employed, consisting of forest guards, rangers, scalers, lumbermen and technically trained foresters. The work is in many respects similar to that of the Forest Service, except that no purely investigative work is carried on and that where it seems advisable timber is logged, handled and manufactured by the Service, the lumber being sold or disposed of for the benefit of the Indians. A considerable amount of permanent improvement work is being carried on, roads, trails, telephone lines, cabins, corrals and fences being constructed. The Indian timber lands, unlike the National Forests, were not set aside for protective purposes, but for the use and benefit of the Indians. Much of the timber is located on good agricultural soil, some of which is allotted. In such cases clear cutting is practised, all the timber being cut and removed, and the Indians encouraged to farm this land. On the really forest soil, however, forestry methods are followed in logging."

He has published: Forest conditions in Northern New Hampshire, Bull. 55, U. S. Forest Service; The red gum, Bull. 58, U. S. Forest Service.

\section{George E. Clement}

\section{Warren Street, Boston, Mass.}

George Edwards Clement was born April 21, 1877, in Vienna, Austria, the son of George W. Clement.

He received the degree of B.A. from Harvard University in Igoo.

$\mathrm{He}$ is unmarried.

Clement is at present engaged in a study of the gypsy moth situation in New England, with particular reference to preventing its spread by silvicultural measures. This study is in coöperation between the Forest Service and the Bureau of Entomology. Besides his work in the Service he has been employed as forester for the Great Northern Paper Company and for Fisher \& Bryant, consulting foresters. 


\section{Temple Emmet}

Stony Brook, Long Island, N. Y.

Christopher Temple Emmet was born July 8, 1868, in Pelham, N. Y., the son of William Jenkins Emmet and Julia Colt (Pierson) Emmet. $\mathrm{He}$ is the grandson on his father's side of Robert Emmet and Rosina (Hubley) Emmet, and on his mother's side of Josiah G. Pierson and Julia (Colt) Pierson. He has four brothers: Robert Temple Emmet, a graduate of West Point; William LeRoy Emmet, a graduate of Annapolis; Devereux Emmet, B.A. Columbia '83 and LL.B. '85, and Richard Stockton Emmet; and three sisters: Rosina Emmet, Lydia Field Emmet and Jane Erin Emmet.

He was prepared at Bishops College School, Lennoxville, Quebec, Canada, and at the Stevens High School, and in 189 r graduated with the degree of M.E. from Stevens Institute of Technology.

He was married October 27, 1896, in Red Hook, N. Y., to Miss Alida Chanler, daughter of John Winthrop Chanler and Margaret (Astor) Chanler. They have four daughters: Elizabeth Winthrop Emmet, born September 8, 1897, in Newport, R. I.; Margaret Chanler Emmet, born April 10, 1899, in New York City; Hester Alida Emmet, born December 5, I90I, in New Haven, Conn., and Jane Erin Emmet, born May I6, 1908, in Freiburg, Baden, Germany; and three sons: Christopher Temple Emmet, Jr., born March 18, 1900, in Port Chester, N. Y.; Winthrop Stuyvesant Emmet, born September 4, 1910, in Freiburg, Baden, Germany, and William Patten Emmet, born July 26, 1911, in Freiburg, Baden, Germany. Another son, Egerton Chanler Emmet, was born March 9, 1907 , in Stony Brook, N. Y., and died December I8, 1907.

Emmet is engaged in farming at Stony Brook, Long Island.

$\mathrm{He}$ is an Episcopalian, and a member of the following societies: Academy of Sciences; American Geographical Society; National Geographic Society; New York Zoölogical Society; American Museum of Natural History; American Forestry Association; Metropolitan Museum of Art; Audubon Society; Knickerbocker Club; Racquet and Tennis Club and St. Anthony Club of New York; Tobique Salmon Club and Ore Hill Shooting Club.

\section{William C. Hodge, Jr.}

Business address, Forest Service, San Francisco, Calif.

Residence, 3240 Pacific Avenue, San Francisco, Calif.

William Churchill Hodge, Jr., was born October 24, 1877, in Buffalo, N. Y., the son of William Churchill Hodge and Helen Maria (Hopkins) 
Hodge. He is the grandson on his father's side of William Hodge of Buffalo, N. Y., son of William Hodge of Buffalo, N. Y., son of Benjamin Hodge of Connecticut. On his mother's side he is the grandson of Nelson K. Hopkins of Buffalo, N. Y. He has two brothers: Harold Hodge and Sheldon Hodge.

He was prepared at the Buffalo High School and at Phillips Andover Academy, and received the degree of B.A. at Yale in 1899 . He was a member of Psi Upsilon.

He is unmarried.

After graduation from the Forest School Hodge entered the United States Forest Service, remaining until 1908, when he became deputy state forester of California. In roro he reèntered the Government Service and after some time in the office of silviculture, where he made an exhaustive study of methods of reconnaissance now in use in District 5 , is now inspector of fire plans under operation, with headquarters in San Francisco.

$\mathrm{He}$ is Progressive in politics and is a member of the Society of American Foresters, the Century Club of Washington, D. C., and the University Club of San Francisco.

\section{Ralph S. Hosmer}

Business address, Box 207, Honolulu, Hawaii

Residence, 1054 King Street, Honolulu, Hawaii

Ralph S[heidon] Hosmer was born March 4, 1874, in Deerfield, Mass., the son of Rev. George Herbert Hosmer and Julia West (Sheldon) Hosmer. His father was minister of the Unitarian parishes of Deerfield, Bridgewater, Salem and Dorchester, Mass., president of the Unitarian Temperance Society and a member and officer in various educational and charitable organizations. $\mathrm{He}$ is a descendant of James Hosmer, one of the first settlers of Concord, Mass., and the grandson on his father's side of Rev. G. Washington Hosmer, D.D., and Hannah Poor (Kendall) Hosmer. His mother was the third daughter of William Sheldon and Catharine (Williams) Sheldon of Deerfield, Mass.

He studied at the Boston Latin School for two years and with private tutors, and from I89I to 1895 attended the Bussey Institution and Lawrence Scientific School of Harvard University. In 1894 he received the degree of B.A.S. from Harvard.

$\mathrm{He}$ is unmarried.

From May, I896, to November, I898, Hosmer was assistant in the division of soils, United States Department of Agriculture, 
Washington, D. C. He was chief of the section of forest replacement, Bureau of Forestry in 1903, and since December, 1903, has been collaborator of the Bureau of Forestry and Forest Service and superintendent of forestry in the territory of Hawaii under the Board of Commissioners of Agriculture and Forestry. His course in the Forest School at Yale was taken during a furlough, and at this time he also gave a course in forest mensuration at the Forest School. He was first treasurer of the Society of American Foresters from I90r to I903, a delegate from Hawaii to the Conference of the Governors in May, I908, and a delegate from Hawaii and speaker at the Seventeenth National Irrigation Congress at Spokane and at the First Conservation Congress at Seattle in I909. He has been a member of the Chemical Territorial Conservation Commission of Hawaii since 1908 and vice president of the Board of Regents, College of Hawaii, since 1907 .

Concerning his various experiences, Hosmer writes: "Summer of 1902 was spent in Maine, in charge of a party working near Moosehead Lake on study of spruce on cut-over land, carried on jointly by the Bureau of Forestry and the State of Maine. In the summer season of 1903 I went on an inspection trip to New England regarding work on white pine, in section of forest replacement, and from July to November I, I was in Southern California in charge in that part of the state of coöperative forest investigation carried on by the Bureau of Forestry and the State of California. Since January, I904, I have been in Hawaii; organized the division of forestry in the Board of Agriculture and Forestry; established forest reserve system; systematized forest fire service; conducted campaign of education in forestry and conservation; and pursued policy of advice and assistance to private owners, particularly in tree planting; also, as far as limited funds permitted, have carried on experimental work in the introduction into and trial in Hawaii of trees of economic importance new to the islands. Outside of my regular work I have been interested in the establishment of the College of Hawaii, the local college of agriculture and mechanic arts, of which $I$ have been a regent since its inception; and in various phases of city improvement work. My chief avocations are in connection with affairs of the Harvard Club of Hawaii 
and the local University Club. I have been much interested, and have helped as I could, in the establishment of the Volcanological Observatory at Kilauea, and in the extension to Hawaii of several branches of government scientific work carried on by various bureaus and departments. In 1906 I made a three months' trip to the Eastern states, during which $I$ read a paper, subsequently published in its Proceedings, before the Society of American Foresters. In 1908 I was again in the East, at the time of the Conference of the Governors, and in 1909 on the Pacific Coast, for the meetings of Spokane and Seattle."

Hosmer is a member of the Unitarian church. In politics he is an "independent Republican, with strong leanings toward Progressiveism." $\mathrm{He}$ is a member of the following associations: Society of American Foresters; Massachusetts, Pennsylvania, Canadian, Minnesota and American Forestry associations; National Conservation Association; Biological Society, Washington, D. C.; Hawaiian Historical Society; Social Science Society of Honolulu; University Club, Honolulu; Harvard Club of Hawaii (secretary); Harvard Club of Washington and several Alumni associations, including the Yale Club of Hawaii.

He has published: (With E. S. Bruce) A forest working plan for township 40, New York State Forest Preserve, Bull. 30, Div. of For., 190r; (With E. S. Bruce) A forest working plan for townships 5, 6 and $4 \mathrm{I}$, Rep. of For., Fish and Game Com. of N. Y., 1903; A study of spruce, on cut-over land, 4th Rep. For. Com. of Maine, 1902; Reports of the Division of Forestry, Ann. Reps. Bd. Coms. of Agric. and For., Hawaii, I904-10; Report as chairman of Conservation Commission of Hawaii, Ann. Rep. Div. For., 1908; various articles on forestry and conservation in Hawaiian Forester and Agriculturist, Honolulu, 1904-12; illustrated article in American Conservation, August, I9II, addresses before Society of American Foresters, 1906, National Irrigation Congress, 1909, Forest Conservation Congress, 1900, published in Proceedings of those associations.

\section{Roy L. Marston}

\section{Skowhegan, Maine}

Roy Leon Marston was born September 10, 1877, in Skowhegan, Maine, the son of Charles A. Marston, a representative and senator, and Sarah (Steward) Marston. On his father's side he is of Scotch, and 
on his mother's of English descent. His father's ancestors have been lumbermen for four generations. He has two sisters: Lola (Marston) Blunt, a graduate of Mills College, Calif., and Mary (Marston) Stewart, a graduate of Mrs. Smallwood's School; and two brothers: Coburn S. Marston, a graduate of Annapolis, and Clair R. Marston, a graduate of the Tome School for Boys, Fort Deposit, Md.

He was prepared at Bloomfield Academy and the Skowhegan High School and received the degree of B.A. from Bowdoin College in 1899 . He was in the lumber business for five years before entering the Yale Forest School.

He was married November 29, 1904, in New Haven, Conn., to Miss Julie Parmelee of New Haven, Conn., daughter of Mr. and Mrs. Henry S. Parmelee. They have no children.

Marston has been treasurer and manager of the Coburn Heirs, Inc., since December 26, I9Io. He taught at the Yale Forest School until April, 1906. He then became forester to the United States Military Academy. He was later made a member of the academic staff of the United States Military Academy and from I 905 to I9Io was a consulting forester. He was a member of the Tariff Board from I9Io to I9I2.

He writes: "Have worked professionally in New York, New Hampshire, Vermont, Florida, Pennsylvania, West Virginia, Oregon, Washington, California, Texas, Louisiana, Mississippi, Maine, Canada, Mexico, Korea and China in my private practice. Have had charge of all the work on the forest reservation of the United States Military Academy since 1902, in addition to some teaching, lecturing, landscape work and water supply work for the Academy. Made a trip to Hawaii, China, Japan and Korea for professional work in I908. Had charge of the investigation of the pulp industry, and the survey of available pulp material for the Tariff Board. Made a topographical map and working plan for 225,000 acres belonging to the estate of A. and P. Coburn in Maine, and thereupon organized Coburn Heirs, Inc., of which I am now manager. Have lectured on forestry subjects before Bowdoin College, University of Maine and various other organizations."

In politics Marston is a Republican. He was a delegate to the Republican State Convention in 1908, I910 and 1912, and Republican candidate for representative to the Legislature in 1912. He is a Mason, a member of the Loyal Order of Moose, 
the Society of American Foresters, the American Association of Science, the Milburn Club, the Graduates Club of New Haven, University Club of Boston, West Point Army Mess, the Grange and Patrons of Husbandry.

\section{George H. Myers}

Business address, 1509, 38 West Thirty-second Street, New York City Residence (Summer), Union, via R. D., Stafford Springs, Conn.

Residence (Winter), 2339 Massachusetts Avenue, Washington, D. C.

George Hewitt Myers was born September 10, 1875, in Cleveland, Ohio, the son of John J. Myers, first president of the Vermont Marble Company (died in 1883 , from injuries received in a runaway at Washington, D. C.), and Mary Butterfield Ware (Hewitt) Myers. He has one sister, Helen (Myers) Buchanan, wife of James A. Buchanan, and one brother, John Ripley Myers, B.A. Hamilton ' 87 . On his father's side he is of German, and on his mother's of Colonial descent.

He was prepared at the Hill School, Pottstown, Pa., and in 1898 was graduated from Yale College, where he received a second colloquy Senior appointment.

He was married April 21, I908, in Fall River, Mass., to Miss Louise Stoddard Chase of Fall River, daughter of Simeon Borden Chase, cotton manufacturer and banker, and Louise Whitman (Hills) Chase. They have one child, Persis Chase Myers, born February 16, 1909, at South Lancaster, Mass.

Myers has given more and more attention to business since leaving the Yale Forest School but continues to be slightly in touch with forestry through buying land in Connecticut and an interest in lumbering in the State of Washington.

In 1898-99 he studied botany and English at the Harvard Graduate School, and then traveled for a year, having his headquarters at Washington, D. C. During the three years following graduation from the Forest School, he was engaged in the United States Forest Service, also traveling extensively for the study of forests.

He was a member of the Graduate Advisory Board of the Yale Forest School, where he has given lectures on foreign forestry. He has traveled widely, as follows: 1896, western Europe; 1900, Porto Rico and Cuba; 1902, western United States; 1903, France, Germany, Austria and Switzerland; 1905, 
visited forests of India, Philippines, and Japan, with Professor Graves of Yale; 1908, Alaska; also, the Pacific coast about once a year, mostly on business.

$\mathrm{He}$ is a "Progressive, non-Rooseveltian Republican," and is a member of the Metropolitan, Riding and Hunt, and Chevy Chase clubs of Washington, D. C. 


\title{
CLASS OF 1903 \\ Graduates holding Degree of M.F.
}

\author{
John B. Anderson
}

Black Mountain, N.C.

John Bullions Anderson was born November 19, 1874, in Martin, Mich., the son of John Anderson, a minister of the Presbyterian church, and Mary B. (Gray) Anderson. On his father's side he is of Scotch-Irish, and on his mother's of English-Scotch ancestry. He has two sisters: Mrs. F. S. Goodman and Grace E. Anderson, who studied at Smith College, and two brothers: Harry G. Anderson, M.D. College of Physicians and Surgeons, Columbia University, 89 , and Charles G. Anderson.

$\mathrm{He}$ received the degree of $\mathrm{Ph} . \mathrm{B}$. at Union College in 1896 .

He was married February 3, 1904, in Albany, N. Y., to Miss Clara N. MacRoberts of Albany, N. Y., daughter of Robert MacRoberts and Emma (Hill) MacRoberts. They have one son, Robert B. Anderson, born May 29, I9I0, in Black Mountain, N. C., and one daughter, Grace E. Anderson, born March 15, 1912, in Black Mountain, N. C. Another daughter, Mary B. Anderson, born October 3I, 1904, in Albany, N. Y., died October 30, 1907 .

Anderson has been located for the last few years at Black Mountain, N. C., as manager of a sawmill and cannery. He is a Presbyterian, and in politics a Republican.

\section{Edward A. Braniff}

Business address, 616-618 R. A. Long Building, Kansas City, Mo.

Oklahoma City, Okla.

Edward Andrew Braniff was born May 4, 1876, in Houtzdale, Pa., the son of John A. Braniff and Mary Catherine (Baker) Braniff. On his father's side he is of English, Irish and German, and on his mother's of German ancestry. He has three brothers: Thomas E. Braniff, Paul Revere Braniff and Philip Braniff, and two sisters: Madeline Braniff and Mrs. H. G. Russell.

He was prepared at the Central High School, Kansas City, Mo., and before entering the Yale Forest School, was a newspaper writer for the Kansas City Star. 
He was married July 10, 1905, in New Haven, Conn., to Miss Elizabeth Conboy of New Haven, Conn., daughter of John Conboy. They have one daughter, Lisa Braniff, born July 20, 1906.

Braniff is manager of the department for Western Missouri, Oklahoma and Kansas, for the Fidelity \& Deposit Company of Maryland, dealers in casualty insurance and surety bonds. $\mathrm{He}$ was previously engaged as manager of the bond department of Merrell \& Braniff, a surety bond and liability insurance company.

$\mathrm{He}$ is a member of the Roman Catholic church and in politics is a Progressive.

\section{George L. Clothier \\ Business address, State College of Washington, Pullman, Wash. Home address, Paxico, Kans.}

George Lemon Clothier was born June 30, 1863, in Walkersville, W. Va., the son of Henderson Hall Clothier and Jane (Clark) Clothier. His grandfather, Samuel Clothier, was English and his grandmother, whose maiden name was Crawford, was Scotch. The Clothier family were strong advocates of the Union during the Civil War, and several served in the Union army. On his mother's side he is of German and English descent, his grandfather being George Bogarth Clark and his grandmother Matilda (Stone) Clark. The Clarks were also strong supporters of the Union during the Civil War. He has one sister, Mary Elizabeth (Clothier) Martin, M.D.; and three brothers: Samuel H. Clothier, M.D., Robert W. Clothier, M.S., and Nathan S. Clothier, D.D.S.

He received the degree of B.S. from the Kansas State Agricultural College in 1892 . For seven winters before this he had taught in the country schools and had helped on his father's farm. He was a postgraduate student and assistant in botany at the Kansas State Agricultural College from 1895 to 1899 , when he received the degree of M.S. He was a member of the Alpha Beta Literary Society and of the Alma Kansas Students' Coöperative Association.

He was married August 14, I906, in Westmoreland County, Va., to Miss Nellie Antoinette Ames of Westmoreland County, Va., daughter of N. T. Ames and Mary F. (Peck) Ames. His wife's mother was daughter of Professor Peck of Oberlin College, who was appointed minister to the Republic of Haiti by President Lincoln. They have one son, George L. Clothier, Jr., born November I6, I9I2.

Clothier was employed in the United States Forest Service from July, I900, to August, 1905. He spent the years 1905 
to I9II working in the Forest Service and teaching at the Mississippi Agricultural and Mechanical College. Here he was assistant in the horticultural department and later became professor of botany and forestry. In September, I9II, he was appointed professor of forestry at the State College of Washington, Pullman, Wash., which position he now holds.

He writes: "The chief business event of my life since leaving Yale was the purchase of a thousand-acre farm in Kansas in 1905. With but $\$ 80$ cash in my pocket I obligated myself to pay $\$ 13,000$ in seven years' time at six and a half per cent. interest. I always have had the greatest possible faith in agricultural land as a safe investment, particularly in a country with such agricultural resources as Kansas. Before my mortgage fell due, I was able to pay it off in full, by selling land at an advance in price and by saving from my salary. To-day I own I,053 acres of Kansas land free from debt, worth at the lowest market price $\$ 35,000$. I would not part with the land for $\$ 50,000$. Faith in Kansas and 'nerve' have enabled me to be the owner of one of the finest stock farms in the United States, where I propose to spend my declining years practicing 'farm forestry,' plant breeding and stock raising. I hope to teach a few years longer, then retire to my farm to practice what I have taught."

Clothier is a member of the Presbyterian church. Of his political ideas he writes: "Was a Republican till high tariff and legislation promoting trusts drove me first to the Democratic party, then to the People's party, then again to the Democratic party under Bryan, and now to the Progressive party under Roosevelt." He was elected to the office of superintendent of public instruction in Wabaun, Kans., by the Populists and Democrats in 1892 . He is a member of the American Breeders' Association, the American Forestry Association, the National Geographic Society and of the Gesang and Turn Verein.

$\mathrm{He}$ has written many articles for the Kansas Industrialist, Kansas Farmer, Bulletins of the Kansas Experiment Station, Bulletins and Circulars of the Forest Service, Proceedings of the Society of American Foresters, American Forestry Magazine, Bulletins of the Mississippi Experiment Station, American Breeders' Magazine, etc. 


\title{
Albert W. Cooper
}

Business address, 605-607 Columbia Building, Spokane, Wash. Residence, I4I8 South Maple Street, Spokane, Wash.

\author{
4 Akron Street, Boston, Mass.
}

Albert Williams Cooper was born March 10, 1879, in Denver, Colo., the son of Albert Cooper (deceased), a director and officer in a number of business corporations, and Charlotte Eliza (Williams) Cooper. $\mathrm{He}$ is the grandson on his father's side of Henry Cooper and Sarah (Talpey) Cooper, and on his mother's side of Rev. Milton T. Williams and Charlotte (Henderson) Williams. $\mathrm{He}$ has one brother, Edgar Bailey Cooper, B.S. Massachusetts Institute of Technology '05, and one sister, Gertrude May (Cooper) Dean, B.A. Smith College 'o6.

He was prepared at the Roxbury Latin School and in Igor received the degree of B.A, at Harvard, where he was a member of Theta Delta Chi.

He was married June 25, I908, in Boston, Mass., to Miss Gertrude Ellen Homans of Boston, Mass., daughter of George Homans and Elizabeth A. Homans.

After graduation from the Yale Forest School, Cooper held various positions in the United States Forest Service, being engaged on working plans in Minnesota and Texas, and on commercial plans in California. He was at one time superintendent of woodlands for the Delaware \& Hudson Railroad Company, and later chief of silviculture, District $\mathrm{I}$, in the Service. Since January I, I9Io, he has been secretary of the Western Pine Manufacturers Association of Spokane, Wash.

Cooper is a Unitarian. $\mathrm{He}$ is a member of the Inland Club and University Club of Spokane and the Century Club of Washington, D. C.

He has published: Sugar and yellow pine in California, Bull. U. S. Forest Service; A plan for fire protection at McCloud, Calif., Circ. U. S. Forest Service.

\section{Richard T. Fisher}

Business address, Harvard University, Cambridge, Mass.

Residence, Petersham, Mass.

Richard Thornton Fisher was born November 9; 1876 , in Brooklyn, N. Y., the son of Edward Thornton Fisher, B.A. Harvard ' 56 and M.A. '68, and Ellen Bowditch (Thayer) Fisher. His father, the son of George Fisher, a lawyer and president of the North Western Fire and Marine 
Insurance Company of Oswego, N. Y., and Elizabeth Phelps (Huntington) Fisher, served in the Civil War from 1861 to 1863 and since then has been a teacher. His mother's parents were William Henry Thayer, M.D., and Ellen (Handerson) Thayer. He has two sisters: Faith H. Fisher and Eleanor Fisher, B.A. Smith College 'II.

He was prepared at the Harvard School, Chicago, Ill, and received the degree of B.A. at Harvard in 1898 .

$\mathrm{He}$ is unmarried.

Fisher is assistant professor of forestry at Harvard University. In the summer of 1898 , after graduating from Harvard, he acted as field agent of the United States Biological Survey, and during the year I898-99 he was assistant in English at Harvard College. From 1899 to 1903 he was employed in the United States Forest Service, first as student assistant, then as agent and finally as field assistant. Upon graduation from the Yale Forest School he became instructor in forestry at Harvard, which position he held until 1906, when he was made assistant professor. Since 1907 he has also been a member of the firm of Fisher, Cory \& Bryant, now Fisher, Olmsted \& Bryant, consulting foresters, of Boston, Mass.

$\mathrm{He}$ is a Unitarian. $\mathrm{He}$ is a member of the Society of American Foresters and of the Farmers' Grange.

He has published: The redwoods, Bull. U. S. Forest Service; (With H. S. Graves) The woodlot, Bull. U. S. Forest Service.

\section{*Wesley J. Gardner}

\section{Died 1906}

Wesley Johnson Gardner was born January 30,1877 , in Plainfield, N. J., the son of Insley Boice Gardner (died May 30, 1897) and Anna Elizabeth (Bellis) Gardner. He was the grandson on his father's side of Alvah Gardner, who was of English ancestry, and Sarah (Mott) Boice, and on his mother's side of John L. Bellis and Sarah Maria (Dilts) Bellis. He had four sisters: Mabel Washington Gardner and Nellie Dunn Gardner (both deceased), and Mary Craig Gardner and Evelyn Dunn Gardner, B.A. Bryn Mawr 'o8.

He was prepared at the Helena High School, Helena, Mont., and with private tutors, and in 1900 received the degree of B.A. cum laude at Harvard and was awarded honorable mention in philosophy.

He was unmarried. 
After graduation from the Forest School, Gardner entered the United States Forest Service as forest assistant, which position he held from I903 to 1906. His work was directed chiefly along the line of reforestation in the national forest reserves in California, Idaho, Montana, Colorado and Oklahoma.

He was a member of the First Congregational Church of Helena, Mont., and of the Society of American Foresters.

He died of an abscess at the Episcopal Eye, Ear and Throat Hospital in Washington, D. C., June I5, 1906, and was buried in that city.

He had published: Results of a Rocky Mountain forest fire studied fifty years after its occurrence (Address before the Society of American Foresters, April 28, I904), Proc. Soc. Am. Foresters, I, 102, Nov., I905.

\section{Austin F. Hawes}

Experiment Station, Burlington, $V t$.

Residence, 43 South Prospect Street, Burlington, Vt.

Austin Foster Hawes was born March 17, 1879, in Danvers, Mass., the son of Frank M. Hawes, son of Mather Hawes and Laura (Bond) Hawes, and Harriet (Foster) Hawes, daughter of Austin F. Foster and Sarah H. (Gilman) Foster. He has one brother, Richard Withington Hawes, Yale '08, and one sister, Sally G. Hawes.

He was prepared at the Somerville Latin School and received the degree of B.A. at Tufts College in I90r.

He was married June 27, 1908, in Windsor, Conn., to Miss Alice Clapp of Windsor, Conn., daughter of Roswell Clapp and Ida (Pierce) Clapp.

Hawes was employed in the United States Forest Service during the summers of I900, I90I and 1902. In 1903-04 he held the position of forest assistant, and was state forester of Connecticut from I904 to I909. On April I, I909, he was appointed state forester of Vermont and professor of forestry at the University of Vermont.

In politics Hawes is a Progressive. $\mathrm{He}$ is a member of the Society of American Foresters, of the Association of Eastern Foresters and of the Ethan Allen Club, Burlington, Vt.

He has published: (With R. C. Hawley) Forestry in New England, N. Y., Wiley \& Sons, I9I2, 8vo, XV + 479 pp., I4 figs., 2 maps. 


\section{Wallace I. Hutchinson}

Business address, 519 Majestic Building, Denver, Colo.

Residence, 1715 East Colfax Avenue, Denver, Colo.

United States Forest Service, Washington, D. C.

Wallace Irving Hutchinson was born January 30, 1881, in Wolfville, Nova Scotia, Canada, the son of John Robert Hutchinson and Charlotte Hutchinson. On his father's side he is of English, and on his mother's of Scotch descent.

He was prepared at Horton Collegiate Academy, Wolfville, and in Igor received the degree of B.A. from Acadia University, Wolfville, Nova Scotia.

He was married April 12, I9II, in Denver, Colo., to Miss Leila Collom of Denver, Colo., daughter of Martin H. Collom and Augusta L. Collom.

Hutchinson entered the United States Forest Service July r, I90I. Upon graduation from the Yale Forest School in 1903 he was appointed forest agent, which position he held until 1905, serving in California, Nebraska, North Carolina, New Jersey and Pennsylvania. During that year he was forest assistant in the Service, and from then until 1909 he held the position of forester in the Philippine Bureau of Forestry in charge of the southern administrative district, which embraces the island of Mindanao and Jolo Archipelago. During 1909 he studied forest management, extension, etc., in the Federated Malay States, Burma, India, Ceylon, France, Austria-Hungary and Germany. In September, 1909, he received his present appointment of forest assistant in the Pike National Forest, Colorado.

$\mathrm{He}$ is a member of the Baptist church. He is a Republican and a member of the Concatenated Order of Hoo-Hoo.

He has published: A Philippine substitute for lignum vitae, Bull. 9, Bur. For., Manila, P. I., 1908.

\section{Elers Koch}

Business address, United States Forest Service, Missoula, Mont. Residence, 420 Beckwith Avenue, Missoula, Mont.

Elers Koch was born December 12, 1880, in Bozeman, Mont., the son of Hans Peter Gyllemburg Koch and Laurentze Koch, daughter of 
Christian Koch. His grandfather was Hans Peter Gyllemburg Koch of Denmark, a descendant of a long line of ministers of Kirkeburg, Denmark. $\mathrm{He}$ has one brother, Stanley Koch, a graduate of West Point and lieutenant in the United States Army, and two sisters: Martha and Lucie Koch.

He was prepared at the Bozeman High School. During the summer of 1899 he served as student assistant in the United States Forest Service in the state of Washington and in I90I received the degree of B.S. from the Montana State College of Agriculture and Mechanic Arts.

He was married December 27, 1906, in Bozeman, Mont., to Miss Gerda Heiberg-Jürgensen of Copenhagen, Denmark, daughter of Rasmus Emil Heiberg-Jürgensen and Ingeborg Marie (Biering) Heiberg-Jürgensen.

Koch has been employed in the United States Forest Service since graduation from the Yale Forest School. In 1903-04 he was forest assistant, doing boundary work in California, Montana and Wyoming. He was forest inspector in Montana and Wyoming in 1905-06, and since January 1 , 1907, has been supervisor of Lolo National Forest, Missoula, Mont.

$\mathrm{He}$ is a member of the Society of American Foresters.

\section{Francis G. Miller \\ Business address, Wenatchee, Wash. \\ Home address, Seattle, Wash.}

Francis Garner Miller was born June 2, 1866, in Lanark, Ill, the son of Isaiah Miller and Isabella Jane (Moffett) Miller.

He received the degree of Bachelor of Didactics from the Iowa State Teachers College in 1893 , and from that time until 1899 was superintendent of city schools in Iowa. In 1900 he received the degree of $\mathrm{Ph} . \mathrm{B}$. from the University of Iowa, and in I90I the degree of B.S.A. from the Iowa State College of Agriculture and Mechanic Arts. He entered the United States Forest Service in July, 190I. He is a member of Sigma Xi.

He was married September 16, I906, in Kansas City, Mo., to Miss Evelyn DePew Miller of Kansas City, Mo., daughter of G. W. Miller and Catherine DePew (Scruggs) Miller.

Miller is manager of the Wenatchee Columbia Fruit Company of Wenatchee, Wash. He was professor of forestry at the University of Nebraska from 1903 to 1907 and dean of the School of Forestry, University of Washington, from 1907 to 1912. He has held his present position since June, I9I2. 
In politics he is a Progressive. He is a member of the American Forestry Association, the Society of American Foresters, the American Association for the Advancement of Science and the National Geographic Society.

He has published: Studies in the germination of leguminosae, lowa State College; Forest planting in eastern Nebraska, Bull. U. S. Forest Service; Forest planting in the North Platte and South Platte valleys, Bull. U. S. Forest Service; (With Frank B. Kellogg) Forest taxation in Washington, Bull. U. S. Forest Service.

\section{Ellie J. S. Moore}

Route 2, Bozeman, Mont.

Ellie James Sebastian Moore was born in Bozeman, Mont.

In IgoI he received the degree of B.S. from Montana State College.

Moore was in the employ of the United States Forest Service in 1903-04 and has since been principally engaged in ranching.

\section{J. Girvin Peters}

Business address, Forest Service, Washington, D. C.

Home address, 7 East Mt. Royal Avenue, Baltimore, Md.

James Girvin Peters was born November 14, 1876, in Baltimore, Md., the son of Winfield Peters, a lieutenant in the Confederate Army from I86r to I865, and Mary Elizabeth (Girvin) Peters. He is the grandson on his father's side of George Peters, a colonel in the Confederate Army from 186r to 1865, and Sarah (Cordray) Peters, and on his mother's side of James Girvin and Sarah Ann (Smith) Girvin. His ancestry combines German and Scotch-Irish.

He was prepared at Marston's University School, Baitimore, and graduated from Johns Hopkins University in 1900, receiving the degree of B.A. He was a member of Delta Phi and leader of the Glee, Banjo and Mandolin clubs. He spent the year before entering Yale in Oregon in the lumber business with Joseph T. Peters \& Company at The Dalles, and with the Bridal Veil Lumbering Company at Bridal Veil. On a trip up Mt. Hood he met Gifford Pinchot, who told him of the Forest School at Yale.

He was married November 12, 1907, in Garrison, Md., to Miss Harriet Dugan White, of Garrison, Md., daughter of Horace W. White and Jane M. (Ward) White. They have two sons: Horace White Peters, born 
September 3, 1908, in Ilchester, Md., and James Girvin Peters, Jr., born May 18,1911 , in Baltimore, Md.

Peters has been employed in the United States Forest Service since graduating from the Yale Forest School. In 1903 he was made forest assistant, in 1908 forest examiner, in I909 chief of state and private coöperation, and in IgIr chief of state coöperation. Since 1905 he has been a member of the Graduate Advisory Board of the Yale Forest School, his present term expiring in 1916. He was a member of the Committee on Admissions from 1909 to I9II, and in 1908 and 1912 of the Committee on Meetings, of the Society of American Foresters.

He writes: "From July to September, 1903, studied forest conditions in Northern New Hampshire. From December to March, 1904, studied waste in lumbering yellow pine in Louisiana and Texas. In October and November, I904, gave a six weeks' course at Biltmore Forest School, North Carolina, on field methods of the Forest Service. This course was repeated in October and November of 1905. From May to September, 1905, made forest working plans in Hudson River valley, New York. In June and July, I906, accompanied Gilbert Rogers of the British India Forest Service on a tour of lumbering regions and national forests, covering the Southern Appalachians, the long leaf pine country, the western yellow pine regions of the Black Hills, S. Dak., and the Southwest, and the redwood and sugar pine districts in California. In August and November made a working plan for the Henry's Lake district of the Targhee Forest, Idaho. From May to September, I907, engaged in a coöperative timber sale with the War Department on Fort Wingate Military Reservation, N. Mex. From 1908 to I9I2 assisted in directing the policy of coöperation between the Forest Service and states, including Porto Rico, with a view to the enactment by them of remedial forest legislation. In December, I9II, attended the Yale Forest School reunion, which was a corker."

Peters is a member of the Protestant Episcopal church. In politics he is a Democrat. He says: "I am for regulated competition as against legalized monopoly, publicity as against star chamber deals, conservation in all things, woman's suffrage (despite her being the 'more deadly' of the species), and any progressive measure which is constructive." $\mathrm{He}$ is a member 
of the Society of American Foresters, of the Baltimore Club and the Bachelors Cotillon Club, Baltimore, and the Green Spring Valley Hunt Club, Garrison, Md.

He has published: Notes on a northwestern fir, the noble fir, abies nobilis, Forestry and Irrigation, Sept., 1902, 362; Notes in logging southern yellow pine, Yearbook U. S. Dept. Agric., 1905, 483; Work of the Forest Service in the South (Address before the Southern Conservation Congress in Atlanta), Am. Lumberman, Oct. 15, 1910, 54; Forest fire protection in the United States (Address before the Canadian Forestry Association in Quebec, Jan., I9II), Canadian Forestry Ass'n Ann. Rep., I9I I, 51; Uniform forest legislation (Address before the Southern Commercial Congress, Forest Section, in Atlanta, March, I9II), Am. Lumberman, March 18, 1911, 40; Coöperation with states in fire patrol, $A m$. For., July, I911, 383; Coöperative fire protection under the Weeks Law and General principles of forestry (Two addresses before the North Carolina Forestry Association in Raleigh, Feb. 21, 1912), Economic Paper 25, 27 and 44; N. C. Geol. and Econ. Sur., Forest fire protection under the Weeks Law in coöperation with states, Circ. 205, U. S. Dept. Agric., For. Ser., March, 1912; Rural mail patrol, Am. For., Aug., 1912, 533 ; also two songs: Rah, for Black and Blue, "Songs of all Colleges," N. Y., Hinds \& Noble, Igoo; and We're here to win again, "Johns Hopkins Songs," Baltimore, Willis \& Company, I909; and Black and Blue, a banjo solo, Baltimore, Eisenbrandt \& Sons, I897.

\section{Samuel N. Spring}

Business address, New York State College of Agriculture,

Cornell University, Ithaca, N. Y.

Samuel Newton Spring was born February 5, 1875, in Sioux City, Iowa, the son of Winthrop Norton Spring, a business man, and Ellen Elmira (Newton) Spring. He is of New England ancestry and a descendant of Samuel Hopkins, D.D., who graduated at Yale in 1749, Samuel Spring, D.D., Yale I8I r, and Gardiner Spring, D.D., LL.D., Yale 1805, the latter being valedictorian of his class.

He was prepared at the local schools in Le Mars, Iowa, and at Hull Academy, Hull, Iowa. In 1898 he graduated from Yale, where he received Junior oration and Senior dissertation appointments, was a member of the Freshman Glee Club, the Apollo Glee Club and the Banjo and Mandolin clubs.

He was married November 29, 1900, in New Haven, Conn., to Miss Adah Elmindorf Bowman of New Haven, daughter of Peter E. Bowman and Mary C. Bowman. They have two sons: Ernest Walker Spring, born June I, 1903, in New Haven, Conn., and John Bowman Spring, born September 7, 1907, in Washington, D. C. 
Before entering the Yale Forest School, Spring was with J. V. Farwell \& Company, wholesale drygoods dealers in Chicago, Ill. (1898-190I). During the summer of 1902 he was student assistant and in the summer of 1903 field assistant in the Bureau of Forestry, United States Department of Agriculture. From 1903 to 1905 he was professor of forestry at the University of Maine, Orono, Maine. For the next four years he was engaged in government work in the United States Forest Service. In 1906-07 he was engaged in coöperative work with railroads and individual landowners in the Middle West and Louisiana, beginning as assistant forest inspector, and subsequently being in charge of the work. In 1907 he became chief of the Office of Extension, visiting the Pacific coast and the Rocky Mountain states in connection with his duties of inspection and administration. On February I, 1909, he began the private practice of forestry at Washington, D. C. Later in the same year he was appointed state forester of Connecticut and forester of the Connecticut Agricultural Experiment Station at New Haven, and while in these positions gave a series of lectures in the Yale Forest School. On October I, 1912, he became professor of forestry in the New York State College of Agriculture, Cornell University.

$\mathrm{He}$ is a Congregationalist. In politics he is "Republican so far as general political issues are concerned but does not necessarily vote that ticket." He was a member of the Special Commission on Taxation of Woodland for Connecticut in 19II-I2. $\mathrm{He}$ is a member and director of the American Forestry Association, a member of the Eastern Foresters' Association, the Connecticut Forestry Association and the Society of American Foresters. He is Secretary of the Class of 1903; Yale Forest School.

He has published: Control and prevention of forest fires, Report of the forest commissioner, Maine, 1904; Second growth white pine in Maine. Report of the forest commissioner, Maine, 1906; The natural replacement of white pine on old fields in New England, Bull. 63, U. S. Forest Service, I905; Forest planting on coal lands in western Pennsylvania, Circ. 4I, U. S. Forest Service, 1906; Report of the State Forester, 1910, Biennial Rep., Conn. Agric. Exp. Sta., Pt. XI, I909-Io; Forest fire manual, State Forester's Office, I9I2. 


\section{William D. Sterrett}

Business address, United States Forest Service, Washington, D. C. Residence, Pierce Mill Road, Washington, D. C.

William Dent Sterrett was born March 2, 188r, in Bedford, Pa., the son of Rev. Dr. James Macbride Sterrett, M.A. Harvard '70, S.T.B. Cambridge Theological Seminary '72, a clergyman in the Protestant Episcopal church, and Adlumnia (Dent) Sterrett. His father was formerly professor of philosophy in George Washington University and is the author of several books on philosophy. His father's antecedents were from Center County, Pennsylvania, and were Scotch-Irish, French-Huguenot and German. His mother's ancestors were from Charles County, Maryland, and were English and Scotch-Irish. He has four brothers: Lieutenant Robert Sterrett, B.S. Lafayette, Pa.; Rev. Henry Hatch Dent Sterrett, B.A. Columbian (now George Washington) ' 98 , B.A. Harvard ' 99 and M.A. 'oo, and Cambridge Theological Seminary '03; Douglas B. Sterrett, George Washington ' 02 ; and John A. Sterrett, E.E. Princeton. Two other children are deceased.

He was prepared at Columbian Academy, Washington, and before entering Yale received the degree of B.A. from George Washington University in 1900 and the same in 1901 from Harvard, where he was a member of Theta Delta Chi.

He was married November 19, 1908, in Frankford, Del., to Miss Ida Topping Gum of Frankford, Del., daughter of Dr. F. M. Gum and Mary C. Gum. They have two sons: William Dent Sterrett, Jr., born September 9, I909, in Manila, P. I.; and J. Macbride Sterrett, 3d, born November 26, I9I1, in Washington, D. C.

Sterrett was appointed forest assistant in the Forest Service in June, 1903, which position he held until March, 1908. He then became consulting forester in private work, and in December, I908, received the appointment of forester to the Philippine Islands in the Bureau of Forestry. He held this position until January, 1910. Since April, 19I0, he has been forest assistant in the United States Forest Service with headquarters at Washington, D. C. He writes: "Studied forestry in Germany, Switzerland, Austria and France from April to December, I904. Cruised a 500,000 acre timber tract in Chihuahua, Mexico, April to June, 1908, for the Development Company of America, of New York City. In connection with forest work in the Philippine Islands completed a tour around the world."

Sterrett is a member of the Protestant Episcopal church. In politics he is a Progressive. $\mathrm{He}$ is a member of the University Club of Washington, D. C. 


\section{Henry G. Stevens}

Business address, 615 Stevens Building, Detroit, Mich.

Home address, I075 Woodward Avenue, Detroit, Mich.

Henry Glover Stevens was born January 18, 1879, in Detroit, Mich., the son of William H. Stevens (died in Igor in Detroit), and Ellen (Petherick) Stevens, born in Cornwall, England. He has one brother, William Petherick Stevens, Ph.B. Yale '93.

He was prepared at Thacher School, Nordhoff, Calif., and graduated from the Sheffield Scientific School at Yale in 1902, where he was treasurer of the Sheff Y. M. C. A., a member of the Junior and Senior track teams and of the Senior cross country and debating teams.

He is unmarried.

After graduating from the Forest School, Stevens traveled for two years in Europe and India studying forestry. In January, 1905, he entered the employ of H. W. Noble \& Company, bankers of Detroit, Mich. He became secretary of the BumpusStevens Company (investment securities) in October, 1906. At present he is in the real estate business with the Stevens Land Company, Ltd.

$\mathrm{He}$ is a member of the Episcopal church.

\section{Harry D. Tiemann}

Business address, Forest Products Laboratory, Madison, Wis.

Residence, 135 Prospect Avenue, Madison, Wis.

Harry Donald Tiemann was born March 26, 1875, in Brooklyn, N. Y., the son of Julius Harry Tiemann, who was lieutenant in the 159th Regiment of the Union Army in the Civil War, and Margaret Augusta (Megie) Tiemann, daughter of Rev. D. E. Megie of Boonton, N. J. $\mathrm{He}$ is the grandson of Julius W. Tiemann, brother of Ex-Mayor Tiemann of New York City and son of Anthony Tiemann of New York City.

He was prepared at Froebel Normal Institute, New York City, and Pratt Institute High School. He received the degree of M.E. from Stevens Institute of Technology in 1897 , and before entering Yale taught chemistry at Pratt Institute and mechanical engineering at the University of Pennsylvania. He entered the Forest Service in 1900 and was employed in field work in management.

He was married December 8, I903, in Brooklyn, N. Y., to Miss Elizabeth Minerva Trelease of Newark, N. J., daughter of Charles Carroll Trelease and Elizabeth R. (Loder) Trelease. They have one son, 
Theodore Donald Tiemann, born December 13, 1907, in New Haven, Conn.

Since his graduation from the Yale Forest School Tiemann has been in the employ of the United States Forest Service. From 1903 to the fall of 1909 he had charge of the Yale Timber Testing Laboratory. During the winter of 1909-10 his headquarters in the Service were in Washington, D. C. At the present time he is chief of the section of timber physics at the Forest Products Laboratory, Madison, Wis., and is also lecturing at the University of Wisconsin. He has been engaged in this work since the spring of 1910. In 1911-12 he carried on experiments in drying eucalyptus in California. He has taken out five patents on apparatus and a new method of drying lumber in dry kiln. These are dedicated to public use.

Tiemann is a member of the Congregational church. He is a member of the American Society for Testing Materials, the Society of American Foresters, the American Forestry Association, the Wisconsin Horticultural Association and the Society for Protecting New Hampshire Forests.

He has published: The mechanical relation of force and mass, Sterens Ind., Oct., I90I, 15 pp., illus.; (With Thomson and Ophüls) Test of a Nash gas engine, Stevens Ind., Oct., 1897, illus.; A new hypsometer, Stevens Ind., Jan., 1904, illus., also For. Quart., 1904; The structure of red gum wood, Bull. 58, Forest Service, 1905, illus. with scale drawings from the microscope; The effect of moisture and other extrinsic factors upon the strength of wood, Proc. Am. Soc. for Test. Mat., VII, pp. 582-596, illus., I907; Methods for making discounts for defects in scaling logs, and cull rule, For. Quart., III, pp. 354-357, 1905; The effect of speed of testing upon the strength of wood and the standardization of tests for speed, Proc. Am. Soc. for Test. Mat., VIII, I6 pp., illus. by diagrams, 1908; Some results of dead load bending tests of timber by means of a recording deflectometer, Proc. Am. Soc. Test. Mat., IX, illus., 1909; The microscopic structure of wood in its relation to penetration by preservatives, Bull. I07, Am. Ry. Eng. \& Maint. of Way Ass'n, 1909, 16 pp., illus. by microphotographs; The physical structure of wood in relation to its penetrability by preservative fluids, Bull. I20, Am. Ry. Eng. \& Maint. of Way Ass'n, I910, I6 pp., illus. by 18 photomicros; The theory of impact and its application to the testing of materials, Jrl. Franklin Inst., Oct. \& Nov., 1909, 52 pp. illus. by diag.; The log scale in theory and practice, summarizing results of an experimental research carried on at the mills, Proc. Soc. Am. Foresters, 1910; The microscopic work of the laboratory of forest products on the struc- 
ture of wood, Am. Forestry, April, I9I I, illus. by photomicros; The effect of moisture on the strength and stiffness of wood, Bull. 70, U. S. Forest Service, 1906, I44 pp., illus.; Strength of wood as influenced by moisture, Cir. 108, U. S. Forest Service, 33 pp., illus.

$\mathrm{He}$ has in preparation: Principles of drying lumber and humidity diagram, Bull., U. S. Forest Service; A new dry kiln (invented by the author), Bull., U. S. Forest Service; Is California eucalyptus stuitable for lumber? results of research and kiln drying experiments, Bull., U. S. Forest Service.

\section{Theodore S. Woolsey, Jr.}

Business address, Brown Shipley Company, London, England

Home address, Albuquerque, N. Mex.

250 Church Street, New Haven, Conn.

Theodore Salisbury Woolsey, Jr., was born October 2, 1880, in New Haven, Conn., the son of Theodore Salisbury Woolsey, LL.D., Yale '72, professor of international law in the Yale Law School, and Anne Gardner (Salisbury) Woolsey, and is the grandson of Theodore Dwight Woolsey, LL.D., D.D., Yale I820, president of Yale College from 1846 to I871, and a descendant of Jonathan Edwards, Yale I720. A brother, Heathcote Muirson Woolsey, graduated from Yale in 1907.

He was prepared at St. Mark's School at Southboro, Mass., the Pomfret School of Pomfret, Conn., and the Fay School, and graduated from Yale in 190r. While there he was on the editorial board of the Yale Daily Neres and was a member of Alpha Delta Phi.

He was married March 15, I908, in Albuquerque, N. Mex., to Miss Ruby Hilsman Pickett of Dawson, Ga., daughter of Thomas Hamilton Pickett, a lawyer and soldier. Mrs. Pickett's maiden name was Davenport. They have four daughters: Elizabeth Davenport Woolsey, born December 25, 1908, in Albuquerque, N. Mex.; Ann Salisbury Woolsey, born June 5, I9ro, in Albuquerque; Edith Woolsey, born April 25, I9I2, in Lausanne, Switzerland; and Sarah Woolsey, born April 26, 1913, in Paris, France.

Woolsey is an assistant district forester in District 3 with headquarters at Albuquerque, N. Mex. He was appointed to this position in October, I908. Previous to this he had held successively the positions of assistant forest expert, forest assistant and forest inspector, being appointed to the last on May 15, 1907. During March and April of I9I I he was acting chief of silviculture. He spent the year I904-05 studying government forestry in Germany, France and India and is at present on leave of absence, studying in Austria and France. He is a member of the Graduate Advisory Board of the Yale Forest School. 
He writes: "The windy, sun baked hills in the neighborhood of Marseille (where not denuded) are covered with pin d'alep which during the summer and winter months must exist almost entirely without rain. Even at Grésque at an elevation of 350 meters the rainfall is but $69 \mathrm{I}$ millimeters during an average year. Add to the summer droughts a temperature of $25^{\circ}$ to $37^{\circ}$ centigrade and the vegetative conditions become intolerable. The fellings consequently are light and rarely remove more than 25 per cent. of the volume. The selection system is employed because in the words of the inspector: 'We are afraid of the regular shelterwood fellings because after the parent trees are removed the young crop is exposed to the full force of the wind and drought. To avoid heavy losses during the periodic droughts we employ light selection fellings: if once the ground becomes denuded artificial restocking is a difficult undertaking.'

"And no wonder it is difficult! In the Commune of Marseille (Serie de reboisement de la Gordiale), the government has purchased some 800 hectares of denuded calcareous hills as a demonstration forest and to temper, if possible, the climate, of Marseille by surrounding it with forests. Here a local nursery has been established and systematic reforestation is in progress. It has taken years of study to determine the best methods.

"They sow the pin d'alep in seed spots where the conditions are not too unfavorable and use ball plants (pot method) where seeding results or would result in failures. The sowing and planting is in the fall just before or during the rains. Spring sowing is equally successful until the summer drought starts but during this period the losses are enormous. The seed spots are carefully cultivated and cleared of stones and rocks. The size varies somewhat but on poor ground the spots are .80 by .60 meters and 30 to 35 centimeters deep. They cost from 6 to 12 cents each, and are irregularly spaced 3 to 4 meters apart by a rough quincieux system. When the soil is ready for the seed the surface is 2 to 5 inches below the ground level. This depression collects the water a little during the rains and protects the seedlings against the wind. Perhaps 60 seeds (a small handful) are sown in each spot and are raked into the soil to a depth of $I$ to $I / 2$ centimeters. As soon as the sowing is 
complete a uniform cover of brush is placed on the seed spot and is held down by a good-sized rock. The success of this method is phenomenal. Its chief features are: large wellworked seed spot; heavy sowing to discount certain loss of at least 50 to 90 per cent. of the seedlings which germinate; the brush cover; sowing before or during the rains.

"The same seed spots are prepared for planting and the pin d'alep, after one year in the seed bed and one year in the terra cotta pot, is ball planted after the pot is removed. When the ground is moist the ball of earth around the roots (often caked hard) is loosened to give the roots a better chance. This method is so expensive it is only used where absolutely necessary."

$\mathrm{He}$ is an Episcopalian. $\mathrm{He}$ is a Mason, a member of the Graduates Club of New Haven, the University Club of New York City and the Societé de Franche Compte et Belfort of Besançon, France.

He has published: Management and natural reproduction of chir pine near Dehra Dun, India, For. and Irr., April, 1906; Bulletin Ior. He has written articles for Forest Quarterly, Indian Forester and has delivered lectures before Society of American Foresters. He has in preparation a book, "Forest management in France."

\section{Non Graduates}

\section{Carl G. Crawford}

Business address, $40 I$ West Main Street, Lonisville, $K y$.

Residence, Corner Fourth and Breckinridge Streets, Louisville, Ky.

Carl G. Crawford was born April 10, 1870, in Newark, Licking County, Ohio, the son of James McCann Crawford and Sarah Elizabeth (Beckham) Crawford. On his father's side he is of Scotch-Irish, and on his mother's of English ancestry. He has three sisters: Eva (Crawford) McCann, Stella Crawford and Bertha (Crawford) Spencer.

He received the degree of B.S. from Ohio Wesleyan University in 1898 , and before entering Yale was a teacher in public schools and at Ashland College.

He was married November 27, 1901, in New Haven, Conn., to Miss Mary Gay of Parkersburg, W. Va., daughter of Mr. and Mrs. Albert Gay. They have no children. 
Crawford is general manager of the American Creosoting Company of Louisville, Ky. After leaving Yale he became forest assistant in the United States Forest Service, and afterward held the positions of chief of the section of wood preservation and chief of the office of wood preservation. He was later appointed general superintendent of the American Creosoting Company and since January I, I909, has held his present position.

$\mathrm{He}$ is a Presbyterian. $\mathrm{He}$ is a member of the Society of American Foresters.

\section{Samuel B. Detwiler}

Business address, 1112 Morris Building, Philadelphia, Pa.

Bala, Pa.

Samuel Bertolet Detwiler was born September 18, r881, in Oaks, Pa., the son of Samuel Bertolet Detwiler, a physician, and Frances $\mathbf{H}$. (Longacre) Detwiler. On his father's side he is of German and French, and on his mother's of German ancestry. He has three sisters: Laura L. (Detwiler) Yocum, Elizabeth D. (Detwiler) Hoar and Bertha L. (Detwiler) Storey; and two brothers: John L. Detwiler and Dr. William P. Detwiler.

He attended no college before entering Yale. He grew up on a farm, attending the country school and Phoenixville $(\mathrm{Pa}$.) High School, and had two years of office and shop experience after leaving school.

He was married December 24, 1907, in Washington, D. C., to Miss Kate Emily Price of Washington, D. C., daughter of Robęrt A. Price. They have two sons: Robert A. Detwiler, born September 20, I909, and Samuel B. Detwiler, born September 21, I909.

In 1906 Detwiler received the degree of B.S. in forestry from the University of Minnesota. He was in the employ of the United States Forest Service from 1902 to 1907 . In 1907-08 he held the position of assistant professor of forestry at the University of Minnesota. From I908 to I9II he was forester and woods superintendent of the Forest Products Company, Red Wing, Minn., and in August, I9II, received his present appointment of executive officer and general superintendent of the Pennsylvania Chestnut Tree Blight Commission.

$\mathrm{He}$ is a member of the Baptist church and in politics is an independent Progressive. He was elected to membership in Sigma $\mathrm{Xi}$ at the University of Minnesota. 


\title{
George Griswold
}

Lyme, Conn.

George Griswold attended the Sheffield Scientific School during 1894-95 and the Yale Forest School in I9OI-02. No information has been received from him for this record.

\section{Frank C. Hinckley}

Business address, 26 Central Street, Bangor, Maine Residence, I12 Broadway, Bangor, Maine

Hinckley is a forester and surveyor in Bangor, Maine.

\author{
Felix R. Holt \\ Business address, Navy Yard, Norfolk, Va. \\ Home address, Florence Court, Washington, D. C.
}

Felix Renouf Holt was born June 24, 1879, in Washington, D. C.

He was prepared at the Friends' School, Washington, D. C., and in rgor received the degree of B.A. from West Maryland College.

Holt is a paymaster in the United States Navy and has been stationed at the Navy Yard in Norfolk, Va., since September 26, I912, having returned from his last cruise on July I2 of the same year. At various times he has been stationed in the Philippines, Manchuria and China. He was appointed to his present rank on July 30 , 1905 . 


\title{
CLASS OF 1904 \\ Graduates holding Degree of M.F.
}

\section{John Appleton}

\author{
Bangor, Maine
}

John Appleton was born in 1879 in Bangor, Maine.

He was prepared at Hotchkiss School, Lakeville, Conn., and in 1902 received the degree of B.A. at Bowdoin College.

Upon graduation from the Yale Forest School Appleton entered the Bureau of Forestry and was assigned to the division of forest products (experimental work). In 1906 he was a consulting forester in private work in Bangor, Maine. He has furnished no information for this record.

\section{Robert W. Ayres}

Business address, Sonora, Calif.

Forest Service, San Francisco, Calif.

Robert Williams Ayres was born October 6, I880, in Cincinnati, Ohio, the son of Stephen Cooper Ayres, Miami '6r, oculist and aurist, dean of the Cincinnati Medical School, member of the medical staff of the Ohio Medical College (Cincinnati University), and surgeon and brevet captain in the Civil War, and Louise (McLean) Ayres, daughter of S. B. W. McLean, owner of Cincinnati Enquirer in 1860. He is of Scotch-Irish ancestry on his father's side. He has had two brothers, Wylie McLean Ayres, M.D., Yale '97, and Rowan Ayres, Yale '98 S. (died August 13, 1912); and two sisters, Louise and Gertrude Ayres.

He was prepared at Franklin School, Cincinnati, Ohio, and graduated from the Sheffield Scientific School at Yale in 1903. Here he was a member of Delta Psi (St. Anthony) and chairman of the Statisticians Committee.

He was married August 8, 1906, in Los Angeles, Calif., to Miss Kate Dowson O'Neill of New York City, daughter of Henry O'Neill and Annie Dowson (Coyle) O'Neill. They have three daughters: Nancy McLean Ayres, born May 6, 1907, in Pasadena, Calif.; Katherine Louise Ayres, born December 4, 1909, in Sonora, Calif., and Frances Rowan Ayres, born March 9, 1912, in Sonora. 
Ayres is forest supervisor in the California district. He writes: "I was appointed forest assistant in the Forest Service July I, I904. From July 4, I904, until July 10, 1905, I was stationed in St. Louis, Mo., working in the Division of Forest Products of the Forest Service. In July, 1905, I was sent to California on experimental work in the same division. I was transferred to forest reserve work in January, 1906 (still in the Forest Service), where I remained until November of 1907. During that time I was engaged in the examination of land for national forest purposes and reported on about four million acres, which were subsequently included in the National Forests. In November, 1907, I was transferred as forest assistant to the Stanislaus National Forest, with headquarters at Sonora, Calif. I was placed in charge of the forest in June, I908, and in January, 1909, was appointed supervisor."

In politics he is a Progressive. He is a Presbyterian and a member of the Military Order of the Loyal Legion (by inheritance), the Society of American Foresters, and the Concatenated Order of Hoo-Hoo.

\section{Hugh P. Baker}

New York State College of Forestry, Syracuse, N. Y.

Hugh Potter Baker was born January 20, I878, in St. Croix Falls, Wis., the son of Joseph Stannard Baker and Alice (Potter) Baker. His father was major of the Ist Cavalry, District of Columbia, during the Civil War and since 1870 has been in the lumber and land business in northern Wisconsin. He is of English ancestry on his father's side, the first of the family coming to Boston in 1638. His mother's family came to New Haven in 1630 and lived for several generations in East Haven. His mother is a great, great, great granddaughter of Dr. Ezra Stiles, an early president of Yale. He has five brothers: Ray Stannard Baker, B.S. Michigan Agricultural College; Charles Fuller Baker, B.S. Michigan Agricultural and M.S. Leland Stanford, Jr., University; Harry Denio Baker; Clarence Dwight Baker, B.A. Macalester College; and James Fred Baker, B.S. Michigan Agricultural College ' $\mathrm{O} 2$ and M.F. Yale Forest School '05, and one sister, Winnie Baker, B.A. Carleton College.

He was prepared in the Preparatory Department of Macalester College, St. Paul, Minn. He taught in a district school for two years (1895-97), and worked in a real estate office and lumber yard three summers. In I901 he received the degree of B.S. from the Michigan Agricultural Col- 
lege and in December, 1910, the degree of Doctor of Economics from the University of Munich.

He was married December 27, 1904, in Saginaw, Mich., to Miss Fleta Paddock of Three Oaks, Mich., daughter of Steven Tappan Paddock and Aurelia (Butler) Paddock. They have one daughter, Carolyn Baker, born January I, 1906, in Ames, Iowa, and one son, Clarence Potter Baker, born September 16, 1910, in Munich, Germany. Another son, Steven Paddock Baker, was born August 26, 1908, in State College, Pa., and died January 19, 1911, in Columbus, Ohio.

Baker has been dean and professor of silviculture at the New York State College of Forestry, Syracuse, N. Y., since April I, I9I2. From I90I to I904 he was employed as assistant forest expert and agent in the United States Bureau of Forestry and Forest Service. He was forest assistant from 1904 to I9II. During the years $1904-07$ he was assistant and associate professor in charge of forestry at Iowa State College, and from 1907 to I9I2, professor of forestry at Pennsylvania State College.

He writes: "Upon graduation from Michigan Agricultural College in I90I, entered the Division of Forestry and spent summer in Western Nebraska and Eastern Wyoming under R. S. Kellogg, working on report which resulted in Sand Hill Reserves. In November, I90I, was sent to Lancaster County, Va., to make a study of plantations put out by the Landreth Seed Company. In the spring of 1902, took charge of party studying sand dunes along Columbia River in coöperation between the United States Forest Service and the Oregon Short line. Study resulted in report and two small sand dune stations afterwards abandoned. Summer of 1903 spent examining public lands in Central Idaho, under direction of E. T. Allen. Resulted in Sawtooth National Forest. Summer of 1904 spent in making planting plans in Michigan, Wisconsin and Iowa and in preliminary studies of nature and planted timber of Iowa. Summer of 1905 had charge of two parties studying forest conditions of Iowa, report on which resulted in Circular I54 of Forest Service. Summer of 1906 laid out nursery sites at ranger headquarters in New Mexico. Have had ten years of consecutive work with Government Forest Service."

Baker is a Presbyterian. He is a member of the Society of American Foresters, the American Forestry Association, the American Geographical Society of New York, the Royal Geo- 
graphical Society of London, the American Breeders' Association, the American Civic Association, the Deutsche Dendrologische Gesellschaft, the Masonic Lodge and the Society of Colonial Wars.

He has published: Nature and planted timber of Iowa, Circ. I54, U. S. Forest Service; Holding and reclamation of sand dunes and sand wastes by tree planting, Rep. Iowa Acad. Sci.; Die Prärien in Zentralnordamerika und ihr Wert für Forstkultur, Dissertation, Univ. Munich.

\section{William H. von Bayer}

Business address, Indian Office, Washington, D. C.

Residence, The Earlington Apartments, Sixteenth Street and Colorado Road, Washington, D. C.

William Hector von Bayer was born September 18, I876, in Washington, D. C., the son of Hector Raimund von Bayer and Caroline Mathilde (von Cornberg) von Bayer. His father at different times held the positions of engineer of the Lighthouse Service and of the Life Saving Service, United States Treasury Department and civil engineer under the United States Navy Department in I870. His father is also a former president of the German-American Technical Society and a member of the Cosmos Club and the Engineers' Club of Washington, D. C. $\mathrm{He}$ is the grandson on his father's side of August von Bayer and Marie (Lamery) von Bayer. The former was director of the Royal Museum of Karlsruhe, Baden, and court painter of Emperor William I; the latter was the sister of the former Prime Minister of Baden, August Lamery. On his mother's side he is the grandson of Freiherr Otto von Cornberg, officer on the General Staff of the German Army, and Wilhelmina Thvene. He has two brothers: August $\mathrm{H}$. von Bayer, C.E. Cornell 'oo, and Rudolf von Bayer.

He was prepared at the public and high schools in Washington, D. C., and in 1904 received the degree of B.A. from Cornell University. $\mathrm{He}$ attended the University of Strassburg in the year I899-00.

He was married June 13, I912, in Mount St. Albans, to Miss Margareta Alma Lorleberg of Hanover, Germany, daughter of Richard Lorleberg, court violoncellist at the Royal Conservatory of Music at Hanover, Germany.

Von Bayer is forest examiner at large in the United States Indian Service with headquarters at Washington, D. C. From I904 to 1907 he held the position of forest assistant in the United States Forest Service, and from 1908 to I9Io was chief of Section E of reconnaissance. He was forest assistant in 
the United States Indian Service from July, I9Io, until May, 1912, when he received his present appointment.

In politics he is a Progressive. In $1895-96$ he was captain of Company A and major of the r86th Battalion of the W. H. S. C., and in 1898 captain of Company A, C. U. C. C. $\mathrm{He}$ is a member of the Society of American Foresters, the German-American Technical Society, the University Club of Washington, D. C., and of A. A. S. R. $32^{\circ}$, S. J. Freemasonry.

He has published: Statistics giving area of timber lands, quantity and stumpage value of timber on Indian reservations and cost of care and protection of timber for fiscal year ended June 30, I9II; Table showing sawmills on Indian reservations, quantity and value of timber cut, cost of forest protection and average area covered by each employee for fiscal year ended June 30, I9II (appears as a part of the Annual Report of Commission of Indian Affairs, pp. 193-199); various forms for the simplification of Indian forestry work.

\section{Fred W. Besley}

Business address, Johns Hopkins University, Baltimore, Md. Residence, II3 Beechdale Road, Roland Park, Baltimore, Md.

Fred Wilson Besley was born February 16, 1872, in Vienna, Va., the son of Bartholomew Besley, a farmer, and Sarah (Wilson) Besley. On his father's side he is of Huguenot and Quaker, and on his mother's of English ancestry. He has four sisters: Grace A. Besley, Elsie M. Besley, Florence E. Besley, a graduate of the Nurses' Training School of Columbia Hospital, Washington, D. C., and Naomi I. Besley, a graduate of the Nurses' Training School of the University of Virginia, and one brother, LaMoree G. Besley.

In 1892 he received the degree of B.A. from the Maryland Agricultural College, where he studied military tactics and served in the college battalion. After graduating from college he taught in the public schools of Virginia and later served as deputy treasurer of Fairfax County, Va. In 190I-03 he was employed as forest student in the Forest Service and entered the Yale Forest School in January, 1903.

He was married September 19, 1900, in Washington, D. C., to Miss Bertha Adeline Simonds of Washington, D. C., daughter of Elmer A. Simonds (deceased), and Susan Adelle Simonds. They have two daughters: Florence Eugenia Besley, born August 29, 190I, and Helen Besley, born July 3I, I907; and two sons: A. Kirkland Besley, born November 9, 1902, and Lowell Besley, born August 20, 1909.

Besley is employed by the Maryland State Board of Forestry as state forester of Maryland. He has held this position since 
June 25, 1906. He was at one time superintendent of the forest nursery and planting operations in the United States Forest Service at Halsey, Neb., and on Pike's Peak Forest Reserve. At this time he lectured on forest planting at Farmers' Institutes in Colorado. He has been a delegate to a number of forestry conventions and state forest representative on several forestry committees.

$\mathrm{He}$ is a member of the Roland Park Presbyterian Church of Baltimore, Md. In politics he is an independent Democrat. $\mathrm{He}$ is a member of the Society of American Foresters, the American Forestry Association, the National Geographic Society and of the Patrons of Husbandry.

He has published: Growing forest trees on the dry lands, Dry Land Agric., about Sept., Ig06; Forestry in Maryland, Rep. St. Hort. Soc., I906; Some of the problems of forestry, Rep. St. Hort. Soc., I907; The practice of forestry, Rep. St. Hort. Soc., I908; The forests and their products (Md.), Md. Weather Service, III, Baltimore, Md.; Forest mapping and timber estimating, Proc. Soc. Am. Foresters, 1909; Woodlot forestry, For. Leaves, Philadelphia, Pa., July, I908; Mutual forest interests of Maryland and Pennsylvania, For. Leaves, Philadelphia, Pa., about June, I9II; State forest problems in Maryland, Am. For., Washington, D. C., July, I912; Report of the State Board of Forestry for 1906-07, 1908-09, I9I0-II; chapter on The timber cut in Report on the wood-using industries of Maryland; The forests of Allegany County, Maryland, report; The forests of Kent County, Maryland, report; Increasing the durability of fence posts (bulletin).

\section{John H. Bridges}

Business address, Drawer I607, Tacoma, Wash.

Home address, Grandview, Wash.

John Henry Bridges was born October 13, 1878, in Rose Hill, Ala., the son of Tilman Barnard Bridges and Mary Elizabeth (Stewart) Bridges. His ancestors on his father's side were English colonists in South Carolina and on his mother's side French and English colonists in Virginia. He has two brothers: Benjamin T. Bridges, B.S. University of Florida, and Barnard T. Bridges, M.D. State Medical College of Alabama.

He was prepared at the common schools of Alabama, at Bartow High School of Florida, and at Southern Florida Military Institute, and in 1902 received the degree of B.S. from the Florida Agricultural College.

$\mathrm{He}$ is unmarried. 
Bridges is forester to the Weyerhaeuser Timber Company of Tacoma, Wash. He has held this position since 1908. He was at one time assistant forester in the Philippines and later forest assistant in the United States Forest Service.

$\mathrm{He}$ is a Democrat.

\section{Horatio J. Brown}

Business address, 414 Lewis Building, Portland, Ore.

Horatio Jones Brown was born September 27, 1879, in Schenectady, N. Y., the son of Clinton C. Brown and Anna (Ramsey) Brown. His father served four years in the Civil War, is lieutenant-colonel of the 134th New York Volunteers and a member of the Military Order of the Loyal Legion. On his father's side he is of English, and on his mother's of Dutch ancestry. He has three brothers: Albert, Wayne and Theodore Brown, and one sister, Gertrude Brown.

He was prepared at Union Classical Institute, now the Schenectady High School, and in 1901 received the degree of B.A. from Union College, Schenectady, N. Y. He was a member of Chi Psi.

He was married October 29, 1912, in Brookline, Mass., to Miss Marion Parker of Brookline, daughter of Retire Hathorn Parker and Caroline (Delano) Parker.

From 1904 to 1907 Brown served in the United States Forest Service. From 1907 to 1909 he was employed in the timber lands firm of James D. Lacey \& Company. Since January I, I9IO, he has been secretary and treasurer of the firm of Brown $\&$ Brown, Inc., dealers in timber lands, reports on timber properties and timber bonds.

Brown is a member of the Presbyterian church and of the University Club of Portland, Ore.

\section{Edward E. Carter \\ Petersham, Mass.}

Edward Edgecombe Carter was born October 7, 1880, in Bath, Maine, the son of Christopher O. Carter, a bank director and member of the city council, and Margaret E. (Edgecombe) Carter.

He prepared at the Bath (Maine) High School and before entering the Yale Forest School received the degree of B.A. at Bowdoin College in 1902 .

He was married October 22, 1907, in Bath, Maine, to Miss Helen L. Johnson of Bath, Maine, daughter of George W. Johnson and M. W. 
Johnson. They have a daughter, Margaret Carter, born January I9, I910, and a son, Edward Carter, born December 19, 1911.

Carter is assistant professor of forestry in the Harvard Forest School. From June to September, 1904, he acted as assistant in the Yale Forest School and from that time until June, 1905, was instructor in the Harvard Forest School. He was employed in the United States Forest Service from June, 1905, until September, I9I0, when he received his present appointment.

\section{Herman H. Chapman 360 Prospect Street, New Haven, Conn.}

Herman Haupt Chapman was born October 8, 1874, in Cambridge, Mass., the son of Frederic Lord Chapman and Ella Catherine (Haupt) Chapman, daughter of Herman Haupt, a civil engineer and railroad builder. He has three sisters: Lucy Lord Chapman, Eleanore Hassell Chapman and Marion Norton Chapman.

He received the degree of B.Sc. from the University of Minnesota in 1896 and in 1899 the degree of B.Agr. He was a member of Beta Theta Pi. Before entering the Yale Forest School he was superintendent of the Agricultural Experiment Station at Grand Rapids, Minn.

He was married December 29, 1903, in Duluth, Minn., to Miss Alberta Pineo of Duluth, Minn., daughter of Frank Pineo and Susan (Tupper) Pineo. They have two sons: Frederic Pineo Chapman, born March I4, 1905, and Edmund Haupt Chapman, born August 12, 1906; and one daughter, Ruth Chapman, born April II, I9ro.

Chapman spent the years 1904-06 in the United States Forest Service. In 1906 he was appointed instructor in the Yale Forest School and the next year became an assistant professor. Since I909 he has held the chair of Harriman professor of forest management.

$\mathrm{He}$ is a member of the Protestant Episcopal church. In politics he is a Progressive.

\section{Horace W. Chittenden}

Business address, Marine Bank Building, Buffalo, N. Y. Residence, 57 North Pearl Street, Buffalo, N. Y.

Horace Washburn Chittenden was born August 28, 1880 , in Washington, D. C., the son of George Benjamin Chittenden, Yale ' 7 I S., a mining engineer, and Ella Spencer (Delano) Chittenden. $\mathrm{He}$ is a nephew of 
Samuel Hosmer Chittenden, Yale ' $67 \mathrm{~S}$. He has two sisters: Mira D. (Chittenden) Bowman, wife of Morgan H. Bowman, Jr., Yale '05 S., and Marjorie L. Chittenden.

He was prepared at Columbian Preparatory School, Washington, D. C., and in 1903 graduated from the Sheffield Scientific School at Yale. While at college he was captain of the Freshman Baseball Team, a member of the Varsity Baseball Team and vice president of the Baseball Association. He was president of his Class in his Junior year, and a member of the Picture Committee, the Graduation Reception Committee and the Class Day Committee. He was a member of Delta Psi.

He was married October 10, 1908, in New Haven, Conn., to Katharine Panet Hastings, daughter of Charles Sheldon Hastings, Ph.D., Yale '7o S., and Elizabeth T. (Smith) Hastings. They have two daughters: Elizabeth Panet Chittenden, born July 16, 1909, in Cananea, Mexico, and Marjorie Lee Chittenden, born June 23, 1912, in New Haven, Conn.

Chittenden has been a mechanical engineer in the employ of the Lehigh Valley Coal Sales Company since May I, I9I2. He began work with the United States Forest Service in 1904, working in Tennessee, Georgia and Washington, D. C. Resigning from the Service in 1905 he went to Arizona, where he was employed by the Saddle Mountain Mining Company. In 1907 he went to Cananea, Mexico, where he was with the Greene Cananea Company until I909, with the exception of a few months when he was in the engineering department of the Copper Queen Consolidated Mining Company. On September 3, I909, he left Cananea to accept a position in the mining engineering department of the Lehigh Valley Coal Company on October 5, 1909, and resided in Wilkes-Barré, Pa., until April, I9I0, when he was transferred to the mechanical engineering department of the same company, and sent out on construction work. He lived at Pottsville, Pa., until March, I9I2, and spent two months on a farm in Connecticut before going to his present position in Buffalo.

$\mathrm{He}$ is a member of the Congregational church. $\mathrm{He}$ is a "Wilson Republican."

\section{Harold B. Eastman}

Business address, 494 Congress Street, Portland, Maine Home address, 343 Woodfords Street, Woodfords, Maine

Harold Benjamin Eastman was born June 24, 1878, in Portland, Maine, the son of Briceno Mendez Eastman and Martha (Clark) East- 
man. On his father's side he is of English and Welsh parentage, being the grandson of Benjamin Franklin Eastman, one of the founders of the Republican Party and a colonel of the Maine Regiment, and the great, great grandson of Joseph Dyer, one of the members of the Boston Tea Party. His mother's family was English and settled in Amesbury, Mass., in the seventeenth century. He has one brother, Fred Ermon Eastman, and two sisters: Carrie (Eastman) Richardson and Alice Clark Eastman.

He was prepared at the Deming High School and Maine Wesleyan Seminary and in 1902 received the degree of B.S. from Bowdoin College.

He was married October 18, 1905, in Bath, Maine, to Miss Bessie Watson Clifford of Bath, Maine, daughter of Charles W. Clifford and Addie Strout Clifford. They have one daughter, Martha Clifford Eastman, born September 8, I906, in Tacoma, Wash.

Eastman served as forest assistant in the United States Forest Service from the time of his graduation from the Yale Forest School until April, 1908. From then until August, 1909, he was employed by the St. John Lumber Company. In September, 1909, he became vice president and buyer for the firm of Eastman Brothers \& Bancroft, his present position.

$\mathrm{He}$ is a member of the Episcopal church. In politics he is a Progressive Republican. He is a Mason and a member of the Portland Athletic Club.

\section{Stuart J. Flintham}

Business address, 610 Loughlin Building, Los Angeles, Calif. Residence, III North Normandie, Los Angeles, Calif.

Stuart John Flintham was born December 30, 1879, in Albion, N. Y., the son of William S. Flintham.

He was prepared at the Albion (N. Y.) High School and studied at Williams College during the years 1899-1900 and 1900-or, and at the Cornell Forest School in $1901-02$ and 1902-03. In 1904 he received the degree of B.A. from Cornell University. He was editor of the college papers and member of the athletic teams at Williams and Cornell.

He was married November I4, 1907, in Orange, Calif., to Miss Helen Billingsley of Orange, Calif., daughter of Ray Billingsley and Eleanor Billingsley. They have one son, William B. Flintham, born August I7, 1908, in Los Angeles, Calif.

Flintham entered the United States Forest Service in June, 1904, resigned as forest inspector of California in July or 
August, 1908, and has since been engaged in business. He was forester and vice president of a forest planting concern from 1908 to I9II, when he entered the real estate business, his present occupation. He has also been forester of Los Angeles County, California, since IgII.

$\mathrm{He}$ is a member of the Universalist church. In politics he was "previously Republican, at present Progressive."

\section{Harold D. Foster}

Business address, United States Forest Service, Medford, Ore. Residence, 423 South Newtown Street, Medford, Ore.

Harold Day Foster was born February 12, I879, in Jersey City, N. J., the son of Addison Pinneo Foster (deceased), B.A. Williams '63, M.A. and D.D. '86, and Harriette (Day) Foster. His father was a Congregational clergyman and trustee of Berea College and Tuskegee Institute. $\mathrm{He}$ is the grandson on his father's side of Eden Burroughs Foster and Catherine (Pinneo) Foster, and on his mother's side of Pliny Butts Day and Harriette (Sampson) Day. He has two sisters: Mabel Grace Foster and Marion (Foster) Gribble, B.A. Mount Holyoke 'oo; and one brother, Winthrop Davenport Foster, B.A. Williams '04 and M.A. 'I2.

$\mathrm{He}$ was prepared at the Roxbury Latin School and the Newton (Mass.) High School and received the degree of B.A. from Williams College in 1902.

He was married December 20, I904, in Pownal, Vt., to Miss Elisabeth Hermon of Pownal, daughter of William Adams Hermon and Mary Ann (Rickards) Hermon. They have one son, Harold Day Foster, Jr., born June 5, 1907, at Walla Walla, Wash.

Foster has been employed as forest assistant in the United States Forest Service since July, I904. He writes: "One summer's work as student assistant in Maine in 1902 and one summer's work in the same capacity in California in 1903 in the Forest Service supplemented my technical education. In Maine I was cruising, in California mapping and gathering data on forest resources. My first assignment as forest assistant in the Service was in the Southern Appalachians, where I did much the same work as in California, but in addition collected silvical data and studied logging possibilities as the basis of an outline for forest management. After a year's detail in the Washington office, I was assigned to the Wenaha, the Whitman 
and the Crater National forests in Washington and Oregon, in turn. My work on the National forests was interrupted by special details in the Washington office and the district office at Portland, and as examiner of applications under the Act of June II, I906, in District 6. I have been for two seasons in charge of field parties engaged in making a map and a reconnaissance of the resources of the Crater National Forest in Oregon and much of my time has been spent as acting supervisor of the Crater Forest."

$\mathrm{He}$ is a member of the Congregational church and of the American Forestry Association and the Society of American Foresters.

He has published: The distillation of oil of wintergreen from black birch, For. and Irr., reprinted in The Pharmaceutical Era; (With W. W. Ashe) Chestnut oak in the Southern Appalachians, Circ., U. S. Forest Service.

\section{William B. Greeley}

Business address, United States Forest Service, Washington, D. C.

Residence, 625 Dahlia Street, Takoma Park, Washington, D. C.

William Buckhout Greeley was born September 6, 1879, in Oswego, N. Y., the son of Frank Norton Greeley, a Congregational clergyman, and Anna Cheney (Buckhout) Greeley. He had one brother, Arthur White Greeley, B.S. Leland Stanford, Jr., University '98, who died March 5, 1904

He was prepared at San Jose High School, San Jose, Calif., and received the degree of B.L. from the University of California in 190I, where he was a member of Phi Beta Kappa, Delta Upsilon and of the Order of the Golden Bear. Previous to this he was engaged in mountain ranching in California and after graduation from college he taught one year in the high school at Alameda, Calif.

He was married December 30, I907, in Berkeley, Calif., to Miss Gertrude Maxwell Jewett of Berkeley, daughter of Rev. Henry E. Jewett and Alice (Dwinell) Jewett. They have one daughter, Mary Jewett Greeley, born April 25, 1909, in Missoula, Mont., and a son, Arthur White Greeley, born August I, 1912, in Washington, D. C.

Greeley has been assistant forester in charge of silviculture in the United States Forest Service since June I, I908. He writes: "From July I, I904, to July I, 1905, I was engaged in 
commercial tree studies in the Southern Appalachians. July I, 1905, to November I, 1906, was inspector of timber sales in National forests in California. During that period, I directed the preparation of silvicultural working plans on portions of the Santa Barbara, Sequoia, Sierra and Tahoe National forests and supervised the marking and other timber sale activities on those forests. From November I, 1906, to May I, 1908, I had charge, as supervisor, of the Sequoia National Forest, California, area over three million acres. The work was chiefly organization of the administrative force and of fire protection in a vast, inaccessible, mountainous region."

$\mathrm{He}$ is a member of the Society of American Foresters and of the Graduate Advisory Board of the Yale Forest School.

He has written: (With W. W. Ashe) White oak in the Southern Appalachians, Bull. U. S. Forest Service, about Jan. I, 1906 .

\section{Walter B. Hadley}

Redlands, Calif.

Walter Brooke Hadley was born September 7, 1877, in Dayton, Ore., the son of William Macy Hadley and Harriet (Fuson) Hadley. His father graduated from Earlham College, Richmond, Ind., in both the classical and scientific courses, was a professor of languages and sciences and held many positions of public trust. On his father's side he is of English ancestry, being the grandson of Thomas Hadley and Lucinda (Macy) Hadley, both Quakers of early colonial stock. On his mother's side he is of English and Welsh descent. He has two brothers: Ellis Fuson Hadley and Louis F. Hadley; and one sister, Elizabeth Macy (Hadley) Newhouse.

He was prepared at the public schools of Dayton, Ore., and at the Academy, Newberg, Ore. In Igor he received the degree of B.S. from Pacific College, after which he took one year's commercial work at McMinnville College, McMinnville, Ore.

He was married September 30, 1907, in McMinnville, Ore, to Miss Amba Irene Daniels of McMinnville, daughter of Charles Franklin Daniels and Malissia Minerva (Kuns) Daniels. They have one daughter, Mildred May Hadley, born March 19, 1909. A son, Macy Daniels Hadley, born October 29, I910, died November II, 1910.

Hadley was employed as forest assistant in the United States Forest Service from July I, 1904, to September 15, 1908. Since leaving the Service he has been in very poor health, which has 
prevented activities of any kind. $\mathrm{He}$ is at present engaged in horticulture in Redlands, Calif.

$\mathrm{He}$ is a member of the Friends (Quaker) church and in politics is a Progressive Republican. He is a member of the Independent Order of Odd Fellows and also holds Rebekah and Encampment degrees.

\section{Ralph C. Hawley}

Business address, 360 Prospect Street, New Haven, Conn.

Ralph Chipman Hawley was born March 5, I880, in Atlanta, Ga., the son of Chester Warren Hawley and Martha (Jaqueth) Hawley. He has one brother, Edwin C. Hawley, B.A. Amherst 'or, and D.D. Auburn Theological Seminary 'o4.

He was prepared with tutors and received the degree of B.A. at Amherst College in I90I.

He was married September 15, 1910, in New Haven, Conn., to Miss Mary Minor of New Haven, Conn., daughter of Alfred W. Minor. They have one son, Alfred Minor Hawley, born July 19, I9II, in New Haven, Conn.

Hawley has been a teacher of forestry at the Yale Forest School since 1909. Previous to this he held the positions of forest assistant in the United States Forest Service and assistant state forester in the Massachusetts Forest Service.

$\mathrm{He}$ is a member of the Congregational church. In politics he is progressive. He is a member of the Society of American Foresters and of the Graduates Club of New Haven.

He has published: (With A. F. Hawes) Forestry in New England, N. Y., Wiley \& Sons, I9I2, 8vo, XV + 479 pp., I40 figs., 2 maps.

\section{Paul D. Kelleter}

Deadwood, S. Dak.

Paul Delmar. Kelleter was born May I, I88I, in St. Louis, Mo., the son of Carl Kelleter and Pauline Josephine (Thomas) Kelleter. His father was a native of Aix-la-Chapelle, Germany, and his mother of Belleville, Ill.

He was prepared at the St. Louis High School, St. Louis, Mo., and in 1902 received the degree of B.A. from Washington University, St. Louis. 
He was married October 21, 1908, in Washington, D. C., to Miss Lucy Taber Pool of Washington, D. C., daughter of Dr. Benjamin George Pool. They have a daughter, Helen Kelleter, born December 31, 1910, in Washington, D. C., and a son, Paul Kelleter, born August 8, 1912, in Deadwood, S. Dak.

Kelleter is forest supervisor in the United States Forest Service with headquarters in Black Hills National Forest, Deadwood, S. Dak., which position he has held since March I, 1909. He was forest assistant in the Service from July I, 1904, to January I, 1908, when he became chief of the division of settlement. On October I, 1908, he was appointed acting chief of the office of lands and remained in this position until December I, I908. During I9I0 and I9I I he was chairman of a board organized to effect the exchange of South Dakota school lands and represented the Forest Service on this board.

$\mathrm{He}$ is a member of the Episcopal church. He is a member of the Society of American Foresters and of the American Forestry Association. He is a $32^{\circ}$ Mason, a Shriner and a member of the Concatenated Order of Hoo-Hoo.

He has published: (With A. W. Cooper) Control of forest fires at McCloud, Calif., Bull. 79, U. S. Forest Service, 1906.

\section{Charles A. Lyford \\ 520-524 Vancouver Block, Vancouver, B. C., Canada}

Charles Albert Lyford was born October 19, I882, in Waverly, N. Y., the son of Frederic Eugene Lyford, president of the First National Bank of Waverly, N. Y., and Cora (Lowman) Lyford. He has two brothers: Percy Lang Lyford, B.S.A. Cornell ' 66 , and Frederic Eugene Lyford, Jr.; and two sisters: Winifred Lyford and Katharine Lyford.

He was prepared at the Waverly (N. Y.) High School and received the degree of F.E. from Cornell University in I904.

$\mathrm{He}$ is unmarried.

Lyford is a partner in the forest engineering firm of Clark \& Lyford, which has headquarters in Vancouver, B. C., Montreal, Que., and Philadelphia, $\mathrm{Pa}$., and which was organized in February, 1910. He was at one time forest assistant in the United States Forest Service, after which he became general manager 
of the Eastern Lumber Company, Huttonsville, W. Va., and later forester for the Riordan Paper Company, Montreal, Canada.

\section{Wilbur R. Mattoon}

Business address, United States Forest Service, Washington, D. C.

Residence, The Winston, Mt. Pleasant Street, Washington, D. C.

Wilbur Reed Mattoon was born August 14, 1875, in Harwich, Mass., the son of Virgil Wadhams Mattoon, a clergyman of the Methodist Episcopal church, and Mary Frances (Reed) Mattoon. He is the grandson on his father's side of Plyment Mattoon, a Scotchman, and Tryphena (Parker) Mattoon, and on his mother's side of Marvin John Reed and Eunice Ann (Heath) Reed. He has one brother, Howard V. Mattoon, B.A. Wesleyan University ' $\infty$, and one sister, Florence A. (Mattoon) Bass.

He was prepared at the Cazenovia (N. Y.) Seminary and received the degree of B.A. at Wesleyan University in 1899 . He taught science in the high school at Kalamazoo, Mich., for three years and studied forestry one year at Cornell University before entering the Yale Forest School.

He was married August 28, 1909, in Tyrone, N. Y., to Miss Kate Van Liew of Las Vegas, N. Mex., daughter of Edson Van Liew and Mary (Sunderland) Van Liew. They have one son, Richard Wilbur Mattoon, born February 8, 1912.

Since entering the United States Forest Service Mattoon has held successively the positions of forest assistant, assistant forest inspector, inspector, forest examiner and forest supervisor. In 1905-07 he established Fort Bayard Nursery. He was inspector of District 3 from 1907 to December, 1908, and chief of silvics, District 3, in 1908-09. In 1909-10 he was forest supervisor of Manzano National Forest and in I9ro-I2 of Manzano and Zuñi National forests. Since 1912 he has been employed in the office of silviculture, Washington, D. C.

$\mathrm{He}$ is a member of the Presbyterian church. $\mathrm{He}$ is a member of the Society of American Foresters and of the American Forestry Association.

He has published: Chestnut sprouts, origin and early development, For. Quart., I909; Measurement of the effect of forest cover upon the conservation of snow waters, For. Quart., 1909. 


\section{Hamilton G. Merrill \\ United States Forest Service, Santa Barbara, Calif.}

Hamilton Griswold Merrill was born July 18, 1878, in Andover, Mass., the son of George Cooke Merrill and Florence (Adams) Merrill. He is the grandson on his father's side of James H. Merrill and Lucia W. G. Merrill, and on his mother's side of Isaac Adams and Nancy H. Adams. He has one sister, Florence (Merrill) Featherston, B.A. Smith '98.

He was prepared at Phillips Academy, Andover, Mass, and received the degrees of B.A. and M.A. at Amherst College in 1900 and 1905, respectively.

He was married January I, 1913, in Santa Barbara, Calif., to Miss Helen Inez Eschenburg of Santa Barbara, daughter of Arnold W. Eschenburg (deceased), and Mary M. Eschenburg.

Merrill is deputy forest supervisor in the United States Forest Service with headquarters in Santa Barbara, Calif. He has held this position since July I, I904. He writes: "Have been in the Bureau of Forestry and the Forest Service continuously. Have traveled some in the South and West."

\section{Allan B. Patterson \\ Business address, Hot Springs, Tulare Connty, Calif. \\ Home address, Concord, N. H.}

Allan Bouton Patterson was born January 22, 1875, in Concord, N. H., the son of Joab Nelson Patterson and Sarah, (Bouton) Patterson. His father was colonel of the Ist New Hampshire Volunteers in the Civil War, captain of the 2d New Hampshire Volunteers in the Spanish War and quartermaster of the 3d Division Ist A. C. He was also United States marshal, 2d auditor of the Treasury, superintendent of Public Buildings, Cuba, and is at present United States Pension Agent. An antecedent on his mother's side, Nathaniel Bouton, received the degree of B.A. from Yale in 1821 and the degree of D.D. from Dartmouth in 185I. He has one sister, Julia Nelson Patterson, and one brother, Louis Marston Patterson.

He was prepared at Phillips Andover and in 1898 received the degree of Ph.B. from Dartmouth College. From April 9 to November 20, I898, he served as a private in the Ist New Hampshire Volunteers and in the 3d Division, Ist A. C. Hospital Corps. He was employed in the General Electric Company a year and a half before entering the Yale Forest School.

$\mathrm{He}$ is unmarried. 
Patterson is forest supervisor in the United States Forest Service with headquarters in Sequoia National Forest, California. From July I, 1902, to June 30, I904, he was employed as student assistant in the Service, after which he became forest assistant. This appointment he held until December 31, 1906. $\mathrm{He}$ was appointed special agent of the Bureau of Corporations on August 15, 1907, and on May I, 1908, he became chief of the office of federal coöperation, which position he held until his present appointment, January 24, 1910.

$\mathrm{He}$ is a member of the Episcopal church and in politics is a Progressive Republican. He is a member of the Society of American Foresters and of the Sierra Club:

\section{Allan R. Powers, M.D.}

Business address, Southern Pacific Hospital, San Francisco, Calif. Home address, 2009 Buchanan Street, San Francisco, Calif. III Ellis Street, San Francisco, Calif.

Allan Raymond Powers was born May 23, I88I, in San Rafael, Calif., the son of George Herman Powers, B.A. Harvard '6r, M.D. and M.A. '65, and Cornelia Jeanette (Chapman) Powers. His father served in the 23d Massachusetts in the Civil War as surgeon. He is the grandson on his mother's side of Russell Chapman and Maria (Ives) Chapman. He has one brother, George H. Powers, Jr., B.L. University of California '98 and M.D. '02, and two sisters: Ruth Powers and Katherine Powers.

He was prepared at Selbourne School, San Rafael, Calif., and received the degree of B.S. from the University of California in December, I90I. He spent the year I902-03 at Cornell University at the New York State School of Forestry. At college he was a member of Sigma Alpha Epsilon, Theta $\mathrm{Nu}$ Epsilon and Skull and Keys.

$\mathrm{He}$ is unmarried.

From 1904 to 1907 , and again in the summer of 1908, Powers was technical assistant in the United States Forest Service. In 1909 and I9Io he was cruiser for the Southern Pacific Railroad Company. He writes: "In August, 1907, gave up forestry to study medicine, to go into business with my father. Spent three years at the University of California and the last two at Cooper Medical College [San Francisco], graduating in May, I9I2." On May 15, 1912, he was appointed interne in the Southern Pacific Hospital, San Francisco, Calif. 
Powers is an Episcopalian. In politics he is a Republican. $\mathrm{He}$ is a member of the National Geographic Society, the American Medical Association and the California Fish and Game Commission.

\section{Paul G. Redington}

\section{Northfork, Madera County, Calif.}

Paul Goodwin Redington was born January 25, 1878, in Chicago, Ill., the son of Edward Dana Redington, Dartmouth '6r, and Mary (Chamberlain) Redington. His father was second lieutenant of the 12th Vermont Regiment in 1862, junior paymaster with rank of major in $1863-64$, senior vice-commander of the Military Order of the Loyal Legion, Chicago Commandery and commander of the John A. Logan Post, G. A. R., Evanston, Ill., and was also a trustee of Dartmouth College from I895 to I905 and author of the "Dartmouth Roll of Honor" in the Civil War. He is the grandson on his father's side of E. C. Redington and Caroline (Stearns) Redington and is of English ancestry. He has one sister, Lizzie Stearns Redington, and two brothers: John Chase Redington, B.A. Dartmouth 'oo, and Theodore Towne Redington, B.A. Dartmouth 'o7.

He was prepared at the Evanston Township High School and received the degree of B.A. from Dartmouth College in 1900. From the fall of 1900 to the spring of 1902 he worked in the credit department of J. T. Ryerson \& Son, Chicago, Ill.

He was married September 21, I9Io, in Denver, Colo., to Miss Ermina Weaver of Denver, daughter of Alonzo Benton Weaver and Ann May (Sammis) Weaver.

Redington has been employed in the United States Forest Service since graduating from the Yale Forest School, during which time he has held the following positions: forest assistant, I904-05; forest inspector, I906; inspector, 1907-08; assistant district forester, I909; associate district forester, I9IO; and supervisor, I9I I to the present time. His headquarters are in Northfork, Sierra National Forest, California.

$\mathrm{He}$ is a member of the Congregational church and in politics is a Progressive Republican. He is a member of the Society of American Foresters, the American and Colorado Forestry associations, the Sierra Club and the Dartmouth Alumni Association of California. 


\section{Avery T. Searle}

Business address, Care of Hawkins \& Pierce, Brownsville, Texas Residence, Brownsville, Texas

Avery Turner Searle was born July 28, I869, in Brookfield, Mo., the son of Luman B. Searle and Susan (Turner) Searle. His father was a native of New York and was a teacher in the public schools in Illinois, Missouri and Chattanooga, Tenn. His mother was born in Massachusetts and was the daughter of Avery Turner.

$\mathrm{He}$ received the degree of B.A. from Pomona College in 1806 and afterward attended the University of California. During the year 1897 he studied law with a private tutor at Oakland, Calif., and was admitted to the Bar by the commissioners of the Supreme Court on December 29, 1897. Before entering the Yale Forest School he taught in high schools in California and in a private school in Honolulu, Hawaii.

He was married September 20, I903, in Lodi, Calif., to Miss Emily D. Colman of Lodi, daughter of Dr. Frederick W. Colman and Emily W. Colman. They have twins: Edward T. C. Searle and Eleanor C. Searle, born July 8, 1907. A daughter, Margaret Searle, born July 28, 1904, in Pasadena, Calif., died June 8, I912, in Brownsville, Texas; and another, Dorothy C. Searle, born September 5, 1905, in Pasadena, died October I0, 1910, at San Francisco, Calif.

After graduation from the Yale Forest School Searle was appointed assistant to Mr. Lukens in reforestation in the Sierra Madre Mountains, Southern California. He left this position, however, and became assistant manager of the Oak Knoll Tract, Pasadena, Calif. Upon the completion of this work he was for a time engaged in law practice in Lodi, Calif., and later went to Texas, where he held the position of assistant general manager of the Kilgore Plantations at Mercedes and Harlingen. Since March 18, 1912, he has been assistant in the law office of Hawkins \& Pierce in Brownsville, Texas.

$\mathrm{He}$ is a member of the Congregational church and in politics is a Progressive Republican. He is a member of the Knights of Pythias and of the Modern Woodmen of America.

\section{Clinton G. Smith}

\section{Logan, Utah}

Clinton Gold Smith was born September 16, 1879, in North Cornwall, Conn., the son of Walter Dodge Smith and Mary Louise (Coe) Smith 
(died in 1888). His father was a merchant in Litchfield, Conn., prior to 1886, and from I 888 to 1908 was business manager of Atlanta University, Atlanta, Ga. Several of his paternal ancestors fought in the Revolution. He has one sister, Mrs. George Knight Howe.

He was prepared at the Litchfield High School and received the degree of B.Agr. from Storrs (now Connecticut) Agricultural College in 1898, where he was second lieutenant in the cadet corps. He entered the Division of Forestry in 1900 and was assigned to various field parties in Georgia, North Carolina and Tennessee, in Minnesota and California, the latter assignment being while he was a student in the Yale Forest School.

He was married February 17, 1909, in Springfield, Ill., to Miss Margaret Alice Young of Springfield, Ill., daughter of Robert Young and Laura Jane (Irwin) Young.

Smith has been forest supervisor in the United States Forest Service since August I, 1908, with headquarters during that year in Pocatello National Forest, Pocatello, Idaho, and since I909 in Cache National Forest, Logan, Utah. He entered the Service in 1904 as forest assistant and was engaged in the study of redwoods in California. In 1905-06 he acted as technical assistant in Medicine Bow National Forest, Wyoming, and in 1907-08 held the same position in Weiser and Boise National forests, Idaho. Aside from his prescribed duties, he has been interested in a variety of projects. While at Logan he has been engaged in the establishment of a course of study for forest rangers at the Utah Agricultural College and has delivered a course of lectures there. He has secured gratifying results through the sanitation of Logan River Watershed, bringing the local Board of Health into coopperation with the Forest Service. He is interested in the application of the principles of scientific management to his work, and has prepared two original papers on that subject. He is the author of numerous reports on silvical subjects. In timber reconnaissance he completed a portion of the Weiser Forest and initiated similar work on the Pocatello and Cache National forests. $\mathrm{He}$ is a member of the District Investigative Committee of the Forest Service.

$\mathrm{He}$ is a member of the Congregational church. He is a member of the Society of American Foresters, the Commercial Boosters Club of Logan, Utah, and is a Mason. 


\section{Thomas J. Taylor}

Thomas Jackson Taylor was born in Montgomery City, Mo., in 1872. $\mathrm{He}$ attended Missouri University and received the degree of B.A. at Chicago University in 1894 .

He was married about 1903.

Upon graduation from the Forest School Taylor entered the Bureau of Forestry, being engaged in the establishment of nurseries on the Pike's Peak Reserve. He later entered the real estate business. It has not been possible to secure his present address.

\section{Blaine S. Viles}

\section{Augusta, Maine}

Blaine Spooner Viles was born July 22, 1879, in New Portland, Maine, the son of Edward Payson Viles and Ada Augusta (Spooner) Viles. His father has held the positions of postmaster of North New Portland, Maine, sheriff of Somerset County, Maine, chairman of the Somerset County Republican Committee, president of the Dead River Log Driving Company and of the Dead River North Branch Log Driving Company. On his father's side he is of English descent, the grandson of Rufus Viles. His mother's parents were Lamont and Caroline Spooner.

He was prepared at the Skowhegan High School, North New Portland, and received the degree of B.A. with the Class of 1903 at Bowdoin College, where he was a member of Delta Kappa Epsilon.

He was married June 30, 1904, in Hallowell, Maine, to Miss Annie Ethel Johnson of Hallowell, Maine, daughter of William C. Johnson and Annie H. Johnson. They have one daughter, Dorothy Viles, born May 28, I905, in Newport, N. H., and one son, William PaysonoViles, born July 16, 1906, in Newport, N. H.

Viles is at present engaged in private forestry work in Augusta, Maine, and is also forester and superintendent of the Blue Mountain Forest Association (Corbin Game Preserve) of New Hampshire. He was employed in the United States Forest Service for two summers and in 1908 moved to Augusta to engage in forestry work in connection with lumbering operations carried on by his father. In July, I9I0, he was appointed a member of the Fish and Game Commission of the State of Maine and in January, I913, he became state forest commissioner and land agent of Maine. The latter position has never before 
been held by a technical forester. $\mathrm{He}$ is also chief fire warden of the Maine Forestry District.

In politics he is a Republican. He is president of the Republican Club of Augusta and since 1912 has been a member of the Augusta Republican City Committee. $\mathrm{He}$ is a member of the Society of American Foresters, the American Fisheries Society, the American Bison Society; also B. P. O. E., Masonic Orders, including Mystic Shrine, the Abnaki Club and the Augusta Yacht Club.

\author{
William G. Weigle \\ Business address, Ketchikan, Alaska \\ United States Forest Service, Washington, D. C.
}

William Grant Weigle was born September 20, 1866, in Bendersville, Pa., the son of Henry B. Weigle and Anna Mary (Meals) Weigle. He has one brother, Samuel Harvey Weigle.

His boyhood was spent on a farm and he later attended the Pennsylvania State Normal School. From 1896 to 1899 he was principal of schools in Cornwall, $\mathrm{Pa}$., and from 1899 to I90I held the same position in Steelton, $\mathrm{Pa}$. In $1901-02$ he was engaged as a railway mail clerk.

$\mathrm{He}$ is unmarried.

Weigle is forest supervisor of the Chugach and Tongass National forests of Alaska in the United States Forest Service. $\mathrm{He}$ has held this position since I9II. In I904 he acted as field assistant in the Service and in 1905 was superintendent of the wood department of the Pennsylvania Paper Mills, Bloomsbury, $\mathrm{Pa}$. In 1906 he was made assistant forest inspector in the Service, in 1907 assistant chief of forest management, in 1908 assistant chief of state and federal coöperation and in I909 forest supervisor of the Coeur d'Alene National Forest.

$\mathrm{He}$ is a member of the Lutheran church and in politics is a Progressive. $\mathrm{He}$ is a member of the National Geographic Society, the American Forestry Association, the Society of American Foresters, the Arctic Brotherhood and the Concatenated Order of Hoo-Hoo.

He has published: (With E. H. Frothingham) The aspens, Bull. 93, U. S. Forest Service. 


\section{Robert B. Wilson \\ Medford, Ore.}

Robert Bruce Wilson was born June 2, 1877 , in Portland, Ore., the son of Robert Bruce Wilson, M.D. University of Virginia '49 (deceased), and Caroline Elizabeth (Couch) Wilson. His father was born in Portsmouth, Va., and his mother in Newburyport, Mass. He has two brothers: Holt C. Wilson, M.D. University of Virginia ' 76 , and George F. Wilson, M.D. University of Virginia '79; and four sisters: Mary Caroline Burns, Clementine Wilson, Virginia Wilson, and Maria Louise Linthicum.

He was prepared at Lawrenceville School, Lawrenceville, N. J., and at Portland Academy, Portland, Ore, and graduated from Yale College in I90I.

$\mathrm{He}$ is unmarried.

After graduation from the Forest School, Wilson entered the United States Forest Service. He resigned from the Service in March, 1908, at which time he held the position of supervisor of the Cascade National Forest. In 1907 he had purchased an apple and pear orchard in Rogue River Valley, Ore., and since he left the Service has been a rancher and fruit-grower there.

In politics he is a Progressive.

\section{Graduates holding Certificate but not Degree}

\section{William H. Kobbé}

Business address, Shale, Calif.

Home address, 116 South Grand Avenue, Pasadena, Calif.

William Hoffman Kobbé was born January 22, 188I, in Fort Hamilton, N. Y., the son of William August Kobbé and Isabella (Hoffman) Kobbé. His father attended college and mining academies in Germany, served during three years of the Civil War from the position of private to that of captain and afterwards in regular service as officer in all grades to and including major general. He was also military governor of Mindanao and Jolo, Philippine Islands, and retired in 1904. His father's parents were William August Kobbé and Sarah Lord (Sistare) Kobbé of Nassau, Germany, and New York, respectively, and his mother's parents were William Hoffman, brevet major general in the United States Army, and Isabella (Simpson) Hoffman. $\mathrm{He}$ has three brothers: Ferdinand Walter 
Kobbé, captain of the 22d Infantry, U. S. A., Herman Kobbé, Ist U. S. A., and Eric Kobbé, and one sister, Sarah Kobbé.

He was prepared in the public schools of San Francisco, Calif., and attended the Biltmore Forest School before entering the Yale Forest School.

He was married March 6, 1912, in Pasadena, Calif., to Miss Mary Ckatherine Mather of Pasadena, daughter of Thomas Wylie Mather and Mary Elizabeth Saxe (Maclay) Mather.

Kobbé served as district forester under the civil government of the Philippine Islands from November, I904, to December, 1907. He was transferred in 1908 to the United States Forest Service as forest assistant and stationed in Arizona for two years. In I910 he became foreman of the Globe Exploration Company, oil producers, and in the same year was made surveyor of this company. In I9II he was appointed superintendent of the Rock Oil Company and later in this year received the appointment of superintendent of the Globe Exploration Company. On September 18, 1912, he accepted the position of division superintendent of the General Petroleum Company.

$\mathrm{He}$ writes: "Had charge of the provinces of Batanzas, Tayabas, Albay, Sorsogon, Camarines Norte, Camarines Sur and the little-known island of Mindoro in the Philippines and did considerable exploring and mapping during the three years spent there. Saw something of Japan and took the opportunity to travel by land from Nagasaki to Kobe. Upon returning to the United States spent nearly two years in different parts of Arizona, but found government service there distasteful and for the most part poorly paid. Have been in the oil business in California for nearly three years, starting as a 'roustabout' and having held about every position up to superintendent. The work is interesting, out-of-doors, mostly mechanical and in very congenial surroundings."

$\mathrm{He}$ is a member of the Episcopal church and in politics is a Progressive Republican. $\mathrm{He}$ is a member of the California Academy of Sciences, of the American Ornithologists Union, the Cooper Ornithological Club, the Overland Club of Pasadena, Calif., and the Yale Alumni Association of Southern California.

$\mathrm{He}$ has written numerous technical articles for the Auk (official organ of the Am. Ornith. Union) and the Condor (Cooper Ornith. Club of Calif.). 


\section{Manasseh Smith, Jr.}

Business address, American Eucalyptus Timber Corporation, Chicago, Ill. Home address, 252 Woodfords Street, Portland, Maine

Manasseh Smith, Jr., was born January II, I880, in Radnor Forges, Que., Canada, the son of Manasseh Smith and Georgiana W. (Hall) Smith. He has six sisters: Georgiana M. Smith, Gertrude Smith, B.A. Vassar '97 and M.A. '03, Katharine B. Smith, Helen G. Smith, Ruth P. Smith, B.A. Vassar '05, and Bertha H. Smith; and one brother, Ralph E. Smith.

He was prepared at the Portland (Maine) High School and from 1900 to 1903 attended Cornell University.

$\mathrm{He}$ is unmarried.

Smith is forester and field manager for the American Eucalyptus Timber Corporation, Chicago, Ill. From July, r904, to April, 1907, he was forest assistant in the United States Forest Service, and from May, 1907, to July, I910, was assistant state forester of California. He has held his present position since September I, I9I0.

$\mathrm{He}$ is an Episcopalian. In $\mathrm{I} 898$ he was a private in the Ist Maine Volunteer Infantry.

\section{Non Graduates}

\section{Frank P. Hamilton}

Business address, 300 Law Exchange Building, Jacksonville, Fla.

Residence, 1716 Simmons Street, Jacksonville, Fla.

Frank Percival Hamilton was born August 20, 188I, in Gloucester, Mass., the son of Robert Stevenson Rice Hamilton, who was a member of the firm of R. S. Hamilton \& Company, general commission merchants, of Boston, Mass., and Alice M. (Barton) Hamilton (died in 1883). His parents were married in 1879. His father was born in Liverpool, Nova Scotia, the son of Samuel Vinton Hamilton and Mary Moore (Page) Hamilton of Nova Scotia and grandson of Samuel Vinton Hamilton, who was in the British army in the War of $18 \mathrm{r} 2$ and settled afterwards in Nova Scotia. His mother was born in West Windsor, Maine, the daughter of Gideon Barton and Harriet (Percival) Barton and great-granddaughter of Stephen Barton, a surgeon in the American army during the war of the Revolution, and a member of the same family as Clara Barton, founder of the American Red Cross Society. 
He was prepared at Oak Grove Seminary, Vassalboro, Maine, and in 1902 received the degree of B.A. from Colby College, where he was a member of Delta Upsilon.

He was married May 1, I913, in Jacksonville, Fla., to Miss Elizabeth Legére Fleming of Jacksonville, a graduate in 1900 of the Stuart School of Washington, D. C., daughter of Francis Philip Fleming (deceased), formerly governor of Florida.

Hamilton studied at the Harvard Law School in $1903-04$ and spent the year of 1905 ranching in Arizona. In 1908 he received the degree of LL.B. from Denver University and since October of that year has been clerk in the law firm of Fleming \& Fleming of Jacksonville, Fla. He writes: "Since leaving Yale and until IgIo the interval has been entirely devoted to study and to search for health. Travels for health's sake have involved trips to and residences in Arizona, New Mexico, California, Colorado and most of the western states, and in Arkansas at Hot Springs."

Of his politics he writes that he is a "Democrat, but hardly a pure Jeffersonian." $\mathrm{He}$ is a member of the Florida Country Club and the Seminole Club.

\section{Wilbur F. Henderson}

Box 145, Manchester, N. H.

Henderson is engaged in farming.

\section{Yukichi Hokodachi}

Yukichi Hokodachi entered the Yale Forest School from the Middle School of Japan and took all the regular courses at the School with the exception of those given in the spring term, Senior year. It has not been possible to secure his present address.

\section{Richard P. Imes}

Business address, Custer, S. Dak.

Home address, Spearfish, S. Dak.

Richard Perry Imes was born November 4, 1878, in Springfield, Mo., the son of Richard Perry Imes and Eliza Esther (Reynolds) Imes. His father, who was of German ancestry, was a farmer and was a scout 
and soldier in the Civil War. He has one brother, Carl Imes, a graduate of the South Dakota State Normal School. A sister, Jennie May Imes, is now deceased.

Before entering the School he was graduated from the South Dakota State Normal School and was for two years student assistant in the Division of Forestry.

He was married December 31, 1903, in Lincoln, Neb., to Miss Hanna Charlotte Christiansen of Spearfish, S. Dak., daughter of H. J. Christiansen. They have one son, Richard Perry Imes, born August 24, I906, in Deadwood, S. Dak., and one daughter, Karen Charlotte Imes, born November 5, 1903, in Ogden, Utah. A daughter, born June 16, 1905, died the same day.

Imes has been continuously in the United States Forest Service since leaving the Yale Forest School. He was forest assistant from 1903 to 1905 and forest inspector from 1905 to 1908. In 1909 he was appointed chief of operation, District 4, and since I9ro he has been supervisor of the Harney National Forest, South Dakota, with headquarters at Custer.

$\mathrm{He}$ attends the Congregational church and in politics is a Bull Moose. He is a member of the Masonic Lodge of Custer, S. Dak., and of the Ogden Business Men's Club of Ogden, Utah.

\section{*Louis C. Miller}

\section{Died I9I0}

Louis Christian Miller was born in 1873 in Joplin, Mo.

He received the degree of B.S. in IgOr at the Oklahoma Agricultural and Mechanical College and before entering the Forest School was registered for one year in the graduate department of the Sheffield Scientific School. He took the courses of Junior year in the Forest School.

Miller entered the Bureau of Forestry immediately after leaving the Forest School, served first as a forest assistant, and later became field assistant in the section of which he later became chief. In the Forest Service he had devoted himself to work directly connected with forest extension and he was recognized as an expert in planting. At the time of his death he was chief of the section of planting in District 2.

He died at Denver, Colo., on July I6, I910, following an operation for appendicitis. 


\section{CLASS OF 1905 \\ Graduates holding Degree of M.F.}

\section{J. Fred Baker}

Michigan Agricultural College, East Lansing, Mich.

James Fred Baker was born April 20, 1880, in Saint Croix Falls, Wis., the son of Joseph Stannard Baker and Alice (Potter) Baker. For further family history see biography of H. P. Baker, M.F. '04

He was prepared at McAllister Academy, St. Paul, Minn., and was graduated with the degree of B.S. at Michigan Agricultural College in I902.

He was married April 20, 1907, in Wayland, Mich., to Miss Bessie Buskirk, daughter of H. F. Buskirk.

Upon graduation in 1905 Baker entered the United States Forest Service as forest assistant but he has given most of his time to teaching. His first position was as instructor in the Pennsylvania Forest Academy at Mont Alto, Pa. Later he became assistant professor of forestry at the Colorado School of Forestry, Colorado College, Colorado Springs, and since 1907 he has been professor of forestry at the Michigan Agricultural College, East Lansing, Mich. The latter college conferred upon him the degree of M.For. in I9II.

$\mathrm{He}$ is a member of the Presbyterian church.

\section{John E. Barton}

Business address, State Forester, Frankfort, $K y$.

Residence, 417 Capitol Avenue, Frankfort, Ky.

John Earle Barton was born February 12, 1879, in Warren, Mich., the son of Arthur Oliver Barton and Julia Alma (Hoxsey) Barton. Both parents are of English descent, their ancestors having come to this country previous to the Revolutionary War. He has one sister, Helen Margaret Barton, and a brother, Louis Arthur Barton, who was graduated at the University of Michigan in 1903.

He was prepared in the public and high schools of Detroit, Mich., and was graduated from the University of Michigan in 1902. 
He was married January 19, 1908, in Kuttawa, Ky., to Miss Mabel Leech Glenn, daughter of Thomas Glenn, deceased, and Lillian (Huggans) Glenn. They have two sons: David Glenn Barton, born November 24, I908, in Princeton, Ky., and John Earle Barton, Jr., born October I9, 1910, in Sandpoint, Idaho.

Barton was with the Federal Government until September, I9I2, when he became state forester of Kentucky. Previous to that time, since 1908, he had been forest supervisor with headquarters at Sandpoint, Idaho.

\section{Anton T. Boisen}

Business address, Department of Church and Country Life, Presbyterian Board of Home Missions, I56 Fifth Avenue, New York City

Home address, 307 East Second Street, Bloomington, Ind.

\section{Ames, Iowa}

Anton Theophilus Boisen was born October 29, 1876, in Bloomington, Ind., the son of Hermann Balthazar Boisen and Louise (Wylie) Boisen, daughter of Theophilus Adam Wylie, professor of physics and vice president of Indiana University, I836-1887. Hermann B. Boisen was a professor of modern languages at Indiana University from 1870 to 1880 , and master of modern languages at Lawrenceville School from 1883 until his death the following year. He was the son of Amtsrichter Johannes Boisen of Sonderberg, Alsace, Schleswig, Germany. A sister, Marie Louise (Boisen) Bradley, was graduated at Indiana University in 1900 .

He was prepared at the Bloomington High School, Bloomington, Ind., and received the degree of B.A. at Indiana University in 1897 . He was an instructor in romance languages at that institution from 1898 to 1903 . He was a member of Phi Gamma Delta.

He is unmarried.

Boisen served as a forest assistant in the United States Government Service from 1905 to 1908 , resigning to take up preparation for the ministry at the Union Theological Seminary in New York City. He remained there three years, receiving a diploma in I9I I and during the next year was engaged as a field investigator in the department of church and country life of the Presbyterian Board of Home Missions. In 1912 he was appointed Congregational University pastor at the State College, Ames, Iowa. 
$\mathrm{He}$ is a National Progressive in politics.

He has published: The commercial hickories, Bull. U. S. Forest Service; Rural survey in Missouri, Department of Church and Country Life, Presbyterian Board of Home Missions.

\section{Harold R. Bristol}

Box 186, Plattsburgh, N. Y.

Harold Russell Bristol was born December 18, 1878, in Meriden, Conn., the son of Walter Reuben Bristol and Iva Louise (Turner) Bristol, who were both descended from early Colonial stock, the Turners being early settlers at Guilford, Conn. A brother, Howard Stanley Bristol, was graduated at Yale with the Class of 'o2 S., and received the degree of $\mathrm{Ph} . \mathrm{D}$. in 1905 at Yale.

He prepared at Riverview Academy and Portland Academy, Portland, Ore., and received the degree of F.E. at Cornell in June, 1904.

He was married June 15, 1905, in Poughkeepsie, N. Y., to Miss Maud Campbell McGlasson, of Pawling, N. Y., daughter of John McGlasson and Olivia (Hurd) McGlasson. They have two children: Donald McGlasson Bristol, born April 7, 1906, in St. Martins, New Brunswick, Canada, and Dorothy Olivia Bristol, born September 12, 1907.

Bristol served as forester of the Bay Shore Lumber Company from June, 1904, until October, 1908. On the latter date he became superintendent of woodlands for the Delaware \& Hudson Company and subsidiary companies, his present position.

$\mathrm{He}$ is a Progressive Republican and a member of the American Forestry Association, the Eastern States Foresters, the Canadian Forestry Association and the American Geological Society. He is a Knights Templar and a Shriner.

\section{Clarence J. Buck}

Business address, 405 Beck Building, Portland, Ore. Residence, 549 East Thirty-ninth Street, Portland, Ore.

Clarence John Buck was born October 16, 1881, in Stockbridge, Mass., the son of John Milton Buck, son of Jeremiah Buck of Stockbridge, and Hattie Elizabeth Buck, daughter of Benjamin Buck of Stockbridge, Mass. They had two other children: Jessie M. and Clifford B. Buck.

$\mathrm{He}$ prepared at the Stockbridge (Mass.) High School and received the degree of B.A. at Williams College in 1903 . 
He was married December 19, 1906, in Pittsfield, Mass., to Miss Edith Fenn, daughter of Charles B. Fenn and Carrie (Stevens) Fenn. They have three children: John Milton Buck, born November II, I907; Gilbert Fenn Buck, born October 30, 1908, and Florence Louise Buck, born June Io, I9II.

Since graduation Buck has identified himself with the Government Service, his first position being forest assistant. $\mathrm{He}$ later served as deputy forest supervisor of the Klamath National Forest, then as forest supervisor of the Crater National Forest. Since 1908 his appointment has been in District 6, first as assistant district forester in operation and now assistant district forester in charge of lands.

$\mathrm{He}$ is a member of the Society of American Fqresters.

\section{Philip T. Harris}

Business address, Forest Service, Tacoma, Wash.

Residence, R. F. D. I, Box 53 P., South Tacoma, Wash.

Philip Talbot Harris was born February Io, I88I, in East Machias, Maine, the son of Austin Harris, who is in the lumber business, and Emily Francis (Pope) Harris. Mr. Harris has always been prominent in public affairs as county treasurer, member of the state legislature and senate, treasurer of Washington Academy and a town selectman. Both sides of the family are of English descent. Three daughters and a second son are all college graduates: Florence Harris, B.A. Boston University '9I; Mabel A. Harris, B.A. Smith '97; Samuel P. Harris, B.A. Bowdoin 'oo (deceased); and Emily Harris, B.S. Northwestern 'o6 and M.A. University of California.

He was prepared at Washington Academy before entering Bowdoin College, where he was graduated with the degree of B.A. in 1903. He was a member of Alpha Delta Phi and elected to Phi Beta Kappa. Before entering the Yale Forest School he had spent two seasons in field work with the Forest Service.

He was married September I4, 1910, in Alameda, Calif., to Miss Dorothea Van Orden, daughter of Leander Van Orden and Kate (Post) Van Orden.

Harris has been continuously in the United States Forest Service since graduation in I905. He served as forest assistant until 1907, forest examiner from 1907 to 1909 , and since the 
latter date in the capacity of deputy supervisor of Rainier Forest, his headquarters at present being Tacoma, Wash.

$\mathrm{He}$ is a member of the Congregational church. He is a member of Masonic orders, Knights of Pythias and the Concatenated Order of Hoo-Hoo.

\title{
Janero Lagdameo
}

\author{
Bureau of Forestry, Manila, P. I.
}

Janero Lagdameo was born in Quinayangan, P. I., in 1880.

He received the degree of B.A. at Ateneo de Manila in 1896 .

After graduation from the Yale Forest School in 1905 Lagdameo entered the Forest Service in the Philippine Islands, where he has since continued. He has furnished no information for this record.

\section{Jacob J. Levison}

Business address, Department of Parks, Brooklyn, N. Y. Residence, 526 Cleveland Street, Brooklyn, N. Y.

Prospect Park, Brooklyn, N. Y.

Jacob Joshua Levison was born January 20, 188I, in Riga, Russia, the son of Julius Levison and Esther (Apte) Levison. The family resides in Russia and the members are chiefly rabbis, teachers and well known philanthropists.

He came to the United States in 1893 , entered the public schools of New York and was graduated in 1896 with two medals. He then studied art at Cooper Union but later gave this up to allow more time for the work at college. He spent eight years in connection with the social work at the University Settlement, where he taught out-door athletics. He received the degree of B.A. at the College of the City of New York in 1902 .

$\mathrm{He}$ is unmarried.

Levison acted as forest assistant for one year and then became a forester in the employ of the City of New York, having charge of the department of Brooklyn and Queens. Since 1908 he has also served as a staff lecturer at the Brooklyn Institute of Arts and Sciences and for the New York City Board of Education, and since 1909 as forester of the American Association for 
Planting and Preservation of City Trees. $\mathrm{He}$ is a member of the executive committee of the Long Island Agricultural Education Association and of the botany department of the Brooklyn Institute of Arts and Sciences; has lectured at the Yale Forest School on ornamental and shade trees, and has been called by many cities to organize tree commissions for them, lecture and start them in their work on the care and planting of trees.

He writes: "My chief interest during the past six years has centered around the city tree problem of the country. Seven years ago I saw the need of championing forestry among the city dwellers and to put the tree problems of our parks on a scientific footing. It was all in the hands of untrained men. Brooklyn and Queens Park departments offered the opportunity for demonstrating the possibilities of such work and from that very moment I had to fight against all sorts of odds to introduce new methods and get scientific tree care recognized. We are still spending nearly $\$ 4,000,000$ annually on parks in New York 'City and only a very small fraction of this goes to tree work. But now we are getting more and more interest in the trees and the people are fast becoming educated to it. It had to be done by systematic and constant effort in writing, lecturing, talking from the platform, defying politicians, etc. I traveled to other cities and did the same there and now we have many cities awake to it. I am now especially interested in seeing municipal forests established in cities and to have these displace the common, conventional and extremely expensive formal park."

Levison is a member of the Ethical Culture Society of Brooklyn, Mason Lodge, Brooklyn Entomological Society, Brooklyn Institute of Arts and Sciences, American Association of Park Superintendents, New York Academy of Sciences, American Forestry Association and the American Tree Planting Association of Brooklyn.

He has written several hundred articles and interviews on city tree work and delivered over three hundred lectures in New York and many other cities throughout the East. His pamphlets have been published by many associations and he has given courses in city tree work in several institutions. 


\section{James P. McDonough}

Business address, Glen Morgan, W. Va. 38 Hallock Street, New Haven, Conn.

James Patrick McDonough was born October 29, 1880, in New Haven, Conn., the son of Frank McDonough, a machinist with the New York, New Haven \& Hartford Railroad Company, and Catherine (Donnelly) McDonough. He has five brothers: Joseph McDonough; Edward Michael McDonough, Yale 'og S.; Vincent McDonough, a graduate of St. Thomas Seminary, Hartford, Conn.; Francis Thomas Aloysius McDonough, Yale '13 S.; and John McDonough, student at St. Thomas Seminary, Hartford, and two sisters: Rosemary and Stella McDonough, both graduates of the New Haven Normal School.

He was prepared at the New Haven High School and in 1903 graduated from Yale College, where he received a second colloquy appointment in his Junior and Senior years.

He was married April 29, 1910, in Beckley, W. Va., to Miss Bess M. Hall of Pulaski, Va., daughter of Leonard and Mabel Hall. They have one son, John McDonough, born March I, I9II, in Glen Morgan, W. Va.

McDonough is employed by the W. M. Ritter Lumber Company of Columbus, Ohio. He entered upon his present position in 1907. Before that he had been engaged in engineering work at Warren, Ark., for the Chicago Lumber \& Coal Company of St. Louis.

He is a member of the Roman Catholic church.

\section{William H. Mast}

Business address, Davenport, Iowa

Home address, Ottumwa, Iowa

William Herbert Mast was born August 16, 1879, in Ottumwa, Wapello County, Iowa, the son of Jacob Gehman Mast, a pioneer and highly respected citizen of Ottumwa (died January 13, I909), and Frances E. (Miller) Mast, the youngest of a family of eight daughters and two sons of Thomas and Jane (Hunter) Miller of Keosauqua, Iowa. Jacob G: Mast was a son of Isaac Mast and a grandson of Bishop Jacob Mast, who emigrated from Switzerland to America in 1750 and settled at Northkill, Berks County, $\mathrm{Pa}$. Wiliam H. Mast has three brothers: Frank Miller Mast, Charles Fulton Mast and Thomas Walter Mast, B.Agr. Iowa State College '97. 
He was born and reared on a farm near Ottumwa, Iowa, attended the country school and in 1893 entered the high school in the small town of Agency in the same county. He was graduated in 1897 and entered Iowa State College, Ames, Iowa, where he received the degree of Bachelor of Agriculture in 1900 .

He was married June 28, 1910, in Ottumwa, Iowa, to Miss Mary Ethelda Morrison, Iowa State College '02, of Seattle, Wash., daughter of John R. Morrison and Mary Coffeen Morrison.

Mast entered the United States Forest Service upon his graduation from Iowa State College in I900. His first position as a forest assistant was in charge of Halsey Nursery in connection with the Nebraska National Forest, and he was supervisor of this forest from 1908 to I9I0. In I9Io he was in the office of planting in Denver; I9IO-I I, in charge of Monument Nursery, Pike National Forest, and in I9I I-I2, forest assistant and acting supervisor of Gunnison National Forest. With W. J. Duppert he has recently taken over the operation of the Davenport (Iowa) Nursery, formerly owned by Nichols \& Lorton.

He writes: "I have developed the systems for nursery and planting work as practiced on the Nebraska and Kansas, and to some extent, on the Pike National Forest. This has included work with methods of seeding, mulching, shading, watering, storing, transplanting, digging, packing and planting. In most cases old systems have been modified or, in a number of cases, new ones instituted. Have devised the Mast Transplanting Tools, which are now being patented, also the Mast Forest Trencher.

"During I909, I9I0 and I9II, I was a special lecturer of the department of forestry, Nebraska University, covering the subjects of 'nursery' and 'planting' work, and in 1912, a special lecturer at the summer school of the Colorado State Normal School.

"Have done extensive work in seed collecting, having gathered coniferous seed in Minnesota, Nebraska, Colorado, New Mexico and Idaho. Have prepared a circular (as yet unpublished) for the Forest Service on the subject of 'Collecting Seed of Rocky Mountain Conifers.' Was the first in the Forest Service to make use of a churn or slatted box shaker to remove seed from cones." 
$\mathrm{He}$ is a Presbyterian, a member of the Society of American Foresters and the Equitable Fraternal Union.

He has published: Forest tree seed collecting, For. and Irr., July, I904; Nursery and planting tools, Am. For., May, 1912; New tools for transplanting conifers, For. Quart., March, 1912.

\section{Clayton D. Mell}

Business address, U. S. Forest Service, Washington, D. C.

Lebanon, $\mathrm{Pa}$.

Clayton Dissinger Mell was born November 25, 1875, in Wernersville, Pa., the son of William Dover Mell and Rebecca (Dissinger) Mell. Both parents are of German descent. He has one brother, William Adam Mell.

He was graduated at Pennsylvania State School at Millersville, $\mathrm{Pa}$., in 1897 with the degree of M.E. He then taught three years and entered the Junior year at Franklin and Marshall College in 1900, where he received the degree of B.A. in I902.

He was married July 3, I911, in Washington, D. C., to Miss Mary Frances Blosser, daughter of Ross and Fannie Blosser.

Mell has served as assistant dendrologist in the United States Forest Service since graduation from the Yale Forest School. He visited England, Germany and Switzerland in 1907 and Cuba in 1911 .

$\mathrm{He}$ is a member of the German Reformed church and the Society of American Foresters.

He has published: (With G. B. Sudworth) Fustic Wood, Circ. 184, U. S. Forest Service; (With G. B. Sudworth) Colombian mahogany, Circ. 185, U. S. Forest Service; (With W. D. Brush) Quebracho wood and its substitutes, Circ. 202, U. S. Forest Service; (With G. B. Sudworth) Distinguishing characteristics of North American gum woods, Bull. 103, U. S. Forest Service; (With G. B. Sudworth) The identification of important North American oak woods, Bull. 102, U. S. Forest Service; (With G. B. Sudworth) A chapter on the western yellow pine wood, Bull. Ior, U. S. Forest Service; Distribution of tannin in tanbark oak, Bull. 75, U. S. Forest Service; Cabinet woods of the future, Am. Lumberman, Oct. 15, I910; Facts about true and spurious mahogany, Hardwood Record, Oct. 26, I910; Basket willow culture, Rep. Printing $\mathrm{C}_{0}$., Lebanon, $\mathrm{Pa}$, I908; Basket willow culture in Germany, Proc. Soc. Am. Foresters, I9Io; A forester whose field is the city, Am. For., Sept., 1910; The forests of St. Mary County, Maryland, Md. Geol. Rep., 
Baltimore, rg07; The histology of resin canals in white fir, Am. For., June, 1910; The basket willow, By William F. Hubbard . . . with a summary by C. D. Mell, Farmer's Bull., 34I; Notes on the identification of a tropical wood, Am. For., Aug., I9Io; Pennsylvania-German plant names, Pa. Ger., XI, No. 9, Sept., I9I0; Pennsylvania-German names of trees, Pa. Ger., XI, No. 12, Dec., I9I0; Practical results in basket willow culture, Circ. 148 , U. S. Forest Service; Production and consumption of basket willows in the United States for 1906 and 1907, Circ. 155, U. S. Forest Service; The use of willow rods by the ancient Germans, $P a$. Ger., XI, No. Io, Oct., I9ro; Classification of woods by structural characters, Am. For., April, 19I0; Consumption of basket willows in the United States for I908, For. Quart., I9II; A confusion of technical terms in the study of wood structure, For. Quart., Dec., I9Ir; History of the investigation of vessels in wood, Proc. Soc. Am. Foresters, VI, No. I, I9II; Fiber lengths of the woods of trees grown under different soil and site conditions, For. Quart., I9ro; Identification of North American walnut woods, Bull. I20, U. S. Forest Service; Circassian walnut and its substitute, Circ. 2IO, U. S. Forest Service.

\section{Walter J. Morrill}

Business address, University of Nebraska, Lincoln, Neb.

Residence, 1848 Prospect Street, Lincoln, Neb.

Walter Jean Morrill was born April 17, 1875, in Madison, Maine, the son of Cyrus David Morrill, assistant surgeon, U. S. Regulars, during a portion of the Civil War, and Clara Maria (Flint) Morrill. Their ancestors came to Massachusetts Bay Colony in 1630 and 1632 and were related to a Mayflower family. They had two other children: Martelle Flint Morrill, Maryland Medical College '04, and Ella Maria Morrill.

He prepared at the high school and Coburn Classical Institute, Waterville, Maine, was graduated at the University of Maine with the degree of B.S. in 1899 and before entering the Yale Forest School taught two years in New Hampshire and two years in South Carolina. He was a member of Kappa Sigma.

He was married September 18, 1907, in Parkersburg, W. Va., to Miss Katharine Cook Stone, daughter of Selden Stone and Victoria (Cook) Stone.

Morrill served as forest assistant on several forests in Colorado from I905 to February, I908; as deputy supervisor of the Pike National Forest, Colorado, from February, I908, to July, I9Io; as supervisor of the Rio Grande National Forest, July, I9Io, to November I5, I9II; and as forest examiner in 
Washington, D. C., until the fall of 1912. He is now professor of forestry at the University of Nebraska, Lincoln, Neb. His previous experience in teaching was as professor of forestry in the Colorado School of Forestry, Colorado Springs, Colo., during 1909-10.

He writes: "My work in the Forest Service in Colorado has made me personally familiar with practically all of the mountainous portions of that state and with most phases of forest service field work there.

"A scholastic year of teaching forestry in the Colorado School of Forestry gave me the opportunity to review the courses I had taken in Yale after some years of practical experience with the result that I am particularly interested in the subject of forest regulation, or management."

$\mathrm{He}$ is a member of the Congregational church. $\mathrm{He}$ is a Progressive Republican, a Blue Lodge Mason and a member of the Society of American Foresters.

He has published: National forests of southwestern Colorado: their resources and conservation, Bull. U. S. Forest Service.

\section{Harry C. Neal}

\section{Dravosburg, $\mathrm{Pa}$.}

Harry Camble Neal was born in Dravosburg, Pa., in 1882.

He was prepared at Pennsylvania State College Preparatory School and received the degree of B.S. at Pennsylvania State College in 1903.

Upon graduation from the Yale Forest School in I905 Neal was appointed a forest assistant in the United States Forest Service. He has furnished no information for this record.

\section{John M. Nelson, Jr.}

Pottsville, $\mathrm{Pa}$.

John Marbury Nelson, Jr., was born March 9, 1883, in Baltimore, Md., the son of John Marbury Nelson, a banker, of Nelson, Cook \& Company, of Baltimore, Md., son of C. K. Nelson and Mary C. (Marbury) Nelson, and Ella Martha (Delaplaine) Nelson, daughter of Edwin and Elizabeth (Charlton) Delaplaine. They had four other children: Edwin D. Nelson, Alexander C. Nelson, William M. Nelson and Mary C. Nelson. 
He was prepared in the Baltimore public schools and Marston's University School. He received the degree of B.A. at Johns Hopkins University in 1903. He was a member of Alpha Delta Phi.

He was married April 10, 1912, in Philadelphia, Pa., to Miss Ellen Cheston McIlvaine, daughter of H. C. McIlvaine and Frances (Randall) McIlvaine.

Nelson was a forest assistant and section chief in the Service from July, 1905, to September, 1909. The following year he was superintendent of the timber department of the Philadelphia and Reading Coal \& Iron Company. From October I5, 1910, to September I, I9II, he held the position of general sales agent for the Carolina Pine Lumber Company, and on the latter date opened a wholesale lumber business in Pottsville, $\mathrm{Pa}$.

His political opinions depend upon the men and party principles. He is a member of the Protestant Episcopal church and of the Society of American Foresters.

\author{
William B. Piper \\ Business address, East Tawas, Mich. \\ Home address, Cambridge, Mass.
}

William Bridge Piper was born November 21, 1880, in Cambridge, Mass., the son of William Taggard Piper, son of Solomon and Mary Elizabeth (Taggard) Piper, whose ancestry dates back to early colonial times, and Anne Palfrey (Bridge) Piper, daughter of William Frederick Bridge and Elizabeth Crosby (Guild) Bridge. They had three other children: Elizabeth Bridge Piper, Anne Taggard Piper (married Matthew Hale), and Ralph Crosby Piper. William T. Piper was prominent in the affairs of Cambridge, Mass, serving on the Common Council, Board of Aldermen, local board of Civil Service Examiners, president of the School Board, on the board of trustees of the Cambridge Public Library, a trustee of the Boston Homeopathic Hospital and the Boston State Hospital, and a director of the Cambridge Trust Company.

He was prepared at the Browne-Nichols' Preparatory School in Cambridge and was graduated with the degree of B.A. at Harvard in 1903.

$\mathrm{He}$ is unmarried.

In the summer of 1905 Piper was located in the Medicine Bow Mountains, Wyo., as forest assistant; the winter, 1905-06, in California. The next summer and until February, 1907, he was furloughed to work with the Delaware \& Hudson Railroad Company in New York State, with headquarters at Lyon 
Mountain. In the spring of 1907 , having been restored to the rolls of the Forest Service, he was located in Clearwater Valley, Mont., until January, 1908, and in and around Bozeman on the Gallatin Forest. In the spring of 1908 he was in charge of a field party in Custer County, Mont., and in the summer of the same year had a field party in West Gallatin Valley near Bozeman.

He spent the early winter, 1908-09, in Washington, D. C., and from February until the middle of April was in charge of a field party in Northern Alabama, working in coöperation with the Tennessee Coal \& Iron Company. The following summer he had a field party in the vicinity of Boulder, Townsend and Bozeman, Mont., and was in Missoula, Mont., the first part of the winter of 1909-IO. In February, 1910, he went to Bozeman to be on the Gallatin Forest. In August, 1910, he was transferred to the Madison Forest with headquarters at Sheridan, Mont., and in March, I9I I, went to Au Sable, Mich., as acting supervisor of the Michigan and Marquette National forests. In the fall of I9II the headquarters of these forests was changed to East Tawas, Mich., on account of the destruction of the towns of Au Sable and Oscoda by fire on July II, I9II.

$\mathrm{He}$ is a member of the Unitarian church.

\section{Merritt B. Pratt \\ Nevada City, Calif.}

Merritt Berry Pratt was born October 3, I878, in Paw Paw, Ill., the son of Wilbur Alfonso Pratt, a druggist, and Mary Evelyn Pratt. His father's people came to Illinois from Deep River, Conn., and his mother's father came from New York to Chicago, where he was a carpenter, later a farmer and wheat grower. $\mathrm{He}$ has one brother and one sister: Helen Harriett Pratt, a member of the class of 1915 at Lake Forest University, and Roger Wilbur Pratt.

He was graduated from the Paw Paw High School in 1897, Morgan Park Academy in 1900 and received the degree of B.S. at the University of Chicago in 1903. He was a member of Delta Upsilon.

He was married November 24, 1907, in Nevada City, Calif., to Miss Laura May Schroder, daughter of Charles Schroder and Ida Schroder. They have a daughter, Mary Louise Pratt, born June II, I9II, in Nevada City, Calif. 
Pratt served as forest assistant until 1909, when he was appointed deputy forest supervisor of Tahoe National Forest, with headquarters at Nevada City, Calif.

$\mathrm{He}$ is a member of the Methodist church.

He has published: California red fir in the Tahoe National Forest, For. Quart., Ithaca, N. Y., June, 1907; Results of "light burning" near Nevada City, Calif., For. Quart., Cambridge, Mass., Sept., I9II ; Comparison of large and small sawmills on Tahoe National Forest, For. Quart.; Fire working-plan on Tahoe National Forest, Am. For., Washington, D. C., June, I9I2.

\section{Jeremiah Rebmann}

III Marion Street, Columbia, S. C.

Jeremiah Rebmann was born in I869 in Würtemberg, Germany.

He was prepared at public schools in Germany and the University of Nebraska preparatory school. He received the degree of B.S. at the University of Nebraska in 1898 .

Rebmann was graduated at the Yale Forest School in 1905 and then entered the Government Service as an assistant. He has furnished no information for this record.

\section{Samuel J. Record}

Business address, 360 Prospect Street, New Haven, Conn. Residence, 187 Mansfield Street, New Haven, Conn.

Samuel James Record was born March Io, I88I, in Crawfordsville, Ind., the son of James Knox Polk Records (died in I88I) and Mary Minerva (Hutton) Records. His father was for several years a school teacher, but his principal occupation was farming. On his father's side he is the grandson of William Tully Records and Susan Records and a descendant of John Records and Ann (Calloway) Records of England, who settled in Sussex County, Delaware, sometime before 1750 . $\mathrm{He}$ is the grandson on his mother's side of Samuel M. Hutton (died March 12, 1905) and Miriam (Harland) Hutton. Samuel Hutton was born near Lexington, Rockbridge County, Va., and removed to Indiana in r836, where he was engaged in farming and in operating a sawmill. He has one brother, William F. Record.

He prepared at the Crawfordsville (Ind.) High School and received the degrees of B.A. and M.A. from Wabash College in 1903 and 1906. He was a member of Phi Gamma Delta. 
He was married April I, 1906, in Crawfordsville, Ind., to Miss Mary Elizabeth Strauss of Topeka, Kans., daughter of Charles Edward Strauss and Sarah (Schooley) Strauss. They have had four children: Harold Clayton Record, born January 5, 1907, and died January 12, 1907; twins, Mason Thomas Record and Mary Elizabeth Record, born March 31, I909, and Alice Louise Record, born May 25, I9II.

From July I, 1904, to April 30, 1907, Record served as assistant in the United States Forest Service. On May I, 1907, he was made chief of the Section of Reconnaissance (M) and on November 25 of the same year became supervisor. He was again appointed forest assistant July 20, I9I0, which position he held until March 31, I9I I.

From January I to June 30, I906, he acted as instructor in botany and forestry at Wabash College and from July I, I9Io, to June 30, I9I I, was instructor in forestry at the Yale Forest School. He received his present appointment of assistant professor of forest products at Yale on July I, I9II.

In politics Record is a Progressive Republican. He was elected to the Yale chapter of Sigma Xi in 1912 and has been a member of the board of editors of the Forestry Quarterly and managing editor of the Yale Forest School News. He is a member of the American Association for the Advancement of Science and of the American and Connecticut Forestry associations, and is a Mason. He is Secretary of the Class of 1905, Yale Forest School.

He has published: Forest conditions in Montgomery County, Indiana, Proc. Ind. Acad. Sci., 1902, pp. 84-93; Forestry in Indiana, For. and Irr., March, 1905, pp. 107-112; Forestry-A profession for young men, $P u b .$, Wabash College, 1906, pp. 8; The hardy catalpa, Pub. 22, Department of Botany, Wabash College, I906, pp. 15; The Middle West: Notes on the attitudes which several states hold toward their timber supplies, For. and Irr., April, 1907, pp. 177-180; Forest fire insurance in Germany, Proc. Soc. Am. Foresters, II, No. 3, pp. 95-102, July, 1907; The forests of Arkansas, For. Quart., V, No. 37, pp. 296-301, Sept., 1907; Suggestions to woodlot owners in the Ohio Valley region, Circ. 138, For. Ser., Feb., 1908, pp. 15; Missouri's opportunities in forestry, Ann. Rep., Mo. State Bd. Hort., 1908, pp. 7; The forest resources of Arkansas, Little Rock, Ark., r910, pp. 35; Forest conditions of the Ozark Region of Missouri, Bull. 89, Mo. St. Agric. Exp. Sta., Univ. of Mo., Nov., I910, pp. 195-280; Some new ideas in controlling forest fires, Am. For., April, 1911, pp. 197-203; Grain and texture in wood, For. Quart., IX, No. r, 
pp. 22-25, I9II; Pith flecks or medullary spots in wood, For. Quart., IX, No. 2, pp. 244-252, I9II; Tier-like arrangement of the elements of certain woods, Science, Jan. 12, 1912, pp. 75-77; Identification of the economic woods of the United States, N. Y., John Wiley \& Sons, I9r2, 8 vo, vii +117 pp., I5 fig.; numerous articles in trade journals.

\section{Arthur C. Ringland}

Business address, U. S. Forest Service, Albuquerque, N. Mex. Home address, 56 Church Street, Montclair, N. J. U. S. Forest Service, Washington, D. C.

Arthur Cuming Ringland was born September 29, I882, in Brooklyn, N. Y., the son of Robert B. Ringland, who is of Irish and Scotch descent, and Mary (Glenister) Ringland, who is of English descent. He has one brother, Robert Finley Ringland, M.D. Columbia 'o3.

He was prepared at the Montclair High School, Montclair, N. J., and before entering the Forest School took some special courses in Sheff.

$\mathrm{He}$ is unmarried.

Ringland acted as forest assistant from 1905 to 1907 , then one year as assistant forester, and since 1908 has been district forester, in charge of District 3 , with headquarters at Albuquerque, N. Mex.

$\mathrm{He}$ is a member of the Protestant Episcopal church. He is a National Progressive in politics, and is a member of the Society of American Foresters and the Century Club of Washington, D. C.

\section{William F. Sherfesee \\ Business address, Bureau of Forestry, Manila, $P . I$. Home address, Charleston, S. C.}

William Forsythe Sherfesee was born May 23, I882, near Brevard, N. C., the son of Louis Sherfesee and Annie (Griffith) Sherfesee. He has three brothers and two sisters: Moseley F., Elizabeth, Annie Louise, Louis and Robert Augustus Sherfesee, B.A. Davidson College.

He prepared at the Charleston High School, Charleston, S. C., and received the degree of B.A. at the College of Charleston, S. C., in 1903.

$\mathrm{He}$ is unmarried.

The various positions held by Sherfesee with the Forest Service are forest assistant, assistant chief and chief in the office of wood preservation, forester of the Philippine Bureau of 
Forestry and on July 1, 1912, appointed assistant director of the Philippine Bureau of Forestry.

$\mathrm{He}$ is a member of the Society of American Foresters, Century Club of Washington, D. C., Army and Navy Club of Manila and the Baguio Country Club, Baguio, P. I.

He has written various articles for publications of the United States Forest Service.

\section{Ferdinand A. Silcox}

Business address, Forest Service, Missoula, Mont. Residence, 529 Cleveland Street, Missoula, Mont.

Ferdinand Augustus Silcox was born December 25, 1882, in Columbus, Ga., the son of Ferdinand Augustus Silcox, president of the Charleston Cotton Mills, and Carrie Olivia (Spear) Silcox. His father was of English descent and his mother of Dutch and French origin.

He was prepared at the Charleston High School and received the degree of B.S. at the College of Charleston, S. C., in 1903 with honors in chemistry and sociology. He was a member of Phi Kappa Sigma.

He was married March 4, 1908, in Charleston, S. C., to Miss Marie Louise Thatcher of Charleston, S. C.

Silcox is a district forester, in charge of District $I$, with headquarters at Missoula, Mont. He writes: "During summer of 1904 I worked in West Virginia making a working plan under Ralph Hawley for the U. S. Coal \& Coke Company, approximately 60,000 acres. Passed civil service exams in 1905 and was assigned to the Leadville Forest in Colorado. For three months I worked as ranger, forest assistant and somewhat in the capacity of supervisor. The organization at that time had not crystallized and one man had charge of the Pike, Leadville and Holy Cross forests from Denver. In September, 1905, I was placed in charge of the Holy Cross Forest as acting supervisor to establish the administration and get things going. This forest was the center of bitter opposition to the Service and it was here that the famous Fred Light case first came up. After getting things under way I was sent to the San Juan and Montezuma with headquarters at Durango to get the administration under way. These forests included together about $3,000,000$ acres, and when I arrived in early January, I906, 
nothing had been done. I stayed until April and was then sent to Montana with Mr. E. A. Sherman. I stayed two weeks and was called to Washington to serve in the capacity of district forester for District $\mathrm{I}$. This under the old scheme was in no way similar to the present position. It was an assignment to handle general omnibus letters for signature of Washington office administration officers. Left Washington as assistant forest inspector and went to New Mexico to look over the Portales with the result of eliminating the entire forest. Came back to Montana in the spring of 1907 as forest inspector and put the administration on the newly created cabinet. With Redington, Class of 1904, worked up the plan of re-districting the forests in Montana and Idaho. From 1907 to December I, I908, was a general inspection officer. With the creation of the district office at Missoula for District I, I was appointed assistant district forester, which title was changed later to associate district forester upon district forester W. B. Greeley being called into Washington as assistant forester. I was made district forester July I, I9I I, which position I now hold."

$\mathrm{He}$ is a member of the Society of American Foresters.

\section{Gordon E. Tower}

Business address, Waldo Hills Orchard Company, Route 5, Salem, Ore. Home address, Belding, Mich.

Gordon Edwin Tower was born July 5, 1877 , in Belding, Mich., the son of Benjamin Franklin Tower, a Civil War veteran, and Eva L. (Peterson) Tower. His grandfather was a Vermont Yankee. He has two brothers and a sister: R. Tower, B.S. Michigan Agricultural College, Glen Tower, Belding High School, and Nellie E. Tower.

He prepared at the Belding (Mich.) High School, was graduated with the degree of B.S. at Michigan Agricultural College in rgor and had served in the Forest Service from July, Igor, until entering the Yale Forest School.

He was married December 21, 1905, in Portland, Maine, to Miss Bessie Geraldine Leeds, of Sioux City, Iowa, daughter of William B. Leeds and Sarah Ann Leeds. They have two children: William Gordon Tower, born December 26, 1906, in Orono, Maine, and Ellen Tower, born May 22, 1909, in Orono, Maine.

Tower was an assistant at the Yale Forest School at Milford, $\mathrm{Pa}$, during the summer of 1905 and then became professor of 
forestry at the University of Maine, where he remained until 19I0. In July of the latter year he became a horticulturist for the Waldo Hills Orchard Company, in Salem, Ore.

$\mathrm{He}$ is a Progressive Republican, a member of the Oregon Horticultural Society and the Free and Accepted Masons.

He has published: Estimation of cellulose in wood by the chlorination method; Study of reproductive characteristics of lodgepole pine, Proc. Soc. Am. Foresters, 1907 to 1908.

\section{Lage Wernstedt}

\section{Forest Service, Portland, Ore.}

Lage Wernstedt was born May 3, 1878, in Strengnäs, Sweden, the son of Judge Lage Wernstedt and Hanna (Ringborg) Wernstedt. $\mathrm{He}$ has seven brothers, most of whom are officers in the Swedish army and navy.

He was prepared at the Gymnasium, Norrköping, Sweden, and received the degree of M.E. at the Royal Institute of Technology, Stockholm, in 1902, and before entering the Yale Forest School, spent one year as a draftsman.

$\mathrm{He}$ is unmarried.

Since graduation Wernstedt has been engaged as a forest expert and assistant. He writes: "I have been chiefly engaged in boundary work and general reconnaissance in Arizona, California, Oregon, Nevada, Washington, Idaho and Alaska. Also in national forest routine on the Priest River, Chugach and Columbia National forests. I have lately been occupied in making topographic maps and surveys."

$\mathrm{He}$ is a member of the Society of American Foresters.

\section{Trueman D. Woodbury}

Business address, 1204 First National Bank Building, San Francisco, Calif. Residence, 840 Van Ness Avenue, San Francisco, Calif.

Care Forest Service, San Francisco, Calif.

Trueman Doane Woodbury was born September 11, 1879, in Bluehill, Maine, the son of Samuel Woodbury, a Baptist minister, son of Samuel and Jane Woodbury, and Adelia (Doane) Woodbury, daughter of Trueman and Thankful Doane. Both parents were descended from English ancestors, who settled early in this country, in the vicinity of Salem and Cape Cod, Mass. 
He prepared at Saxtons River Academy, Vermont, and received the degree of $\mathrm{Ph} . \mathrm{B}$. from Brown University in 1903. He was a member of Phi Beta Kappa.

$\mathrm{He}$ is unmarried.

Woodbury entered the Forest Service on graduation in 1905 and was forest assistant two years, inspector for two years and has since been an assistant district forester, with headquarters at San Francisco, Calif.

$\mathrm{He}$ is a Republican. $\mathrm{He}$ is a member of the Commonwealth Club of San Francisco and is an Odd Fellow.

\section{Karl W. Woodward}

Forest Service, Washington, D. C.

Karl Wilson Woodward was born July 24, 1881, in Detroit, Mich., the son of Robert Simpson Woodward, C.E. University of Michigan '72, Ph.D. '92, president of the Carnegie Institute, Washington, and Martha Gretton (Bond) Woodward. Both parents are of English-Dutch descent, the families having been in this country several generations. He has two brothers, Robert Simpson Woodward, Jr., C.E. Columbia 'or, and William L. Woodward, M.E. Massachusetts Institute of Technology 'o7.

He prepared at Montclair High School, Montclair, N. J., and received the degree of B.A. at Cornell in I904.

He was married September II, I909, in Missoula, Mont., to Miss Olive L. Smith, daughter of Edward and L. Smith.

Woodward is in charge of examination of lands and the acquisition of lands under the Weeks Law. His previous positions were forest assistant, assistant forest inspector, in charge of the project of "Northern Pacific Estimates" and as adviser to the Dominican government.

He has written articles for the Forestry Quarterly and the Bulletins of the Bureau of American Republics.

\section{Theodore C. Zschokke}

Business address, 236 Broad Street, San Francisco, Calif.

Residence, Palo Alto, Calif.

Theodore Christian Zschokke was born October 9, 1875, in Wapello, Iowa, the son of Oscar Zschokke, deceased, son of Theodore and Julia 
(Koecklin) Zschokke, and grandson of Heinrich Zschokke, a Swiss writer, and Anna Margaret (Probst) Zschokke, who was born in Bavaria and came to the United States at the age of four. They had two other children: Arthur Jacob Zschokke, B.A. Leland Stanford, Jr., '02, and Irma Julia Zschokke, B.A. Leland Stanford, Jr., '08.

He prepared at the Palo Alto High School, Palo Alto, Calif., and was graduated from Leland Stanford, Jr., University in 1903 with the degree of B.A. He had enlisted in Company K, First California Infantry, U. S. V., June 14, 1898, being discharged June 30, 1899. He enlisted in Company L, Thirty-sixth Infantry, U. S. V., July I, I 899 , being discharged January 25, 190I. He took part in engagements and campaigns of these regiments in the Philippines.

He was married September 15, 1904, in Mountain View, Calif., to Miss Mabel Grace Lyman, daughter of Edmund Lyman and May (Alney) Lyman. They have had two children: Theodore Oscar Zschokke, born September 22, 1906, in Manila, P. I., and Charles Edmund Zschokke, born July 7, 1912, and died July 8, 1912.

Zschokke served as forester of the Bureau of Forestry, Manila, P. I., from September I, 1905, to September 14, I910. On March 14, 1912, he became a partner in certain of the contracts of the Pacific Grading Company of San Francisco, and acts as foreman in charge of operations.

$\mathrm{He}$ is a Progressive Republican and a Mason.

\section{Graduates holding Certificate but not Degree}

\section{Harry M. Hale}

Okanogan, Wash.

Harry Munro Hale was born March 23, 188I, in Elbridge, N. Y., the son of W. S. Hale and Czarina (Munro) Hale.

He was prepared at the Munro Collegiate Institute, Elbridge, N. Y., and studied two years in the Cornell Forestry School before entering Yale.

He was married November 4, I9I0, in Aberdeen, Wash., to Miss Helen Greenwood, of Syracuse, N. Y.

Since leaving the Yale Forest School Hale has been in the Government Service, as forest expert, assistant, deputy supervisor and is at present supervisor of the Okanogan Forest, District 6, with headquarters at Okanogan, Wash.

$\mathrm{He}$ is a member of the Congregational church. 


\section{John S. Holmes}

Chapel Hill, N. C.

John Simcox Holmes was born May 3I, I868, in Coburg, Ontario, Canada, the son of George Holmes, who was born at Kings Heath, Birmingham, England, and Georgena Beatrice (Simcox) Holmes, who was born at Camp Hill, Birmingham, England. He has five brothers and sisters: George Hamilton, Lawrence Edward, Alan Launcelot, Mary Elise Beatrice (Allston) and Evelyn Holmes.

He was prepared at the public schools of North Wales and in a private school in North Carolina. He attended the University of North Carolina, taking a two-year course in agriculture, leaving in 1888 . He farmed in Henderson County, N. C., from then until November, I902, when he entered the U. S. Forest Service as student assistant.

He was married November I, 1909, in Georgetown, D. C., to Miss Emilie Rose Smedes, of Washington, D. C., daughter of John Esten Cooke Smedes and Henrietta Rea (Watts) Smedes.

During 1905 Holmes was engaged in commercial tree studies in the South Appalachians and then was transferred to timber sale inspection in District 3 in I906. He began the study of forest conditions of Kentucky in the summer of 1907 and received his present appointment as forester for the North Carolina Geological and Economic Survey in June, I909. He spent the spring of 1912 in a trip through representative forests of France, Switzerland, Germany and some watersheds of England.

$\mathrm{He}$ is Independent in politics but holds progressive views. $\mathrm{He}$ is a member of the Protestant Episcopal church, the Society of American Foresters, American Forestry Association, Canadian Forestry Association, North Carolina and Georgia Forestry associations.

He has published: Brush disposal, Circ. U. S. Forest Service; Forest conditions in western North Carolina, Bull. 23, N. C. Geol. and Econ. Sur., Economic Papers, 19, 22, 25, etc.

\section{Stanton G. Smith}

Business address, Forest Service, Seattle, Wash.

Home address, Berkley, Harford County, Md.

Stanton Gould Smith was born July I9, I882, in Berkley, Md., the son of Bernard Gilpin Smith and Rebekah Wright (Gould) Smith. A sister, Dorothy Cowgill Smith, was graduated at Smith College in 1909. 
He prepared at Westtown Boarding School, Westtown, $\mathrm{Pa}$., and attended Cornell University for a time before entering Yale.

$\mathrm{He}$ is unmarried.

Smith entered the Forest Service in 1906 and has served in the positions of forest assistant, chief of section of boundaries, forest examiner and forest supervisor. He was appointed to this last position in October, 1909, and was located in Albuquerque, N. Mex., District 3, until January, 1913, when he was transferred to District 6, as supervisor of Snoqualmie National Forest, being stationed in Seattle, Wash. The district headquarters are in Portland, Ore.

\section{Non Graduates}

\section{James M. Fetherolf}

Business address, Forest Service, Ogden, Utah

Residence, 2550 Monroe Avenue, Ogden, Utah

James Milton Fetherolf was born September 27, 1874, in Kempton, Pa., the son of James K. Fetherolf and Lydia D. (Kistler) Fetherolf. Both parents are of Pennsylvania German or Palatinate descent. They had six other children, three sons and three daughters: D. E. Fetherolf, Muhlenberg College, Lutheran Theological Seminary; William Plilip Fetherolf, Muhlenberg College, M.A. Princeton '04; N. J. Fetherolf, a graduate of Keystone State Normal School, forest planting assistant at Wasatch Nursery; Anna L. L. Fetherolf, Keystone State Normal School; Emma K. Fetherolf and Ella M. Fetherolf.

He attended the common schools, worked on the farm, taught for a number of years, prepared for college at Lynnville Academy, and was graduated at Muhlenberg College with the degree of B.A. in I90I. Before entering the Yale Forest School he had worked for the Bureau of Forestry as a student assistant.

He was married February 27, 1908, in Washington, D. C., to Miss Grace Moser, daughter of James Henry and Martha Scoville Moser. They have one son: James Moser Fetherolf, born May 13, 1910, in Ogden, Utah.

Fetherolf served as forest assistant from 1904 to 1906 , forest inspector, 1906 to 1908 , and forest examiner, 1908 to 1912 . He is now in charge of the reforestation work in District 4.

He writes: "During the summer of 1904, I made an extensive study of planted groves in the two Dakotas and Western Minne- 
sota. In this study extensive growth and volume measurements were made in typical groves of various planted species with the idea of finding out the relative value of each species for further planting.

"During the summer of I906 a thorough planting reconnaissance was made of the Wasatch Forest in Utah with a view toward extensive reforestation of the denuded watersheds from which the city of Salt Lake derives its water supply, and in the spring of 1907 the Wasatch Nursery was established for the purpose of growing the needed planting stock. Since then this and other large nurseries in the district have become centers for distribution to other forests.

During the summer of 1908 I was a general inspector in District 4 with headquarters at Salt Lake. Since then I have been in charge of the reforestation work in District 4 with headquarters at Ogden, Utah.

He was brought up in the Lutheran Evangelical church of the General Council. He is a member of the Society of American Foresters, American Forestry Association, National Geographic Society and the Utah Pharmaceutical Association (honorary).

He has published: Forest planting on the northern prairies, Circ. 145, U. S. Forest Service, March 20, 1908; Forest planting in national forests1. Reforestation in the intermountain region, For. Quart., VII, No. 2, June, 1909; Ferns of Texas; Forests of Texas; Forestry investigations in the Dakotas; Forest extension in the Dakotas.

\section{David G. Kinney}

United States Forest Service, San Diego, Calif. Home address, Care A. E. Muth, 524 Hale Avenue, Avondale, Cincinnati, Ohio

David Golden Kinney was born March 4, 1879, in Utica, N. Y., the son of Thomas Edward Kinney, LL.B. University of Virginia Law School, a lawyer (died in November, I90r), and Fanny (Golden) Kinney, daughter of David Golden, of Utica, N. Y. He is of Irish ancestry on his father's side and of Holland Dutch on his mother's. He has two brothers and a sister: Edward Kinney, studied at Harvard from 1904 to 1907 , Thomas Edward Kinney, Williams $e x$-'o9, and Rose Kinney, New York Art School.

He was prepared at the Utica Free Academy and at St. Paul's School, Concord, N. H., graduating in 1898 . The following year he entered 
Harvard, leaving in 1901. In July, 1901, he began forestry work with the government and passed the civil service examinations in 1904.

He was married May II, 1906, in Cincinnati, Ohio, to Miss Lucy Muth, daughter of August and Emma (Helleberg) Muth. They have one daughter: Virginia Kinney, born November 28, 1909, in Missoula, Mont.

After leaving the Yale Forest School Kinney served a year in the forest products division of the Forest Service. From July I, 1905, to March 14, 1907, he was technical assistant on the forests now embraced by the Flathead, Missoula and Glacier National Park. From March 15, 1907, to 1912, he was a forest supervisor at Kootenai, Cabinet $(\mathrm{N})$ and Missoula National forests. In the fall of 1912 he was on furlough from duty and living in Cincinnati, Ohio. He was appointed supervisor of Cleveland National Forest, San Diego, Calif., on March I, I9r3.

$\mathrm{He}$ is a Progressive Republican. $\mathrm{He}$ is a member of the Episcopal church, the National Geographic Society and the Society of American Foresters.

\section{Harold D. Langille}

Business address, 104 Spalding Building, Portland, Ore. Residence, 683 Wasco Street, Portland, Ore.

Harold Douglas Langille was born September 19, 1874, in Tusket, Nova Scotia, the son of James Leander Langille and Sarah (Harding) Langille. He has two brothers: William A. Langille and Herbert B. Langille.

He moved to Oregon in 1883 , where he received his education in a country school. He grew up with a special interest for trees and botany and in I900 was engaged by the United States Geological Survey, later being transferred to the Bureau of Forestry, then to the interior department as forest inspector on forest reserves.

$\mathrm{He}$ is unmarried.

Langille studied in the Yale Forest School one year and served as forest inspector until August, 1905. He then resigned from government service and engaged in the real estate and timber business until December, 1906, when he became western manager of the Portland office of James D. Lacey \& Company, timber land factors. 
$\mathrm{He}$ has devoted most of his time to the examination of the forests of the Pacific Coast and made one trip exploring the forests of Chile. He is secretary of the Oregon Conservation Association.

$\mathrm{He}$ served three years in the Oregon National Guard and is Progressive in politics. $\mathrm{He}$ is a member of the Portland Commercial Club and the Irvington Club.

He has published: Forest conditions in the Cascade Forest Reserve, Prof. Paper No. 9, U. S. Gov. Ser., 1903; Taxation of timber, Ore. Forester, Portland, Ore., March, 1908; Forest chapter in "The guardians of the Columbia" by John $\mathrm{H}$. Williams, Tacoma, Wash., 1912 .

\section{Chester A. Mathewson}

Business address, Training School for Teachers, Brooklyn, N. Y. Residence, 354 New York Avenue, Brooklyn, N. Y.

Chester Arthur Mathewson was born December II, 1878, in Cincinnati, Ohio, the son of Lewis W. Mathewson, a civil engineer, and Mary (Cannon) Mathewson. They were of New England ancestry. He has two brothers, Walter B. Mathewson and Stanley Mathewson, M.E. University of Cincinnati.

$\mathrm{He}$ attended the University of Cincinnati before entering Yale and taught in secondary schools.

He was married August 28, 1907, in Bond Hill, Ohio, to Miss Nan Jenny, daughter of William M. Jenny and Mary (Manning) Jenny. They have one daughter: Marian Estelle Mathewson, born May 9, 1908, in New York City.

Mathewson received the degree of B.S. at Columbia University in 1905, M.A. in 1906 and Ph.D. in 1912. He has taught biology during this period, holding the following positions: instructor, Columbia University, 1905-06; Plainfield, N. J., I906-07; High School of Commerce, New York City, 1907-10; and professor of biology at the Training School for Teachers, Brooklyn, N. Y., since I9IO.

He was elected to membership in Sigma Xi in March, I9I2, and is also a member of the Biochemical Association of Columbia University. 
He has published: Course of pollen tube in Houstonia, Bull. Torr. Bot. Club, N. Y. City, 1906; Practical and scientific biology, Nature Study Rev., 1909; Practical biology, Yr. Book, N. E. A., 1910; A study of common biochemical tests, 1912.

\section{Ernest A. Sanders}

Westerville, Ohio

Ernest Avery Sanders received the degree of M.A. at Ohio State University in 1903. He was registered at the Forest School during a part of the Junior year. He has furnished no information for this record.

\section{Herbert O. Stabler}

Business address, Forest Service, 501 Beck Building, Portland, Ore.

Herbert Osburn Stabler was born December 25, 1878, in Sandy Spring, Md., the son of Asa M. Stabler, president of the Sandy Spring Savings Institution, and Albina (Osburn) Stabler. Both parents are of English descent, his mother's ancestors having first settled in this country in Virginia. He has three brothers: Newton, Mortimer and Llewellyn Stabler.

He was prepared at the George School in Pennsylvania and attended Cornell Forestry School for the year previous to its discontinuance.

He was married April 28, 1908, in Albany. N. Y., to Miss Elizabeth Elbrey of Sandy Spring, Md., daughter of Major Frederick W. Elbrey, a surgeon, U. S. Army, retired, and Katherine Cleggett Elbrey.

Stabler was engaged as forest assistant on boundary work from 1905 to 1907 ; assistant chief of boundaries, July 29 to November 30, I907; chief of boundaries, December I, I907, to April 30, I908; assistant chief, office of lands, May I, I908, to October 31, 1908. Since November I, I908, he has been forest supervisor of Columbia National Forest, Washington, with headquarters in Portland.

He writes: "Since 1902 I have seen the Forest Service grow from little to big things, which has been fine. The Columbia Forest is a well-timbered, undeveloped country-all in all the best forest in the States-with the best headquarters."

$\mathrm{He}$ is a member of the Society of Friends. He is a member of the Concatenated Order of Hoo-Hoo. 


\section{Gardiner Watkins}

317 Broadway, New York City

Gardiner Watkins was graduated with the degree of B.A. at Princeton University in 1903 . He was registered at the Yale Forest School during the Junior year. $\mathrm{He}$ has furnished no information for this record.

\section{Arnot W. Whetstone}

Van Buren, Ohio

Arnot Wilson Whetstone received the degree of M.A. at Ohio State University in 1903. He was registered at the Forest School during a part of the Junior year. He has furnished no information for this record.

\section{Edmund J. Zavitz \\ Ontario Agricultural College, Guelph, Ontario, Canada}

Edmund John Zavitz was born July 9, 1875, in Ridgeway, Ontario, the son of Joseph I. Zavitz, a merchant, and Dorothy (Prout) Zavitz. His father was a Canadian born of German Swiss origin, his father coming to Canada at the time of the American Revolution. His mother was born in Cornwall, England, of Celtic origin.

He attended Woodstock College and received the degree of B.A. from McMaster University, Toronto, in 1903.

He was married December 28, I905, in Toronto, Canada, to Miss Jessie E. Dryden, of Brooklin, Ontario, daughter of John and Mary Dryden. They have three children: John Dryden Zavitz, born December 1, 1906, in Guelph, Ontario; Edmund Ross Zavitz, born March 14, 1909, in Guelph, Ontario, and Deane Clarance Zavitz, born May 21, 1912, in Guelph, Ontario.

Since leaving the Forest School Zavitz has been employed as a forester at the Ontario Agricultural College and in the Department of Agriculture of Ontario.

$\mathrm{He}$ is a Baptist. He is a member of the Canadian Club and of the Society of Canadian Forest Engineers.

He has published: Farm Forestry Bull., I55, Ontario Dept. Agric., 1907; Reforestation of waste lands in southern Ontario, Ontario Dept. Agric., 1908; annual reports in Ontario Agric. Coll. Rep., 1905-12. 


\section{CLASS OF 1906}

\section{Graduates holding Degree of M.F.}

\section{J. Howard Allison}

Business address, Care of College of Forestry, University Farm, St. Paul, Minn.

Residence, 2116 Carter Avenue, St. Paul, Minn.

Granby, Conn.

John Howard Allison was born September 25, 1883, in Enst Granby, Conn., the son of John Alexander Allison, a farmer and holder of various town offices, and Mary Elizabeth (Mack) Allison. On his father's side .he is Scotch, and on his mother's Irish. He has one brother, Nathan K. Allison, who attended Trinity College in Hartford in I9Ir.

He was prepared at the district schools in East Granby and Granby and at the Hartford High School in Hartford, Conn., and graduated from the Sheffield Scientific School at Yale in 1905.

He was married September 6, 1911, in New Haven, Conn., to Miss Mabel Ann Shepard of Hamden, Conn., daughter of Henry Shepard and Alice M. (Warner) Shepard. They have a son, John Howard Allison, Jr., born April I9, I913.

From July I6, I906, until January I, I909, Allison held the position of forest assistant, assigned to general administration work on the Coconino (old San Francisco Mountains) National Forest until April I, 1908, and from July I, I908, until January I, I909, he was in charge of the Coconino National Forest reconnaissance party. From then until August I5, I9II, he was inspecting reconnaissance work or in charge of field parties in District 3. He says: "During this time I prepared the Coconino Working Plan (area now embraced in the CoconinoTusayan), which I believe I could now greatly improve. I do not now believe the Service is following the right 'tack' to get a working plan which produces 'plans' of value to supervisors. Since February I, I912, I have been in charge of reconnaissance and since June I5, I912, also in charge of the office of 'Geography' in District 3. During this time I have gathered the data for an accurate topographic and type map of the Sitgreaves, which I believe the Service will publish as a 
three color map late this fall. I have other forest maps in the process of compilation." He resigned from the Service in January, I9I3, to take up teaching at the College of Forestry at St. Paul, Minn.

Concerning his travels, Allison writes: "My travels, outside of trips in connection with my duties in the Service, have been confined to brief pleasure trips to California (1906, I909 and I9II), the Yellowstone National Park (1909) and through the Canadian Rockies along the Canadian Pacific Railroad (I9II)."

He is a Congregationalist, and in politics is a Progressive Republican. From July, I907, to July, I9I0, he was a private in the Arizona National Guard.

\section{Fred E. Ames}

Business address, United States Forest Service, Beck Building, Portland, Ore.

Residence, University Club, Portland, Ore.

Fred Elijah Ames was born July 21, 1880, in Spencer, Mass., the son of James Howe Ames, member of the Massachusetts legislature and a merchant in Spencer for twenty-five years, and Maria Theresa (Hill) Ames. $\mathrm{He}$ is of English ancestry. He has one brother, Leroy Allston Ames, B.A. Harvard ' 96 and M.A. 'or, and two sisters: Alice Louise Ames and Florence Ella Ames.

He was prepared at the David Prouty High School, Spencer, Mass., and attended the Lawrence Scientific School, Harvard, in 1899-00. In 1903 he received the degree of B.A. at Harvard, where he was a member of Delta Upsilon. During the year 1903-04 he was employed in a banking house in Boston, Mass.

$\mathrm{He}$ is unmarried.

Ames is assistant district forester in the United States Forest Service, in charge of the office of silviculture, District 6, Portland, Ore. Upon entering the Service in July, 1906, he became forest assistant with headquarters at Washington, D. C. This position he held until April, 1907, when he was appointed assistant inspector with headquarters at Portland, Ore. In July, 1907, he was made inspector and on December I, 1908, chief of silviculture, which position he held until his present appointment, January I, I9IO. 
He writes: "After being graduated from the Forest School, received appointment to the United States Forest Service and was assigned to the Santa Catalina National Forest, Arizona, to report on the advisability of a large timber sale. From August to December, 1908, estimated and mapped timber on that forest. Then recalled to Washington for three months for office assignment. In April, 1907, was assigned as assistant inspector to the northwest district under Inspector E. T. Allen. Until August, 1908, was engaged in general inspection of forests in Oregon and Washington. In August called to Washington for office assignment preparatory to new work when reorganization of Forest Service was put into effect. December, 1908, returned to Portland as chief of silviculture in District 6, comprising Oregon, Washington and Alaska, in charge of timber sales, planting, silvics and reconnaissance. Have held this position since then with change in title to assistant district forester. Work has consisted of office and forest supervision of above lines of work on the forests of the district."

$\mathrm{He}$ is a member of the Congregational church and in politics is an Independent. He was elected to Sigma $\mathrm{Xi}$ while at Yale and is also a member of the Society of American Foresters, the National Geographic Society, the Multuomah Athletic Club of Portland, Ore., and the University Club of Portland.

\section{Martin L. Erickson}

Business address, Medford, Ore.

Home address, Flandreau, S. Dak.

Martin Lewis Erickson was born June 14, 1880, in Saint Olaf, Iowa, the son of O. W. Erickson and Gunild (Thompson) Erickson. $\mathrm{He}$ is of Norwegian ancestry. He has two brothers: Theodore O. Erickson, B.A. University of Minnesota 'OI and LL.B. 'O3, and Eric E. Erickson.

He was prepared at the high school in Flandreau, S. Dak., and in Ig0I attended the South Dakota State Agricultural College. In 1903 he graduated from the Agricultural Department of the University of Minnesota. While in college he worked for lumber companies during vacations.

He is unmarried.

Erickson is supervisor of the Crater National Forest, with headquarters in Medford, Ore. He has held this position since December I, 1908. 


\section{Dennis C. A. Galarneau}

Business address, Department of Natural Resources, Canadian Pacific Railway, Montreal, Que., Canada

Residence, ro Bayle Street, Montreal, Que., Canada

Dennis Camille Amedeé Galarneau was born July 26, I88I, in Holyoke, Mass., the son of George Amedeé Galarneau and Virginia (Robinson) Galarneau. On his father's side he is of French Canadian and on his mother's of French American ancestry. He has one sister, Aldina Anna Louise Galarneau, B.L.S. Simmons College.

He was prepared at the Holyoke (Mass.) High School and received the degree of B.A. from Tufts College in 1904. He was a member of Theta Delta Chi.

He was married June 29, 1910, in Boston, Mass., to Miss Marie Agnes May Papineau of Boston, daughter of Alfred Papineau and Josephine (Grabherr) Papineau, both deceased.

Galarneau has been assistant forester for the Canadian Pacific Railway of Montreal, Canada, since November, I9I2. He served in the United States Forest Service from July, I906, to January, I9I0, as forest assistant. He then became forester for John Fenderson \& Company of Sayabec, Quebec, which position he held until February, I9II, when he accepted an offer of employment in the Hampden Lumber Company, Springfield, Mass. In July, I9II, he was appointed cruiser for the firm of Clark \& Lyford, forest engineers of Vancouver, B. C., and from October, I9II, to November, I9I2, he held the same position in the firm of Lyford, Clark \& Lyford of Montreal.

$\mathrm{He}$ is a Roman Catholic.

\section{John D. Guthrie}

\section{Business address, United States Forest Service, Springerville, Ariz.}

John Dennett Guthrie was born July 15, 1878, in Charlotte Courthouse, Va., the son of Eppa Dennett Guthrie, captain of militia in the Civil War and later in the Confederate Army, and Nancy Kate (Franklin) Guthrie, daughter of John and Martha (Anderson) Franklin. On his father's side he is of Scotch-Irish ancestry, the earliest American ancestor being Henry P. Guthrie, who settled in what is now King and Queen County, Va., on a grant of land received from the King of England, in the latter part of the seventeenth century. The Guthrie family originated in Scotland and was so named by King David, who knighted a member 
of the family for a favor done him while he was traveling through the north of Scotland. His mother's family was closely related to the Earlys, Johnstons, Andersons, Langhornes and Lees of Virginia. He had one brother, Charles Calloway Guthrie, now deceased, and four sisters: Mrs. William McQuown Thompson of Garanhuns, Brazil, S. A., Mrs. Mason Wiley Jones of Shawsville, Va., Mrs. Richard Edmonds Moseley of Jeffress, Va., and Mrs. Elmo E. Gibbs of Charlotte Courthouse, $\mathrm{Va}$.

He was prepared at the Charlotte (Va.) High School and in 1902 received the degree of $\mathrm{Ph} . \mathrm{B}$. from Union College, where he was a member of Sigma Phi and editor of the college weekly and annual. After graduation from Union he was employed from 1902 to 1904 in the United States Forest Service in Tennessee, Maine, Texas, New Mexico, California and Utah.

He was married March 25, 1912, in Riverside Ranger Station, Greer, Ariz., to Susan Ruggles Pratt Church of Brooklyn, N. Y., daughter of Judge Calvin E. Pratt, of the New York Supreme Bench (deceased), and Susan Pratt.

Guthrie is supervisor in the United States Forest Service, in charge of the Apache National Forest, Arizona. From 1906 to 1908 he was forest assistant and in 1908 was made deputy forest supervisor. He received his present appointment the same year. He writes: "Work in the Forest Service of the Department of Agriculture since entrance in 1902 has taken me into Tennessee, Maine, Texas, New Mexico, California, Idaho, Oregon, Utah, Arizona and New Hampshire. Entered the Forest Service as a student assistant, then rose to assistant forest expert, forest agent, forest assistant, deputy supervisor and forest supervisor, with a graduation from $\$ 300$ per annum to $\$ 2,200$ per annum. Entered and was assigned to collection of figures on growth, then later in working plan work in Texas, Maine and New Mexico, then in forest extension, later in investigations, then boundaries, then administrative work, where I am at present."

$\mathrm{He}$ is a member of the Presbyterian church. Concerning politics, he writes that he is a "Progressive Democrat. Believer in tariff for revenue only, conservation of national resources, and federal control of same so far as possible, regulation of the trusts, purity in politics, the recall and referendum (even of the judiciary), national aid to good roads, one term (six years) for president, popular election of senators, the primary system and 
Woodrow Wilson for president." $\mathrm{He}$ is a member of the American Forestry Association, the Society of American Foresters, the American Academy of Political and Social Science, the National Geographic Society, the Concatenated Order of HooHoo, the National Conservation Association, the University Club of Washington, D. C., and the Sons of the American Revolution.

$\mathrm{He}$ has published articles in the Forestry Quarterly and American Forestry-among them, Spitzenber planting tools (in Quarterly) and A big tree grove in California. He has lately prepared an anthology of forest verse.

\section{James A. Howarth, Jr.}

Care of Indian Agent, Cloquet, Minn.

James Ashworth Howarth, Jr., was born July II, 1875, in New Haven, Conn, the son of James Ashworth Howarth, postmaster at New Haven since 1898, and Lilian Frances (Stevens) Howarth. $\mathrm{He}$ is of English descent on both sides of the family. $\mathrm{He}$ has two brothers: Harry - Arthur Stevens Howarth, Ph.B. Yale '99, and Thomas S. Howarth.

He was prepared at the New Haven High School and attended the Sheffield Scientific School at Yale during the year 1893-94. In 1896 he received the degree of LL.B. cum laude from the Yale Law School.

He was married July 8, 1907, in Flambeau, Wis., to Miss Eva Mary Cyr of Flambeau, daughter of Alex Cyr and Severine (Auger) Cyr.

From July I, I906, to December, I909, Howarth was forest assistant in the United States Forest Service, being assigned to the Indian reservations in Wisconsin and Minnesota. From December, I909, to July II, I9IO, he held the same position in the Superior National Forest, Minnesota. He was granted a year's leave of absence, during which time he was engaged in selling Duluth real estate. $\mathrm{He}$ was then transferred to the Indian Service and assigned as forest assistant to Fond du Lac Reservation, Minnesota. $\mathrm{He}$ is now superintendent in the Indian Service at Cloquet.

He writes: "Passed through the Spanish War without seeing any fighting as a sergeant in Captain Beach's Volunteer Battery C, Heavy Artillery, from New Haven. Was never ordered out of the state encampment at Niantic, Conn. Practiced law before and after the war in two New Haven offices, Case, Ely 
\& Webb and J. B. Ullman. Tried business a few years in New York and elsewhere. After graduating from the Forest School entered the United States Forest Service in 1906 and have since been employed in forestry work on Indian reservations in Wisconsin and Minnesota."

$\mathrm{He}$ is a member of Trinity Methodist Episcopal Church, New Haven.

Frederick W. H. Jacombe

Business address, Forestry Branch, Department of the Interior, Ottawa, Ont., Canada

Home address, Westboro, Ont., Canada

Frederick William Hudson Jacombe was born August 25, 1875, in Guelph, Ontario.

He was prepared at the Guelph (Ont.) High School and received the degree of B.A. from the University of Toronto in 1896 , and in 1898 the degree of M.A.

Jacombe is in the Forestry Branch of the Department of the Interior, Ottawa, Canada.

He was secretary and treasurer of the Canadian Society of Forest Engineers during the years 1908-12, and at the same time assistant secretary of the Canadian Forestry Association. $\mathrm{He}$ is a Free and Accepted Mason.

\section{Sydney L. Moore}

Business address, R. R. Sizer \& Company, National Bank Building, Savannah, Ga.

15 William Street, New York City

Sydney Luard Moore was born June 18, I882, in St. Louis, Mo., the son of Henry Walter Moore, editor and manager of daily newspapers in St. Louis and New York, and Sue (Vandegrift) Moore. His father prepared at the Gymnasium in Weimar, Germany, for entrance to the University of Jena, where he later studied. On his father's side he is of English and on his mother's of Dutch ancestry.

He was prepared at the public schools in St. Louis, Mo., and in 1904 received the degree of B.A. from Princeton University, where he was a member of Phi Beta Kappa and of the Princeton Campus Club. 
He was married January I, I9I0, in Denver, Colo., to Miss Frances Mary Hart of Denver, daughter of Dr. Charles N. Hart.

Moore resigned from the Forest Service, March I, I9I3, to enter the employ of R. R. Sizer \& Company, timber brokers, of New York City. He writes: "Entered the United States Forest Service July, 1906, as forest assistant and was assigned to the (then) Sawtooth National Forest, Idaho, and engaged in general forest administration, especially timber sales. In June, 1907, was assigned to the Lewis and Clarke National Forest, Montana, on timber reconnaissance in coöperation with the Northern Pacific Railroad Company. In February, 1908, was appointed forest inspector with headquarters at Denver, Colo. In December, 1908, was appointed assistant chief of silviculture, Forest Service, District 2, Denver. In 1909, was appointed assistant district forester, in charge of silviculture at Denver."

He is a member of the Episcopal church and in politics is an Independent. $\mathrm{He}$ was elected to Sigma $\mathrm{Xi}$ while at Yale and belongs to the Society of American Foresters. During the winter term, I9I3, he was the lecturer at the Yale Forest School on the organization and management of the National forests.

He has published: Regulating the annual cut of national forests, Proc. Soc. Am. Foresters, V, No. I, Washington, I9Io; Harvesting the annual seed crop, Am. For., XVII, No. 3, Washington, I9II; The equipment and operation of a German seed extracting establishment, For. Quart., IX, No. I, Cambridge, IgII.

\section{Andrew E. Oman}

\section{Weiser, Idaho}

Andrew Edward Oman was born June 27, 1877, in Leonardville, Kans., the son of Andrew P. Oman and Clara (Johnson) Oman. His father is a director of the school board and a farmer-active in church work and in the improvement of rural conditions. He is of Swedish ancestry. He has two sisters: Amanda (Oman) Larsen and Ella A. Oman; and four brothers: John W. Oman and Clarence Oman, who took courses at Kansas State Agricultural College, and Harry Oman and Victor E. Oman, recipients of the degree of B.S., Kansas State Agricultural College.

He graduated from the Kansas State Agricultural College in Ig00 with the degree of B.S. He served as a cadet while at college. Following his 
graduation he taught three winters in the public schools, working summers on the farm in partnership with his brother John.

$\mathrm{He}$ is unmarried.

Oman has been employed in the United States Forest Service as forest assistant with promotion as to salary, since July I, 1906, his headquarters since July, 1909, being in the Weiser National Forest, Idaho. He writes: "From July I, 1906, to July I, I909, worked in Washington, D. C., in the office of forest extension. From January I to March 12, I912, taught a ten weeks' term-ranger's short course in forestry-at Utah Agricultural College, Logan, Utah."

$\mathrm{He}$ is a member of the Swedish Lutheran church. In politics he is a "Republican by inheritance and choice" and is progressive in his views. He is a member of the Society of American Foresters, the American Forestry Association and the Weiser Commercial Club.

\section{Arthur D. Read}

Business address, Forest Service, Washington, D. C. Home address, Senorito, Sandoval County, N. Mex.

Arthur Davis Read was born October 26, I882, near Quincy, Ill., the son of William Everet Read and May R. (Davis) Read. On his father's side he is of early Puritan stock and his grandfather lived at Keene, N. H., before moving to Illinois. He has three brothers: Kenneth $\mathrm{C}$. Read, Howard S. Read and Leslie H. Read.

He was prepared at the public schools in Emporia, Kans., and in 1903 received the degree of B.A. from the College of Emporia.

$\mathrm{He}$ is unmarried.

Read is an examiner in the United States Forest Service. $\mathrm{He}$ is now in the Washington office working up results of the grazing reconnaissance in which he was engaged in 1912. His district headquarters is Albuquerque, N. Mex. From 1906 to 1908 he was forest assistant in the Service and supervisor from I908 to I9I0. In I9IO-II he was deputy supervisor, after which he received his present appointment.

$\mathrm{He}$ is a member of the Congregational church. Concerning politics he writes that he is an "insurgent Republican. Believe in the initiative, referendum and recall of judges." $\mathrm{He}$ is a member of the Society of American Foresters. 


\section{Arthur B. Recknagel}

Business address, Department of Forestry, Cornell University, Ithaca, N. Y.

Home address, 223 East Nineteenth Street, Flatbush, Brooklyn, N. Y.

Arthur Bernhard Recknagel was born December 15, 1883, in Brooklyn, N. Y., the son of John Hermann Recknagel, a commission merchant and president of the American Spice Trade Association, and Marie (Westermann) Recknagel (died May I, I890). He is the grandson on his father's side of Carl L. Recknagel and Elise (Löhning) Recknagel of Brooklyn, N. Y., and on his mother's side of Bernhard Westermann and Johanna (Brasch) Westermann of New York City. He has three brothers: Carl L. Recknagel, Jr., John H. Recknagel, Jr., and Harold S. Recknagel, Yale ' 98 and LL.B. Columbia 'or; and two sisters: Viola Recknagel and Friede Recknagel.

He was prepared at Bedford Military Academy, Great Neck, L. I., and Adelphi Academy, Brooklyn, N. Y., and in 1904 graduated from Yale College, where he was a member of Sigma $\mathrm{Xi}$ and of the Orations Baseball team and was the recipient of the Scott Prize in German.

He was married August 25, 1909, in Albuquerque, N. Mex., to Miss Mary Thomas Miller of Harrisonburg, Va., daughter of Lewis Caperton Miller and Ada (Pilson) Miller. They have one son, Bernhard Westermann Recknagel, born June II, 1912, in Dresden, Germany.

Recknagel is professor of forestry in the New York State College of Agriculture at Cornell University, Ithaca, N. Y., where he teaches forest management, forest utilization and wood technology. He has held this position since February I, I9I3. He writes: "On entering the Forest Service as forest assistant in 1906 my first assignment was to Santa Fé, N. Mex., where I was engaged in timber sale examinations on the Jemez, Carson and Pecos National forests. Transferred in November to the Beaver National Forest, Utah, for similar work, and again to the Coconino National Forest, Flagstaff, Ariz., in December, where I remained on growth studies (western yellow pine), marking and estimates until the end of June, 1907 , when I was ordered in to Washington for timber sale detail. In September and again in December I was in Georgia on congressional tours and in Tennessee on a woodlot examination. In January I was made acting chief of the reorganized section of reconnaissance, office of management. This appointment was confirmed in February and in April I started on a four months' trip to organize 
the new field work. This trip carried me to New Mexico, Colorado, Utah, Wyoming, Montana, Idaho and Washington. I returned to Washington, D. C., over the Canadian Pacific from Vancouver to Montreal. During August I was in Alabama on congressional tours and also conferred with the governors of Alabama and of Georgia as to Service coöperation with these states. In December I left Washington to take up my duties in District 3 as assistant chief of silviculture, remaining there for nearly three years or until October, I9II, when I sailed for Europe on a year's leave of absence to study forest conditions abroad.

"The fall semester I enrolled at the Forst Akademie at Eberswalde, near Berlin, then I traveled through Germany, France, Switzerland and Austria. I became especially interested in the management: i. e., in the working plan practice of the various countries, and, on settling at Dresden for some months, specialized on this subject, having the Forst Akademie at Tharandt conveniently near.

"Again and again it has been brought home to me that the experiences we are making and the stages through which we are passing are nothing new but merely the inexorable repetition of history modified by changed economic conditions. But great as has been the progress made by European nations in the science of forestry, it has not resulted in stagnation. New ideas and improvements on old methods are constantly being introduced and all this makes for progress towards the ideal forestry which is, apparently, as far removed from realization in Europe as it is in America.

"This progress of present day forestry in Europe is best exemplified, it seems to me, by the turning away from pure stands and artificial regeneration toward mixed stands and natural regeneration. Throughout Prussia the beech is being coaxed back among the Scotch pine stands. Saxony, where spruce was raised in pure stands for successive generations, has realized that this repetition of the same crop, however profitable, soon exhausts the soil.

"Another striking example of this progress is Professor Wagner's 'Blendersaumschlag' or Border Cuttings, whereby he regenerates naturally under shelter working from the northern 
side, where is the maximum of sun and wind protection, towards the southern side of the stand.

"In methods of artificial regeneration what struck me particularly is the abandoning of the many complex planting instruments in favor of that simplest of all tools, the mattock. No more jamming of the seedling into the earth with crumpled, often injured root system, but a 'natural,' normal planting by hand in a mattock-made hole.

"Finally I must mention the tendency away from large cutting areas with their attendant increased dangers of fire, drought, insects, fungi, wind, etc., towards smaller cutting areas and more of them: more points of attack as initial points in a well-planned cutting series progressing against the prevailing wind direction."

Recknagel is an Episcopalian, and in politics is a Republican. He was at one time a member of Company C, First Regiment of Arizona Militia. He is a member of the Society of American Foresters.

He has published: Practical fire protection, For. Quart., 1906, reprinted in Forest Leaves, $\mathrm{Pa}$., 1906; Economics of protection, Forest Leaves, I906; The new reconnaissance, Proc. Soc. Am. Foresters, 1908, reprinted as pamphlet, Yale Pub. Ass'n, 1909; Marking in practice, For. Quart., 1909; Progress of reconnaissance, For. Quart., I910; Example of a German working plan, a translation, For. Quart., I9II; Nomenclature of divisions of area in working plans, open letter, For. Quart., I912; Prussian seed extracting establishments, For. Quart., I912; The forests of northern Russia, a review, For. Quart., I912; (With T. S. Woolsey, Jr.) European study for foresters, For Quart., I9I2; Border cuttings, a suggested departure in American silviculture, Proc. Soc. Am. Foresters, 1912; Four open letters to the Yale Forest Club, Am. For., 1912; (With I. F. Eldredge) Management of longleaf pine with special reference to the turpentine industry, Circ., U. S. Forest Service, 1912; The theory and practice of working plans, N. Y., John Wiley \& Sons, 8vo, x +230 pp., illus.

\section{Alexander H. D. Ross}

Business address, Department of Natural Resources, Canadian Pacific Railway, Calgary, Alta., Canada

Home address, 32 Kendal Avenue, Toronto, Ont., Canada University of Toronto, Toronto, Ont., Canada

Alexander Herbert Douglas Ross was born March 18, 1865, in Carlton Place, Ontario, the son of Walter Ross, a Presbyterian minister, and 
Elisabeth (Burrowes) Ross. On his father's side he is of Scotch Canadian and on his mother's of English and Irish ancestry.

He was prepared at the Carlton Place High School and Kingston Collegiate Institute and received the degree of B.A. from Queen's University in I 888 and in I 889 the degree of M.A. Following his graduation from college he taught for thirteen years in the Ontario high schools and the Collegiate Institute. His specialty was mathematics and natural science.

$\mathrm{He}$ is unmarried.

In 1906-07 Ross was technical assistant in the Forestry Branch of the Department of the Interior, Ottawa, Ontario. In October, 1907, he was appointed lecturer in forestry at the University of Toronto, which position he still holds. $\mathrm{He}$ is also consulting forester in the Department of Natural Resources of the Canadian Pacific Railway, Calgary, Alberta. $\mathrm{He}$ received this appointment in May, 1912.

$\mathrm{He}$ is a member of the Presbyterian church and in politics is a liberal Conservative. In 1887 he was color sergeant in the Princess of Wales Own Rifles, Kingston, Ontario. He is a Mason of the Grand Lodge of Canada and a member of the Independent Order of Odd Fellows, Grand Lodge of Ontario.

He has written numerous articles on forestry for the Canadian Magazine, Canadian Courier, Canadian Forestry Journal, etc., and for the bulletins of the Dominion Forest Service.

\section{Robert Y. Stuart}

Business address, Unitcd States Forest Service, Washington. D. C.

Robert Young Stuart was born February 13, I883, in Carlisle, Pa., the son of William Chalmers Stuart and Janet (Morris) Stuart. He is of Scotch-Irish ancestry. He has one brother, Hugh Patterson Stuart, Ph.B. Dickinson 'o3, and one sister, Helen Beecher Stuart, who took a special course in music at Wilson in Igrr.

$\mathrm{He}$ was prepared at the Carlisle ( $\mathrm{Pa}$.) High School, and received the degree of B.A. in 1903 from Dickinson, where he was a member of Phi Delta Theta and Raven's Claw. He spent the summer of 1903 in travel abroad and from October, 1903, to June, 1904, was traveling sales agent for the Aluminum Cooking Utensil Company of New Kensington, Pa. In 1906 he received an M.A. degree from Dickinson.

He was married December 9, 1907, in Harrisburg, Pa., to Miss Janet Wilson of Harrisburg, daughter of David Wilson (deceased) and Frances Wilson. 
During July, August and September of 1905, before graduating from the Yale Forest School, Stuart served as forest student in the United States Forest Service. In July, 1906, he was appointed forest assistant, which position he held until January I, I908, when he became forest inspector. From December I, I908, to January I, I9I0, he was assistant chief of operation, District $\mathrm{I}$. He then received the appointment of district forester of the same district with headquarters in Missoula National Forest, Montana. In January, 1913, he was appointed forest inspector in the department of silviculture in the Washington, D. C., office.

$\mathrm{He}$ is a member of the Episcopal church. He is a member of the Society of American Foresters, the Concatenated Order of Hoo-Hoo, and is a Mason.

\section{Horace F. Studley}

Business address, Studley Box \& Lumber Company, Rochester, N. H. Home address, Rockland, Mass.

Horace Franklin Studley was born April 10, 1882, in Rockland, Mass., the son of Gideon Studley and Hannah Elizabeth (Totman) Studley.

He prepared at the Rockland (Mass.) High School and received the degree of B.A. at Harvard in 1905.

$\mathrm{He}$ is unmarried.

Studley writes: "After my graduation from the Yale Forest School in June, 1906, I was in the Forest Service until May, I9II (with the exception of the year from July $\mathrm{r}$, I908, to July I, 1909). I spent about a year as a forest assistant on the Uinta National Forest in Utah. In the winter of 1907-08 I was a special agent in the bureau of corporations, doing work in Texas, Arkansas and Mississippi. In July, I909, I was made deputy forest supervisor on the Uinta Forest and in November, I909, was made acting supervisor of the Nebo Forest in Utah and supervisor in January, I9I0. I remained as supervisor of the Nebo Forest until May I, I9II, when I resigned to take a position as salesman with the Studley Box \& Lumber Company of Rochester, N. H.

He has published: Uncle Sam's forest rangers, Tourists' Mag., N. Y., May, I9II. 


\section{W. Hoyt Weber}

Business address, 381 Fourth Avenue, New York City

Home address, I5I Courtland Avenue, Stamford, Conn.

William Hoyt Weber was born April 7, 1881, in New York City, the son of George Adam Weber, president of the Weber Rail Joint Company, now director of the Rail Joint Company, and Annie (Hoyt) Weber. He is the grandson on his father's side of John Harrison Weber and Caroline (Hoke) Weber, and on his mother's of William Hoyt and Mary (Cahoon) Hoyt. He has three sisters: Caroline Hoke (Weber) Luther, Helen H. (Weber) Howe and Muriel (Weber) Foote.

He was prepared at King's School, Stamford, Conn., and with a tutor, and received the degree of B.A. in 1903 from Wesleyan University, where he was a member of Psi Upsilon.

He was married April 2I, I908, in Mount Vernon, N. Y., to Miss Helen Elitha Roberts of Mount Vernon, daughter of Hiram Lane Roberts and Helen (Lamb) Roberts. They have one daughter, Helen Elethia Weber, born February 13, 1909, in Stamford, Conn.

Weber is vice president of the Munson-Whitaker Company, a forestry concern of New York City. He has been with this company since February, 1908. In 1907-08 he was consulting forester and in 1908 spent some time with the Gunn Richards Company, public accountants, studying business methods.

He was formerly a Methodist, but is at present a member of a union chapel in a nearby town. He is a member of the Society of American Foresters, the Psi Upsilon Club of New York City and the Concatenated Order of Hoo-Hoo. He is Secretary of the Class of 1906, Yale Forest School.

\section{George A. Wilmot}

Office of the Jokai Retreat, Union of South Africa

George Adelbert Wilmot was born in 1877 in Dublin, Ireland.

He was prepared at St. Aiden's School, Grahamstown, South Africa, and at St. Mary's School, Canterbury, England. In I895 he was graduated at the University of the Cape of Good Hope and in 1896 at Katwijk, Holland.

After graduation from the Yale Forest School in I906 Wilmot became an instructor in the Forest School at Cape Town, South Africa. He is now reported to be in the office of the Jokai Retreat, but has furnished no information for this record. 
Graduate holding Certificate but not Degree

\section{Rudo L. Fromme \\ Olympia, Wash.}

Rudo Lorenzo Fromme was born July 10, 1882, in Saint Paris, Ohio, the son of Frank W. Fromme, advertising manager for some years for Gaar Scott \& Company (manufacturers of threshing machines) of Richmond, Ind., and Stella L. (Riker) Fromme. On his father's side he is of German and Spanish and on his mother's of German and Scotch ancestry. He has one brother, Fred Denton Fromme, B.S. South Dakota State Agricultural College 'II, and one sister, Nola Katheryn Fromme, B.S. Ohio State University 'o5.

He was prepared at the high school in Richmond, Ind., and during the year I90I-02 attended Purdue University, Lafayette, Ind. In 1905 he received the degree of B.S. from Ohio State University, where he was a member of Alpha Gamma Rho. He spent three months in the summer of 1905 as forest student.

He was married May 20, 1908, in Priest River, Idaho, to Miss Ruby Ellen Gowanlock of Priest River, daughter of John A. Gowanlock and Mederise Gowanlock.

Fromme has been supervisor of the Olympic National Forest with headquarters in Olympia, Wash., since September I, I9I2. On August 16, 1912, he wrote: "Since leaving Yale I have traveled but very little excepting on official business connected with the Forest Service. My first assignment after leaving Washington, D. C., was to the old Priest River National Forest in Northern Idaho as forest assistant, where I spent the summer of 1906 on and in the vicinity of Priest Lake, mostly fighting fires, carrying tools and supplies by row or sail boat up the lake and then packing them back into the mountains on my back. During the fall and winter I estimated timber, and later put through the first large commercial sales on that, now the Kaniksu, forest. In August, 1907, when Supervisor McConnell was dismissed, I was placed in charge of the Kaniksu and my headquarters changed to Newport, Wash. On May 20, I908, I married my present wife, who was then residing with her parents in Priest River, Idaho, and in the latter part of September, same year, we disposed of most of our newly purchased furniture in order that I might accept a new assignment as chief of operation in the San Francisco district office, obtaining 
a temporary detail of six or seven weeks in Washington, D. C., while en route. While in San Francisco, seven months, I had occasion to visit almost all of the forest headquarters and some of the forests proper of California, accepting an assignment as supervisor of the Klamath National Forest to supersede acting superintendent Harley in July, 1909. After one year in charge of the Siskiyou National Forest in Southwestern Oregon, I am now to leave in two or three days to take charge of the Olympic National Forest of Western Washington, a more important forest and a bigger job."

In politics he is a "Progressive, generally Republican." He is a member of the Society of American Foresters, the Geological Society, the American Forestry Association and the Concatenated Order of Hoo-Hoo.

\section{Non Graduates}

Ford D. Bacon

Harveyville, $\mathrm{Pa}$.

Ford Dorrance Bacon was graduated from Bucknell University in 1904. He attended the Yale Forest School in 1904-05. He has furnished no information for this record.

\section{*Jacob F. Bitner}

Died 19I2

Jacob Foster Bitner was born July 5, 1883, in Penn Hall, Center County, $\mathrm{Pa}$, the son of Joseph $\mathrm{K}$. Bitner, a retired farmer of Spring Mills, Pa., and Elizabeth P. (Fetterolf) Bitner. A sister, Jennie Coburn Bitner, survives him.

He was prepared at Spring Mills ( $\mathrm{Pa}$.) Academy and in 1904 graduated from Franklin and Marshall College.

He was unmarried.

After leaving the Yale Forest School Bitner taught one term at the Center Hall (Pa.) High School and was agent for the Morris Cigar house, later becoming agent for the Capewell Horse Nail Company of Hartford, Conn. He was employed for a time on 
the United States Geological Survey and during this period worked in Alabama, Tennessee, Kentucky, Indiana, Ohio, West Virginia, Illinois and Michigan. On September I, I9II, he accepted the position of wholesale agent for the Racine Lumber and Manufacturing Company of Racine, Wis., which he held at the time of his death. He had been on the road as a salesman seven years and during this time had traveled extensively.

He was a member of the German Reformed church and in politics was a Republican. He belonged to the Independent Order of Odd Fellows.

He died February 20, 1912, in the Borgess Hospital, Kalamazoo, Mich., and was buried in Penn Hall, Center County, Pa.

\section{Edward G. Cheyney}

\section{Business address, University Farm, St. Paul, Minm.} Residence, 21 16 Knapp Street, St. Paul, Minn.

Edward Gheen Cheyney was born November 24, 1878, in Washington, D. C., the son of Rufus T. Cheyney, of the United States Navy Department, and Lucie Marie de Brunin (de Bolmar) Cheyney. On his father's side he is of English and on his mother's of French and French-Canadian ancestry. His maternal grandfather was an aide of Napoleon at the battle of Waterloo. He has one brother, Charles Bolmar Cheyney, B.A. Yale '95 and M.A. '04.

He was prepared at Western High School, Washington, D. C., and received the degree of B.A. in 1900 from Cornell University, where he was a member of Alpha Zeta. In the year I900-or he was employed by the Deering Harvester Company of Chicago, I1l., and in I90I-02 with the Baltimore \& Ohio Railroad at Brunswick, Md. In 1902-03 he tutored in Apalachicola, Fla., and from July, 1903, to October, 1904, was student assistant in the Forest Service.

He was married September II, I907, in Apalachicola, Fla., to Miss Harriet Frances Porter of Apalachicola, daughter of R. H. Porter. They have two daughters: Virginia Brunin Cheyney, born July 16, 1908, in Apalachicola, Fla., and Lucie Marie Cheyney, born September 7, 1909, in Apalachicola.

In 1905-06 Cheyney was assistant and the next year instructor in forestry in the University of Minnesota. In 1907 he was made assistant professor and in I9I I was appointed professor of forestry and director of the College of Forestry, his present position. 
In politics he is a Progressive Democrat. He was secretary of the Minnesota State Forest Association from 1906 to 1912 and since 1912 has been a member of the State Forestry Board. $\mathrm{He}$ is a member of the Society of American Foresters, the National Geographic Society, the Minnesota Forestry Club and the Campus Club of the University of Minnesota.

He has written articles for the Forestry Quarterly and for Forestry and Irrigation and for three years was editor of the Minnesota Forester.

\section{Galen S. Cleland}

Wells, York County, Maine

Galen Snow Cleland attended the Yale Forest School in 1904-05. After leaving the School he was engaged in private work in Calais, Maine, and from January to October, 1907, he was with the Laurentide Company, Grand Mere, Canada. He has furnished no information for this record.

\section{Walter O. Filley}

Business address, Connecticut Agricultural Experiment Station, New Haven, Conn.

Residence, r44 Whalley Avenue, New Haven, Conn.

Walter Owen Filley was born July 27, 1877, in New Haven, Conn., the son of Myron W. Filley (deceased), a photographer, and Cleora (Gilbert) Filley. His father's ancestors came to Windsor, Conn., in 1632, and his mother's settled in New Haven in 1638 . He has one brother, Homer G. Filley, and three sisters: Mary E. (Filley) Wanamaker, Lovella C. Filley and Sara W. (Filley) Chatfield.

$\mathrm{He}$ is a graduate of the Hillhouse High School, New Haven, Conn. Before entering the Yale Forest School he spent ten years in the photographic business, including eighteen months with the Eastman Kodak Company, Rochester, N. Y.

$\mathrm{He}$ is unmarried.

Filley was at one time acting state forester of Connecticut. He afterward became assistant instructor in the Yale Forest School and later assistant in forestry at the Connecticut Agricultural Experiment Station. He became assistant state forester in October, I9I I, and in September, I912, state forester. 
$\mathrm{He}$ is a member of the United (Congregational) Church of New Haven, Conn., and in politics is a Progressive. He served four years in the Naval Battalion, C. N. G., and three months in the Volunteer Navy, U. S. A. He is a member of the Society of American Foresters, the United Spanish War Veterans and the Patrons of Husbandry.

\section{*Gay E. Hills}

Died I9II

Gay Elijah Hills was born September 5, I882, in Swanzey, N. H., the son of Calvin Elijah Hills and Anna (Gay) Hills.

He was prepared at Keene (N. H.) High School, and in 1904 received the degree of B.A. from Dartmouth College.

He was married November 17, I9II, in Swanzey, N. H., to Miss Daisy Dawson of New York City, daughter of Walter Augustus Dawson and Kate C. Dawson.

After leaving the Yale Forest School, Gay was employed by the Trumbull Electric Company of Plainville, Conn.

He died November 19, I9I I, at his home in Swanzey, N. H.

\section{Elmer R. Hodson}

\section{United States Forest Service, Ogden, Utah}

Elmer Reed Hodson was born June 2, 1875, in Salem, Iowa, the son of James Lindsay Hodson and Anna Mariah (McGriff) Hodson. He is the grandson on his father's side of George Hodson and Rebecca (Osborn) Hodson, and on his mother's side of James McGriff and Mary (Reed) McGriff. He is of English and Scotch ancestry. $\mathrm{He}$ has one sister, Lulu Hodson, and one brother, Eugene Hodson.

He received the degree of B.S. from the Iowa State College in I898, and in 1900 the degree of M.S.

$\mathrm{He}$ is unmarried.

Upon entering the United States Forest Service in June, I905, Hodson was appointed forest assistant. $\mathrm{He}$ is at present forest examiner with headquarters in Ogden, Utah. He writes: "Have traveled in the South and West mainly, since leaving Yale. In 1905 was in the Carolina pine belt, in 1906 in New Mexico and Colorado, in 1907 in Montana and Wyoming and 
in 1908 again in Colorado. In December, 1908, was stationed at Ogden, Utah, headquarters of District 4, in charge of silvics."

In politics he is a Progressive Republican. He is a member of the Society of American Foresters and is a Mason.

He has published a few articles in Bulletin $7 I$, U. S. Forest Service.

\section{J. Osborne Hopwood}

Business address, Central High School, Philadelphia, Pa. Home address, Primos, Delaware County, $\mathrm{Pa}$.

James Osborne Hopwood was born November 6, 1879, in Philadelphia, Pa., the son of John H. Hopwood and Rebecca J. (Scott) Hopwood. $\mathrm{He}$ is of English ancestry on both sides of the family. He has two brothers: Arthur M. Hopwood and John H. Hopwood, Jr.

He was prepared at the Philadelphia schools and attended Cornell University one year. In 1904 he received the degree of B.S. from the University of Pennsylvania and in 1907 the degree of M.S. from Yale University.

He was married June 20, 1907, in Philadelphia, Pa., to Miss Josephine L. Reed of Philadelphia, daughter of Orville Reed and Mark Anna (Leeds) Reed. They have two daughters: Josephine Lindsay Hopwood, born July 6, 1908, in Marion, Ind., and Margaret Scott Hopwood, born December 7, 1910, in Philadelphia, $\mathrm{Pa}$.

During the year 1906-07 Hopwood was chemist and forest adviser to the Publishers Paper Company of Portsmouth, N. H. In 1908 he was appointed head of the department of biology of the Marion Normal College, Marion, Ind. Since 1909 he has been a teacher of natural sciences in the Central High School, Philadelphia, $\mathrm{Pa}$.

$\mathrm{He}$ is a member of the Teachers Association of Philadelphia.

$\mathrm{He}$ has written an article: Legislation on measurement of logs for "Graves forest mensuration," N. Y., John Wiley \& Sons, 1907.

\section{Thomas P. Ivy \\ Conway Center, N. H.}

Thomas Parker Ivy was born December 20, 1855, near Warsaw, Ala., the son of James Blow Ivy (died in 1872) and Sarah Evans (Reynolds) Ivy (died in 1909). His father was born near Norfolk, Va., in 1818, and 
was a cotton planter and slaveholder with a plantation on the Tombigbee River, Alabama. He also assisted in the construction of the fortification around Mobile, Ala., for the Confederate Government. His mother was born in Williamson County, Tennessee, in 1818 , daughter of Sherman Reynolds and Sarah (Parker) Reynolds. He has three brothers living: B. R. Ivy, William T. Ivy and Jesse C. Ivy, B.A. Harvard '74, LL.B. '76.

He received a B.A. at Harvard in $188 \mathrm{I}$ and for many years was engaged as a private banker in Atlanta, Ga. Ill health, superinduced by a sunstroke, forced him to give up banking.

He was married in I893 in Lowell, Mass., to Miss Julia Dalton Nesmith of Lowell, Mass., daughter of the late Hon. John Nesmith, lieutenant governor of Massachusetts, and Harriet (Mansur) Nesmith.

Since leaving the Yale Forest School, Ivy has been engaged in forest engineering in Conway Center, N. H.

$\mathrm{He}$ has published a pamphlet, the forestry problem in the United States, and various addresses on the subject of forestry.

\section{John E. Keach}

Business address, Forest Service, Washington, D. C.

John Everett Keach was born July 4, 1874, in Northampton, Mass., the son of John Keach and Ellen Maria (Jackson) Keach. His father served in the Civil War, 18th Connecticut, from 1862 to 1864 . $\mathrm{He}$ is the grandson of John $\mathrm{H}$. Keach and Harriett (Young) Keach of Danielson, Conn. He has two brothers: Merrill Henry Keach, and Walter Edmund Keach, who attended the Sheffield Scientific School at Yale from 1902 to 1906 .

He was prepared at the Northampton High School and at Andover and in 1900 received the degree of B.A. from Yale.

He was married December 26, I907, in Boston, Mass., to Miss Alice Belle Ricker, Smith '98, of Falmouth, Maine, daughter of Wentworth Pottle Ricker and Dorcas Ann (Merrill) Ricker (now Mrs. Barker). They have one son, John Ricker Keach, born June 24, 1909, in Missoula, Mont.

Keach has been an assistant in the United States Forest Service since graduating from the Yale Forest School. He writes: "Since leaving Yale Forest School I have served as forest assistant on the following national forests: Absaroka in Montana, Payette in Idaho, Helena in Montana, Medicine Bow in Wyoming, and Arkansas in Arkansas. In 1908 was transferred to office work, District I, Missoula, Mont. In I9Io was trans- 
ferred to Saranac Nursery, Lolo National Forest, Montana; in Igr I to Boulder Nursery, Helena National Forest, Montana, and St. Joe National Forest, Idaho; and in 1912 to Boulder Nursery, Helena National Forest." In 1913 he took his present position as assistant on the Lolo National Forest in Montana.

$\mathrm{He}$ attends the Congregational church and is a member of the Society of American Foresters.

\section{Albert H. Pierson}

Business address, United States Forest Service, Washington, D. C.

Albert Halsey Pierson was born October 5, 1877, in East Orange, N. J., the son of Albert Fleming Pierson and Adelaide (Decker) Pierson. He is the grandson on his father's side of Albert Pierson and Jane (Armstrong) Pierson and is of Scotch-Irish ancestry. On his mother's side he is the grandson of John Williams Decker, son of Alfred Decker and Kezia (Adams) Decker, and Maria Louisa (Haws) Decker.

He was prepared at Newark Academy, Newark, N. J., and in 1899 graduated from Princeton University with the degree of B.A. He then spent one year in a law office, one year with a business firm in New York and about two years at Biltmore Forest School and abroad. From October, 1903, to July, 1904, he served as forest student in the Forest Service.

He is unmarried.

Since September, 19I0, Pierson has been statistician in forest products in the Department of Agriculture, Washington, D. C.

$\mathrm{He}$ is a member of the Princeton Club of New York.

\section{W. Kerr Rainsford}

Business address, 40 Central Street, Boston, Mass.

Home address, Ridgefield, Conn.

Rainsford is with Allen \& Collens, architects, Boston, Mass.

\section{Jerome H. Ramskill \\ Delta, Colo.}

Jerome Hinds Ramskill was born August II, I880, in Chicago, Ill., the son of William F. Ramskill and Addie M. (Hinds) Ramskill. On his 
father's side he is of English, and on his mother's of Scotch-Irish ancestry. He has one sister, Emily H. Ramskill.

He spent his early days in Maryland and Washington, D. C., where he attended high school. In 1902 he entered Cornell, continuing to study there until the Forest School was discontinued in I903.

He was married February 28, 1906, in Parowan, Utah, to Miss Jessie Messick of Westerville, Ohio, daughter of Rufus M. Messick and Mary Frances Messick. They have two daughters: Margaret H. Ramskill, born December 19, I906, in Parowan, Utah, and Ruth Anna Ramskill, born November 23, 1912, in Delta, Colo., and one son, Jerome Hinds Ramskill, Jr., born April 23, I9I I, in Delta, Colo.

Ramskill was appointed forest assistant in the United States Forest Service on July I, I905, and was assigned to Sevier Forest Reserve, Utah. He was transferred in August, 1906, to Leadville National Forest, Colorado, and in November, 1907, to Uncompahgre National Forest, Colorado, which position he now holds.

$\mathrm{He}$ is a member of the Benevolent and Protective Order of Elks.

\section{Charles A. Scott \\ 311 North Eighteenth Street, Manhattan, Kans.}

Charles Anderson Scott was born January 30, 1875, in Westmoreland, Kans., the son of Adam Scott, a farmer, and Elizabeth (Anderson) Scott. His parents came to the United States from Scotland in 1870 . He has two brothers: Thomas A. Scott, M.D. Rush Medical College, Portland, Ore., and John M. Scott, B.S.A. Kansas State Agricultural College, now vice director of the Florida Experiment Station, Gainesville, Fla.

He lived on a farm and attended the common school at Westmoreland, Kans. In Igor he graduated from the Kansas State Agricultural College with the degree of B.S.A. He was a cadet captain while at college and a member of Alpha Zeta. He was employed in the United States Forest Service from the time of his graduation until he entered the Yale Forest School.

He was married September 30, I903, in Hall's Summit, Kans., to Miss Laura Davidson (deceased), of Hall's Summit, Kans., daughter of Isaac Davidson and Mary Davidson. He was married a second time, on January 30,1907 , to Miss Perley Burnham Jewett of Broken Bow, Neb., daughter of Leander Hastings Jewett and Sarah M. Jewett. By this marriage he has two daughters: Sybella Adelaide Scott, born January 4, 1908, in Broken Bow, Neb., and Sarah Elizabeth Scott, born January 13, I9II, in Manhattan, Kans. 
Scott is state forester and professor of forestry at the Kansas State Agricultural College, which positions he has held since June I, 1910. He was forest assistant in the United States Forest Service in 1905 and forest supervisor from 1906 to December 31, 1907, when he became professor of forestry at Iowa State College. This position he held until his present appointment.

$\mathrm{He}$ is a member of the Congregational church. He is a Progressive. He is a member of the Society of American Foresters and is a Mason.

He has written articles for Forestry and Irrigation and for numerous farm papers. He has also published articles in Bulletin 120 of the Iowa Experiment Station in Ames, Iowa, in 1910, and in Circulars 10, 13 and 20 of the Kansas Experiment Station, Manhattan, Kansas, in I9II-I2.

\section{Alpheus O. Waha \\ United States Forest Service, Albuquerque, N. Mex.}

Alpheus Oliver Waha was born August 27, 1881, in Erie, Pa., the son of Charles H. Waha and Emma (Boitz) Waha. He is of German ancestry. He has three sisters: Nell, Bessie and Grace Waha, and three brothers: Leroy, Raymond and Howard Waha, B.S. Pennsylvania State University.

He was prepared at the Erie High School, after which he worked with a manufacturing concern for two years. In 1901 he attended the Yale Summer School of Forestry, and in the fall of the same year entered the Bureau of Forestry, where he worked as a student assistant in Maryland, Tennessee, New York, Maine, Texas and Alabama until 1904, when he entered the Yale Forest School.

He was married January 12, 1910, in Albuquerque, N. Mex., to Miss Mary Simms of Herkimer, N. Y., daughter of George Simms and Charlotte (Snell) Simms. They have one daughter, Barbara Waha, born June II, 1912, in Albuquerque, N. Mex.

Waha is assistant district forester in the United States Forest Service with headquarters in Albuquerque, N. Mex. From July I, 1905, to April 30, 1907, he acted as forest assistant, being assigned to Gila National Forest, New Mexico. In May, 1907, he was appointed forest inspector of District 3, which position he held until December, 1908, when he received his present appointment. 
$\mathrm{He}$ is a member of the Lutheran church and in politics is a National Progressive.

\title{
John P. Wentling
}

\author{
Business address, University Farm, St. Paul, Minn.
} Residence, 2160 Carter Avenue, St. Paul, Minn.

Knox, $\mathrm{Pa}$.

John Philip Wentling was born February 2, 1878, in Knox, Pa., the son of Eli Wentling and Christina (Barlett) Wentling. $\mathrm{He}$ has three sisters and two brothers: Martha Ella Hugus, Melissa Cathrine Barlett, Anna Agnes Sheasley, Edward Henry Wentling and Charles Alvin Wentling.

$\mathrm{He}$ was prepared at the Clarion ( $\mathrm{Pa}$.) College Institute and was graduated at Franklin and Marshall College, Lancaster, $\mathrm{Pa}$., in 1902. Previous to his college course he was a teacher in the public schools. After graduation from college he entered government work in forestry and worked in various parts of the United States until he entered Yale.

He was married December 27, 1906, in Washington, D. C., to Miss Evelyn Price of Washington, D. C., daughter of Robert H. Price and Lucy A. Price. They have one daughter, Margaret Evelyn Wentling, born December 4, 1907, in Washington, D. C., and one son, John Philip Wentling, Jr., born September I4, I9II, in Park Rapids, Minn.

In 1905-06 Wentling was forest assistant in the United States Forest Service. In 1906 he was appointed professor of forestry at the Pennsylvania State Forest Academy, which position he held until 1908, when he became assistant professor of forestry at the University of Minnesota. In I9I2 he was made associate professor, his present rank. From September, I912, to April, 1913, he was in charge of the chestnut wood utilization, for the Pennsylvania Chestnut Blight Commission, during which time he was on leave from the University of Minnesota.

$\mathrm{He}$ is a member of the Reformed Church in the United States. $\mathrm{He}$ is a member of the Society of American Foresters, Sigma $\mathrm{Xi}$, the Pennsylvania and Minnesota Forestry associations, and the Forestry, Campus and Science clubs of the University of Minnesota.

He has written Farm forestry (in collaboration), an article in the L. H. Bailey series; articles for the circulars of the Forest Service; and has delivered addresses which were published in various lumber journals in $1905-06$. 


\section{Leslie L. White}

Vernal, Utah

Leslie Leroy White was born in $188 \mathrm{I}$ in Oskaloosa, Iowa.

He received the degree of B.S. at Pennsylvania College and studied at the Cornell Forestry School one year before coming to Yale.

$\mathrm{He}$ is married and has one daughter.

After leaving the Yale Forest School in 1905 White entered the Bureau of Forestry and was assigned to District 4, where he was engaged in silvicultural work. He left the United States Forest Service in April, I9I I, and has furnished no information for this record. 


\section{CLASS OF 1907}

Graduates holding Degree of M.F.

\section{William B. Barrows}

Business address, United States Forest Service, Washington, D. C. Home address, Croton on Hudson, N. Y.

William Burnett Barrows was born June 13, 1885, in Mathewson, Kans., the son of William Kent Hayes, at one time postmaster at Parsons, Kans., and now connected with the Parsons Water Supply \& Power Company, and Caroline Alabama (Burnett) Hayes. $\mathrm{He}$ is of Scotch and English ancestry. $\mathrm{He}$ is the adopted son of Samuel June Barrows, B.D. Harvard Divinity School '75 and D.D. Howard University, Washington, '97, of English and Huguenot ancestry, and Isabel Chapin (Hayes) Barrows, sister of William Kent Hayes. Samuel Barrows is an excongressman and clergyman; he represented the United States on the International Prison Commission in 1896 and was corresponding secretary of the Prison Association of New York in 1900. He has two sisters: Janet (Hayes) Davis, a graduate of Teachers College, Columbia University, and Anna Gibb Hayes; and one brother, Edgar Burnett Hayes, a graduate of the University of Kansas. He has an adopted sister, Mabel Hay (Barrows) Mussey, a graduate of Radcliffe College; also a stepsister, Helen Margaret Hayes, and two step-brothers: Robin Leslie Hayes and Alfred Leslie Hayes.

He was prepared at the Edward Everett School, Boston, Mass., the Boston Latin School, the Mechanic Arts High School, Boston, and the Hotchkiss School, Lakeville, Conn. In 1905 he received the degree of B.A. from Columbia University.

$\mathrm{He}$ is unmarried.

Barrows has been forest assistant in the United States Forest Service since July I, I907, and is at present in charge of the section of forest measurements in the Washington office. He spent the greater part of the summer of 1912 with E. H. Frothingham, a graduate of the University of Michigan, in a study of hemlock and northern hardwoods in the Lake States. He writes: "I spent seven months during the summer of 1909 in Montana estimating timber. During I9I2 I spent four months studying the results of forest planting in the East and Middle West." 
Concerning politics, he writes: "Am independent in politics, prejudiced against all conservative and reactionary policies." $\mathrm{He}$ is a member of the Concatenated Order of Hoo-Hoo.

\section{Avila Bédard}

\section{Business address, Parliament Buildings, Quebec, Canada} Residence, 574t/2 St. John Street, Quebec, Canada

Jaseph Avila Bédard was born June 6, I884, in Sainte Anne de la Pérade, Quebec, the son of Timothée Misaël Bédard, a hardware dealer, and Mathilde (Jobin) Bédard. His father's ancestors came from the parish of Saint Sulpice, Paris, France, in I666 and settled in Quebec; his mother's came from Normandy, France. He has one brother, Lucien Bédard, and eight sisters: Bernadette, Marie Louise, Caroline, Emélie, Juliette, Lucienne, Cécile and Anna-Marie Bédard.

He was prepared at the primary and commercial schools of Quebec, took the classical course at the Seminary of Quebec, where he remained until he was nineteen years of age, and in 1905 graduated from Laval University, Quebec, with the degree of B.A.

He was married July 5, 1908, in Sherbrooke, Quebec, Canada, to Miss Albertine Saint-Denis of Montreal, Canada, daughter of Felix SaintDenis and Emélie (Jobin) Saint-Denis. They have two daughters: Marcelle Bédard, born November 2, I909, and Marguerite Bédard, born December 29, I9II.

Since July, 1907, Bédard has been assistant chief forest engineer in the provincial government of Quebec. He is also professor of silviculture at the Quebec Forest School, Laval University, which position he has held since rgro. He writes: "All my practical forestry work was done in the province of Quebec on crown lands forests and in northern New Brunswick on private estates. Went to France and Switzerland during the winter of I9II to study forestry. Followed the practical works carried out in the Vosges forests (France), together with the professors and students at Nancy (Ecole des Eaux et Forêts)."

$\mathrm{He}$ is a member of the Roman Catholic church. He is a member of the Canadian Forestry Association and of the Société de Géographie de Quebec.

He has published newspaper articles on forestry and colonization in Action Sociale; reports in the Minister of Lands and Forests' annual 
reports; and articles on forests in the Bulletin de la Société Geographiqué de Quebec, in Album Souvenir and in the Canadian Forestry Association Journal.

\section{John Bentley, Jr.}

\section{Business address, New York State College of Agriculture, Cornell University, Ithaca, $N . Y$.}

John Bentley, Jr., was born June 8, I880, in Brooklyn, N. Y., the son of John Bentley and Lizzie (Annin) Bentley. On his father's side he is of English, and on his mother's of Welsh ancestry. He has two brothers: Wray A. Bentley, M.E. Columbia ' 98 , and Ellis W. Bentley; and three sisters: Nellie R. Bentley, Meta E. Bentley, B.A. Smith 'oo, and Georgia M. Bentley.

He was prepared at Adelphi Academy and the Brooklyn High School and received the degree of B.S. from Wesleyan University in 1904. $\mathrm{He}$ was a member of Psi Upsilon and Phi Beta Kappa.

$\mathrm{He}$ was married October 5, I910, in Denver, Colo., to Miss Sue Hayward of Ottawa, Ill., daughter of Hazen Hayward and Martha (McMurray) Hayward.

From July to December, 1907 , Bentley was employed in the Ritter Lumber Company of Mortimer, N. C. He served in the United States Forest Service from January, 1908, to December, I9II, and on January I, I9I2, received his present appointment as assistant professor of forestry at the New York State College of Agriculture, Cornell University.

$\mathrm{He}$ is a member of the Methodist church. At Yale he received an election to Sigma $\mathrm{Xi}$.

He has published: Pitch pine in Pennsylvania, For. Quart., r905 (compiled from statistics gathered by Forest School at Milford, Pa., 1904).

\section{Ovid M. Butler}

Business address, United States Forest Service, Ogden, Utah Home address, I24 Downey Avenue, Indianapolis, Ind.

Ovid McOuat Butler was born July I4, I880, in Indianapolis, Ind., the son of Scot Butler, formerly president of Butler College, Indianapolis, and Julia (Dunn) Butler. He is the grandson of Ovid Butler, founder of Butler College. He has four sisters: Georgia Elgin Butler, Evelyn 
Mitchell Butler, Elizabeth Ann Butler and Cordelia L. Butler, and one brother, John Scot Butler, all graduates of Butler College.

He was prepared at the Butler Preparatory School and in 1902 received the degree of B.A. from Butler College, where he was a member of Sigma Chi. In 1902-03 he worked as student assistant in the Bureau of Forestry about eight months and for two years afterward was engaged in newspaper work in Indianapolis.

He was married November 28,1908 , in Indianapolis, Ind., to Miss Adele McMaster of Indianapolis, daughter of John L. McMaster and Alpha (Steenrod) McMaster.

Butler is assistant district forester in the department of silviculture in the United States Forest Service with headquarters at Ogden, Utah. Upon entering the Service in July, 1907, he was appointed forest assistant. He afterward became deputy forest supervisor and later assistant chief of silviculture.

\section{Philip T. Coolidge}

Business address, New York State Ranger School, Wanakena, N. Y. Home address, 77 Garfield Street, Watertown, Mass.

Philip Tripp Coolidge was born December 5, 1883, in Fall River, Mass., the son of Herbert Coolidge and Phila Emma (Tripp) Coolidge. His father was active in public affairs, being a member of library, finance and town committees. He is the grandson on his father's side of John Coolidge of Watertown, Mass., and Martha (Sturtevant) Coolidge of Waterville, Maine, and on his mother's side of Azariah S. Tripp and Elizabeth R. (Griffin) Tripp, both of Fall River, Mass. He has two sisters: Delpha Coolidge, B.A. Vassar '07, and Elizabeth G. Coolidge; and one brother, Roger Coolidge.

He was prepared at the Cambridge Latin School and in 1905 received the degree of B.A. from Harvard University.

$\mathrm{He}$ is unmarried.

Coolidge is professor of forestry, in charge of the New York Ranger School, at the New York State College of Forestry, Syracuse, N. Y. From 1906 to 1909 he acted as forest assistant in the United States Forest Service, chiefly in the national forests of Colorado. In 1909-10 he was assistant professor in the Colorado School of Forestry, Colorado College, and in 1910 became professor and director of this School. This position he held until he received his present appointment in I9r2. 
$\mathrm{He}$ is a member of the Unitarian church and in politics is a Progressive. He is a member of the Society of American Foresters.

He has published: Notes on the screech owl, Auk, 1903; Silvicultural treatment of abandoned pastures in southern New England, For. Quart., I9II.

\section{Lincoln Crowell}

Business address, Office of Indian Affairs, Neopit, Wis.

Home address, 8 Monadnock Street, Dorchester, Mass.

Lincoln Crowell was born October 30,1883 , in Boston, Mass., the son of Samuel Crowell and Maria (Lincoln) Crowell. He has two brothers: Samuel Crowell, Jr., and David Crowell.

He was prepared at the Mechanic Arts High School, Boston, Mass., and in 1906 graduated from the University of Maine with the degree of B.S.

His engagement has been announced.

Crowell entered the United States Forest Service in September, 1907, as forest assistant. In March, I9I I, he became deputy forest supervisor, which position he held until April, 1912, when he was made forest examiner. In I9I 3 he was transferred from the Forest Service to the Office of Indian Affairs in the Department of the Interior as deputy supervisor of forests. $\mathrm{He}$ is at present stationed at Neopit, Wis., where he is doing general forest assistant's work on the Menominee Indian Reservation. During the winter of I9II-I2 he attended the Biltmore Forest School during its German tour.

$\mathrm{He}$ is a member of the Unitarian church. $\mathrm{He}$ is a Free and Accepted Mason.

\section{Stephen M. Crowell}

Business address, Weyerhaeuser Timber Company, Tacoma, Wash. Home address, Middletown, Conn.

Stephen Miller Crowell was born in February, 1884, in Middletown, Conn., the son of Lewis M. Crowell and Clara Whitmore (Miller) Crowell. $\mathrm{He}$ is of English ancestry. $\mathrm{He}$ has two sisters: Abbie $\mathrm{H}$. 
Crowell, D.D.S. University of Pennsylvania, and Irene W. Crowell; and one brother, Eldon L. Crowell.

In 1902 he received the degree of B.Agr. from the Connecticut Agricultural College and in 1905 the degree of B.S.

$\mathrm{He}$ is unmarried.

Crowell is in the employ of the Weyerhaeuser Timber Company, of Tacoma, Wash., locating logging railroads, mapping and timber cruising. From August 15, 1907, to September I, I908, he was with the Cleveland Cliffs Iron Company, Negaunee, Mich.; from September 5, 1908, to December 3, I909, with the Twin Falls Logging Company, Yacolt, Wash., and during February, March and April, 1912, with Fisher, Bryant \& Olmsted of Boston, Mass.

$\mathrm{He}$ is a member of the Methodist church.

\section{Samuel T. Dana}

Business address, United States Forest Service, Washington, D. C. Residence, Takoma Park, Washington, D. C.

Samuel Trask Dana was born April 21, I883, in Portland, Maine, the son of John Winchester Dana, a captain in the Civil War and for many years treasurer of the Portland \& Ogdensburg Railway, and Martha Oliver (Fessenden) Dana. On his father's side he is of French and Scotch, and on his mother's of English ancestry. He has two brothers: John F. Dana, B.A. Bowdoin College ' 98 and LL.B. Harvard Law School 'or, and Harold F. Dana, B.A. Bowdoin ' 99 and LL.B. Harvard Law School 'o2; and one sister, Helen T. Dana, B.A. Smith 'og.

He was prepared at Portland High School, Portland, Maine, and in 1904 received the degree of B.A. from Bowdoin College. He is a member of Psi Upsilon, Phi Beta Kappa and Sigma Xi. Before entering the Yale Forest School he spent a year in further study and private work at home in Portland, Maine.

He was married May 10, I9II, in Washington, D. C., to Miss Katherine Mahie Fletcher of Middlebury, Vt., daughter of Dolphin Samuel Fletcher and Clara Louise (Smith) Fletcher. Mrs. Dana died in August, rgı.

Dana has been assistant chief of silvics in the United States Forest Service with headquarters at Washington, D. C., since January I, I9I0. From July 15, I907, to December 3I, I909, he was forest assistant in the Service. Since the spring of I9I I he has been a member of the editorial advisory board 
of American Forestry. He has made one field trip to the Northeast and three field trips to various parts of the West.

$\mathrm{He}$ is a member of the Congregational church. In politics he was "previously Republican; at present Progressive." He has been treasurer of the Society of American Foresters since February, I9I0, and from February, I9II, to February, I9I2, was a member of the Committee on Admissions.

He has published: Extent and importance of the white pine blight, Circ., U. S. Forest Service, May 26, 1908; Paper birch, Silvical Leaflet 38, Oct. 20, 1908; Paper birch in the Northeast, Circ. I63, U. S. Forest Service, July 7 , 1909. He has also written book reviews and various news items for American Forestry and has done considerable work on manuscripts by other authors.

\section{Raymond Davis}

Business address, Yakima Hotel, North Yakima, Wash. Home address, 62 Bowdoin Street, Portland, Maine

Raymond Davis was born September 5, 1883, in Portland, Maine, the son of John Hobart Davis, cashier of the Casco National Bank, Portland, Maine, and Jennie E. (Constable) Davis. $\mathrm{He}$ is the grandson on his father's side of Solomon Davis and Mary Davis of Portland, Maine, and his mother's parents were William Constable and Mary Constable of St. John, N. B., Canada. He has one brother, Marshall Davis.

He was prepared at the high school in Portland, Maine, and in 1905 graduated from Bowdoin College with the degree of B.A. At college he was a member of Psi Upsilon.

He was married August 25, I909, in Portland, Maine, to Miss Avis Miriam Parker of Portland, daughter of Albert Henry Parker.

After graduating from the Yale Forest School, Davis was employed by the Cloquet Lumber Company of Cloquet, Minn., nominally as forester, but in reality to learn the lumber business. He then became cashier of the Warren Construction Company at North Yakima, laying the bitulithic pavement. $\mathrm{He}$ is at present engaged in fruit ranching in North Yakima, Wash.

He writes: "Since leaving Yale and the Cloquet Lumber Company, where I spent a little over two years, I made a trip to Florida with a view of taking over the forestry work of a large paper company at Gainesville, but did not do so. I then moved to Washington, where I have since been developing my orchard, part of the time living on the ranch and during the 
winters working in town. Was also connected for a short time with the Imperial Oil Company of Vancouver, B. C."

$\mathrm{He}$ is a member of the Unitarian church and in politics is a Progressive Republican. $\mathrm{He}$ is a member of the University Club of North Yakima.

\author{
Nils B. Eckbo \\ Business address, United States Forest Service, Ogden, Utah \\ Home address, Slemdal per Kristiania, Norway
}

Nils Bonnevie Eckbo was born February 4, 1885, in Kristiania, Norway, the son of Nils Henrik Eckbo and Martha (Jensen) Eckbo. He is a descendant of the Vikings. He has four brothers and a sister: Evind Eckbo, a graduate of Aars and Voss's College and Kristiania University, a supreme court lawyer; Axel Eckbo, a graduate of Kristiania Business College; Leo, a graduate of Hauges Minde College and a military college, now a captain in the army; Olaf, a graduate of Aars and Voss's College and the University of Berlin, now an electrical engineer; and Gunnvor Eckbo.

He was prepared at Aars and Voss's and attended Ragna Nielsen College, Norway, spent one year lumbering and then graduated from the Stenkjar Forest Academy, Norway, in 1904. Later he was engaged in lumbering in Maine and New Hampshire.

$\mathrm{He}$ is unmarried.

Eckbo has been in the United States Forest Service since July, 1907. He is now forest examiner on Uinta National Forest, with headquarters at Provo, Utah. He writes: "From July, 1907, to July, 1908, did forestry work in the Northwest and California. From July, 1908, to July, I909, studied forestry in Japan, Germany, Austria and Switzerland. From July, 1909, to July, 1912, did forestry work in various parts of District 4-in Idaho, Utah and Arizona. My experiences since leaving Yale have been in forestry lines and in the study of Mormonism, the Bible, creative evolution and down to the 'Fearsome Creatures of the Timberwoods' by Cox."

$\mathrm{He}$ is a member of the American Forestry Association.

$\mathrm{He}$ introduced the peavy or cant hook into Norway by an article in Tidsskrift for Skogbrug (a forestry professional paper) in 1904. He has also written short articles for the Forestry Quarterly and some of the lumber journals. 


\section{John H. Foster}

Durham, N. H.

John Harold Foster was born April 13, I880, in Waltham, Mass., the son of John Foster and Nellie (Webster) Foster. His father was born in Marlow, N. H., and his ancestors came from Massachusetts. His mother was born in Royalston, Mass. He has two sisters: Lena F. (Foster) Wood and Ethel D. (Foster) Muzzey.

He was prepared at the Waltham High School and received the degree of B.S. from Norwich University in 1903. In 1903-04 he was a student at the Massachusetts Institute of Technology. At college he was a member of Theta Chi and Alpha Zeta. He spent the year 1904 in a European trip and in I904-05 was an instructor in Lawrence Academy, Groton, Mass.

$\mathrm{He}$ is unmarried.

Foster is professor of forestry in the New Hampshire State College and forester of the State Agricultural Experiment Station, which positions he has held since September I, I9I I. He was at one time forest assistant in the United States Forest Service and later was assistant chief of state coöperation. $\mathrm{He}$ writes that his chief experiences in the Service consisted of work in the "Rocky Mountain region or in silvical investigations, studies of forest conditions in Alabama, Mississippi and Louisiana in separate years, woodlot and timber tract examinations over all the eastern states, examinations of forest conditions on watersheds of Allegheny and Monongahela rivers for Pittsburgh Flood commissions, and in the study of taxations of forests in New Hampshire for the State Forestry Commission."

$\mathrm{He}$ is a member of the Unitarian church. In I902-03 he was first lieutenant of the Vermont National Guard. $\mathrm{He}$ is a member of the Society of American Foresters, the American Forestry Association, the Society for the Protection of New Hampshire Forests, the Eastern Foresters Association, the Souhegan Country Club, and is a Mason. He is Secretary of the Class of 1907, Yale Forest School.

He has published: Cut over lands in Mississippi, Circ., U. S. Forest Service; Engelmann spruce in Rocky Mountains, Circ., U. S. Forest Service; Report on taxation in New Hampshire, Rep. State Forestry Com., I907-8; Report on watershed conditions, Rep. Pitts. Flood Com., I9II; Care of farm woodlots, Circ., N. H. Agric. Exp. Sta.; Forest conditions in southwestern Mississippi, Bull., Miss. State Geol. Sur. He has also written miscellaneous articles in magazines and lumber journals. 


\section{Bartle T. Harvey}

Business address, United States Bureau of Entomology, 2651/2 Fifth Street, Portland, Ore.

Home address, 46 Main Street, Orono, Maine

Bartle Trott Harvey was born November I, 1882, in Fayetteville, Ark., the son of Francis Le Roy Harvey, B.S. Iowa State College '72, M.S. ' 86 and Ph.D. '9o, and Addie Lillian (Bartle) Harvey, who did three years special work at Iowa State College. His father was professor of mathematics at Humboldt College, Iowa, in 1874, professor of chemistry and natural history at the University of Arkansas from I875 to 1885 , and professor of biology at the University of Maine from 1887 to 1900; he has written many scientific articles, discovered about fifty forms new to science in fossil plants, flowering plants, fungi, algae and insects, and there are six plant forms and one insect form named after him. He is the grandson of Daniel Harvey and Arminda (Wilkins) Harvey, daughter of William Wilkins. His mother's parents were Ransom Bartle, a descendant of Colonel Peter Bulkeley, founder of Concord, Mass., of Joseph Loomis, founder of Windsor, Conn, and the Bacons of Middletown, Conn., and Martha (Newkirk) Bartle, a descendant of the Von Nieuenkirchs of Holland and the Stuarts of Scotland. He has two brothers: Le Roy Harris Harvey, M.S. University of Maine 'or and Ph.D. University of Chicago '05, and Willis Lake Harvey, B.S. University of Maine; and two sisters: Florence Evelyn Harvey, a special student three years at the University of Maine and a graduate of the Boston Children's Hospital, and Ruth Josephine Harvey.

He was prepared at the Orono High School and in 1905 was graduated with the degree of B.S. from the University of Maine, where he also did special work in diseases of trees. At college he was a member of Phi Gamma Delta. Before entering the Yale Forest School he was engaged for some time in tree trimming and landscape gardening, worked in woods, mills, followed surveying, mapping and estimating of timber, and collected and sold insects and plants.

$\mathrm{He}$ is unmarried.

Harvey was appointed entomological assistant in the United States Bureau of Entomology, Portland, Ore., on August 28, 1912. He was at different times forester of the Great Northern Paper Company of Bangor, Maine, forest assistant in the United States Forest Service, salesman for the Cree Publishing Company, Seattle, Wash., and for the Tunnison Map Company of Chicago, Ill. He has been deputy forest fire warden, deputy forest fish and game warden and licensed guide of the State of Maine and special deputy sheriff of Multnomah County, Portland, Ore. 
He writes: "My collections were chiefly of fungi, mosses, dragon flies and spring tails. The ranges of certain species were extended and new species in fungi and spring tails were discovered. Made four expeditions on marine biological collecting trips along the coast of Maine for the state." $\mathrm{He}$ has contributed a collection of the woods of Maine, also minerals, animals, birds, insects, tree diseases, etc., to the museum of the University of Maine.

$\mathrm{He}$ is a member of the Congregational church. In politics he has no party choice, but believes in the right man for the right place. He also believes in equal suffrage. He is a representative of the United Press Syndicate and a member of the Maine Forestry Association, the American Forestry Association, the National League for Medical Freedom and the Maine State Hunters Association.

He has written articles on forestry for the Bangor (Maine) Daily Commercial and Morning Oregonian, Portland, Ore. In 1912 he made contributions to the list of dialect expressions in the annual publication of the American Dialect Society.

\section{Charles S. Judd}

Business address, 409 Beck Building, Portland, Ore.

Residence, 734 East Main Street, Portland, Ore.

Forest Service, Portland, Ore.

Charles Sheldon Judd was born July II, I881, in Honolulu, Hawaii, the son of Albert Francis Judd, LL.D., Yale '62, and Agnes Hall (Boyd) Judd. His father graduated from Harvard Law School in 1864, and was given the degree of LL.D. by Yale in I894. He also was secretary of the Constitutional Convention of the Hawaiian Kingdom in 1864, attorney general in 1873 , associate justice of the supreme court of Hawaii in 1874 , chief justice from I88I until his death in 1900 and chancellor of the Hawaiian Kingdom until it ceased to exist. $\mathrm{He}$ is the grandson of Dr. G. P. Judd, who went to Hawaii as a medical missionary in I827 and afterwards was adviser to Hawaiian kings, and a descendant of Thomas Judd, who emigrated from Kent, England, to Cambridge, Mass., in I634. His mother was the daughter of James R. Boyd, a Congregational minister in Geneva, N. Y., and also chaplain and professor at Hamilton College, principal of Maplewood Institute at Pittsfield, Mass., and head teacher at Abbott Collegiate Institute, New York City. He has two sisters, Agnes E. Judd and Sophie B. Judd, and seven 
brothers: Albert Francis Judd, Yale '97 and 'oo L.; James Robert Judd, Yale '97 and M.D. College of Physicians and Surgeons 'or; Allan W. Judd; Henry Pratt Judd, Yale 'or ; Gerrit P. Judd, D.V.S. University of Pennsylvania; and Lawrence M. Judd. A cousin, George R. Carter, graduated from the Sheffield Scientific School in 1888.

He was prepared at the Punahou School, Hawaiian Islands, and graduated from Yale College in 1905, where he was a member of the Sophomore Football Team and of the Cap and Gown Committee and received a second colloquy appointment in his Junior year. He was also a member of Alpha Delta Phi, Elihu Club and Sigma Xi.

He was married June II, I9I0, in New Haven, Conn., to Miss Louise Luquiens of New Haven, daughter of Professor Jules Luquiens, Ph.D. Yale 1873, head of the French department at Yale (died August 23, 1899), and Emma (Clark) Luquiens. She has two brothers: Huc-Mazelet Luquiens, Yale '02, and Frederick Bliss Luquiens, Yale '97.

During the summer of 1906 Judd returned to Honolulu after a five years' absence. He worked for the Board of Commissioners of Agriculture and Forestry of the Territory of Hawaii for seven weeks in Honolulu and on the island of Kauai, taking measurements of growth and volume in six hundred acres of planted forest trees. He writes: "Immediately upon graduation from the School I entered the Forest Service as forest assistant in management and started west with my assistant chief, stopping off at the Medicine Bow Forest, Wyoming. In California we visited the Diamond Mountain and Plumas forests, attended the Irrigation Congress at Sacramento, and visited the Shasta Forest. I was then stationed on the Diamond Mountain from September, 1907, to April, I908, where I was engaged in the administration of two large timber sales, marking western yellow pine for cutting, and scaling logs. I also surveyed ranger stations and claims and, after the snow came, drew maps in the supervisor's office. In April, 1908, I was called into the Washington office, where during a long hot summer I became thoroughly imbued with the timber sale policy and procedure of the Forest Service. At the time of the redistricting in December, 1908, I was promoted and assigned to the district office at Portland, Ore, as assistant chief of silviculture. During the summer of 1909 I inspected the Snoqualmie National Forest, Washington, covering a large area of forested mountains in the Cascades east of Seattle. In thirty days I traveled on foot 340 miles, visiting all of the operations on the forest and often alone, but more 
often with a ranger, slept out under a giant hemlock or huge Douglas fir overnight and lived for the most part on trout and wild blackberries. In October, 1909, I went to Los Angeles with my mother and was best man at the wedding of my brother Henry. In December of the same year I estimated timber on snowshoes on the Whitman Forest in eastern Oregon. In the spring of r9Io I inspected timber sales and seed sowing operations on the Oregon National Forest near Mt. Hood.

"In May, I9I0, I went east to New Haven, Conn., where I was married on June II. On the honeymoon trip west we stopped off at Salem, Ohio, and Cashmere, Wash., visiting relatives, before returning to Portland. During August, I9Io, while the forest fires were at their worst, visited most of the National forests in Washington in a seed collecting campaign. In the fall of the same year inspected seed sowing operations on the Olympic, Columbia, and Oregon forests. In February, I9II, lectured on timber sales at the Ranger School of the University of Washington at Seattle. While inspecting timber sales on the Colville Forest in northeastern Washington in June, I9I I, received the offer of a position in Honolulu from the Governor of Hawaii. On July 25, I9r r, entered upon the duties of commissioner of public lands and president and executive officer of the Board of Commissioners of Agriculture and Forestry, Territory of Hawaii.

"During September, I9II, made the circuit of the Island of Hawaii on an official automobile trip with the Governor and Attorney General of the Territory and on the way back to Honolulu stopped off for some goat hunting on the almost uninhabited desert island of Kahoolawe. As president of the Board of Agriculture and Forestry, began a campaign for the control of a serious infestation of the Mediterranean fruit fly and was instrumental in passing a dog quarantine regulation to prevent rabies from getting to the Islands.

"Returned to Portland, Ore., during March, I9I2, and resumed duties with the Forest Service as assistant district forester, District 6."

He was a messenger in the Citizens' Guard of Hawaii during the revolution of 1905 and a trooper in the Mounted Reserves, Republic of Hawaii, at the time of annexation to the United 
States in 1908 , and served in the same capacity as a quarantine guard at Makapuu Pass, Oahu, for two months in I90o during the epidemic of bubonic plague.

Judd is a member of the Central Union Church (Congregational) of Honolulu. He is a Republican, and is a member of the Society of American Foresters, the Concatenated Order of Hoo-Hoo, the Oregon Conservation Association and the University Club of Honolulu.

He has published: The sandalwood tree in Hawaii, For. and Irr., April, 1905; Summer session of the Yale Forest School, For. and Irr., March, 1906; Seed distribution in Hawaii, Haw'n Agric. and Forester, Jan., I907; A mesquite grove in Hawaii, For. and Irr., April, I907; Efficacy of goats in clearing brush lands in the Northwest, Proc. Soc. Am. Foresters, VI, No. I, I9II; Western red cedar, The Timberman, Portland, Ore., Oct., 1910; Portland needs an arboretum-Open letter to the Oregon Daily Journal, Portland, Ore., April 19, I9II; Two minor wood industries, For. Quart., X, No. 2, 1912.

\section{Francis B. Kellogg}

Business address, United States Forest Service, Beck Building, Portland, Ore.

\section{Home address, 98 El Camino Real, Berkeley, Calif.}

Francis Bentley Kellogg was born August 28, 1879, in Anaheim, Calif., the son of George Herbert Kellogg, B.A. Kenyon College '68, and Fay (Chase) Kellogg. He is the grandson of Rev. Ezra B. Kellogg, D.D., who served in the War of 1812 , and Anna (Thompson) Kellogg, and the great-grandson of Jason Kellogg. On his mother's side he is the grandson of Rev. Dudley Chase, U. S. A., appointed chaplain in the regular army by Lincoln, and Sarah Griffeth (Wells) Chase, and the great-grandson of the Rt. Rev. Philander Chase, Episcopal bishop of Ohio and Illinois and founder of Kenyon College, and Hon. Bezaleel Wells, founder of Canton, Wellsville and Steubenville, Ohio. $\mathrm{He}$ has one sister, Grace Wells Kellogg.

$\mathrm{He}$ was prepared at the Lowell High School and Boone's University Academy and in 1905 graduated from the University of California with the degree of B.S. He was a member of Sigma Alpha Epsilon and Skull and Keys.

$\mathrm{He}$ is unmarried.

Kellogg entered the United States Forest Service July I, I907, as forest assistant on the Sierra South National Forest, Califor- 
nia, and later was transferred to the Rainier Forest, Washington. He then became timber cruiser for the Department of the Interior, Oregon. He again was appointed forest assistant in timber sales, District 6, and after this deputy forest supervisor of Cascade National Forest, Oregon. $\mathrm{He}$ is at present forest assistant with headquarters in Portland, Ore.

$\mathrm{He}$ is a Progressive. $\mathrm{He}$ is a member of the University Club of Portland, Ore., and the Concatenated Order of Hoo-Hoo.

He has published: The Problem of the dune, Calif. Jrl. Tech., 1904 .

\section{Kingsley R. MacGuffey \\ Parkdale, Ore.}

Kingsley Rich MacGuffey was born January 5, I880, in Cincinnati, Ohio, the son of Alexander Hamilton MacGuffey, LL.D., a lawyer of the firm of MacGuffey, Morrell \& Strunk, and Caroline Virginia (Rich) MacGuffey, a niece of Maria Mitchell, professor of astronomy at Vassar College, and a descendant of John Rich, first Earl of Warwick, England. His father is a non-graduate of Miami University, having been a student there in 1832 and was dean of the Cincinnati College of Law. On his father's side he is of Scotch and on his mother's of American descent. He had three brothers: Telford, Winthrop, C.E. Harvard '95, and Harold, all deceased; and two sisters: Agnes (deceased) and Margaret, who graduated from the Albany State Library School in 1896. An uncle, Frederick Packard, graduated from Yale in 1848.

He was prepared at the Taft School, Watertown, Conn., and graduated from Yale in 1905, where he was Dwight Hall organist and a member of the Boys' Club Committee.

$\mathrm{He}$ is unmarried.

MacGuffey is president of the Red Cross Orchard Company of Parkdale, Ore. In addition to managing his ranch there, he is' also in the employ of the Pacific Telephone \& Telegraph Company of San Francisco. He entered their traffic department in February, 1913.

Immediately after graduation from the Forest School in I907, he entered the United States Forest Service, spending the months of July and August making a study of hickory in Tennessee, and from then until November he was stationed in Washington, D. C. From there he was sent to Missoula, Mont., as forest assistant. He held this position until June, 1908, when he was 
given a furlough, and in company with Nils B. Eckbo, M.F. 'o7, took a trip around the world, visiting Japan, China, Siberia and the principal European countries. In January, 1909, he returned to this country and reëntered the Forest Service, remaining until June, 1909, when he resigned. He spent the summer in England, returning in December of this same year. In company with Russell Gordon Pond, of the Class of 1906, Biltmore Forest School, he took up the business of fruit-growing, incorporating the Red Cross Apple Company, of which he is president.

MacGuffey is a member of the Protestant Episcopal church, the Independent Order of Odd Fellows and the Commercial and University clubs of Hood River and the Upper Hood River Progressive Association.

\section{Clyde S. Martin}

Business address, Elma Camp, No. I, Saginaw Timber Company, Aberdeen, Wash.

Residence, 304 West Third Street, Aberdeen, Wash.

Clyde Sayers Martin was born September 19, 1884, in Waynesburg, $\mathrm{Pa}$, the son of Charles Alexander Martin, one of the first teachers in the Calcutta Boys School, India, and Florence Adelaide (Sayers) Martin. $\mathrm{He}$ is of Scotch-English ancestry. He has one brother, Edwin Ezra Martin.

He received the degree of B.S. in 1905 from De Pauw University, where he was a member of Beta Theta Pi.

$\mathrm{He}$ was married June 30 , 1909, in Rushville, Ill., to Miss Florence Alexander Roach of Rushville, daughter of Herschel B. Roach and Helen (Chadsey) Roach. They have one son, Charles Alexander Martin, born May 9, I910, in Aberdeen, Wash.

From 1907 to 1912 Martin was with the Weyerhaeuser Timber Company, where he acted as fire warden, inspector, compassman, timekeeper, logging engineer, trespass man and topographer. Since July 10, 1912, he has held the position of logging engineer with the Saginaw Timber Company.

He writes: "My work here has grown entirely apart from forestry as a profession in itself. It is rather logging engineering in its broader sense; going on the theory that after all is said and done logging is a problem of transportation primarily. In this country of large timber our operations have developed 
on such a large scale that the larger companies have found pressing need for a systematization of methods and accounting. A technically trained man working from a basis of thorough understanding of present methods and conditions is preëminently the man for this work. It takes years of hard preparatory work under actual logging conditions to fit a man for such a position, but the future promises great things for the man who will persevere until he is a recognized authority on scientific logging. And it is the forester working from the inside, with a full knowledge of actual conditions who can best say to what extent forestry may be practiced by the logger. Briefly, these are the lines upon which I am working and by which I hope to show that there is a field for the technical man in private work."

$\mathrm{He}$ is a member of the Methodist church and in politics is a Progressive Republican. $\mathrm{He}$ is a member of the Concatenated Order of Hoo-Hoo.

\section{David T. Mason}

United States Forest Service, Missoula, Mont.

David Townsend Mason was born March II, I883, in Newark, N. J., the son of William B. R. Mason, postmaster of Bound Brook, N. J., a newspaper publisher, manager of a water company and president of the Building Loan Association, and Rachel Manning (Townsend) Mason. $\mathrm{He}$ is a descendant on his father's side of Captain John Mason, who with two brothers settled in Massachusetts in I634. One of these brothers operated the first sawmill in New England, on the Piscataquis River in Maine. His mother's ancestors came to New Jersey in colonial times, some of them having land of royal grant, part of which is still in the family. He has two brothers: Fred R. Mason, B.S. Rutgers '05 and M.F. Yale 'ri, and H. F. R. Mason.

He was prepared at the Plainfield (N. J.) High School and received the degree of B.S. from Rutgers College in 1905 and in 1908 the degree of M.S. At college he was a member of Phi Beta Kappa and Chi Psi.

He was married October 4, I9II, in Missoula, Mont., to Miss Georgia Evelyn Polleys of Missoula, Mont., daughter of Edward H. Polleys and Edna (Woodcock) Polleys.

Since graduating from the Yale Forest School, Mason has been employed in the United States Forest Service, where he has held the following positions: forest assistant, Montezuma National Forest, Colorado, and Washington, D. C., July I, I907, 
to June 30,1908 ; assistant chief of timber sales, Washington, D. C., July I, I908, to November 30, I908; assistant chief of silviculture, District I, Missoula, Mont., December I, I908, to July I, I909; assistant district forester, District I, Missoula, Mont., July I, 1909, to July I, I910; forest supervisor, Deerlodge National Forest, Montana, July I, I9IO, to July I, I9I2; and assistant district forester, District I, Missoula, Mont., July I, I912, to the present time. In January, February and March of I9II and I9I2 he was detailed to give work in connection with short courses in forestry at the University of Montana. He has in preparation a bulletin on the lodgepole pine in which many new and interesting facts are set forth.

In politics he is a "Progressive-Independent." $\mathrm{He}$ is a member of the Society of American Foresters and the Concatenated Order of Hoo-Hoo.

\section{Louis S. Murphy}

Business address, United States Forest Service, Washington, D. C. Home address, 4 Thurston Street, Winter Hill Station, Boston, Mass.

Louis Sutliffe Murphy was born August Io, 1876, in Boston, Mass., the son of Joseph Henry Murphy and Elizabeth Marion (Atkins) Murphy. He is the grandson on his father's side of Michael Thomas Murphy, born in Ireland in 1797, and Eleanor Jane (O'Neal) Murphy, born in Canterbury, England, in 1806, who were married in Halifax, N. S., Canada, in 1831. His mother's foster parents were Sophronia Elizabeth Atkins and Caleb Upham Atkins.

He was prepared at the Forster Grammar School, Somerville, Mass., and at the Boston English High School and from July, 1895, to September, 1897 , was a clerk in the insurance office of O'Brion \& Russell, Boston. In I90I he received the degree of B.S. from Tufts College, where he was a member of Delta Tau Delta. From Igor to 1905 he was employed as chemist in the North Packing \& Provision Company of Somerville, Mass.

$\mathrm{He}$ is unmarried.

Murphy has been a forest examiner in the United States Forest Service since January, I9I0. He was forest assistant from July, 1907, to January, 19I0. From November, I9II, to May, I9I2, he was in Porto Rico studying its forest problems and formulating a forest policy for the Island as a whole and for Luquillo National Forest. 
He writes: "Porto Rico presents unusual interest for the forester just now, for, unless all signs fail, both the Forest Service and the Government of Porto Rico will soon need one or more trained foresters to direct the forestry operations which each seems destined to institute in the near future. Conditions in Porto Rico are ripe for the practice of intensive forestry from the start. Formerly well timbered, the Island is now only sparsely wooded. Not only have its inhabitants,-now numbering $1,116,000$ or 325 persons per square mile,-drawn freely upon this resource in the past, and even destroyed it to make way for agriculture and cattle raising, but considerable timber has also been exported.

"A dense population, geographic isolation, short hauling distances, a productive soil, a year round growing season, and an abundant native tree flora, not to mention exotics, constitute the materials at hand. The forest fire menace is negligible and frosts are unknown, although excessive precipitation, the tradewinds, and an occasional hurricane will have to be given consideration. The production of cabinet woods for export will have no place in Porto Rican forestry, since local consumption will take care of all that the lands available for forestry will produce. Wood for fuel is most urgently needed, also for posts and house piling, structural materials for native use, and for boxes and crates for the shipment abroad of the fruit and other products of the Island.

"Altogether the working out of a successful forest policy to meet these various needs, as well as the demands for a protective cover to aid in the control of erosion, for shade along roads and in cattle pastures, and the like, holds out alluring possibilities for those who would enter a pioneer field."

He attends the Unitarian church and in politics is a Republican. From December, I902, to June, I905, he served as private in Troop A (National Lancers), ist Battalion Cavalry, Massachusetts Volunteer Militia. At Yale he received an election to Sigma Xi. He is a member of the American Forestry Association and the Society of American Foresters, is a Mason and belongs to the Somerville Lodge, 917, Benevolent and Protective Order of Elks. 


\section{Gustave C. Piché}

Business address, Care of the Department of Lands and Forests, Quebec, Canada

Residence, 64 St. Cyrille Street, Quebec, Canada

Gustave Clodomir Piché was born December 2, 1880, in Montreal, Quebec, Canada, the son of Clodomir Piché (died in 1882), and Marie (Heppel) Piché. His father was a descendant of the first French settlers that arrived in Canada about 1663 . His mother was married a second time, in 1887 , to D. Villeneuve of Berthierville, Quebec. Her ancestor, Pierre Heppel, who came to Quebec in 1792 , was a surgeon in Lafayette's army. He has a step-sister, Eva (Villeneuve) Piette, of Berthierville.

He graduated from Mount Saint Louis in 1897 , after which he was employed three years as a clerk on the Canadian Pacific Railway and then in the Belgo-Canadian Company, where he was in charge of the wood department from 1900 to 1903 . From 1903 to 1905 he attended the Polytechnical School of Montreal.

He was married September 24, 1907, in Montreal, Quebec, to Miss Césarine P. Paré of Montreal, daughter of Cyrille Paré and Dorimène Le Noblet (Duplessis) Paré. They have four daughters: Claudette Piché, born June 15, 1908, in Berthierville, Quebec; Simone Piché, born August 21, 1909, in Quebec; Pierrette Piché, born December 12, 1910, in Quebec, and Marie-Paule Piché, born May 31, 1912, in Quebec.

In 1907, Piché entered the Forest Service in Quebec as forestry engineer and in 1909 became chief forestry engineer. In I9IO, he received the appointments of chief of the Forest Service and director of the Ecole Forestière of Quebec, his present positions. He writes: "Visited France, Italy, Germany and Sweden in 1909-IO, on the account of the Quebec government. In 1908, worked at the inventory of the Riding Mountain Forest Reserve in Manitoba. Since 1907, I have visited every section of the Province to investigate the forest and agricultural conditions. These reports are filed in the Department of Lands and Forests."

$\mathrm{He}$ is a member of the Roman Catholic Church. He is a member of the American and Canadian Forestry associations, the Canadian Society of Forestry Engineers, the French, Belgian and Swiss societies of forestry, the Alliance Nationale (a benevolent society) and in 1913 was elected an associate member of the Canadian Society of Civil Engineers. 


\section{Colin C. Robertson}

Care of Forest Department, Pretoria, South Africa

Colin Charles Robertson was born November I, 1884, in Haileybury College, Hertfordshire, England, the son of James Robertson (died in 1903), a clergyman in the Church of England, master at Rugby and Harrow Schools and headmaster of Haileybury College, and Constance Elizabeth (Wilson) Robertson. On his father's side he is of Scotch, and on his mother's of English ancestry. He has three brothers: A. J. Robertson, M.A. Cambridge University; M. Robertson, M.A. Oxford University; and D. H. Robertson, B.A. Cambridge University; and two sisters: S. M. Robertson and G. C. Robertson.

He attended the Rugby School in 1902, and from February, 1903, to June, 1905, was a member of the Forestry Department in Orange Free State, South Africa.

$\mathrm{He}$ is unmarried.

From October, 1907, to March, 1912, Robertson was assistant conservator of forests in Orange Free State, and since April, I9I2, when the various forest departments in South Africa were reorganized into one Forest Department, he has held the position of research officer at the office of the chief conservator of forests, Pretoria, South Africa.

$\mathrm{He}$ is a member of the Church of England. He is a member of the South African Association for the Advancement of Science, of which he was a member of the Council in I911-12, the Philosophic Society of Orange Free State, of which he was secretary in I9II-I2, the Royal Colonial Institute and the Old Rugbeian Society.

He has published: Farm forestry in Orange Free State, Bull. Forest Department, South Africa; Some suggestions as to principles of the introduction of exotic forest trees, Jrl. S. African $A s s^{\prime} n$ for $A d v$. of $S c$.

\section{David N. Rogers \\ Quincy, Calif.}

David N. Rogers was born April 7, I882, in Patten, Maine, the son of Luther B. Rogers and Mary E. (Barker) Rogers. He has three brothers: Edwin S. Rogers, Lore Alford Rogers, B.S. University of Maine ' 96 , and graduate student at the University of Wisconsin, and 
Luther B. Rogers, Jr., C.E. University of Maine; and three sisters: Mary H. Rogers, Annie L. Rogers and Ruth Rogers.

He was prepared at Patten Academy, Patten, Maine, and in 1906 received the degree of B.S. from the University of Maine, where he was a member of Kappa Sigma.

He was married October 30, 1912, in Quincy, Calif., to Miss Edith Watson of Quincy, daughter of William and Mary Frances Watson.

Rogers is forest supervisor in the United States Forest Service with headquarters in the Plumas National Forest, California. He was appointed forest assistant in the Service July I, I907, and later became deputy forest supervisor.

In politics he is a Progressive.

\section{Robert Rosenbluth}

Business address, Conservation Commission, Albany, N. Y. Home address, 522 West I5oth Street, New York City

Robert Rosenbluth was born February 28, 1887, in New York City, the son of Selig Rosenbluth, superintendent of a large hospital, and Anna (Glantz) Rosenbluth. He is of Russian German ancestry on both sides of the family.

In 1903 he graduated from Philadelphia High, after which he studied as a "special in agriculture" at Pennsylvania State College. He afterward attended the Forest Academy at Mount Alto, $\mathrm{Pa}$.

$\mathrm{He}$ is unmarried.

Rosenbluth was employed as forest assistant in the United States Forest Service in 1907 and in the same year became forester in the Bureau of Forestry with headquarters in the Philippine Islands. In I9IO-I I he was forest assistant in the Service and in I9II-I2 was state forester for the Conservation Commission of New York State. Since July 8, I912, he has held the position of director of forest investigations for the Conservation Commission of New York State.

He writes: "Travel since leaving Yale has embraced practically all the states in this country; Hawaii; the Philippine Islands; China and Japan. Most interesting was the work in the Philippines, not only in exploration of new countries and under conditions entirely different from those at home, but in the scientific and practical value of the results. There was 
enough excitement incidental to these explorations to satisfy one for the time. In China and Japan I got an insight into these great civilizations and the currents of interest. Especially interesting was an extended trip in those parts of China where the revolution was at its height but a short time later. In District 4, I did extensive work along the Grand Canyon of the Colorado and also in the desert regions of Nevada. Since then, have been on the intensive problems of New York State."

Concerning politics, Rosenbluth writes: "Am a Democratprogressive, with strong leanings toward Socialism; believe, however, that the Democratic party is a more efficient means towards that end than is the present Socialist party." $\mathrm{He}$ is a member of the Y. M. C. A.

He has written: Forestry for China, Nat. Rev., Shanghai; Forestry for farm and county estates, Bull. Conservation Com. $\mathrm{He}$ is preparing an article on Lumber trade of the Chinese Empire, to be printed in the Forestry Quarterly.

\section{Alfred Senn}

Business address, Care Board of Park Commissioners, Milwankee, Wis.

Alfred Senn was born October 23, I859, in Bennwye, Basel Land (canton), Switzerland, the son of J. J. Senn, son of Hans Jacob Senn, and Salome (Heinemann) Senn, daughter of Jeremias Heinemann.

He was graduated at the Swiss French College in I88I and before entering the Yale Forest School was engaged in the lumber business in Switzerland.

He was married a second time May I8, 1905, in Sheboygan, Wis, to Miss Lena Hildebrandt of Sheboygan, daughter of Frederic Hildebrandt. He has one son, Alfred Senn, born August 8, 1898.

Senn was at one time planting agent in the United States Forest Service and later acted as forester for a private party in the northern part of Wisconsin. Since January $\mathrm{x}$, I9II, he has been park forester for the Board of Park Commissioners of Milwaukee, Wis.

$\mathrm{He}$ is a Mason and has served in the Swiss army.

$\mathrm{He}$ has delivered lectures before different societies in Milwaukee and before the Wisconsin State Horticultural Society at Madison, Wis. 


\title{
William C. Shepard
}

\author{
R. F. D. 59, Berlin, Conn.
}

William Chambers Shepard was born March 29, 1883, in Ogdensburg, N. Y., the son of Leonard Griffin Shepard, chief of the United States Revenue Cutter Service, and Isabel (Sharpe) Shepard. He has one brother, Leonard Griffin Shepard, M.E. Cornell 'o3.

$\mathrm{He}$ was prepared at the high schools in Washington, D. C., and in I90I entered the Cornell Forestry School, leaving in 1903 when the School was discontinued. He was a member of Delta Upsilon Fraternity. Before entering the Yale Forest School, he worked two years with a lumber company in West Virginia. He received the degree of F.E. at Cornell in 1907 .

He was married October 7, 1909, in Berlin, Conn., to Miss Katrina Sloat Bowers of Bridgeport, Conn., daughter of Dr. William C. Bowers, Yale '74. They have one son, William Bowers Shepard, born September 27, I910, in Berlin, Conn., and one daughter, Katrina Sloat Shepard, born October 8, 1912, in Berlin, Conn.

Shepard was employed as forest assistant by the Pennsylvania Railroad Company from May I5, 1907, to November I, I909, when he became assistant forester for the same company. He has lately resigned from this position and is managing a prosperous farm in Berlin, Conn.

$\mathrm{He}$ is a member of the Presbyterian church and belongs to the Society of American Foresters.

\section{Charles P. Wilber}

Business address, Forest Commission, State House, Trenton, N. J.

Home address, Bishop Place, New Brunswick, N. J.

Charles Parker Wilber was born October 23, 1882, in New Brunswick, N. J., the son of Francis Augustus Wilber, professor at Rutgers College, New Jersey, and Laura Burge (Parker) Wilber. He is of English and Scotch ancestry. He has one brother, F. E. Wilber, B.D. New Brunswick Theological Seminary, and one sister, L. E. Wilber, B.A. Smith College.

He was prepared at the Rutgers Preparatory School and received the degrees of B.A. in 1905 and M.A. in 1908 from Rutgers College, where he was a member of Chi Psi.

$\mathrm{He}$ is unmarried. 
Wilber was employed with the William M. Ritter Lumber Company of West Virginia from June, I907, to January, I908, when he became forest assistant in District 4 of the United States Forest Service. Since July, I9I0, he has held the position of New Jersey state fire warden for the New Jersey Forest Commission.

He writes: "Nearly two million acres of forest, largely within reach of densely populated centers, traversed by an unusual mileage of good roads, criss-crossed by a thousand miles of railroad, and in large part without the telephone, present in New Jersey a field of work in forest protection in which a strong foundation has been laid, but which still offers a wide scope for work on the superstructure.

"Control of this situation now rests on a state fire warden with four helpers, 275 local men under a township warden system, and a small corps of fire lookouts and patrolmen. Though it has its weaknesses, experience has proved that the local system can eventually be relied on. The public understands the fight on fire because it sees results and the local effort producing them. The short step from forest protection to forest development is taken by yearly increasing numbers. An annual retainer of $\$ 10$ to $\$ 20$ to the wardens, with reasonable but not attractive pay to them and all fighters at a fire, elicits creditable activity and ready response whenever need arises. A strict requirement of permits for all brush burning throughout the year but latitude in handling individual situations by special annual permits has engendered universal caution without causing excessive inconvenience. Rigid imposition of some penalty for every violation of the law, but the possibility of a reasonable adjustment of its severity to the specific case, have made supporters instead of enemies of most offenders.

"High efficiency comes slowly, but the fires are growing smaller and their aggregate area less. Carelessness is giving way to caution. Offenders punished now number hundreds yearly. The woodlands, so repeatedly burned heretofore and long rated of little value, are showing the effect of fire control, for forests are spontaneous throughout the state and their recuperative powers prodigious. New Jersey, therefore, stands committed to a policy of establishing forest values, existent and potential, by guaranteed protection from fire." 
$\mathrm{He}$ is a member of the Dutch Reformed church. $\mathrm{He}$ is a member of the Society of American Foresters, the Eastern States Forestry Association, the National Geographic Society and the Concatenated Order of Hoo-Hoo.

\section{Hugo Winkenwerder}

Business address, University of Washington, Seattle, Wash. Residence, 6306 Seventeenth Street, N. E., Seattle, Wash. 405 North Washington Street, Watertown, Wis.

Hugo [August] Winkenwerder was born March 16, 1878, in Watertown, Wis.

He prepared at Northwestern University, Watertown, Wis., and graduated from the University of Wisconsin in 1902 with the degree of B.S. and taught botany and physiography in the high school in Sheboygan, Wis.

He was married to Miss Adelene Maddern Clark of Los Angeles, Calif.

Winkenwerder is dean of the College of Forestry at the University of Washington, which position he has held since August I, I9I2. He was at one time forest assistant in the United States Forest Service and later became assistant professor of forestry at Colorado College. His first appointment at the University of Washington was as associate professor of forestry.

$\mathrm{He}$ is a member of Sigma Xi.

He has published: The migration of birds-monographs, Wis. Nat. Hist. Soc., Milwaukee, 1902; Forestry in the public schools, Circ. 130, U. S. Forest Service; Progress in conservation, Proc. N. E. A., Chicago, I908; Short keys to trees of Oregon and Washington, Forest Lab., Univ. of Wash., 1910; Outline for correlation of methods in forest mensuration, Forest Lab., Univ. of Wash., I909; Forests and American history, Univ. of Calif. Chronicle, Berkeley, 1912.

\section{*Edward S. Woodruff}

\section{Died I909}

Edward Seymour Woodruff was born December 23, 1876, in New York City, the son of Charles Hornblower Woodruff, Yale '58, and Catherine G. (Sanford) Woodruff. He was a grandson of Hon. Lewis Bartholomew Woodruff, LL.D., Yale '30, judge of the United States Circuit Court, and a great grandson of Chief Justice Joseph C. Hornblower of New Jersey. 
He was a nephew of Col. George B. Sanford, Yale '63. He had three brothers: Lewis B. Woodruff, Yale ' 90 , Frederick S. Woodruff, Yale ' 92 , and Charles H. Woodruff, Jr., ex-' 96 (died in February, 1909).

$\mathrm{He}$ was prepared at Phillips (Andover) Academy, of whose New York Alumni Association his father was the first president, and in 1899 graduated from Yale College. He then spent a year in biological study in the Graduate Department of Johns Hopkins University, followed by a short period with an investment firm in New York City. In his Senior year at the Yale Forest School he was president of his Class, was elected to Sigma Xi and, upon graduating, was appointed a member of the Graduate Advisory Board.

He was unmarried.

In the summer of 1907 Woodruff became a state forester of New York. In this position he gave his attention chiefly to reforestation in the Adirondack Mountains. He was deeply interested in research work in botany, entomology and ornithology, of which he gained much knowledge in the country about Litchfield, Conn.

He died January 15, 1909, in New York City of typhoid fever and was buried in Litchfield, Conn., where he had spent a large part of his life.

His published work was principally upon birds, and included Summer birds of Milford, Pike County, Pa., in Cassinia Bird Manual, 1905; A preliminary list of the birds of Shannon and Carter Counties, Missouri, The Auk, April, I908; and Scarcity of the ruffed grouse, 13th Annual Report of the Forest, Fish, and Game Commission of New York; also a paper (published in this report) on "Destruction of white and Scotch pine seedlings by the white grub."

\section{Graduate holding Certificate but not Degree}

\section{William Winter}

Business address, 1003 Majestic Building, Indianapolis, Ind. Residence, I329 North Meridian Street, Indianapolis, Ind.

William Winter was born March I4, I88I, in Indianapolis, Ind., the son of Ferdinand Winter and Mary (Keyes) Winter. He has two brothers: Clarence Winter, B.A. Yale '97, and Keyes Winter, B.A. Yale 'oo; and three sisters: Sue, Katherine and Mary Winter.

He was prepared at St. Paul's School, Concord, N. H., and at the Hotchkiss School, Lakeville, Conn., and in I899-I900 attended the Massa- 
chusetts Institute of Technology, where he was a member of Delta Kappa Epsilon.

His engagement has been announced.

Winter is an attorney-at-law in the firm of Winter \& Hendricks. In 1907 he was foreman for the Gulf Lumber Company, Louisiana, and in 1907-08 was employed with the International Paper Company of Palmer Falls, N. Y. He entered the United States Forest Service in I908 as land examiner and later became forest assistant. In I9Io he was appointed civil engineer in the firm of Albright \& Mebus, Philadelphia, Pa., which position he held until I9II, when he went into his father's office as attorney. He became a partner of the firm in February, I9I2.

\section{Non Graduates}

\section{J. Franklin Bruins \\ Box 249, Pocitello, Idaho}

John Franklin Bruins was born July 24, 1883, in Brandon, Wis., the son of Derk Bruins, a successful farmer (now retired), and Cristina (Heusinknelt) Bruins. His father was a prominent citizen and church worker in the farming community where he lived. His ancestors on his father's side were Dutch farmers, his grandfather having come from the Netherlands to America as an immigrant in 1847. His mother is the descendant of a Dutch family, her parents having come to this country from the Netherlands in 1850 . He has three brothers: William $\mathrm{H}$. Bruins, a graduate of Hope College and McCormick Theological Seminary, Henry M. Bruins, a graduate of Hope College and B.A. Princeton ' 96 , and Dirk Bruins, B.A. Ripon College and M.D. Northwestern University; and a sister, Minnie $H$. Bruins, who attended the University of Wisconsin.

He was brought up on a farm, working there during his vacations. He attended Ripon College, where he was a newspaper correspondent and manager of the college paper, and in 1905 graduated from Beloit College with the degree of B.A.

He was married July 12, I91 I, in Madison, Wis., to Miss Rose Wagner of Menasha, Wis., daughter of Henry Wagner.

Since October I, I9IO, Bruins has been forest supervisor in the United States Forest Service with headquarters at Pocatello, Idaho. From 1906 to 1908 he was forest assistant in the Service and from 1908 to rgIo held the position of deputy forest supervisor. 
He writes: "As a forest assistant I was one of the second batch to be sent to the National forests. I was first assigned to the Old Henry's Lake in Idaho. I was there principally concerned with timber sale work and secured some figures on the workings of the log scale in use in the Service which I am told has been of much value. The following summer I spent in the Washington office of the Service as district forester. Was shortly afterward sent to the Leadville National Forest in Colorado, where I remained about a year and a half doing principally administrative work. In the spring of 1909 I was transferred to the Targhee as deputy supervisor, work altogether administrative, and that fall was placed in charge of the Pocatello Forest, where I have been since. My principal interest from a professional standpoint is in forestation problems. Since I have been on this forest I have had a chance to engage in that line on an extensive scale with some degree of success, but with results still mainly undetermined."

$\mathrm{He}$ is affiliated with the Congregational church. $\mathrm{He}$ is a member of the Society of American Foresters and of the Y. M. C. A.

\section{Harrison DeW. Burrall}

Business and home address, Porvenir, San Miguel County, N. Mex. United States Forest Service, Albuquexque, N. Mex.

Harrison DeWitt Burrall was born May 21, 1883, in Battle Creek, Mich., the son of George Burrall, a wholesale hardware merchant, and Fannie Grace (Beecher) Burrall. On his father's side he is of Irish, and on his mother's of English ancestry. He has a brother, Frederick P. Burrall, M.E. Michigan Mining School, and a sister, Grace F. Burrall, B.S. London Ontario College.

He was prepared at Lawrenceville School and at Biltmore, N. C., spending his summers as a compass man, etc., working on timber estimates.

He was married July 3, 1907, in Fort Smith, Ark., to Miss Sarah Fairfax Musser of Germantown, Md, daughter of William Henderson Musser and Mary Jett (Fairfax) Musser. They have one daughter, Mary Beecher Burrall, born in March, 1908, in Douglas, Ariz., and one son, Harrison Walker Burrall, born in January, 1909, in Washington, D. C. Another son, Frederick Beecher Burrall, born in January, I9Io, in Fort Smith, Ark., died in September, I9Ir. 
Burrall is forest examiner in the United States Forest Service, in charge of Las Gallinas Nursery, Pecos National Forest, New Mexico. Previous to this he was forest assistant in the Service.

$\mathrm{He}$ is a member of the Christian Science Church of Boston, Mass. In politics he is a Republican, believing in Roosevelt principles. He is a member of the National Geographic Society and of the Concatenated Order of Hoo-Hoo.

\section{Charles H. Flory}

Business address, United States Forest Service, Portland, Ore.

Residence, 85 East Eighty-seventh Street, North, Portland, Ore.

Charles Henry Flory was born June 24, I880, in Arcanum, Ohio, the son of Albert M. Flory and Katherine Elizabeth (Burns) Flory. He has three sisters: Blanch Flory, Imo Flory and Leola Flory.

He was prepared at the high school in Arcanum, Ohio, and in 1905 received the degree of B.S. from Ohio State University.

He was married July I9, 1906, in Denver, Colo., to Miss Emma Clara Bernsdorf of Stralsund, Pomerania, Germany, daughter of Marie Amelia Bernsdorf and Karl Bernsdorf. They have a son, Albert Bernsdorf Flory, born August 12, 1908, in Bellingham, Wash.

From July 2, 1906, to February I, 1908, Flory was forest assistant in the United States Forest Service. He then became forest supervisor, which position he held until December I, I908, when he became assistant district forester in charge of operation in District 6, his present appointment.

$\mathrm{He}$ is a Progressive in politics. $\mathrm{He}$ is a Mason.

\section{James L. Grimes}

Business address, Municipal Hall, Pittsburgh, $\mathrm{Pa}$.

Residence, 5510 Kentucky Avenue, Pittsburgh, $\mathrm{Pa}$.

Knoxville, Pittsburgh, $\mathrm{Pa}$.

James Lee Grimes was born August 14, I88I, in Pittsburgh, Pa., the son of James Fribley Grimes, president of the St. Clair Water Company and the Knoxville Land Company, and Annie Isabel (Fortune) Grimes. His father was a pioneer in the development of real estate in Pittsburgh. His father's parents were American, coming from Fairfax County, Virginia, and his mother's were also American, coming from Zanesville, Ohio. 
He was prepared at the Pittsburgh Academy and spent the year of I90I in study and travel. In 1905 he graduated from Princeton University with the degree of B.S.

$\mathrm{He}$ is unmarried.

Grimes left the Yale Forest School in December, 1906. He traveled in Europe in 1908 and in 1908-09 was a teacher in Shady Side Academy, Pittsburgh, $\mathrm{Pa}$. He was also a member of the Tree Commission of Pittsburgh. Since I9Io he has been city forester of Pittsburgh.

$\mathrm{He}$ is a member of the Methodist church. In politics he is a Progressive.

\section{Burt P. Kirkland}

Business address, Care University of Washington, University Station, Seattle, Wash.

Home address, Box 52, Portage, Wash.

Burt Persons Kirkland was born February 6, $188 \mathrm{I}$, in Silver Creek, N. Y, the son of Albert Kirkland and Annette (Persons) Kirkland. $\mathrm{He}$ is the grandson on his father's side of James Kirkland and Sally Kirkland, and on his mother's side of Horace Persons and Edith Persons. $\mathrm{He}$ is of Scotch and English descent.

He was prepared at the Forestville (N. Y.) High School and in 1905 received the degree of B.A. from Cornell University.

He was married November 18, 1905, in New Haven, Conn., to Miss Rose Pomeroy Kearns of Ithaca, N. Y., daughter of P. F. Kearns and Emmeline Kearns. Mrs. Kirkland died in July, I9r. They had a son, Donald Pomeroy Kirkland, born December 18, 1909, in Ithaca, N. Y.

He was married a second time, September 12, I9I2, in Seattle, Wash., to Miss Bessie M. MacMillan.

Kirkland is associate professor of forestry at the University of Washington, Seattle, Wash., which position he has held since September, I9I2. From July I, I906, to May 3I, I908, he was employed as forest assistant in the United States Forest Service and from June I, 1908, to September 30, 1912, acted as forest supervisor.

$\mathrm{He}$ is a member of the Society of American Foresters and of the Engineers' Club of Seattle, Wash.

He has published: The need of a vigorous policy of encouraging cutting on the national forests, For. Quart.; Working Plans for national forests of the Pacific Northwest, Proc. Soc. Am. Foresters. 


\section{Robinson M. MacMurray}

Business address, Montana State Land Exchange, Helena, Mont. Home address, 33 Oak Avenue, Worcester, Mass.

Robinson Moies MacMurray was born in 1879 in Brooklyn, N. Y.

He was prepared at Adelphi Academy, Brooklyn, N. Y., and at Worcester High School, Worcester, Mass.

He was married June I4, 1909, in Helena, Mont., to Miss Elsie Edith Escher of Harlan, Iowa.

MacMurray is a forester residing in Helena, Mont. He has recently left the position of timber inspector for the Northern Pacific Railroad to take charge of the interests of the State of Montana in the Montana Land Exchange, a project which involves some 700,000 acres of state land with the national forests. $\mathrm{He}$ is field representative for this department.

\section{F. Van Thompson}

Business address, State Hospital Commission, Albany, N. Y. Home address, Marcellus, N. Y.

Thompson is a stenographer for the State Hospital Commission at Albany, N. Y.

\section{Charles M. Walker}

Business address, I 10 East Twenty-third Street, New York City

Charles Morehouse Walker was born in 1879 in South Amherst, Mass. He prepared at the Amherst (Mass.) High School and in 1899 received the degree of B.S. at the Massachusetts Agricultural College. He attended the Yale Forest School during three terms of Junior year.

$\mathrm{He}$ is unmarried.

Walker is in charge of lantern slides with Charles Beseler \& Company, dealers in stereopticons, New York City.

\section{E. LeVerne Wood}

Barceloneta, Porto Rico

Wood is growing citrus fruit in Porto Rico. 


\title{
CLASS OF 1908
}

Graduates holding Degree of M.F.

\author{
Raymond W. Allen
}

United States Forest Service, Cody, Wyo.

Raymond Walter Allen was born September I4, I884, in Medford, N. J., the son of Milton H. Allen and Martha B. (Gaskill) Allen. He is of English ancestry. He has three brothers: Luther M. Allen, M.D. University of Pennsylvania '93, Reginald B. Allen, B.S. Rutgers College '93, M.S. '97 and Ph.D. Clark University '05, and Milton D. Allen, P.D. Philadelphia College of Pharmacy; and one sister, Kate S. Allen, a graduate of Trenton Normal School, New Jersey.

He was prepared at the common schools and by a private tutor and in I906 received the degree of B.S. from Rutgers College, where he was a member of Chi Phi and Cap and Skull, manager of the Track Team and played football.

$\mathrm{He}$ is unmarried.

Upon entering the United States Forest Service Allen became forest assistant in the office of management, Washington, D. C. From December, 1908, to June, 1909, he was chief of the section of timber sales, District 2, in Denver, Colo., and from that time until December, 1909, he did special work in the Service. He was then appointed deputy forest supervisor, which position he held until his present appointment of forest supervisor of Shoshone National Forest, Wyoming, June I5, I9II.

$\mathrm{He}$ is a member of the Presbyterian church and in politics is a Progressive Republican.

\section{Nelson C. Brown}

Business address, New York State College of Forestry, Syracuse, N. Y. Residence, Cor. Ostrom and Waverly Avenues, Syracuse, N. Y.

Nelson Courtlandt Brown was born March I, 1885, in South Orange, N. J., the son of Ashbel Greene Brown, a Civil War veteran, and Lucinda Ann (Van Duyne) Brown. On his father's side he is of English, and on his mother's of Dutch and English ancestry. He has two brothers: 
Irving Van Duyne Brown, Yale 'o2, and David Crane Brown; and one sister, Olive Miriam Brown.

He was prepared at South Orange High School and graduated from Yale College in 1906.

He was married August 23, I9I I, in Milford, Pa., to Miss Alice Virginia Baker of Milford, $\mathrm{Pa}$, daughter of $\mathrm{H}$. T. Baker and Virginia (Halliday) Baker.

Brown is assistant professor of forest utilization in the New York State College of Forestry at Syracuse University. He has held this position since July I, I9I2.

He writes: "In I904 spent the summer on general trip through the forest regions of California, Colorado and the Southwest. Was instructor at Yale Forest Camp at Milford, Pa., between Junior and Senior years at the Forest School. In July, I908, I entered the United States Forest Service, going first to Montana to classify and value the Northern Pacific Railway holdings. The winter of 1909 was spent in Florida, in the interests of the government. During the summer of 1909, I had charge of a survey party on the Gallatin and Absaroka National forests in the neighborhood of Yellowstone Park. While on a furlough, in 1910, at home in South Orange, N. J., I sold bonds for the banking house of Lee Higginson \& Company for awhile."

Again, in 1910, he was instructor at the Yale Forest Camp at Milford, Pa. During I9IO-II he was deputy supervisor of the Kaniksu National Forest in Idaho. He resigned from the Service in I9I , to become assistant professor of forestry in the Iowa State College, at Ames, Iowa. In July, 1912, he entered upon his present position in the New York State College of Forestry.

Brown is a Presbyterian and is a member of the Yale Club of New York City, the Society of American Foresters, the American Forestry Association and the Pennsylvania Forestry Association.

He has written: Reproduction of lodgepole pine in relation to its management, For. Quart., March, 1912; Possibility of reproducing our eastern forests by natural means (read before annual meeting of the Pennsylvania Forestry Association, Bushkill, Pa., 1912). In 1909 he wrote an article, Forest conditions of Florida, which is to be published as a bulletin by the U. S. Forest Service. He has also written miscellaneous articles for the Forestry Quarterly. 


\section{Frederick H. Brundage}

Business address, Care Forest Service, Albany, Ore.

Residence, 1022 West 8th Street, Albany, Ore.

Frederick Herbert Brundage was born December 8, 1884, in Factoryville, Pa., the son of George L. Brundage, M.D., and Lavina (Gardner) Brundage. He has two sisters: Kate (Brundage) Dean and Helen E. Stevens.

He was prepared at Keystone Academy and at Adelphi Academy, and graduated from the Sheffield Scientific School at Yale in 1907, where he was a member of Book and Bond.

He was married December 29, 1909, in Bethel, Maine, to Miss Mary L. Carter of Bethel, Maine, daughter of John H. Carter and Carrie (Clough) Carter. They have one son, George Herbert Brundage, born December 24, 1912, in Bellingham, Wash.

Since the fall of 1912 Brundage has been supervisor of Santiam National Forest with headquarters at Albany, Ore. Before entering the United States Forest Service as forest assistant in 1909, he had been employed by the Great Northern Pulp \& Paper Company of Bangor, Maine. On April I, I9Ir, he was appointed deputy forest supervisor with headquarters at Bellingham, Wash.

$\mathrm{He}$ is a member of the Baptist church.

\section{Elias T. Clark}

\section{University of Washington, Seattle, Wash.}

Elias Treat Clark was born September I, I886, in Woodbridge, Conn., the son of Samuel O. Clark and Carrie P. (Marquette) Clark. His father was a descendant of the early settlers of the state and was a member of the Connecticut legislature and holder of numerous town offices. He has three brothers: Charles Edward Clark, Yale 'II and '14 L., S. Orman Clark and Theodore R. Clark.

He was prepared at the New Haven High School and graduated from the Sheffield Scientific School at Yale in 1907.

$\mathrm{He}$ is unmarried.

Concerning his life since graduation, Clark writes: "Have led a rather uneventful life since leaving the Forest School in June, 1908. Was immediately assigned to the Snoqualmie National Forest with headquarters in Seattle, Wash. Here I 
spent three of the most enjoyable years of my life working under Supervisor Burt P. Kirkland and helping him to bring this great Pacific Coast Forest under forest management. Did the work common to most forest assistants and in addition aided in preparing the provisional working plan for the forest made in 1909 and 1910. A year and a half after assignment to the forest was made deputy supervisor, which position was, held until March, I9II, when I resigned to take charge of the surveying and construction of railroad lines for the Standard Railway \& Timber Company, one of the largest operating timber companies in Washington. Here an interesting and enjoyable summer was spent until October, I9II, when a call came to take a chair of assistant professor of forestry at the Forest School of the University of Washington, to give mensuration courses and to establish a course in logging engineering.

"Have never taken trips far outside of the United States, but have visited most parts of it."

Clark is a Progressive Republican. $\mathrm{He}$ is a member of the Pilgrim Congregational Church of Seattle and the Society of American Foresters.

He made an address before the Pacific Logging Congress on logging engineering, which was published in August, 1912, in numbers of lumber trade journals.

\section{Ernest D. Clark}

Business address, Woodstock, Va. Home address, R. F. D. I, Litchfield, Conn.

Ernest Dwight Clark was born May I4, 1883, in Cornwall, Conn., the son of Andrew Miles Clark and Mary Lydia (Brown) Clark. His greatgrandfather, George Clark, served in the American army in the Revolution and another George Clark was one of the original founders of Milford. His father was a representative from Cornwall to the General Assembly in Hartford in 1895 and has served a number of terms as selectman of the town of Cornwall since that time. He is the grandson on his mother's side of Seth Brown and Lydia (Clark) Brown and said to be a descendant of Peter Brown, one of the Mayflower passengers. He has one brother, Loyal Brown Clark, Yale '08, and four sisters: Sarah Beatrice Clark, Danbury Normal School '12, Marjorie Hazel Clark, Harriet Lydia Clark and Esther Abigail Clark. 
He was prepared at the public schools in Cornwall, Conn., and at the Housatonic Valley Institute, which became in turn the Cornwall School and the Foster School. In 1902 and 1903 he taught in the public schools in Cornwall. In 1907 he graduated from the Sheffield Scientific School at Yale.

He was married June 22, $191 \mathrm{I}$, in Killingly, Conn., to Miss Bertha Marion Branch of Danielson, Conn., daughter of Walter Hamlet Branch, deceased, and Ella Maria Branch, now Mrs. F. H. Greener. They have one daughter, Helen Melissa Clark, born November I0, 1912, in Litchfield, Conn.

Clark is forest assistant in the United States Forest Service. He writes: "July to November, I908, spent in Kentucky under J. S. Holmes studying forest conditions in coöperation with the state. Became thoroughly familiar with corn bread, moonshiners and night-riders. January to July, I909, was in Alabama, for first three months under W. B. Piper. Then was put in charge of making a working plan for the Tennessee Coal, Iron \& Railroad Company. This working plan is notable since it was the last of many perfectly harmless working plans made by the Service for concerns whose only concern was for an estimate of their timber. September to November, I909, lived among the Indians. Had charge of marking timber for the Government mill at Neopit, Wis. July to November, I9ro, worked in Piedmont, N. C., under State Forester J. S. Holmes in coöperation with the state in determining the timber resources of North Carolina. December, I9I0, to April, I9II, assisted W. W. Ashe in a study of second growth in eastern Tennessee. May I5, I9II, transferred from state and private coöperation to Appalachian and sent to New Hampshire to work under K. W. Woodward, examining lands for purchase under the Weeks Law. The last of June came South to take charge of a party examining lands in eastern West Virginia and western Virginia. The first of February, I9I2, made a preliminary examination of the Massanutten Area and recommended its purchase by the Government. From May in general charge of work in the Potomac, Massanutten and Youghiogheny areas in Maryland, Virginia and West Virginia."

$\mathrm{He}$ is a member of the First Congregational Church of Cornwall, Conn., and belongs to the Society of American Foresters and the Free and Accepted Masons. 


\section{Robert E. Clark}

Business address, Forest Service, Leadville, Colo. Residence, zor West Seventh Street, Leadville, Colo.

Forest Service, Washington, D. C.

Robert Eli Clark was born June 9, 1886, in New Haven, Conn., the son of Charles Eli Clark, machine contractor with the Winchester Repeating Arms Company, and Margaret (Davidson) Clark. On his father's side he is of American, and on his mother's of Scotch descent.

He was prepared at the Boardman Manual Training School, New Haven, Conn., and graduated from the Sheffield Scientific School at Yale in 1907.

$\mathrm{He}$ is unmarried.

Clark is acting supervisor in the United States Forest Service, with headquarters at Leadville, Colo. He has held this appointment since July I5, Ig09. Before that he held the position of forest assistant.

$\mathrm{He}$ is a member of the Episcopal church. He is a Mason and a member of the Concatenated Order of Hoo-Hoo.

\section{Arthur M. Cook}

Business address, United States Forest Service, Fraser, Colo. Home address, 135 Academy Street, Laconia, N. H.

Arthur Mayhew Cook was born March 25, 1883, in Laconia, N. H., the son of Addison Gardner Cook and Harriet Stanwood (Hathaway) Cook. $\mathrm{He}$ is of English ancestry. He has a brother, William H. Cook, B.A. Harvard 'o4.

He spent one year in the New England Telephone \& Telegraph Company and attended Phillips Exeter Academy for two years. In 1906 he received the degree of B.A. from Harvard University, where he was a member of Theta Delta Chi.

He is unmarried.

Cook was appointed supervisor of the Arapaho National Forest with headquarters at Fraser, Colo., in July, I9Io. Previous to this he had held the positions of forest assistant and deputy forest supervisor in the United States Forest Service.

$\mathrm{He}$ is a member of the Society of American Foresters. 


\section{John A. Ferguson}

Business address, Pennsylvania State College, State College, Pa.

John Arden Ferguson was born December 23, 1873, in Canandaigua, N. Y., the son of Harrison Boggerly Ferguson, lieutenant in the Civil War and county treasurer, and Ella Clara (Woder) Ferguson. On his father's side he is of Scotch ancestry. He has two sisters: Clara Louise (Ferguson) Henson, a graduate of Albany Normal School, and Julia May Ferguson; and one brother, Dr. Harry N. Ferguson, D.D.S. Philadelphia Dental College.

He was prepared at Canandaigua Academy, N. Y. In 1896 he received the degree of B.A. from Hamilton College and in 1903 the degree of M.A. At college he was a member of Chi Psi and Delta Theta Sigma. Before entering the Yale Forest School he taught at the Brooklyn Polytechnic Institute and at Rutgers Preparatory School, New Brunswick, N. J.

He was married September I4, 19II, in Allentown, Pa., to Miss Susan Kathryn Becker of Allentown, daughter of William Becker.

After graduation from the Yale Forest School Ferguson became forest assistant in the United States Forest Service with headquarters in the Boise National Forest. In the same year he was appointed instructor in the forestry department of the Pennsylvania State College and in 1909 was made assistant professor. During I909-Io he was in charge of the department. In the summer of I9IO-II he acted as instructor in the Yale Forestry Camp, and in I9I I he founded the department of forestry at the University of Missouri, himself holding the position of professor. Since January, I9I3, he has been director of the College of Forestry at Pennsylvania State College.

In politics he is a Republican (independent and progressive). $\mathrm{He}$ is a member of the American Forestry Association, the Conservation Association, the National Geographic Society, the Pennsylvania and Canadian Forestry associations, the Society of American Foresters, the Society of Eastern Foresters and a fellow of the American Academy of Arts and Sciences. $\mathrm{He}$ is a Mason. In I9II-I2 he was a delegate to the Conservation Congress and in 1912 delivered an address before the State Conservation Congress.

He has published: How to prolong the life of fence posts, Circ. 5I, Mo. Agric. Exp. Sta.; Growing a woodlot from seed, Circ. 52, Mo. Agric. Exp. Sta. He made an address on Forest Leaves before the Pennsylvania Forestry Association, July, 1909. 


\title{
H. Earl French \\ Halsey, Neb.
}

Hiram Earl French was born June 24, 1883, in Humboldt, Iowa, the son of Hiram A. French and Jane Eliza (McCollough) French. He has one brother, Elmer C. French, and two sisters: Nellie E. French and Jennie B. French.

He was prepared at Humboldt (Iowa) High School and received the degree of B.S. from the State University of Iowa in 1906.

He was married November 2, 1911, in Kenosha, Wis., to Miss Janet Esther Hewitt of Livermore, Iowa, daughter of Amos A. Hewitt and Eliza Hewitt.

French entered the United States Forest Service on July r, 1908. $\mathrm{He}$ is now supervisor of the Nebraska National Forest with headquarters at Halsey, Neb.

$\mathrm{He}$ is a Free and Accepted Mason.

\author{
Jesse R. Hall \\ Business address, Yreka, Siskiyou County, Calif. \\ Residence, Bostonia, San Diego County, Calif.
}

Jesse Rexford Hall was born September 12, 1882, in Blendon, Mich., the son of Jesse Phillips Rexford Hall, a farmer and formerly superintendent of schools in Blendon County, Mich., and Charlotte (Abbott) Hall. He has four brothers: W. D. Hall, engaged in contracting and building; Julian D. Hall, a farmer; Samuel C. Hall, a business man and attorney at law in Los Angeles, Calif.; and Arthur Nelson Hall, B.S. University of California 'o7, an electrician. He also has two sisters: Marie E. Hall, a normal school teacher, and Helen Hall, a domestic science teacher. Another brother, Burdette C. Hall, and two sisters, Rosa and Mary Hall, are deceased.

He was prepared at the El Cajon Union High School, California, and in 1905 received the degree of B.S. from the University of California.

He was married October 23, 1911, in Bostonia, San Diego County, Calif., to Miss Olive Corinne Somers of Santee, Calif., daughter of W. H. Somers and Sarah Somers.

Hall is deputy forest supervisor in the United States Forest Service with headquarters in Klamath National Forest, California, which position he has held since January I, I9Io. Previous to this he was forest assistant in Plumas National Forest, California. 
$\mathrm{He}$ is a member of the Presbyterian church and in politics was formerly a Republican, but now a Progressive.

\section{R. Clifford Hall}

\section{United States Forest Service, Washington, D. C.}

R[ufus] Clifford Hall was born October 30, I885, in Chicago, Ill., the son of Rufus C[lifford] Hall and Mary Elizabeth (Platt) Hall. His father's parents were New Hampshire merchants and his mother's Michigan merchants. $\mathrm{He}$ has two sisters: Fanny Aline Hall, Ph.B. Northwestern University ' 96 , and Eliza Platt Hall, B.S. Northwestern University ' 99 and M.S. 'oo.

He was prepared at the Chicago public schools and at the Lake View High School, Chicago, and in 1906 received the degree of B.S. from Northwestern University, where he was elected to Phi Beta Kappa.

$\mathrm{He}$ is unmarried.

Hall has been forest assistant in the United States Forest Service since July I, I908, with headquarters at Washington, D. C. He writes: "I have traveled on professional work through the Middle West and South, mostly in Illinois, Kentucky, Tennessee, North Carolina and Georgia. Have also been on a sight-seeing trip in the West-Yellowstone Park-in the summer of I910."

$\mathrm{He}$ is a member of the Presbyterian church and in politics is a "National Progressive." $\mathrm{He}$ is a member of the Society of American Foresters and at Yale was elected to Sigma Xi.

\section{William C. Latané}

\section{Libby, Mont.}

William Catesby Latané was born September 17, 1883, in Oak Grove, Va., the son of William Catesby Latané, an Episcopal minister, and Susan (Wilson) Latané. His ancestors on his father's side were French Huguenots and early settlers in Virginia. $\mathrm{He}$ is the grandson on his mother's side of John Wilson of Maryland and Elizabeth (Washington) Wilson of Wakefield, Va.

He was prepared at Wirtland Seminary and in 1905 received the degree of B.S. from the Virginia Polytechnic Institute.

He was married April 27, 1912, in Spokane, Wash., to Miss Mary Stuart Lindsay of Baltimore, Md., daughter of George Winston Lindsay and Ida (Stuart) Lindsay. 
Since entering the United States Forest Service in 1908 Latané has been forest assistant with headquarters in 1908-09 in Bighorn National Forest, in 1909-IO in Kaniksu National Forest, and from I9Io to I9I3 in Kootenai National Forest, District I. He is now deputy supervisor in Kootenai National Forest.

$\mathrm{He}$ is a member of the Episcopal church.

\title{
Charles A. Lewis
}

Business address, I20 Oak Avenue, Ithaca, N. Y. 3 West Fifty-fourth Street, New York City

Charles Augustus Lewis was born February 22, 1871, in New London, Conn., the son of James Ivers Lewis, president and treasurer of the Uncasville Manufacturing Company of Uncasville, Conn., and a life trustee of Trinity College, and Susan (Kidder) Lewis. $\mathrm{He}$ is the grandson on his father's side of Charles A. Lewis and Adelaide A. (Richards) Lewis, and on his mother's side of Edward Kidder and Anne (Potter) Kidder. He has a sister, Annette A. Lewis.

He received the degree of B.A. in 1893 from Trinity College, Hartford, Conn., where he was a member of Delta Psi.

$\mathrm{He}$ is unmarried.

From July, I908, to January, I909, Lewis was forest assistant in the United States Forest Service and during the year of I9I0-I I was engaged in the hardware business. He is at present a student at Cornell University.

$\mathrm{He}$ is a member of the Protestant Episcopal church and in politics is a Republican. He is a member of the University Club of New York City and of the Cape Fear Country Club of Wilmington, N. C.

\author{
Forman T. McLean \\ Business address, Ephraim, Utah \\ Home address, Eatontown, N. J.
}

Forman Taylor McLean was born June 28, 1885, in Colt's Neck, N. J., the son of John Hull McLean, whose father was Amzi Chapin McLean, and Eliza H. (Taylor) McLean, whose father was Tunns Forman Taylor. He has one brother, Amzi Chapin McLean, and one sister, Annie Haight McLean.

He was prepared at Red Bank (N. J.) High School and at Shrewsbury Academy, and graduated from the Sheffield Scientific School at Yale in 1907.

$\mathrm{He}$ is unmarried. 
McLean is deputy supervisor in the United States Forest Service with headquarters at Ephraim, Utah. He has held this appointment since December I, I9II. He entered the Service on July I, I908, as forest assistant, which position he held until he received his present appointment.

$\mathrm{He}$ is a member of the Society of American Foresters.

\title{
Harvey R. MacMillan
}

\author{
Business address, Forest Branch, Victoria, B. C., Canada
}

Harvey Reginald MacMillan was born September 9, 1885, in Newmarket, Ontario, the son of John Alfred MacMillan, holder of local municipal offices, and Joanne Caroline (Willson) MacMillan. His grandfather came from Scotland and his grandmother was a United Empire Loyalist. His mother's family was loyal to the United Empire. They settled in the United States about 1690 and went to Canada in $1760^{\circ}$ and 1780 .

He was prepared at the (Adelphi Academy and Worcester High School) and in 1906 graduated from the Ontario Agricultural College, Toronto University, with the degree of B.S.A. Since 1903 he has spent his summers with the Dominion Forestry Branch. He had charge of the first forest survey in Canada.

He was married August 2, I9II, in Aurora, Ontario, to Miss Edna Mulloy of Aurora, daughter of Charles Wesley Mulloy and Gertrude (Claflin) Mulloy. They have a daughter, Edna Marion MacMillan, born June 16, 1912.

MacMillan is chief of the Forest Branch of British Columbia, Canada. From I908 to I9I I he was assistant inspector of forest reserves and assistant director of forestry from I9II to July I5, I9I2, when he received his present appointment.

He writes: "I have recently left the service of the Dominion Forestry Branch, and am at present chief forester of the Provincial Forest Branch, recently established to administer the public forest lands of the province of British Columbia.

"British Columbia covers about 350,000 square miles, and is very similar in character to Washington, Oregon and Idaho. The timber in the southern portion of the Province is similar to that north of the $45^{\text {th }}$ parallel of latitude, and west of the I I5th parallel of longitude in the United States, with the difference that the valleys in British Columbia are narrower, and 
the mountains are steeper and higher, and there is a smaller proportion of very heavy timber. In the northern portion of British Columbia the timber consists chiefly of spruce and large pine, and does not extend far from the rivers and lakes.

"The merchantable area of the Province has been estimated at from 50 to 60 million acres.

"The Government has pursued the policy of refusing to part with the title of timber land. Only about one million acres of timber land have been granted in fee simple to private parties. About nine million acres of timber land have been leased to private individuals. The remainder of the forest land, consisting chiefly of timber at present considered inaccessible, and all burned-over land covered with reproduction is still in the hands of the Crown.

"The present revenue of the Province from timber leases and from the royalty of 50 cents per thousand charged on all timber cut amounts to $\$ 2,600,000$ per year. This revenue will be largely increased as the development proceeds. The indications are now that there will be a rapid advance in the next few years.

"The new Forest Branch has been formed under the guidance of Mr. Pinchot and Mr. Price, to administer the timber lands and to develop the country by a wise forestry policy for the Province. The Forest Branch is very young. There are at present about twenty foresters, but the indications are that the staff will need to be very largely increased during the next two or three years. In order that the rangers and foresters may be secured it is the intention of the Government to establish a forestry school in connection with the new provincial university."

$\mathrm{He}$ is a member of the Presbyterian church. In I9Io he was appointed Canadian representative to the Convention of the International Association of Forest Experiment Stations at Brussels. He is a member of the Canadian Society of Forest Engineers, of which he is a member of the executive committee, the Ottawa Field Naturalists Society, the Ontario Entomological Society and the Canadian Alpine Club, and is a Mason.

He has published: Forest conditions, Crowsnest Valley, Alta.; Forest products, Canada, 1908; Forest fires, Canada, 1908 and 1910; Lumber, lath shingles, Canada, 1909 and I910; Poles purchased, Canada, I909, I9I0 and I9II; Pulpwood, Canada, 1909, I910 and I9II; Cross ties pur- 
chased, Canada, I909 and I9I0; Mining timbers, Canada, I910; Tight slack cooperage, Canada, 1909 and I9ro; Tanning materials, Canada, I909; Annual Report, Dept. of Interior, Canada, I909, I9II and 1912; numerous articles in Canadian periodicals.

\section{Willis N. Millar}

\section{Business address, Box 1253, Calgary, Alta., Canada}

Residence, 1228 Boulevard, N. W., Calgary, Alta., Canada

Willis Norman Millar was born October 18, I883, in Pittsburgh, Pa., the son of W. N. Millar and Mary A. (Drum) Millar. He is of Scotch ancestry. He has a brother, Bruce D. Millar, B.S. University of Pennsylvania, and a sister, Sylvia C. Millar.

He was prepared at the Pittsburgh High School and in I906 graduated from the University of Pennsylvania with the degree of B.S.

He was married June 29, 1908, in Pittsburgh, Pa., to Miss Lucy May Cook of Pittsburgh, daughter of Charles W. Cook and Emma S. Cook. They have a daughter, Lucy Elizabeth Millar, born August 5, 191 I, in Newport, Wash.

Millar is inspector of forest reserves in the Forestry Branch of the Department of the Interior, Canada, in the Alberta District. Previous to this he was employed in the United States Forest Service, first as forest assistant and later as forest supervisor. He entered upon his present position March I3, I9I2.

$\mathrm{He}$ is a member of the United Presbyterian church and in politics is a Progressive Republican. He is a member of the Society of American Foresters.

\section{Robert B. Miller}

Business address, Department of Forestry, Fredericton, N. B., Canada Home address, Box 256, Thorntown, Ind.

Robert Barclay Miller was born September 15, 1875, in Lincoln, Neb., the son of Jacob S. Miller, a farmer, and Jane (Armstrong) Miller. His father's ancestors were natives of Kentucky. His mother's father came from Ireland and lived in Conneaut, $\mathrm{Pa}$.

He was prepared at the Thorntown High School, Thorntown, Ind., and in I 896 received the degree of B.S. from Wabash College, Crawfordsville, Ind., where he was a member of Phi Kappa Psi. In 1906 he received the honorary degree of M.A. from Wabash. In 1897-98 he was assistant principal of the Thorntown High School and during the two years 
following was engaged in newspaper work. In 1899 he was appointed professor of natural science at the Rochester Normal School, Rochester, Ind., which position he held for four years. In the summer of 1899 he studied at the University of Chicago. He was professor of natural science one year at Dakota Wesleyan, Mitchell, S. Dak., and from 1904 to 1906 held the same position at Huron College, Huron, S. Dak.

$\mathrm{He}$ is unmarried.

Miller is at present dean of the Department of Forestry at the University of New Brunswick. He entered upon this position in September, I909. He writes: "Was called to the University of New Brunswick when the Department of Forestry was founded in provincial university in 1908. Now have about twenty-five students and have graduated three classes in forestry. Graduates are taking positions with lumber companies, paper companies, Dominion Forestry Branch, Canadian Pacific Railroad Forestry Branch, and have three men with British Columbia Branch, Victoria, B. C. Received gold medal for best exhibit of woods at Dominion Exhibition, St. John, N. B., in fall of 19I0. In the fall of 1912 was appointed forester by the Senate of the University of New Brunswick, having charge of 3,600 acres of college lands. Beginning to make an estimate and working plan for same, with the coöperation of the Forestry Branch, Ottawa. In fall of 1912 built a camp on this land and am trying to give a good, practical, undergraduate course in forestry."

Miller is a member of the Presbyterian church.

He has published articles in the Canadian Forestry Journal and Canadian Lumberman, and is writing an article on Forest resources of the maritime provinces for a book entitled "Canada and its provinces," to be published by Robert Glasgow, Toronto, Canada.

\section{Barrington Moore}

\section{United States Forest Service, Washington, D. C.}

Barrington Moore was born September 25, 1883, in Ossining, N. Y., the son of Clement Clarke Moore, an architect and a captain in the 22d Massachusetts Regiment in the Civil War (deceased), and Laura Martha (Williams) Moore. $\mathrm{He}$ is the grandson of Benjamin Moore and the great-grandson of Clement Clarke Moore, the author of "The Night Before Christmas." On his mother's side he is the grandson of William S. Williams. He has two brothers: William S. Moore and Benjamin 
Moore, Harvard '08. A cousin, Benjamin B. Moore, graduated from Yale in 1899.

He was prepared at St. Mark's School, Southboro, Mass., at Craigie's School and at the Morristown School, Morristown, N. J. In 1906 he graduated from Yale College, where he received a Junior dissertation appointment and engaged in football and track athletics. His fraternity was Alpha Delta Phi. During the summer after his junior year in college he worked as student assistant in the United States Forest Service in North Carolina.

He was married December 20, I9Io, in New York City, to Miss Muriel Hennen Morris of New York City, daughter of Thurlow Weed Barnes and Isabel (Morris) Barnes. They have a son, Clement C. Moore, born May 12, 1913, in Washington, D. C.

Moore is forest examiner in the United States Forest Service, being engaged in the construction of working plans at the Washington office. He has been engaged in this work since July, I909. Of his life since graduation from the Forest School, he wrote in 1911: "The year following graduation I spent studying forest problems in all the important foreign countries where forestry is practiced. The trip was interesting, not to say exciting in spots, particularly the four months in India, where I tried conclusions with a wild buffalo and a tiger, successfully in the case of the latter. On my return to the United States, July I, I909, I entered the United States Forest Service and was sent to District 3, the Southwest headquarters, Albuquerque, N. Mex. My work has been almost entirely what is called reconnaissance-mapping and estimating timber for the future management of the forests."

$\mathrm{He}$ is a member of the Protestant Episcopal church. $\mathrm{He}$ is a member of the Yale Club and Chevy Chase Club.

He has published: (With R. L. Rogers) Notes on balsam fir, For. Quart., Spring, 1908; Notes on forests of northern India and Burma, Indian Forester, April and May, 1909; Forestry in Japan, Am. For., about Aug., I909; Forestry problems in the Philippines, Am. For., about March and April, I910; Some methods of regulating the cut in the coniferous forests of the Himalayas, For. Quart., I9Io; Checking the floods in the French Alps, Am. For, about April, 1910; (With R. L. Rogers) A method of assessing fire damage, For. Quart., Summer, I9II; Nomenclature of divisions (or areas) in forest working plans, For. Quart., Fall, I9II; Management of western yellow pine in the. Southwest, For. Quart., Ist no., 1912; Essentials in forest working plans, Proc. Soc. Am. Foresters, VI, No. 2; Methods of regulating the cut for national forests, Proc. Soc. Am. Foresters, VII, No. I. 


\section{Thornton T. Munger}

Business address, Forest Service, Portland, Ore.

Home address, 202 Prospect Street, New Haven, Conn.

Thornton Taft Munger was born October 3, 1883, in North Adams, Mass., the son of Rev. Theodore Thornton Munger, D.D., Yale '51, and Elizabeth Kuirman (Duncan) Munger, who died in 1883. His father was a Congregational minister, having received the degree of D.D. from Harvard and Yale, and was a member of the Yale Corporation and of the National Institute of Arts and Letters. He is the grandson, on his father's side, of Ebenezer Munger, a physician, Yale 1814, and Cynthia (Selden) Munger, of Connecticut, and the great-grandson of Eleazar May, Yale 1752. On his mother's side he is the grandson of James $\mathbf{H}$. Duncan, Harvard I8I2, and LL.D. Brown I86I, a lawyer and member of Congress, and Mary (Willis) Duncan, both of Massachusetts. He has three sisters: Rosanna May Munger; Eleanor Duncan (Munger) Wells, wife of Philip P. Wells, Ph.D. '89, of Washington, D. C.; and Elizabeth Willis (Munger) Adams, wife of Professor John C. Adams, Yale '96, of New Haven, assistant professor of English at Yale.

He was prepared at the New Haven High School and at the Hotchkiss School, and graduated from Yale College in 1905, and was active in Dwight Hall work. He spent the year of $1905-06$ abroad, three months of which were devoted to study of forestry in Germany.

He is unmarried.

He writes: "On entering the Forest Service, July I, I908, I was assigned to the Section of Silvics and after six weeks in Washington I was sent to Oregon to make a study of 'the encroachment of Lodgepole pine on western yellow pine on the east slope of the Cascades in Oregon.' Upon the completion of this study, December I, I908, I was assigned to the Section of Silvics as the chief in the newly established district office of the Forest Service in Portland, Ore. This position I have since held. My work has consisted in making a large number of silvical studies in the National Forests of this region and of field work in connection with timber sales and reconnaissance. A little over half my time has been spent in Portland and the balance in the field in various parts of Oregon and Washington."

Munger is a Progressive Republican. He is a member of the United Church (Congregational) of New Haven. He belongs to the Society of American Foresters, the Concatenated Order of Hoo-Hoo, the Irvington Tennis Club and University Club, both of Portland. 
He has published: The growth and management of Douglas fir in the Pacific Northwest, Circ. I75, U. S. Forest Service; Avalanches and forest cover in the northern Cascades, Circ. I73, U. S. Forest Service.

\section{Robert L. Rogers}

Care United States Forest Service, Washington, D. C.

Robert Landon Rogers was born October I2, I883, in Westerly, R. I., the son of Frederick Tuttle Rogers, M.D., Union College '80, and Carrie (Garitt) Rogers (died June 25, 1900). He has one brother, Fred Alexander Rogers, Yale ' 08 S., and one sister, Ruth Louise Rogers.

He was prepared at the public and private schools at Providence, R. I., and in 1906 graduated from Yale College, where he was editor of the Yale Banner in 1905 and a member of the Class Hockey Team his Senior year, of the French and German clubs and of the Elihu Club.

$\mathrm{He}$ is unmarried.

Rogers is at present doing editorial work for the United States Forest Service with the position of forest examiner. Since he has been in the Service he has held successively the positions of forest assistant, deputy forest supervisor and forest supervisor. He writes: "Entered Forest Service in July, 1908, and until December, 1908, was engaged in planting and coöperative examinations in the East and Middle West. From December, 1908, to December, 1912, have been in forest and district work in Arizona and New Mexico-since December, I912, in Washington, D. C.-all the time with Forest Service."

$\mathrm{He}$ is a Progressive in politics. $\mathrm{He}$ is a member of the Concatenated Order of Hoo-Hoo.

\section{Julian E. Rothery \\ Business address, II33 Broadway, New York City \\ Home address, Wellesley, Mass.}

Julian Eastman Rothery was born April 13, 1885, in Longwood, Mass., the son of John Jay Elmendorf Rothery, who is associated with the fire insurance business, real estate and architecture, and Rose (Pentecost) Rothery. He has one brother, John Loring Rothery, and three sisters: Rosamond Flower (Rothery) Vitale, Agnes Edwards Rothery, Wellesley 'og, and Margaret Elmendorf Rothery. 
He was prepared at the Wellesley High School and graduated from the Sheffield Scientific School at Yale in 1907.

$\mathrm{He}$ is unmarried.

Rothery is at present junior partner in the firm of Vitale \& Rothery, landscape architects. He entered upon his present position January I, 1912. While in the Service he held first the positions of forest assistant and deputy forest supervisor in the Cache National Forest, Utah, and later that of supervisor of the Idaho National Forest. He writes: "During my stay in Utah (two years), I had charge of winter work in the forestry department of the State Agricultural College. Promoted July r, I9Io, to supervisor of the Idaho National Forest. Fought the historical fire of 1910 so that now hell has no terrors for me. Had two years as supervisor of the most isolated forest in the world and enjoyed it all."

Concerning his travels, he says: "I have visited most of the western states and regions of interest. Spent the winter and summer of 1912 exploring in the Labrador Peninsula on snowshoes and dog teams."

$\mathrm{He}$ is a member of the Society of American Foresters and of the Yale Club of New York City.

He has written: Ranger courses, For. Quart., June, I909; article in Hunter, Trader, Trapper Mag., April, I9I3; also articles on the Forest Service in the Tounsman.

\section{Edward B. Starr}

Busines address, Forest Service, Schmitt-Hunt Building, Albany, Ore. Cornwall, Conn.

Edward Burgis Starr was born April 29, 1884, in Northfield, Conn., the son of Rev. Edward Comfort Starr, Yale '66, a trustee of the Cornwall School and Library, and Emily Amelia (Shew) Starr. $\mathrm{He}$ is the grandson, on his father's side, of John Shipman Starr and Lydia A. (Lay) Starr, and on his mother's side of Charles Jackson Shew and Martha Delia (Winship) Shew. He has one sister, Mabel Emily Starr, and one brother, Charles Comfort Starr, Yale 'oo S., and M.A. Columbia 'o2.

He was prepared at the Housatonic Valley Institute, Cornwall, Conn., and graduated from Yale College in 1907 , where he received a first colloquy Junior appointment and was a member of the Baseball Team. 
He was married January 20, I9II, in Eugene, Ore., to Miss Mary Augusta Young, of Eugene, Ore., daughter of Carl Henry Young and Mary (Blatchley) Young. They have one daughter, Adelaide Emerson Starr, born February I4, I912, in Albany, Ore.

Starr is forest assistant in the United States Forest Service with headquarters in Albany, Ore. He entered the Service July I, 1908, at that time being stationed in Washington, D. C. Since then his appointments have been at Portland, Ore., the Cascade National Forest and, at present, the Santiam National Forest.

$\mathrm{He}$ is a member of the First Baptist Church of Eugene, Ore. $\mathrm{He}$ is state fire warden and a deputy game warden.

\section{Dillon P. Tierney}

Business address, State Capitol, St. Paul, Minn.

Residence, 699 Lincoln Avenue, St. Paul, Minn.

Dillon Parnell Tierney was born March 4, 1882, in Farmington, Minn., the son of Thomas Tierney and Mary (Sullivan) Tierney. $\mathrm{He}$ is of Irish ancestry. He has four brothers: Edward, Arthur, Charles and Phillip Tierney, and two sisters: Alice and Mayme Tierney.

He was prepared at the Farmington High School, Farmington, Minn., and at an agricultural school, and in 1906 received the degree of B.Sc.F. from the University of Minnesota, where he was a member. of Alpha Zeta.

He was married November 15, 1910, in Minneapolis, Minn., to Miss Esther A. Day of Owatonna, Minn., daughter of Levi E. Day. They have a daughter, Helen Louise Tierney, born February 2I, I9I2.

After graduation from the Yale Forest School Tierney became forester for the Kaul Lumber Company and was later employed in the United States Forest Service. He was then appointed instructor in the University of Minnesota, being placed in charge of the Forest Experiment Station. Since May I5, I9II, he has held the position of assistant state forester of Minnesota.

He writes: "The first organized attempt to carry on forestry work in Minnesota was authorized by the passage of the I9II Forest Law. A few months later I undertook to hold down the job of assistant state forester. In this position I have had a 
try at nearly every phase of forestry work that one could imagine.

"Fire protection was of course the first work. At the outset we assumed that the majority of fires could be prevented simply by having the right kind of men distributed throughout the forest district, to remind people of the dangers of fire and also point out situations where dangerous fires are liable to occur. This naturally led us to the question of handling fires which originate from railroad rights-of-way and to the disposal of slash following logging operations.

"The railroads are now working in complete harmony with this department, not only to prevent fires being started from their locomotives, but also to extinguish any which may start near the rights-of-way. They now realize that it is money well spent to prevent fires on their rights-of-way, and also-what is of more importance to us-that the care of railroad fires rests with the companies themselves.

"Our district rangers have been selected with the greatest care, and it is on them we depend for working out the details of slash disposal on practically every logging job or woods operation in the state. We have of course made it clear to the rangers what are the objects of slash disposal, but it is up to them to decide on the methods which will fulfill these objects. Under certain conditions the slash must be disposed of as logging proceeds; under others it must be burned in the early spring; or it may be sufficient simply to dispose of the slashings for a specified distance on either side of all logging roads and on the boundaries of the logged-over tract.

"We have divided the forested area of the state into fourteen large districts, with a ranger in charge of each. Under each ranger there are patrolmen, the number of whom varies with the necessity of patroling against the spread of fires. Aside from this force, each railroad company provides patrolmen sufficient to protect their rights-of-way. The lumber and mining companies provide patrolmen of their own accord or when requested to do so. A number of the townships have also levied a special tax, to pay for a township patrolman and provide a fire fighting fund. Telephones, trails, cabins and lookout towers have been constructed to aid in the fire protection work. 
"The opportunities for forestry work, I believe, are the best in this state of any east of the Rockies. A great quantity of timber is still uncut, and its utilization is a field in which the forester may help. At present only a small area of land is under the exclusive management of this department. The disposal of three and one-half millions of acres of state school lands is provided for in the state constitution, but since a great deal of this land is suitable only for growing timber, the constitution will eventually be changed so that the forest land can be handled as such. Aside from this there are millions of acres of privately owned land which must in time come back to the state and will be used for the growth of timber. We are gathering data to show the character and extent of all such nonagricultural lands and when we have gathered sufficient data the matter will be in shape for legislation. We have estimated the amount of non-agricultural land in the state which should be kept growing timber continuously, at about fifteen million acres. To acquire such an amount of land and put it under forest management looks like some job for the foresters."

$\mathrm{He}$ is a member of the Roman Catholic church. $\mathrm{He}$ is a member of the Conservation Association, the American Association for the Advancement of Science and the Knights of Columbus.

\section{Wilford B. Willey}

\section{Saint Maries, Idaho}

Wilford Bennett Willey was born March 2I, I883, in Nunda, N. Y., the son of Wilford E. Willey and Clara Adelaide (Bennett) Willey. He is of Scotch-Irish ancestry on his father's side and on his mother's of English descent. He has a brother, Floyd Arthur Willey, B.M. Ithaca Conservatory of Music.

He was prepared at the Ithaca High School, Ithaca, N. Y., and in 1907 graduated from Cornell University with the degree of B.A.

He was married June I6, I912, in Kooskia, Idaho, to Miss Rhoda Margaret Fenn of Kooskia, daughter of Major Frank Alfred Fenn and Florence A. Fenn.

Willey is forest assistant in the United States Forest Service with headquarters at Saint Maries, Idaho. $\mathrm{He}$ has held this position since July I, I908.

$\mathrm{He}$ is a member of the Episcopal church. 


\title{
Hubert C. Williams
}

\author{
Business address, McCall, Idaho \\ Home address, Lakeville, Conn.
}

Hubert Coffing Williams was born August 22, I884, in Lakeville, Conn., the son of Hubert Williams and Claire Kingman (Coffing) Williams. His father held the positions of state representative, president of the State Fish and Game Commission, postmaster, president of the Litchfield County University Club and president of the County Bar Association. He has one sister, Margaret Holly Williams.

He graduated from the Sheffield Scientific School in 1906, where he was a member of Delta Phi.

$\mathrm{He}$ is unmarried.

Williams is deputy supervisor in the Idaho National Forest. From July, 1908, to July, I910, he was in the employ of the Goodman Lumber Company, Goodman, Wis. While in this position he was first postmaster of Goodman, Wis. "On May 8, I9I I," he writes, "left home for Ogden, Utah, with a letter from the district forester appointing me forest agent. Upon my arrival at McCall was informed that my position was forest guard. I was soon made temporary forest assistant and am now forest assistant. June 24, I9II, sent on foot by Supervisor J. E. Rothery to Copenhaver Ranger Station to secure Walter Gackel's (ranger) oath of office. Distance forty miles over about ten miles of crusted snow that hid the trail blazes for long stretches on the summits. Streams were all full, making occasional long detours necessary to find foot logs. Got into one trap line, mistaking blazes for the trail blazes, never having been over the route before. Left McCall at 9:30 A. M. on the 24th and had oath of office in the supervisor's office in McCall at 8 o'clock, June 25th.

"Mixed it up with a family of bears-an old she and two cubs on July 26, 1912, while on timber reconnaissance. Treed the cubs and went between them and 'the Mrs.' As she came back shot her with a Luger pistol (.30 cal.) and then got one of the cubs."

Concerning his politics, Williams writes: "Not identified with any party, voting for the man whom I consider best qualified to fill the office for which he is candidate." 


\section{Graduates holding Certificate but not Degree}

\section{Chester B. Cox}

Business address, Bureau of Forestry, Baguio, P. I. Home address, Santa Maria, Calif.

Chester Boyd Cox was born September 9, I883, in Santa Maria, Calif., the son of Alvin Warner Cox, supervisor of Santa Barbara County, mayor of Santa Maria and a pioneer farmer in the Santa Maria Valley, and Mary Adelaide (Powers) Cox. On his father's side he is of English ancestry through Captain Bradford of Plymouth, and on his mother's of Irish and Scotch descent. He has two brothers: Asbury Moses Cox and Arthur Elmer Cox.

He was prepared at the Santa Maria Union High School and attended the College of Agriculture at the University of California.

He was married November 12, I9II, in Manila, P. I., to Miss Ruby Lucy Bryant of Santa Maria, Calif,, daughter of Emmett Trott Bryant and Laura (Sharpe) Bryant.

Cox is forester in the Bureau of Forestry, Philippine Islands, engaged in the beautification of Baguio. In 1908-09 he held the position of forest assistant in the United States Forest Service. In 1909 he was sent as forester to the Philippine Islands, where, from I909 to I9I I, he was in charge of Bataan and Arayat forests and in I9II-I2 in charge of the North Central Luzon District. His headquarters have been at Baguio since I9I2.

$\mathrm{He}$ is a member of the Episcopal church. In politics he was a Republican from 1905 to I9II, when he became a Progressive. $\mathrm{He}$ is a member of the Advisory Board to the Director of Forestry, the Concatenated Order of Hoo-Hoo and the Loyal Order of Moose.

\section{Joseph A. Fitzwater}

\section{Sandpoint, Idaho}

Joseph Albert Fitzwater was born March 20, I884, in Phœnixville, Pa., the son of Albert Fitzwater and Letitia (Vanderslice) Fitzwater. His father is engaged in the carriage and automobile business. $\mathrm{He}$ is the grandson on his father's side of Joseph Fitzwater and Fannie (Pennypacker) Fitzwater and on his mother's side of Addison Vanderslice and Caroline (Murray) Vanderslice. $\mathrm{He}$ has a sister, Caroline Murray Fitzwater, who attended Cornell College, Mt. Vernon, Iowa, for three years. 
He attended Juniata College, Huntingdon, $\mathrm{Pa}$., after which he spent a year with the Phøenix Iron Works, where he did clerical work. In 1903 he attended the Yale Summer School and later was student assistant in the United States Forest Service. He studied and assisted his father one year and the next year attended Ursinus College, Collegeville, $\mathrm{Pa}$.

$\mathrm{He}$ is unmarried.

Fitzwater is supervisor in the United States Forest Service with headquarters in Pend Oreille National Forest, which position he has held since August, 1912. He writes: Went to Flagstaff, Ariz., in July, 1908. Spent one month in reconnaissance work on Coconino National Forest. The following month reported to Frank Vogel, Denver, Colo. Was on reconnaissance on Pike National Forest until November and had charge of a party the last month and a half. Upon completion of work had working plan report to make--some kind of job, with no data. Reported at Missoula, District $\mathrm{I}$, in December. Balance of winter and spring (1909) worked out of district office on Kaniksu, Kootenai and Pend Oreille forests. In July went to Absaroka as deputy supervisor and swung the boundary work; upon its completion was called to Missoula again. Had crew up North Fork Flathead River estimating Great Northern and St. Paul \& Milwaukee rights of way. Work stopped in December and was sent to Kaniksu to complete the laying out of the blocks on section 26, fidelity sale (made the original contour map of this the previous spring). In January, I9I0, was called to Missoula and spent three months in district office; spent time in volume table work and in teaching at the Ranger School, University of Montana. In April was sent to Superior National Forest as acting forest supervisor and am now supervisor. Have had some good experiences and some not so good. I've traveled by foot and horse, but at present I'm developing web feet."

In politics he is a Republican. He is director of the Ely Club.

\section{Francis M. Patton}

Business address, 95 Charlotte Street, Asheville, N. C.

Francis McLeod Patton was born August 20, 1880, in Asheville, N. C., the son of Thomas Walton Patton, captain in the Confederate Army, adjutant in the Spanish-American War and mayor of Asheville for three 
terms, and Martha Bell (Turner) Patton. He is of Scotch and ScotchIrish ancestry. He has a sister, Josie Buel Patton.

He attended grammar school in Sewanee, Tenn., the Biltmore Forest School and the University of North Carolina, where he was a member of Beta Theta Pi. For two years before entering the Yale Forest School he was employed in the United States Forest Service as student assistant.

$\mathrm{He}$ is unmarried.

Patton has been manager of the Parker \& Patton Apple Orchards, Asheville, N. C., since November I, I9II. He was in the employ of the United States Forest Service as forest assistant from July, 1908, to December, 1909, and from January, I9IO, to September, I9II, as deputy forest supervisor.

$\mathrm{He}$ is a member of the Episcopal church.

\section{Rutledge Parker}

Business address, Missoula National Forest, Missoula, Mont.

Residence, 50r Stephens Avenue, Missoula, Mont.

Rutledge Parker was born September 19, 1877, in Georgetown County, S. C., the son of Rutledge Parker and Charlotte Meade (Huger) Parker. $\mathrm{He}$ is the grandson of Dr. Francis S. Parker and Mary (Taylor) Parker. He has a brother, Dr. John E. Parker, B.S. Union College 'or and M.D. Yale '06, and two sisters: Mrs. John Cheston Morris and Mariamnie Meade Parker.

He graduated from the Porter Military Academy of Charleston, S. C., in 1897 and from that time until January, 1898 , worked in the cotton business in Charleston. From 1898 to 1900 he planted rice near Georgetown, S. C., and from 1900 to 1905 was employed by the Atlantic Coast Lumber Company.

He was married July 25, 1910, in Elk Horn Ranch, Granite County, Mont., to Miss Albertina Brown of Philipsburg, Mont., daughter of Frank Dean Brown and Anna Elizabeth (Lenz) Brown.

Parker writes: "I entered the Yale Forest School July 5, I905, and remained until the following spring, taking the Junior course. I spent the summer vacation of 1906 in the mountains of North Carolina near Asheville recuperating from the strenuous duties at the School. My health was not particularly good at that time so thought it unwise to return to the School the following year. Through the influence and sincere efforts of $\mathrm{Mr}$. Henry S. Graves I received an appointment as forest guard on 
the Coconino Forest in Arizona. There were a large number of timber sales on the Forest at that time and my work was all along that line. After spending a year in this region I returned to the School in October, 1907, and completed the Senior course. I took the civil service examinations at Silicanzo, Ala., with my Class of 1908, during the spring term of the Senior year. At that time we were studying lumbering conditions of the Kane Lumber Company's holdings. After completing the spring term I returned to Charleston, S. C., shortly afterwards received an appointment as forest assistant and reported to Washington, D. C., July I, 1908. I left on the same day for Thompson Falls, Mont., and joined a reconnaissance party on the Cabinet National Forest. Our work was principally along the line of timber estimates, together with a general land classification of odd sections included within the primary limits of the Northern Pacific Railroad grant. On November 18, 1908, I was assigned to the Coeur d'Alene National Forest as forest assistant. On July 20, I909, was transferred to the Kootenai National Forest and a few months afterwards was appointed as deputy forest supervisor. During March of I9II I was again transferred to the Missoula National Forest as acting forest supervisor, with headquarters at Missoula, Mont. On July I, I912, received an appointment as forest supervisor."

$\mathrm{He}$ is a member of the Episcopal church. He served at one time in the militia of the State of South Carolina, later in the Territory of Arizona as first sergeant and in Montana as first lieutenant.

\section{Non Graduates}

\section{*Burgess Dickinson}

\section{Died 1913}

Burgess Dickinson was born December 5, 1884, in Knoxboro, N. Y., the son of Rev. Edwin Henry Dickinson, D.D., B.A. Amherst '79, a Presbyterian clergyman, and Emma (Carter) Dickinson. $\mathrm{He}$ had two brothers, one a graduate of Hamilton in 1905, and a sister. An uncle, Walter Frederick Carter, was graduated at Yale in 1895.

During his boyhood his home was successively in McGrawville, Seneca Falls, and Buffalo, N. Y., and he was prepared for college at the Master 
Park High School, Buffalo. He received the degree of $\mathrm{Ph.B}$. at Yale in 1907 and attended the Yale Forest School in 1906-07 and 1907-08.

$\mathrm{He}$ was unmarried.

After leaving the Yale Forest School Dickinson became an engineer for the Edison Company in New York City. Recently he had decided to devote himself to the study of music, for which he had unusual gifts.

He had been in ill health for some time, and died suddenly in New York City, January 28, r9I3. He was a member of the North Presbyterian Church in Buffalo.

\section{George E. Gage}

Business address, Amherst, Mass.

Home address, Springfield, Mass.

George Edward Gage was born December 31, 1883, in Springfield, Mass., the son of William N. Gage, who was born in Haverhill, Mass., and Mary Elizabeth (Lashorn) Gage. He has two sisters: Mary Elizabeth and Ethel Gertrude Gage, and a brother, Charles Alexander Gage.

He was prepared at the Springfield (Mass.) High School and before entering Yale attended Clark University, Worcester, Mass., studying in the collegiate department. In 1906, having completed the summer work in the Forest School at Milford, $\mathrm{Pa}$., he did some work in the Yale Forest School. In 1907 he received the degree of M.A. and in Ig09 the degree of Ph.D. from Yale, his specialty being bacteriology and physiological chemistry.

He is unmarried.

Since September I, I9II, Gage has been assistant professor of animal pathology at the Massachusetts Agricultural College, Amherst, Mass.

He has published articles on bacteriology, comparative pathology and sanitation in scientific and popular scientific journals.

\section{Walter W. Gleason}

Business and residence address, Munising, Mich.

Johnsonburg, $\mathrm{Pa}$.

Walter William Gleason was born June I8, I886, in Ridgway, Pa., the son of William Stone Gleason, postmaster at Johnsonburg, $\mathrm{Pa}$., for sixteen years, and Minnie Warner (Service) Gleason. He is the grandson on his father's side of William Brown Gleason and Caroline (Stone) 
Gleason and the great-grandson of William Gleason, son of Joseph Gleason, son of Abner Gleason. On his mother's side he is the grandson of Walter Scott Service and Mary (Warner) Service and the great grandson of Robert S. Service.

He was prepared at the Johnsonburg High School, Johnsonburg, Pa., and in 1906 received the degree of B.S. at Allegheny College, Meadville, Pa., where he was a member of Phi Kappa Psi.

He was married September 14, 1909, in Harrisburg, Pa., to Miss Dorothy Travis Coleman of Scotland, $\mathrm{Pa}$., daughter of Alfred Coleman and Jean (Lias) Coleman. They have one daughter, Meribah Coleman Gleason, born October 10, 1911, in Munising, Mich.

Gleason was at one time appraiser for the United States Leather Company of New York City. He then became forester for the New York and Pennsylvania Pulp \& Paper Company of New York City, then forester and woods superintendent for the A. Sherman Lumber Company and the Racquette River Paper Company of Potsdam, N. Y., and later, assistant director of Wyman's School of the Woods, Munising, Mich. Since June I5, I9II, he has been professor of logging and engineering at Wyman's School of the Woods. He is also city engineer of Munising, Mich., deputy county surveyor of Alger County, Michigan, and a partner in Wyman, Gleason \& Company, foresters, surveyors and nurserymen of Munising, Mich.

He attends the Episcopal church. In politics he is a Republican. He is a member of Elk Lodge, 379, Free and Accepted Masons, and of St. Lawrence Chapter, 24, Royal Arch Masons.

He has written: Surveying-estimating, Manual of Michigan Forest Scouts.

\section{James E. Martin}

Business address, United States Forest Service, Leadville, Colo. Residence, Vendome Hotel, Leadville, Colo.

James Edward Martin was born June 6, 1883, in Brockton, Mass., the son of Patrick Martin and Margaret Ann (O'Brien) Martin. He is of Irish ancestry. He has three brothers: John F. Martin, William H. Martin and Joseph Martin; and two sisters: Rose A. Martin and Alice Martin, a graduate of the State Normal School, Bridgewater, Mass.

He was prepared at the Brockton High School, Brockton, Mass., and in 1906 received the degree of B.S. from the Massachusetts Agricultural College, where he was a member of C.S.C.

$\mathrm{He}$ is unmarried. 
In the summer of 1907 Martin was city forester of Plainfield, N. J. After leaving the Yale Forest School in 1907 he went to Harvard, where he received the degree of M.F. in 1908. Since July I, I908, he has held the position of forest assistant in the United States Forest Service with headquarters in Leadville National Forest, Colorado.

$\mathrm{He}$ is a member of the Roman Catholic church.

\section{Wilfred E. Murchie}

\section{Business address, 80 Broad Street, New York City}

Residence, II2I Bedford Avenue, Brooklyn, N. Y.

Wilfred Eaton Murchie was born June 23, 1885, in South Orange, N. J., the son of Horace Beverly Murchie and Annie Kimball (Eaton) Murchie. His father is head of the H. B. Murchie Company, lumber dealers. He is of Scotch and English ancestry. He has a brother, Howard Murchie, and a sister, Lillian Murchie.

He was prepared at the South Orange High School, South Orange, N. J., and at Phillips Andover and in 1907 graduated from the Sheffield Scientific School at Yale, where he was a member of Phi Beta Kappa.

$\mathrm{He}$ is unmarried.

After completing the course at the Yale Forest School, Murchie was employed in the Bailey \& Alling Lumber Company of Newark, N. J., and later with the Cross, Austin \& Ireland Lumber Company of Brooklyn, N. Y. Since February I, I912, he has been secretary and treasurer of Shillito \& Murchie, Inc.

$\mathrm{He}$ is a member of the Yale Club of New York City.

\section{Royal F. Nash}

Grand Rapids, Wis.

Royal Freeman Nash was born February 22, 1885, in Grand Rapids, Wis., the son of Thomas E. Nash and Ella Maria (Hussy) Nash, daughter of a Universalist preacher. His father has held the positions of superintendent of the Railway Mail Service, member of the Wisconsin Assembly, director in the Wood County National Bank, president and general manager of the Nekoosa Paper Company, president of the Nash Lumber Company and president of the Nekoosa-Edwards Paper Company. His father's ancestors were Irish immigrants and his mother's family originally settled in New England. He has two sisters: Mrs. William 
A. Scott, B.A. University of Wisconsin, and Mrs. Mason C. Bramham; and three brothers: Guy Nash, B.S. University of Wisconsin, James B. Nash, B.S. University of Wisconsin, and Leo Nash, B.A. University of Wisconsin.

He was prepared at the Grand Rapids High School, attended the universities of California and Wisconsin, and in 1908 received the degree of B.S. from Columbia University.

$\mathrm{He}$ is unmarried.

Nash has served as forester in the Philippine Bureau of Forestry.

He is a Socialist.

\section{Herbert S. Nelson}

Business address, Box 37, New London, Conn.

Home address, 758 Savin Avenue, West Haven, Conn.

Herbert Stuart Nelson was born January. 17, 1885, in New Haven, Conn., the son of James Andrew Nelson, a traveling salesman for Price \& Lee Company, and Martha (Walker) Nelson.

He was prepared at the Hillhouse High School, New Haven, Conn., and in 1905 graduated from the Sheffield Scientific School at Yale.

$\mathrm{He}$ is unmarried.

Nelson is a civil engineer for the New York, New Haven \& Hartford Railroad, which position he has held since October, I9I I. He writes: "From August I, I905, until January 5, I906, I was employed by the Hartford \& Springfield Street Railway Company as rodman and draftsman. During this time I resided at Windsor Locks, Conn., often taking trips into Massachusetts and down to New Haven. I was next connected with the Lackawanna Railroad from February I, I906, to October I0, I906, where I was employed as face account man on the construction of their Bergen Hill Tunnel under Jersey City. I resided during this time in Paterson, N. J. Before going to Lackawanna, I took a trip through New Jersey and down to Washington, D. C. While with this railroad I frequently ran up to New Haven and made numerous trips through New Jersey; also visited Buffalo and Niagara Falls. On leaving the Lackawanna I entered the Yale Forest School, completed one year and spent the summer at the camp at Milford, Pa. From September I9. 
I907, to October I, I908, I was in New Haven. On October 26, I908, I went to Nevada and worked for two years in the Quartette Mine at Searchlight, both mine and cyanide mill. Came home for a visit in 1910 and then went back to Nevada, where I was employed in the construction of a new layout on the San Pedro, Los Angeles \& Salt Lake Railroad during the year. In the fall of I9I I came home again, going to work for the New York, New Haven \& Hartford Railroad. I also spent some time in California, Nebraska and Utah."

$\mathrm{He}$ is a member of the Congregational church. He is a member of the Young Men's Republican Club of New Haven and is a Mason.

\section{Aretas A. Saunders}

Business address, United States Forest Service, Chouteau, Mont. Home address, 40 Crary Avenue, Mt. Vernon, N. Y.

Aretas Andrews Saunders was born November 15, 1884, in Avon, Conn., the son of George Augustus Saunders, Yale '79 S., a business man, and Isabel Tyler (Andrews) Saunders. On his father's side he is the descendant of early English settlers in and about Newport, R. I., and on his mother's of English settlers in northern Connecticut. $\mathrm{He}$ has two sisters: Winifred Andrews Saunders (Mrs. Donald B. McLane), B.A. Mount Holyoke '05, and Dorothea Saunders (Mrs. Thomas B. Powell).

He was prepared at the Boardman Manual Training School, New Haven, Conn., and in 1907 graduated from the Sheffield Scientific School at Yale, where he was on the $1906 \mathrm{~S}$. and $1907 \mathrm{~S}$. Swimming teams and won the plunge at the Y. M. C. A. meet in 1905 .

His engagement has been announced.

Saunders is forest assistant in the United States Forest Service with headquarters in the Lewis and Clark National Forest, Chouteau, Mont., which position he has held since June, I9II. From July, Ig08, to August, I909, he was assigned as forest assistant to Gallatin National Forest, Bozeman, Mont.; from August, I909, to October, I909, to Deerlodge National Forest, Anaconda, Mont.; from October, I909, to January, I9Io, to Sioux National Forest, Camp Crook, S. Dak. ; and from January, I9I0, to June, I9I I, to Deerlodge National Forest. He writes: "It was in March, I908, that I left old New Haven to take my last 
term's work in the pine woods of Alabama. After three months in the South, during which I tremblingly tackled the civil service examinations, I found myself at Washington, D. C., ready to start work with the United States Forest Service. My fate was soon dealt out and I was shipped to Bozeman, Mont. Here I remained a year and learned to master the wiles of a saddle horse and acquired a few other accomplishments. In August, I909, I was transferred to Anaconda, Mont., and in June, I9II, to Chouteau, Mont., which still remains my headquarters. Since graduation I have come East once for a visit in December, 1909."

$\mathrm{He}$ is a member of the Presbyterian church. Concerning politics he writes: "Am independent of party, but opinions and sympathies at present with those of the Progressive Party." $\mathrm{He}$ is a member of the Cooper Ornithological Club of California and an associate of the American Ornithologists Union.

He has published: Some birds of central Alabama, The Auk, Oct., 1908; A preliminary list of the birds of Gallatin County, Montana, The Auk, Jan., I9I1; Bird notes from southwestern Montana, The Condor, Nov., 19I0, illus.; A study of the nesting of the cedar waxwing, The Auk, July, I9II; Some birds of southwestern Montana, The Condor, Jan., I912.

\section{John A. Sweigert}

\section{Plattsburg, N. Y.}

John Addison Sweigert was born October 4, I884, in Holtwood, Pa., the son of B. L. Sweigert and Mary Elizabeth (Clark) Sweigert.

He was prepared at the Lancaster High School, Lancaster, $\mathrm{Pa}$.

He is unmarried.

Sweigert is assistant forester for the Delaware \& Hudson Railroad. He has held this position since November II, 1912.

\section{Dean S. Tiffany}

Hop Bottom, $\mathrm{Pa}$.

Dean Stanley Tiffany was born in 1883 in Dimoch, $\mathrm{Pa}$. $\mathrm{He}$ was prepared at Keystone Academy and received the degree of B.S. at Keuka College, Keuka Park, N. Y., in 1905. He attended 
the Yale Forest School in 1906-07 and one term in 1907-08, and was also registered for work in the graduate department of the Sheffield Scientific School. He has not furnished any information for this record.

\section{Ralph B. Wainwright}

Residence, 63 Curtis Street, New Britain, Conn.

Ralph Bickerton Wainwright was born June 3, I883, in New Britain, Conn., the son of Charles Patterson Wainwright, a selectman, director of the Savings \& Loan Association and a foreman for the Stanley Works, and Ella May (Bickerton) Wainwright. His father's ancestors came to this country from England in 1690 and his mother's about 1750 . He has two sisters: Elizabeth Wainwright and Grace Wainwright and one brother, Halsted Wainwright. A relative, H. E. Hart, graduated from the Sheffield Scientific School at Yale in 1894.

He was prepared at the New Britain High School and in 1907 graduated from the Sheffield Scientific School at Yale, where he played on the Foresters' Football Team his Junior year.

$\mathrm{He}$ is unmarried.

Since July I, I909, Wainwright has been superintendent of Walnut Hill Park in New Britain, Conn. After leaving the Yale Forest School he was assistant to the head gardener of the Hartford public parks and later did private landscape work. During the winter of I908-09 he worked in a factory and in the spring again entered upon private landscape work, which he continued until his present appointment. He writes: "Am waking up the city to the needs of caring for her trees and have had fine success so far."

$\mathrm{He}$ is a member of the Eastern Branch of the American Association of Park Superintendents.

He has published: Making the home grounds attractive, New Britain (Conn.) Herald, March, I9I I; and Parks in New Britain, New Britain Herald, March, I912. 


\section{CLASS OF 1909 \\ Graduates holding Degree of M.F.}

\section{F. F. Woods Beckman}

\section{Finspong, Sweden}

Fredrik Ferdinand Woods Beckman was born March 26, 1886 , in Stockholm, Sweden, the son of Ernst Johan Beckman, an editor, author and poet and member of the Swedish Senate, and Louise Woods (Baker) Beckman of Princeton, N. Y. His father has for many years been a member of the Swedish parliament, is a member of the Interparliamentary Union and its Council and Executive Committee, city counselor of Stockholm and a member of the School Board. His grandfather on his father's side was a bishop in the Lutheran Swedish (State) Church and professor at the University of Upsala, and his grandmother was daughter of a professor at Upsala. On his mother's side he is the grandson of I. Woods Baker, a chemical civil engineer of the United States Coast Survey, and Sarah S. Tuthill of New Haven, Conn., an authoress and daughter of Cornelius L. Tuthill and Loisa C. Hughins. He has six brothers and sisters: Anna Sturge of London, England; Albert Woods Beckman of Altoona, $\mathrm{Pa}$; John Woods Beckman, a graduate of the Royal Technical Institute of Stockholm and civil engineer at Niagara Falls; Loulette Harding of London, England; Astri Woods Beckman of Djursholm, Sweden; and Robert Woods Beckman, a student at the University of London, England.

He was prepared at school in Djursholm and graduated at Stockholms hõgre Reallãroverk, Stockholm, Sweden, in 1905. Before entering the Yale Forest School he traveled extensively: in 1900 in Norway, IgoI in England and Portugal, 1903 in England, I905 in Norway, Germany, Austria, Hungary and Italy, 1906 in Germany, Switzerland and France, 1907 in Germany, England and the United States.

He was married October 19, 1910, in Rheydt, Germany, to Miss Frieda Dilthey of Rheydt, Rheinland, Prussia, daughter of Gustav Dilthey and Clara (Fischer) Dilthey. They have a son, Gunnar Ernst Gustav Dilthey Woods Beckman, born November 26, I911, in Finspong, Sweden.

Beckman is assistant forester for the firm Aktiebolaget Finspong Styckebruk of Finspong, Sweden, which position he has held since July 24, I9II. Previous to this he was assistant to the forester of the "Norrlandsbanken" in Stockholm, where his work consisted of estimating, mapping and making working plans. 
In I909 he traveled in Germany, and in I9ro in Germany, Austria and Italy.

$\mathrm{He}$ is a member of the Swedish State Church and in politics is a Liberal and a Prohibitionist. He has served in the. Swedish Field Artillery, Svea artilleri-regemente. He is a member of the Liberal Union of Sweden, the Local Liberal Union, the Swedish Forestry Association, the Forestry Association of Sõdermanland och Oestergõtland, the Swedish Touring Club, the National Society against Emigration, and the Swedish "Men's League for Woman's Suffrage." At Yale he was a member of Sigma Xi.

\title{
Frederick H. Billard
}

\author{
Business address, Berlin, N. H. \\ Home address, Meriden, Conn.
}

Frederick Howell Billard was born October 18, 1873, in Meriden, Conn., the son of John Leander Billard, a coal merchant and financier, and Harriet Yale (Merriman) Billard. He had two brothers and one sister: H. M. Billard, Walter S. Billard, Yale ' 93 S., and Mary Billard, all deceased.

He was prepared at St. Paul's School, Concord, N. H., and graduated from Yale in 1896, where he was a member of the Academic Freshman Crew in the fall of 1892 , of the Sophomore Fall and Spring crews and of the Junior Fall Crew.

$\mathrm{He}$ is unmarried.

Billard is secretary, treasurer and forester of the New Hampshire Timberland Owners' Association, which position he has held since January I, I9II. Before entering the Forest School he was employed for a few years in Chicago by Swift \& Company, the packers, after which he returned to Meriden and was a clerk for Lyon \& Billard, coal and lumber dealers.

\section{John M. Briscoe}

Business address, Orono, Maine Home address, The Colonial, Bangor, Maine

John Manvers Briscoe was born July 22, 1878 , in Pottsville, Pá., the son of Sidney Bernard Briscoe, director of the Safe Deposit Bank of Pottsville, Pa., and receiver of the Pottsville Steel Company, and Sarah (Loeser) Briscoe. On his father's side he is the grandson of Robert 
Briscoe and on his mother's side of Christopher Loeser and Louisa Augusta (Bartle) Loeser. He has two sisters: Louise Briscoe and Avalon Briscoe.

He was prepared at the Pottsville High School, Pottsville, $\mathrm{Pa}$., and attended the Massachusetts Institute of Technology and the University of Pennsylvania. Before entering the Yale Forest School he was a member of the engineering corps of the Philadelphia and Reading Coal \& Iron Company and a merchant.

He was married June 28, I911, in Bryn Mawr, Pa., to Miss Ethel Lydia Griscom of Bryn Mawr, daughter of William Morris Griscom and Anna Lydia (Miller) Griscom. They have a son, Sidney Griscom Briscoe, born May 7, 1912, in Brewer, Maine.

In I909- ro Briscoe was forest assistant in the United States Forest Service. Since September I, I9I0, he has been professor of forestry at the University of Maine and public instructor in forestry for the State of Maine. He spent the summer of rgri in a trip of inspection and study of forest regions of the West, visiting each forestry district with the exception of districts I and 4 .

$\mathrm{He}$ is a member of the Episcopal church.

He has published: Article on Forestry Department of University of Maine, Am. For.; numerous articles on forestry subjects in the Lewiston Journal and Bangor Commercial; address before Dominion Forestry Convention, Quebec, I9II; (with R. Zon) Eucalyptus in Florida, Bull. 87 , U. S. Forest Service.

\section{Georges deS. Canavarro}

United States Forest Service, Washington, D. C.

Georges deS. Canavarro was born January 9, 1885, in Honolulu, Hawaii, the son of Antonio deS. Canavarro and Miranda (McElroy) deS. Canavarro. His father was captain of the Royal Navy, minister to the Kingdom of Hawaii, and also consul general of the Territory of Hawaii from 1883 to 1913. His father was from Oporto, North Portugal, and his mother from Kentucky, of Scotch descent.

He spent one year at Cornell and in 1908 received the degree of B.S. from the University of Minnesota. At college he was a member of Sigma Xi, Alpha Zeta and Delta Upsilon.

$\mathrm{He}$ is unmarried.

Canavarro is forest assistant in the United States Forest Service with headquarters at Washington, D. C. He entered 
upon this position March 21, I9I0. In 1912 he spent several months on a vacation at his home in the Hawaiian Islands. $\mathrm{He}$ returned in September and is in charge of the section of compilation in the Washington office.

\section{William D. Clark}

\section{North Prospect Street, Amherst, Mass.}

William Darrow Clark was born May 27, 1877, in Rahway, N. J., the son of Charles H. Clark, a real estate dealer, and Harriett N. (Crowell) Clark. He is of English descent. He has one brother, Charles H. Clark, and four sisters: Anne Dayton Clark, Cornelia Remsen Clark, Florence La Grange Clark and Elizabeth Darrow Clark.

He was prepared at Phillips Andover, and graduated from Yale College in 1904, where he was a member of the Freshman Glee Club.

He was married March 28, 1912, in Ridley Park, Pa., to Miss Emma A. McFeely of Chestertown, Md., daughter of William James McFeely and Julia M. (Cunningham) McFeely.

Before entering the Forest School, Clark spent two years traveling commercially and four months as student assistant in the United States Forest Service. Between Junior and Senior years in the School he was a forest agent in the Service for eight months. In September, I909, he became assistant professor of forestry in the Pennsylvania State College at State College, $\mathrm{Pa}$. He is now professor of forestry in the Massachusetts Agricultural College at Amherst, Mass. He entered upon his present position in September, I9I2.

He is a Presbyterian.

\section{John D. Coffman}

United States Forest Service, Weaverville, Trinity County, Calif.

John Daniel Coffman was born May Io, I882, in Allentown, Pa., the son of Wilmer Coffman, B.A. Dickinson College, Carlisle, Pa., and a member of Phi Beta Kappa (died in 1908), and Anna Margaret (Evans) Coffman. His father was a clergyman and a member of the Philadelphia Methodist Episcopal Conference for forty years, retiring from the ministry in 1904. He is the grandson on his father's side of Daniel Coffman, a farmer in Chester County, $\mathrm{Pa}$., and Margaret (Patrick) Coffman, and on his mother's side of John Evans and Mary Isabella (Horn) Evans of Easton, $\mathrm{Pa}$. His mother graduated from the State Normal School 
of Millersville, Pa. He has two sisters: Grace Lydia (Coffman) Roxby and Edith James (Coffman) Baker, both graduates of the Philadelphia Girls Normal School, and two brothers: Wilmer Evans Coffman, B.A. Wesleyan University '95 and B.D. Drew Theological Seminary, and Herbert Coffman, B.S. University of Pennsylvania.

He was prepared at the Central High School, Philadelphia, Pa., and was employed by the Alpha Portland Cement Company, Easton, $\mathrm{Pa}$., from the fall of 1900 to September, I905, when he entered the College of Arts and Sciences, Cornell University. He remained at college until 1907 and was a member of Acacia Fraternity.

$\mathrm{He}$ is unmarried.

Coffman entered the United States Forest Service in July, I909, as forest assistant in Inyo National Forest, California. In April, I9ro, he was transferred to Shasta National Forest and in June, I9II, was appointed deputy forest supervisor of Trinity National Forest, California, his present position.

$\mathrm{He}$ is a member of the Congregational church and in politics is a Progressive Republican. He is a member of Sigma Xi, Yale Chapter, and of the Society of American Foresters. He is also a member of Easton Lodge, 152, Free and Accepted Masons, and Easton Royal Arch Chapter, 173, Easton, Pa., of Hugh de Payens Commandery, 19, Knights Templar, Easton, Pa., and of Pyramid Temple, A. A. O. N. Mystic Shrine, Bridgeport, Conn.

\section{Arthur W. DuBois}

Hallstead, $\mathrm{Pa}$.

Arthur Wood DuBois was born February 12, 1886, in Washington, D. C., the son of James Taylor DuBois, Envoy Extraordinary and Minister Plenipotentiary to Columbia and director of several banks, and Emma (Pastor) DuBois. On his mother's side he is of French and German ancestry. He has a brother, Henry Pastor DuBois, M.E. Cornell 'o7.

He was prepared at the Friends' Select School, Washington, D. C., at the Binghamton High School, Binghamton, N. Y., and at Schmidt's Institute, St. Gall, Switzerland, and in 1907 received the degree of B.A. from Cornell University, where he served as a cadet. From this time until he entered the Yale Forest School he was engaged in farming, ranching and traveling.

He was married September 21, 1912, in Hallstead, Pa., to Miss Rena B. Merrell, daughter of Albert F. Merrell and Charlotte Stockholm Merrell. 
DuBois has been engaged in farming in Hallstead, Pa., since June I5, I9I2. Previous to this he was secretary to the American minister at Bogotá, Colombia. He has traveled in Europe, Asia (including Persia, Arabia and Turkestan), northern Africa, Mexico, the West and East Indies and Colombia. In I9I I he served for a short time in the Mexican Revolution.

He has published two stories on Persia in The World To-day, a political article on Persia in the New York Times (Sunday Magazine) and other newspaper articles.

\author{
Herman E. Fegley \\ Business address, Pottsville, $\mathrm{Pa}$. \\ Home address, Auburn, Pa. \\ 508 Laurel Street, Pottsville, Pa.
}

Herman Edgar Fegley was born April 23, 1880, in Drehersville, Pa., the son of Manden S. Fegley, steward of the County Almshouse in I8991900 and a retired farmer, and Mary Ann (Kershner) Fegley. He is the grandson on his father's side of William Fegley and Catherine (Schmick) Fegley and on his mother's side of William Kershner and Elizabeth (Seltzer) Kershner. He has a brother, Clinton L. Fegley, and a sister, Bessie E. (Fegley) Scharadin. Another brother, William L. Fegley, is deceased.

He graduated from Keystone State Normal School, Kutztown, Pa., in 1900 and in 1904 received the degree of B.A. from Franklin and Marshall College. He taught in the high school at McEwensville, $\mathrm{Pa}$, for two terms and part of a term at Conemaugh, $\mathrm{Pa}$. He then received a civil service appointment in the Government Printing Office, Washington, D. C.

$\mathrm{He}$ is unmarried.

Since October, I9II, Fegley has been manager and partner in the Acme Knitting Company, manufacturers of ladies' underwear, of Pottsville, $\mathrm{Pa}$. He writes: "Entered the United States Forest Service July I, I909, and remained there a year and a half. During the summer of 1909 I was engaged in estimating timber in the Rocky Mountains on the Helena and Gallatin National forests. I was then appointed forest assistant on the Sioux National Forest, South Dakota."

$\mathrm{He}$ is a member of the Reformed church and in politics is a Progressive Republican. He was a charter member of Acacia 
Fraternity at Yale and belongs to the Order of Independent Americans and to Schuylkill Lodge, I38, Free and Accepted Masons, of Orwigsburg, $\mathrm{Pa}$.

\section{Frederick A. Gaylord}

Business address, Conservation Commission, Albany, N. Y. Residence, 26 Lancaster Street, Albany, N. Y.

69 South Cliff Street, Ansonia, Conn.

Frederick Alan Gaylord was born June I, 1885, in Ansonia, Conn., the son of Frederick Littlefield Gaylord, postmaster at Ansonia for ten years and the member of longest service on the Republican State Control Committee, and Mary Emma (Peck) Gaylord. He is the grandson on his father's side of Miles Allen Gaylord, and on his mother's side is a direct descendant of Elihu Yale. He has one brother, Harold B. Gaylord, M.E. Stevens Institute '04.

He was prepared at the Boardman Manual Training High School, New Haven, Conn., at Stevens Institute, Hoboken, N. J., and at Dean Academy, Franklin, Mass. In 1908 he graduated from the Sheffield Scientific School at Yale, where he received honors in his Freshman and Junior years. He was a member of Beta Theta Pi at Stevens Institute.

$\mathrm{He}$ is unmarried.

Gaylord is state forester of New York State. He received this appointment December 6, I910. He writes: "Entered the United States Forest Service July I, 1909. Spent most of my time while in the Service on the Northern Pacific estimates and general reconnaissance work in western Montana, the panhandle of Idaho and eastern Washington. Became connected with the Department of Forestry at the Michigan Agricultural College, July I5, I9I0. On December 6, I9IO, I accepted a position with the Forest, Fish and Game Commission of Albany, N. Y. This commission was later legislated into the Conservation Commission. My work in New York consisted of all kinds, from practical to educational. In March, I912, I received an offer to have charge of the Syracuse Ranger School of Syracuse University. Refused offer carrying increase of 900 per annum."

In politics he is "Independent, with strong Progressive tendencies." He is a member of the American Society of Foresters and the University Club of Albany. 
He has published: Penal labor and conservation, Am. For., Feb., 1912; Are there too many forest schools? Am. For., June, I912; Shade trees, Bull., N. Y. Conservation Com., I912; Forestry and forest resources, Bull., N. Y. Conservation Com., I912.

\section{Belknap C. Goldsmith}

United States Forest Service, Alturas, Calif.

Belknap Chittenden Goldsmith was born November 25, 1882, in New York City, the son of Jay Charlton Goldsmith, for many years editor of the New York Herald, and Alice (Westervelt) Goldsmith. He is the grandson on his father's side of William Belknap Goldsmith and Helen (Hammond) Goldsmith, and on his mother's side of Ralph Westervelt and Cornelia (Campbell) Westervelt. He has two brothers: Paul Goldsmith and Goldwin Goldsmith, who received a degree in architecture from Columbia University in 1896.

He was prepared at Oakland High School, Oakland, Calif., and in 1906 received the degree of B.S. from the University of California.

He was married June 19, I912, in Alturas, Calif., to Miss Marion Sarah Hawkes of Alturas, daughter of Albert A. Hawkes and Cora Bell (Warren) Hawkes. They have a son, born April 25, 19I3, in Alturas, Calif.

Upon graduation from the Yale Forest School Goldsmith entered the United States Forest Service as forest assistant. He is at present forest assistant on Modoc National Forest, Alturas, Calif.

$\mathrm{He}$ is a member of the First Congregational Church of Oakland, Calif., and belongs to the Society of American Foresters.

\section{Edgar C. Hirst}

Concord, N.H.

Edgar Clarkson Hirst was born August 30, 1882, in Yellow Springs, Ohio, the son of John Janney Hirst, a druggist (deceased), and Mary (Bowe) Hirst. His father was educated at Antioch College under Horace Mann. He is a descendant of John Hirst, a Presbyterian minister, who came from Yorkshire, England, to Philadelphia in 1737 and whose descendants married into Philadelphia Friends families. He is the grandson on his mother's side of Erastus Bowe of Rutland, Vt., a pioneer in northwestern Ohio, paymaster in the War of $18 \mathrm{r} 2$ and a member of a small detachment which built and held Fort Stephenson against British and Indian attacks. 
He was prepared at Yellow Springs High School and at the Preparatory School of Antioch College. In 1907 he received the degree of B.A. from Ohio State University, where he was a member of Delta Upsilon.

$\mathrm{He}$ is unmarried.

Since July I, I909, Hirst has held the position of state forester of New Hampshire.

$\mathrm{He}$ is a member of the Unitarian church. Concerning politics he writes: "Have always been a Republican. Believe in progressive principles and increasing the power of the national government." At Yale he was a member of Sigma Xi. He is a Blue Lodge Mason.

\section{Oswald D. Ingall}

99 South Fullerton Avenue, Montclair, N.J.

Oswald Drew Ingall was born September 10, 1884, in Sault Sainte Marie, Ontario, Canada, the son of Elfric Drew Ingall, for thirty years a geologist in the Canadian Geological Survey, and Blanche (Plummer) Ingall. On his father's side he is the great-grandson of W. T. F. M. Ingall of Greenhithe, Kent, England, and Joan Drew of Ireland. On his mother's side he is of English ancestry. He has two half brothers and two half sisters.

He was prepared at the Ottawa Collegiate Institute and Montclair High School and in $\mathbf{1 9 0 3}$ entered Cornell University in the forestry course. When the Forest School was discontinued, he entered the College of Arts and Sciences at Cornell and received the degree of B.A. in 1907. At college he was a member of Bandhu.

$\mathrm{He}$ is unmarried.

From I909 to I9I I Ingall was forest agent in the United States Forest Service. He then became forest assistant and later entered the British Columbia Forest Service under H. R. MacMillan of the Class of Igo8. He has recently left the Canadian Service and is with relatives in Montclair, N. J. He expects to remain in the East. He writes: "Worked on third Kentucky report during the summer of 1909 , on the Illinois report in the winter and spring of I9Io and on the Pittsburgh Flood Commission Report in the winter of I9IO. In the spring of I9I I went on a trip to California. Worked on examination of land in Georgia in the spring of I9II, in Nantahala Area in the summer and fall of I912." 
$\mathrm{He}$ is a member of the Cornell University Club, New York, and is a Mason.

He has published: (With R. C. Hall) Report on forest conditions in Illinois, Ill. Dept. Natural History.

\section{Henry L. Johnson}

54 Broadway Extension, Boston, Mass.

Henry Langley Johnson was born November 30 , 1882, in Boston, Mass., the son of Henry Franklin Johnson, a Civil War veteran, and Ella Sands (Langley) Johnson. His father was born in Barre, Vt., the son of George S. Johnson and Fidelia (Freeman) Johnson. His mother was born in Biddeford, Maine, the daughter of Samuel T. Langley and Elizabeth (Sands) Langley.

He was prepared at the English High School, Boston, Mass., and at Ithaca High School, Ithaca, N. Y. In 1907 he received the degree of B.A. from Cornell University.

$\mathrm{He}$ is unmarried.

In October, I908, Johnson and C. A. Metzger of Hartford, Conn., established the Mount Carmel Forestry \& Nursery Company. From July I, I909, to October 20, I9I2, he was forest assistant in the United States Forest Service. He was granted a leave of absence during this time and from April 5, 1912, to July 19, 1912, was transitman for Fisher, Bryant \& Olmsted, and from September I, I9I2, to October II, I9I2, was with the W. M. Ritter Lumber Company of Mortimer, N. C. He has lately reëntered the Forest Service and has been stationed in the heart of the moonshine region at Blue Ridge, Ga.

In politics he is an Independent and a Freetrader. He is a member of the Massachusetts Forestry Association and the Connecticut Nurserymen's Association.

\section{R. Chapin Jones}

Business address, State Board of Forestry, Baltimore, Md.

Home address, 9 Concord Avenue, Cambridge, Mass.

Richard Chapin Jones was born September 26, I885, in Des Moines, Iowa, the son of Richard Jones, Ph.D. Heidelberg University and a member of Phi Beta Kappa, and Carrie Holmes (Grinnell) Jones. His 
father has been professor of English at Tufts, Vanderbilt, Syracuse and Swarthmore, was at one time on the New York State Board of Regents and is the author of "Growth of the Idylls of the King," etc. On his father's side he is of Welsh ancestry and is the grandson on his mother's side of J. B. Grinnell of Vermont and Julia Ann (Chapin) Grinnell of Massachusetts. He has three brothers: Grinnell Jones, B.S. Vanderbilt University '03, M.S. '05, M.A. Harvard '05, and Ph.D. '08; Eliot Jones, B.A. Vanderbilt ' 06 , and M.A. Harvard ' 08 ; and Percival Jones, and two sisters: Elaine Jones, who graduated from Tufts College, and Beatrice Jones.

He was prepared at Grinnell College Academy, Iowa, and Syracuse High School, Syracuse, N. Y., and in 1904 received the degree of B.A. from Vanderbilt University, where he was a member of Sigma Nu. He did post-graduate work at Vanderbilt two years, with a fellowship in biology one year, and afterward worked for a railroad a year, surveying, etc.

He was married December 26, I912, in North Conway, N. H., to Miss Alice Morrison of North Conway, N. H., daughter of William Hugh Morrison, and Linnie Keene Morrison.

Upon graduation from the Yale Forest School Jones entered the United States Forest Service, where he was employed until June 19, 1910, as forest assistant with headquarters principally in Gallatin and Lolo National forests in Montana and in Kaniksu in Washington. He was then appointed forest assistant for the Pennsylvania Railroad Company, which position he held until January I, I9II. From this time until September I5, I9II, he traveled in the interests of his father in Florida, New England and western Canada. He then took up farming in Massachusetts, but left this on April 15, 1912, to accept a position as field assistant with the New Hampshire State Forestry Commission. On August I, 1912, he was appointed assistant state forester of Maryland, his present position.

In politics he is a Progressive Democrat.

\section{Joseph C. Kircher}

United States Forest Service, Albuquerque, N. Mex.

Joseph Casimir Kircher was born November 15, 1884, in Bellville, Ill., the son of Henry A. Kircher, a hardware merchant of the firm of Kircher \& Son, and Bertha (Engelmann) Kircher (deceased). He is of German descent. He has two brothers: Harry B. Kircher, B.S. 
Illinois '04, and Theodore E. Kircher, Yale '07 S., LL.B. '10. A cousin, Coleman E. Andel, graduated from Yale in 1902.

He was prepared at Smith Academy, St. Louis, Mo., and graduated from Yale College in 1907, where he received a first colloquy Junior appointment, was a member of Beta Theta $\mathrm{Pi}$ and of the University Orchestra.

$\mathrm{He}$ is unmarried.

Kircher entered the United States Forest Service on July I, I909. His first appointment was as forest assistant in the Coconino National Forest. This position he held until June I, I9II, when he was appointed deputy supervisor, his present position.

$\mathrm{He}$ is a member of the Concatenated Order of Hoo-Hoo.

\section{Aldo Leopold}

Business address, Forest Service, Trés Piedras, N. Mex. Home address, Ior Clay Street, Burlington, Iowa

Forest Service, Albuquerque, N. Mex.

Aldo Leopold was born January II, I886, in Burlington, Iowa, the son of Carl Adolph Leopold, manager of the Leopold Desk Company, Burlington, Iowa, and Clara (Starker) Leopold. He is of German descent, both his grandfathers being German university graduates, who came to America and engaged in banking and business. He has one sister, Marie Leopold, a graduate of the Bennett School, and two brothers: Carl Starker Leopold, Yale 'Ir S., and Frederic Leopold.

He was prepared at the Burlington High School and the Lawrenceville (N. J.) School, and graduated from the Sheffield Scientific School in 1908. While at Yale he was a member of the Freshman Union (1905-06), of the Sheff Debating Society (executive committee, I905-07, and secretary and treasurer, 1907-08), and of the executive committee of the Sheff Y. M. C. A. He also had charge of the Yale Extension work for New Yale in China (1907-08).

He was married October 9, 1912, in Santa Fé, N. Mex., to Miss Estella Luna Bergère of Santa Fé, N. Mex., daughter of Mr. and Mrs. Alfred M. Bergère.

Leopold is forest supervisor of the Carson National Forest, in New Mexico. When he entered the Service in July, I909, he was appointed forest assistant in the Apache National Forest. This position he held until April, I9II, when he became deputy 
forest supervisor in the Carson National Forest. For a time he held a position as acting supervisor in District 3 before being appointed to his present position.

$\mathrm{He}$ is a Republican.

\section{Everett H. MacDaniels}

Business address, United States Forest Service, Sumpter, Ore. Home address, 250 East College Street, Oberlin, Ohio United States Forest Service, Beck Building, Portland, Ore.

Everett Herman MacDaniels was born October 3, 1882, in Fremont, Ohio, the son of Herman Nye MacDaniels, lieutenant of Company A, the IIIth Regiment, Ohio Volunteer Infantry, during the Civil War, and Ellen Woodbury (Fay) MacDaniels. His paternal grandfather was born in England and the rest of the family have lived in America since about 1700, for the most part in eastern Massachusetts. His grandfather on his mother's side was a Congregational minister. He has two brothers: Frederick K. MacDaniels, who studied at Ohio State University, and Laurence H. MacDaniels, B.A. Oberlin College; and two sisters: Alice C. (MacDaniels) Fauver, B.A. Oberlin '99, and Anna Woodbury (MacDaniels) Fauver, B.A. Oberlin 'o5.

He was prepared at Oberlin High School and at Oberlin Academy and in 1906 received the degree of B.A. from Oberlin College.

$\mathrm{He}$ is unmarried.

MacDaniels entered the United States Forest Service July I, I909, as forest assistant. In I9IO he was appointed deputy forest supervisor with headquarters on Whitman National Forest, Sumpter, Ore., which position he now holds.

\section{Rufus S. Maddox \\ Quincy, Calif.}

Rufus Sherrell Maddox was born November 19, 1874, in Coldwater, Tenn., the son of James Jefferson Maddox and Martha Ann Taylor (Sherrell) Maddox. On his father's side he is of Scotch-Irish and on his mother's of English ancestry. He has five brothers: John S., Auburn A., Solon J., Herman L., and Lofton Maddox, and two sisters: Bessie Marvin and Mary Stella Maddox.

His youth was spent on a farm with intermittent attendance at public schools until the age of twenty. He taught for a few years in the 
public schools and then went to Winchester Normal College, where he received the degree of B.A. in I900. He graduated from Yale College in 1907, having received scholarships, a prize in Latin and an oration Junior and Senior appointment. His society was Alpha Delta Phi.

He was married January 3, I9I2, in New York City, to Miss Marie Janet Morrow of New York City, daughter of Cornelius Wartendyke Morrow and Rosalie Caroline (Lippmann) Morrow.

Before entering the United States Forest Service Maddox served for a time as a technical forester in private forestry. His present appointment is that of forest assistant, a position he has held since entering the Government Service on February I, I9IO. Concerning his travels, Maddox says: "Since leaving Yale in 1909 my travels have been chiefly in New York State, Pennsylvania, Massachusetts and Connecticut in the East. I have been across the United States three times in connection with my profession and vacations. My experiences have been chiefly business ones in contact with lumbermen and technical men of the Forest Service."

Maddox is a "Democrat, Progressive in spirit." He is a member of the Society of American Foresters.

$\mathrm{He}$ has published an article, Timbersales on the Plumas National Forest, March, 1912.

\section{Frederick F. Moon \\ Syracuse University, Syracuse, N. Y.}

Frederick Franklin Moon was born July 3, I880, in Easton, Pa., the son of William W. Moon, a Quaker, and Ophelia F. (Nightingale) Moon. He has a sister, Emelie N. Miller.

$\mathrm{He}$ was prepared at the Easton High School, Easton, $\mathrm{Pa}$, and in I90I received the degree of B.A. from Amherst, where he was a member of Zeta Psi. He spent two years at the Harvard Medical School and four years in business and contracting work.

He was married June 1, 1912, in New York City, to Miss Pearl Browning Stetson of Columbus, Ohio, daughter of Matthew Wilson Stetson and Mary (Browning) Stetson.

During the summer of 1909 Moon was employed in the United States Forest Service and in 1909-10 held the position of state forester of the Forest, Fish and Game Commission. From Igro to I9I2 he was professor of forestry at the Massachusetts Agri- 
cultural College, Amherst, Mass., and September 1, 1912, he was appointed professor of forest engineering at the New York State College of Forestry, Syracuse University, N. Y., his present position. He spent the summer of 1912 studying forestry practice in Germany, France and Switzerland. Early in the year 1913 he went on a lecture tour in the interests of forestry through the counties of Ontario, Yates and Wayne, New York State. In this series of talks he discussed the possibilities of reforesting the idle lands of the state, the forest conditions of the state in the past and the present, the possibilities of improving the farm woodlot and the utilization of waste portions of the farm by the planting of forest trees.

In politics he is a Republican. He is a member of the Society of American Foresters. He is Secretary of the Class of 1909, Yale Forest School.

He has published: Report on highlands of Hudson Reservation, $N . Y$. Forest, Fish and Game Rep., 1909, and Forest conditions of Warren County, N. Y. Forest, Fish and Game Rep., roro.

\section{William B. Osborne, Jr.}

Business address, 503 Beck Building, Portland, Ore.

Residence, 724 East Main Street, Portland, Ore.

William B. Osborne, Jr., was born November 25, 1884, in Rochester, N. Y., the son of William B. Osborne and Laura Virginia (McDonnald) Osborne. He is the grandson on his father's side of David H. Osborne and Lavinia (Bushnell) Osborne, and on his mother's side of Angus McDonnald and Virginia (Dibble) McDonnald. He has a brother, D. Henry Osborne, B.A. Williams '05 and B.S. Union '07, and two sisters: Elizabeth McDonnald Osborne, B.A. Mount Holyoke 'I2, and Ruth McDonnald Osborne.

He was prepared at the Victor High School, Victor, N. Y., and in 1907 received the degree of B.A. from Williams, where he was a member of Phi Sigma Kappa.

He was married June 2I, I909, in Canandaigua, N. Y., to Miss Lura Esther Cooley of Canandaigua, N. Y., daughter of A. S. Cooley and Harriet Reed Cooley.

Osborne is forest assistant in the United States Forest Service with headquarters in the Oregon National Forest, which position he has held since July I, I909. He writes: "Since leaving Yale 
have been in Forest Service. Work has been principally timber reconnaissance, fire fighting, planting and surveying."

$\mathrm{He}$ is a member of the Presbyterian church and in politics is a Progressive. He is a Mason.

\section{Percy J. Paxton}

Business address, Steamboat Springs, Colo.

Home address, Princeton, Ind.

United States Forest Service, Denver, Colo.

Percy Jerauld Paxton was born June 13, 1884, in Princeton, Ind., the son of Thomas Rice Paxton, born in Shelbyville, Ky., the son of John D. Paxton, D.D., a Presbyterian minister, and Amelia (Jerauld) Paxton, daughter of George N. Jerauld and Nancy (Foster) Jerauld. He has two sisters: Laura Jerauld Paxton, B.A. Smith '02, and Leonora Merrill Paxton, B.A. Smith 'oo.

$\mathrm{He}$ was prepared at Phillips Exeter Academy and in 1906 received the degree of B.A. from Williams College, where he was a member of Delta Kappa Epsilon.

He is unmarried.

Since graduating from the Yale Forest School Paxton has been employed in the United States Forest Service as forest assistant. His headquarters are at present on Routt National Forest, Steamboat Springs, Colo. He has recently been promoted to the rank of forest examiner.

$\mathrm{He}$ is a member of the Presbyterian church.

\section{Reuben P. Prichard \\ Business address, New York State College of Forestry, Syracuse \\ University, Syracuse, N. $Y$. \\ Home address, 16 Fremont Street, Somerville, Mass.}

Reuben Parker Prichard was born February 25, 1884, in Somerville, Mass., the son of George William Prichard and Mary Louisa (Lane) Prichard. On his father's side he is of Welch and on his mother's of Irish ancestry. He has a sister, Emma Elizabeth Prichard, and a brother, John Augustus Prichard.

He was prepared at the Somerville English High School, Somerville, Mass., and in 1907 received the degree of B.S. from Dartmouth College, where he was a member of Kappa Kappa Kappa and the Dragon Society.

$\mathrm{He}$ is unmarried. 
Upon graduation from the Yale Forest School Prichard was appointed forest assistant in the United States Forest Service with headquarters in Missoula National Forest, Montana. In the fall of 1912 he accepted the position of instructor in the Ranger School, New York State College of Forestry, Syracuse, N. Y., his present appointment.

$\mathrm{He}$ is a member of the Congregational church and in politics is a Progressive.

\section{Abbott B. Silva \\ Forest Service, Missoula, Mont.}

Abbott Beecher Silva was born October 4, 1885, in Thomasville, Ga., the son of William Posey Silva, an artist, and Caroline Walker (Beecher) Silva. A relative, Harrison D. Burrall, is ex-'of Forest School.

He was prepared at the Chattanooga High School, Chattanooga, Tenn., and at the Manor School, Sțamford, Conn., and in 1908 graduated from the Sheffield Scientific School at Yale, where he was a member of the Sheff Debating Society and of the Spanish Club.

$\mathrm{He}$ is unmarried.

Silva is forest assistant in the United States Forest Service, with headquarters at Missoula, Mont. He entered the Service July I, I9IO, receiving his present appointment.

\section{Robert Simmons}

Robert Simmons was born in 1885 in New York City. He attended the preparatory and collegiate departments of the College of the City of New York and received the degree of B.A. in 1906.

Simmons entered the United States Forest Service in July, 1909, but resigned in October of the same year. It has not been possible to secure his present address.

\section{Thomas E. Snyder}

Business address, Bureau of Entomology, Washington, D. C.

Home address, 420 West Ir6th Street, New York City

Thomas Elliott Snyder was born February 6, I885, in New York City, the son of Roger Snyder, a physician, and Alice Celinda (Brice) Snyder. On his father's side he is of German ancestry and on his mother's Scotch, 
her ancestors having been engaged in farming for several generations in Monroe County, western New York.

He was prepared at Betts Academy, Stamford, Conn., and at the Horace Mann High School, New York City, and in I907 received the degree of B.A. from Columbia University. In 1897 he started a systematic collection of coleoptera.

$\mathrm{He}$ is unmarried.

Since July I, I909, Snyder has been employed as agent and expert in the Bureau of Entomology, United States Department of Agriculture. He writes: "In October, 1909, investigated the dying of the short-lived Norway spruce in District of Columbia, New York, Long Island, Connecticut and Pennsylvania, to determine whether the death of the trees was due to insects anywhere else than in District of Columbia. From May, I9Io, to October, I9I0, investigated damage to the bases of chestnut and arborvitae telephone and telegraph poles by wood-boring insects in District of Columbia, Virginia, Maryland, New Jersey, New York and Pennsylvania. Much time was spent in traveling with railroad camp crews. From July to December, I9I I, investigated the cause of the dying of the pine in the southern states. Some time was spent at Forest Insect Field Station 7, Spartanburg, S. C., in educational work and public demonstrations as to the methods of controlling the southern pine beetle. From March I to date have been engaged in investigating the cause of the dying chestnut trees-particularly in the southern states, where the chestnut bark disease is not present. My chief individual work is working out the biology of termites (termes species) and determining methods of preventing damage by them to forest products. The life history of the common species will soon be published for the first time."

$\mathrm{He}$ is a member of All Souls Protestant Episcopal Church, New York City. In politics he is an Independent Republican. $\mathrm{He}$ is a member of the Entomological Society of Washington, the Biological Society of Washington, and is a Mason, a member of Lebanon Lodge 7, Kallipolis Grotto I5, M. O. V. P. E. R.

He has published: Damage to chestnut telephone and telegraph poles by wood-boring insects, Bull. 94, part I, Bur. Ent., U. S. Dept. Agric., Washington, D. C., Dec., I9ro; Damage to telephone and telegraph poles by wood-boring insects, Circ. I34, Bur. Ent., U. S. Dept. Agric., March 7, 
I9II; Insect damage to mine props and methods of preventing the injury, Circ. 156, Bur. Ent., U. S. Dept. Agric., July 13, 1912; Record of the finding of a true queen of termes flavipes kol., Proc. Ent. Soc., Washington, D. C., XIV, 2, pp. 107-08, pl. 3, June, 1912; Fauna telegraph and telephone poles, Biological Society, Washington, D. C., February, I9II; Record of the rearing of cupes concolor westw., Proc. Ent. Soc., Washington, XV, I; Notes on the biology of the common species of termites of eastern United States, Tech. Ser., U. S., Bur. Ent.

\section{Willard Springer, Jr.}

Business address, 1009 West Fourth Street, Wilmington, Del. Residence, 810 Washington Street, Wilmington, Del.

Willard Springer, Jr., was born April 8, 1886, in Wilmington, Del., the son of Willard Springer, a physician, and Etta (Frist) Springer. He has one brother, Harold L. Springer, M.D. University of Pennsylvania, and two sisters, Helen and S. Edith Springer.

He was prepared at the Wilmington High School and at the Wilmington Friends School, and in 1907 received the degree of C.E. from Lafayette, where he was a member of Delta Kappa Epsilon.

$\mathrm{He}$ is unmarried.

Upon graduation from the Yale Forest School Springer became forest assistant for the Pennsylvania Railroad and later was made assistant forester. Since the fall of 1912 he has been employed by Charles Beadenkopf \& Company, leather manufacturers.

\section{Chester H. Wilcox}

\section{Center Moriches, N. Y.}

Chester Harvey Wilcox was born September 17, 1883, in Brookhaven, N. Y., the son of Stephen B. Wilcox and Mary J. Wilcox. He has two sisters: Katherine G. Wilcox and Louise S. Wilcox, who is attending a school of elocution.

He was prepared at the Heffley School, Brooklyn, N. Y., and in 1907 received the degree of C.E. from Lehigh University, where he was a member of Alpha Tau Omega.

$\mathrm{He}$ is unmarried.

From July to October, I909, Wilcox was employed as forest assistant in the United States Forest Service with headquarters on Pend Oreille National Forest, Idaho. He was then appointed 
surveyor and forester for the Thompson Brothers Lumber Company, Houston, Texas, which position he held until June, I9II. In November, I9II, he became proprietor of Brookside Poultry Farm, where he is engaged in growing Pekin ducks.

$\mathrm{He}$ is a member of the Methodist Episcopal church and in politics is a Republican. He is a member of the Independent Order of Odd Fellows.

\section{Addison W. Williamson}

Business address, United States Forest Service, Washington, D. C. Residence, 1495 Newton Street, Washington, D. C.

Addison Wetherald Williamson was born March 7, I884, in Brooklyn, N. Y., the son of Rev. H. R. Williamson and Mary Matilda (Smith) Williamson. He has a brother, W. Rulon Williamson, B.A. Wesleyan 'og.

He was prepared at the Lincoln High School, Cleveland, Ohio, and in 1907 received the degree of $\mathrm{Ph} . \mathrm{B}$. from Wesleyan University, where he was a member of the National Commons Club.

He was married February 19, 1910, in Annapolis, Md., to Miss Mary Elizabeth Mylchreest of Middletown, Conn., daughter of William Mylchreest and Anne (Senogles) Mylchreest.

Upon graduation from the Yale Forest School Williamson was appointed forest assistant in the United States Forest Service, his present position. His headquarters are in Washington, D. C., where he is in charge of forest management in the East.

$\mathrm{He}$ is a member of the Methodist Episcopal church.

\section{Meyer H. Wolff}

Care United States Forest Service, Newport, Wash.

Meyer Henry Wolff was born December 27, 1887, in St. Petersburg, Russia, the son of Michael Wolff (deceased) and Esther (Kahn) Wolff. On his father's side both his grandparents were teachers, and his grandfather on his mother's side was a rabbi. He has one sister, Anna I. Wolf, B.A. New York State Normal College. Three cousins are Yale graduates: Meyer Kirjassoff, 'o6 S., Max D. Kirjassoff, '10, and Louis S. Kirjassoff, 'ro S.

He was prepared at the Waterbury High School, Waterbury, Conn., and at the DeWitt Clinton High School, New York City, and in 1908 graduated from the Sheffield Scientific School at Yale. 
He was married June 8, 1912, in Spokane, Wash., to Miss Merle Eugenia Jackson of Spokane, Wash., daughter of William H. Jackson and Inez E. Jackson.

Wolff is deputy forest supervisor in the United States Forest Service with headquarters at Newport, Wash. He entered the Service July I, I909, as a forest agent. On August 5, I9I I, he was appointed forest assistant, which position he held until September I, I9II, when he received his present appointment. He writes: "On graduation, left New Haven on Commencement Day and arrived via direct route at Anaconda, Mont., July 3, I909. Joined Northern Pacific coöperative estimate crews. Worked on Deerlodge, Missoula, Bitterroot and Lolo National forests. Had considerable independent work to do on Lolo Forest and later assisted in preparation of report on this forest. January, I9Io, was transferred to Kaniksu National Forest, with headquarters at Newport, Wash. Worked on timber sales and reconnaissance. Assumed charge of reconnaissance work in June. That summer fought fires and had an exceedingly strenuous time. Spent fall of I9IO and winter of I9IO-II on various administrative work; started reconnaissance in May, I9I I. Transferred later to timber sales and then appointed deputy supervisor. Had temporary charge of Kaniksu National Forest, February to June, I9I2."

Politically he is in sympathy with the Progressive party.

\section{Graduate holding Certificate but not Degree}

\section{Allen H. Hodgson}

Business address, United States Forest Service, Portland, Ore. Home address, I19 Fourth Street, Chico, Calif.

Allen Harrison Hodgson was born February 15, 1884, in Butte City, Calif., the son of William H. Hodgson and Mary A. (McDaniel) Hodgson. On his father's side he is of English and Dutch, and on his mother's of Scotch and Welsh ancestry.

His early life was spent on a California wheat ranch. He was prepared at Santa Rosa High School and in 1906 graduated from the California State Normal School.

He was married June 28, I9II, in Chico, Calif., to Miss Genevieve F. Pratt of Chico, daughter of Perry H. Pratt and Mattie Pratt. 
Hodgson entered the United States Forest Service July I, 1906, as forest guard. After leaving the Yale Forest School he was appointed forest assistant with headquarters on Shasta National Forest. He was then made forest supervisor of California National Forest and later assistant state forester of California. He again became forest assistant in the Service with headquarters on Klamath National Forest and on July I, I9I I, was made deputy forest supervisor of Siskiyou National Forest, Oregon. In January, I9I3, he was transferred to Ochoco National Forest.

$\mathrm{He}$ is a member of the Presbyterian church and in politics is a Progressive Republican.

\section{Non Graduates}

\section{Oliver E. Baker}

Business address, United States Department of Agriculture, Washington, D. C.

Home address, 39 West Perry Street, Tiffin, Ohio

Oliver Edwin Baker was born September 10, I883, in Tiffin, Ohio, the son of Edwin Baker (deceased), a merchant, born in Yarmouth, Mass., and Martha (Thomas) Baker, born in Pittsfield, Vt. Some of his ancestors were New England Puritans. He had two half-brothers, Frank and Walter Baker, and a half-sister, Nelly Baker, B.A. Heidelberg College (Ohio), all deceased.

In 1903 he received the degree of B.S. from Heidelberg College, Ohio, and in 1904 the degree of M.S., and in 1905 the degree of M.A. from Columbia University. While pursuing his graduate work he was a newspaper manager and teacher.

$\mathrm{He}$ is unmarried.

After leaving the Yale Forest School Baker did graduate work in the College of Agriculture, University of Wisconsin, where he worked on soil survey and the history of agriculture under the Carnegie Foundation. On July I, I912, he was appointed assistant agriculturist in the office of farm management of the United States Department of Agriculture, his present position. $\mathrm{He}$ writes: "After graduation from college in 1903, I was engaged in graduate study, newspaper work and teaching for a couple of 
years and had a nervous breakdown in 1905. As soon as I gained a little strength, I went to the Forest School, but the next year abandoned forestry for agricultural study. After four years of that, I am now in the office of farm management."

$\mathrm{He}$ is a member of the Methodist Episcopal church and in politics is a Progressive. $\mathrm{He}$ is a member of the Farm Management Association, the Eugenics Club of the University of Wisconsin and of two geographical societies.

He has published: Forest problem in an Ohio county, For. Rev.; and The Climate of Wisconsin and its relation to agriculture, Bull. 223, Wis. Agric. Exper. Sta.

\section{Hugh G. Calkins}

Business address, Box 556, Albuquerque, N. Mex.

Residence, 508 West Copper Avenue, Albuquerque, N. Mex.

United States Forest Service, Albuquerque, N. Mex.

Hugh Gilman Calkins was born August 21, 1884, in Rockport (now Lakewood), Ohio, the son of Carlos G. Calkins, a retired captain of the United States Navy, and Caroline (Cathcart) Calkins, daughter of Charles W. Cathcart of Ohio. On his father's side he is the descendant of early Puritan settlers in New England, who went to Ohio about 1840, and on his mother's side he is of English ancestry. He has a brother, Frank C. Calkins, B.S. University of California ' 99 and M.S. University of California.

He was prepared at the Berkeley High School, Berkeley, Calif., and at Swarthmore Preparatory School, and in 1906 received the degree of B.S. from the University of California.

$\mathrm{He}$ is unmarried.

Calkins is supervisor of Zuni National Forest with headquarters in Albuquerque, N. Mex., which position he has held since June I, I9II. During the year 1906-07 he was employed in the Service in California and after leaving the Yale Forest School in July, 1908, he was appointed forest assistant. In July, 1909, he became deputy forest supervisor and remained in this position until his present appointment. He writes: "Aside from occasional brief trips to the East or the Pacific Coast, my time has been spent wholly in work for the United States Forest Service in Arizona and New Mexico."

$\mathrm{He}$ is a member of the Society of American Foresters. 


\title{
William E. Dunham
}

Business address, Oliver Building, Pittsburgh, Pa. Residence, 32 I Coltart Square, Pittsburgh, $\mathrm{Pa}$.

\author{
Warren, $\mathrm{Pa}$.
}

William Edwin Dunham was born February 15, 1886, in Stoneboro, Mercer County, $\mathrm{Pa}$., the son of Omer Edwin Dunham and Florence (Burnett) Dunham. On his father's side he is of Irish and ScotchEnglish, and on his mother's of German and English ancestry. He has three brothers: Leon Burnett, Donald Albert and John Waldron Dunham.

He was prepared at the high school in Warren, Pa., and in I908 graduated from the Sheffield Scientific School at Yale, where he was a member of Theta Psi.

$\mathrm{He}$ is unmarried.

From July I, 1910, to February 15, I912, Dunham was forest assistant in the forestry department of the Pennsylvania Railroad. He was granted a leave of absence from November I5, I9II, to February I, I9I2, during which time he estimated timber and made timber examinations for the John L. Roper Lumber Company of Norfolk, Va. Since March 1, 1912, he has held the position of forester and Pittsburgh manager for Peters, Byrne \& Company, foresters and entomologists.

\section{H. Julian C. Humphrey}

Care of H. C. Humphrey, 42 Broadway, New York City

Henry Julian Correll Humphrey was born October I7, I887, in London, England, the son of Frank R. Humphrey and Edith (Learoyd) Humphrey.

He was prepared at Adelphi Academy, Brooklyn, N. Y., and received the degree of Ph.B. at Yale in 1908. He was a member of Theta Xi. $\mathrm{He}$ attended the Yale Forest School during 1907-08 and until the spring term in 1908-09.

In September, 1909, Humphrey went to work for Fisher, Cary \& Bryant, foresters, Boston, Mass. His present occupation is not known as he has sent no information for this record. 


\section{Richard L. Lovell}

Business address, Yale Station, New Haven, Conn.

Home address, 112 Crescent Avenue, Plainfield, N. J.

Lovell graduated from the Sheffield Scientific School, Yale University, in 1907. He is now studying in the Yale Graduate and Divinity schools and working in the city among boys.

\section{Axel E. T. Moberg}

Axel Erik Teodor Moberg was born in 1880 in Refteled, Sweden. He was prepared at Yönköpings hõgre allmönna lävoverk and attended Upsala University from 1900 to 1906. He studied at the Yale Forest School during a part of 1907-08. It is reported that he is in Germany, but it has not been possible to secure his present address.

\section{Ernest C. Wheeler}

Business address, 373 DeKalb Avenue, Brooklyn, N. Y.

Residence, 478 Greene Avenue, Brooklyn, N. Y.

6 Arch Street, Norwalk, Conn.

Ernest Cousins Wheeler was born September 30, 1885, in Norwalk, Conn., the son of Arthur Canfield Wheeler and Susan (Cousins) Wheeler. He has a brother, Harold Arthur Wheeler, Yale 'i2 S.

He was prepared at Norwalk University School and at the Connecticut Military Academy and in 1907 received the degree of B.A. from Yale University.

His engagement has been announced.

Since April, I9I2, Wheeler has been assistant sales and advertising manager of the J. \& T. Cousins Company of Brooklyn, N. Y. 


\section{CLASS OF 1910}

Graduates holding Degree of M.F.

\section{Walter G. Alpaugh}

Business address, Inter Ocean Life \& Casualty Company, Springfield, Ill.

Willimantic, Conn.

Walter George Alpaugh was born September 6, 1883, in Willimantic, Conn., the son of Charles Walter Alpaugh, agent and treasurer of the Holland Manufacturing Company and a director of the Willimantic Trust Company, and Estella (Honey) Alpaugh. $\mathrm{He}$ is of Dutch and English ancestry.

He received the degree of B.S. at Tufts College in Ig08, where he was a member of Theta Delta Chi.

He was married September II, I912, in Omena, Mich., to Miss Amy Allen Northcott of Springfield, Ill., daughter of William Allen Northcott.

After graduation Alpaugh was engaged in lumbering and forestry with the firm of Stetson \& Alpaugh. On October I, I9I2, he became a clerk for the Inter Ocean Life \& Casualty Company, insurance, of Springfield, Ill.

$\mathrm{He}$ is a Mason.

\section{William G. Baxter \\ Business address, Aspen, Colo. Galva, Iowa}

William George Baxter was born January 24, I885, in Galva, Iowa, the son of Robinson George Baxter, an Iowa State representative, and Esther (Scanlan) Baxter. Both parents are of Scotch-Irish ancestry. $\mathrm{He}$ has one sister and four brothers: Lillie Baxter, James R. Baxter, Urban S. Baxter, Robert B. Baxter, B.S.A. Iowa State College, and Luke J. Baxter, B.S.A. Iowa State College 'I3.

He was prepared at the Galva High School, Galva, Iowa, and received the degree of B.S.A. at Iowa State College in 1908.

He is unmarried.

Baxter has been engaged in reclamation work at Caldwell, Idaho, and since April I5, I9I I, has held the position of forest assistant in the Service, being located on the Sopris Forest with headquarters at Aspen, Colo.

$\mathrm{He}$ is a member of the Crystal City Club of Aspen, Colo. 


\section{George A. Bright, 2d}

Business address, Care United States Forest Service, Heppner, Ore. Home address, 1536 T Street, N. W., Washington, D. C.

Care United States Forest Service, Portland, Ore.

George Adams Bright, 2d, was born December 18, 1883, in Winchester, Mass., the son of George A. Bright, surgeon of the United States Navy from 1860 to 1898 , and Mary Chapman (Gale) Bright. He has a sister, Mary Bright.

He received the degree of B.S. at Dartmouth in 1908.

$\mathrm{He}$ is unmarried.

Bright has been engaged as a forest assistant in the United States Forest Service since graduation. $\mathrm{He}$ is located on the Umatilla Forest with headquarters at Heppner, Ore.

$\mathrm{He}$ is a member of the Unitarian church.

\section{Donald Bruce}

Business address, Forest Service, Missoula, Mont.

Home address, Easthampton, Mass.

Donald Bruce was born July 23, 1884 , in Newtonville, Mass, the son of Wayland Irving Bruce, Yale '82, who died in 1906, and Mary Emily (Skinner) Bruce. An uncle, Wallace Bruce, graduated from Yale College in '67.

$\mathrm{He}$ was prepared at Williston Academy, Easthampton, Mass., and graduated from Yale College in 1906 . While at college he was a member of the Freshman Union, of the Freshman Banjo and Mandolin clubs, of the Apollo Banjo and Mandolin clubs in his Sophomore year, and of the University Musical clubs in his Junior and Senior years; also of Kitcat Club, Chi Delta Theta, Psi Upsilon, Phi Beta Kappa and Sigma Xi. He was the recipient of the John Bennetto scholarship, of the Thomas Glasby Waterman scholarship, of the Barge Mathematical prize in his Freshman and Sophomore years and of a philosophical oration in his Junior year.

$\mathrm{He}$ is unmarried.

Bruce is forest assistant in the United States Forest Service with headquarters at Missoula, Mont. Before entering the Forest Service he spent two years teaching mathematics and physics at Williston Seminary, Easthampton, Mass. He entered the Service July I, I9IO, as forest assistant in the Helena National Forest. 
A year later he was transferred to the Coeur d'Alene National Forest, and in January, I9I3, received his present assignment. Early in I9I I he wrote:

"Since the career of mechanical engineer and of naval architect had ever seemed, throughout my college course, so equally enticing that a decision between them was exceedingly difficult, it was perhaps only natural that after graduation I should have clutched eagerly the birchen rod of the school teacher. For two years I was instructor of mathematics and physics at Williston Seminary, Easthampton, Mass. Having thus given myself ample time for choosing between the above-mentioned careers, I promptly entered the Yale Forest School, where I spent another two years in trying not to remember with what contempt I had, as an undergraduate, looked upon all members of the graduate departments of the University. Last March I passed through the ordeal of Civil Service examinations with sufficient success to be ordered westward, in July. Ever since I have been contentedly busy on the Helena National Forest, a very scattered area of some nine hundred thousand acres, lying anywhere from one to forty miles from the city of Helena, Mont. My work has been as diverse as is usual in this line of activity-including timber-estimating, land classification, surveying, mapping, and trying to remember which side of a horse it is more orthodox to attempt to ascend-but the major part of my time has been devoted to the Boulder Nursery, where I serve as chief nursemaid to some four million infant pines and firs."

He is a Republican-"probably progressive." $\mathrm{He}$ is a member of the Episcopal church.

He has written: A new method of constructing volume tables, For. Quart., June, I9I2.

\author{
Charles R. Clark \\ Business address, Dillon, Mont. \\ Home address, Carthage, III. \\ United States Forest Service, Washington, D. C.
}

Charles Rollin Clark was born December I3, I88r, in Carthage, IIl., the son of Lot Bozarth Clark, who was in the first class graduated at the University of Illinois, and Matilda Jane (Jackson) Clark. His father 
has been president of an independent telephone system in Illinois and superintendent of the University of Illinois Experiment Station at Carthage, Ill. His ancestors came from Ireland in 1670 and lived in Virginia until the Civil War. The Jackson family came from Scotland about 1720 and settled in Ohio, coming to Illinois about 1840 . He has five brothers and three sisters, five of whom are graduates of the University of Illinois, two are undergraduates and one is a prospective student: Matilda Lenna Clark, B.A. '03; John Ruskin Clark, B.A. 'o6; Richard Wagner Clark, B.A. 'o9; Faith Angeline Clark, B.A. '10; William Gladstone Clark, B.S. '12; Chester Arthur Clark, 'I4; Marshal Grant Clark, '16, and June Jackson Clark, 'r8.

He studied at the University of Illinois in 1903-04, and then entered the University of Wisconsin, Class of 1907. He received the degree of B.A. in 1909. During the summer of 1906 he worked for the United States Forest Service. While at the University of Wisconsin he served in various positions from private to major of first battalion in the cadet corps.

He was married June 16, 1910, in Ashland, Wis., to Miss Elma Mildred Pugh, daughter of Thomas Edward Pugh and Clara Pugh.

Clark has served as a forest assistant since graduation in I9I0. $\mathrm{He}$ is located at Dillon, Mont., the headquarters for the Beaverhead National Forest.

$\mathrm{He}$ is a Progressive in politics. He is a member of the Methodist Episcopal church and of Scabbard and Blade, an honorary military fraternity.

\section{Guy C. Cleveland}

Business address, The North Jersey Excelsior Company, Butler, N. J.

Home address, 333 Lincoln Avenue, Orange, N. J.

Guy Cory Cleveland was born June 25, 1882, in Albany, N. Y., the son of George Cleveland, formerly a member of Cleveland's Baking Powder Company of New York City, and Susan Lucy (Cory) Cleveland. He is of English ancestry. He has one sister, Gertrude (Cleveland) Storrs, Vassar '87, wife of Charles Bigelow Storrs, Yale '82, professor of law, University of Tokyo. A cousin, Cleveland Ferris, was Yale '03 M.

He was prepared at the Taft School and in 1908 graduated from Yale College, where he was captain of the 1008 Freshman Football Team and a member of the Freshman Baseball and College Baseball and Football teams. His fraternity was Delta Kappa Epsilon.

$\mathrm{He}$ is unmarried. 
After graduating from the Forest School, Cleveland became a forester for the New York and Pennsylvania Paper \& Pulp Company of Johnsonburg, $\mathrm{Pa}$. In I9II he became manager of the New York office of the R. E. Boyd Company, wholesale lumber dealers. On January 24, 1912, in partnership with Walter K. Wildes, M.F. 1910, he incorporated the North Jersey Excelsior Company at Butler, N. J. He is secretary and treasurer of this firm.

$\mathrm{He}$ is a member of the First Presbyterian Church of Orange, N. J. He is a Free Mason and a member of the Yale Club of New York City.

\section{Hamilton M. Coan}

Business address, Sumpter, Ore.

Home address, 27 West Ninety-seventh Street, New York City

Hamilton Morel Coan was born June 17, 1886, in New York City.

He was prepared at the Montclair High School, Montclair, N. J., and received the degree of B.A. at Princeton University in 1907.

$\mathrm{He}$ is unmarried.

Coan writes: "Since graduation from the Yale Forest School in June, I9I0, I have been continuously in the employ of the United States Forest Service. For a period of nearly two years I was assigned to work on the Chelan National Forest. This forest adjoins the main range of the Cascade Mountains (in the state of Washington) and has a very rugged topography of which I became fully aware before completing the extensive reconnaissance of the forest. The unique feature of this forest is the long and narrow lake included within its boundaries, which is at once a wonderful piece of natural scenery, and an effective aid to travel and fire protection. My work on this forest consisted almost wholly in estimating timber and in managing a timber sale.

"I am at present located upon the Whitman National Forest (Oregon), where for the past summer (I912) I have engaged in intensive reconnaissance. This work consists in the mapping of topography, the forest types timber cover, and an accurate examination and classification of the land to determine 
its value for agricultural purposes. In addition, the value of each section (the work thus far has been in surveyed country) is determined for grazing and an accurate ro per cent. estimate is made by an estimator who works along with the compassor map man. The accuracy of mapping is dependent to a very large extent on skilled use of the pocket compass and maintaining a consistent pace for all varieties of topography."

\section{George A. Cromie}

Business address, City Hall, New Haven, Conn. Residence, ${ }_{4}$ Compton Street, New Haven, Conn.

George Alexander Cromie was born December 27, 1883, in Scotstown, Quebec, Canada, the son of Henry James Cromie and Annie (Guy) Cromie. He has three sisters and two brothers: Beatrice Maud, Frances R., Flossie Olive, Robert James and Samuel Osborne Cromie.

He was married April 17, I9II, in New Haven, Conn., to Miss Anne Elizabeth Kavanagh, daughter of James Kavanagh and Alice Cullen Kavanagh. They have one son, Leonard James Cromie, born February 2, 1912.

In the fall of 19io Cromie became a forest assistant for the Canadian Government, but he returned to New Haven in I9II as superintendent of trees for the city.

$\mathrm{He}$ is a member of the Independent Order of Foresters and the New Haven Republican Club.

He has published (in collaboration with W. O. Filley, state forester) The planting and care of street and highway trees, and (in collaboration with Dr. W. E. Britton) The leopard moth.

\section{Robert E. Dickson}

\section{Business address, Boise, Idaho}

East Lansing, Mich.

Robert Emmett Dickson was born January 16, r888, in Akron, Ohio, the son of Chalmers McCall Dickson, a city health officer and secretary of the State Board of Health, also an expert examiner for United States Pensions, and Nancy Belle (Payne) Dickson. He is of Scotch and English ancestry. He has one brother, Matthew E. Dickson, who received the degree of B.S. at Michigan Agricultural College. 
He received the degree of B.S. at Michigan Agricultural College in 1909, having taken courses in agriculture and forestry.

He was married April 8, I912, in Saginaw, Mich., to Miss Eleanor Sybil FitzGibbon, daughter of P. E. FitzGibbon and Eleanore FitzGibbon.

Upon graduation from the Yale Forest School in I9Io Dickson served for a time as forest assistant, but he has given most of his time to teaching. He taught biology and agriculture at Highland Park Polytechnical Institute in Chicago, Ill., and on September I, I912, began work along similar lines at the Boise High School, Boise, Idaho. $\mathrm{He}$ is also director of the Boise District State Experiment Station, State Fair Grounds, Boise, Idaho.

He is a Progressive Republican. He is a member of the Roman Catholic church and of the Knights of Columbus.

\section{Richard C. Eggleston}

Business address, Forest Service, Saint Maries, Idaho

Home address, 236 Buckingham Place, Philadelphia, $\mathrm{Pa}$.

Richard Cunningham Eggleston was born February 2, 1885, in Brandy, Va., the son of Richard Irving Eggleston and Margaret Frances (Cornick) Eggleston. On his father's side he is of English, and on his mother's of English and Scotch descent. He has one brother, Thomas Cornick Eggleston, and two sisters, Emily Caldwell Eggleston and Martha Macon Eggleston.

He was prepared at the Central High School, Philadelphia, Pa., and studied one year at the University of Pennsylvania before coming to Yale. He graduated from the Sheffield Scientific School in 1909, where he was a member of Book and Bond and of the Southern Club.

$\mathrm{He}$ is unmarried.

Eggleston entered the United States Forest Service July I, I9IO, as forest assistant. He remained in this position until July, I9I I, when he resigned to become a forester for the Consolidation Coal Company of Jenkins, $\mathrm{Ky}$. In January, I9I2, he reëntered the Service, receiving the appointment of forest assistant with headquarters at St. Maries, Idaho.

$\mathrm{He}$ is a member of the Protestant Episcopal church. 
He has published: Forestry for mining companies, paper read before the West Virginia Coal Mining Institute, printed in Coal Age and one or two other mining magazines, December, I9I I.

\section{Robie M. Evans}

Business address, Beck Building, Portland, Ore. Home address, Fryeburg, Maine

Robie Mason Evans was born August 7, 1884, in Fryeburg, Maine, the son of Andrew Hill Evans and Huldah (Heath) Evans, who had three other children: Francis E. Evans, Alice M. Evans and Virginia W. Evans.

He received the degree of B.A. at Dartmouth College in 1906. The two years following he taught science in Kimball Union Academy, New Hampshire.

He is unmarried.

Since graduation Evans has served as forest assistant on the Oregon, Wallowa, Deschutes and Malheur National forests, all in the state of Oregon, District 6. He is now located at the district headquarters in Portland, being assigned to studies in silviculture.

$\mathrm{He}$ is Republican in politics.

\section{Harold Fay}

Residence, Winchester, Mass.

92 Professor's Row, Tufts College, Mass.

Harold Fay was born December 10, 1882, in Somerville, Mass., the son of Charles E. Fay, professor of romance languages at Tufts College and a charter member of the American Alpine Club, and Mary Williams (Lincoln) Fay. He is of English descent and a grandson of Cyrus Hyde Fay, a Universalist clergyman. He has two sisters: Ethel (Fay) Robinson, B.A. Tufts 'oo, and Margaret Fay.

He received the degree of B.A. at Tufts College in 1904. He was a member of Theta Delta Chi. He then taught in the Worthington (Mass.) High School one year, was with the Newton Fire Brick Company of Albany four months, served a year's apprenticeship in the advertising department of the Technical $W$ orld and six months as western advertising representative in Chicago, and business manager of Indoors and Out in Boston. The three years before entering the Forest School were spent in scaling and as a general laborer in the New Hampshire woods. 
He was married December 31, I9I2, in Meriden, Conn., to Miss Nina Edgerton Thompson, daughter of Edward S. Thompson and Minnie (Edgerton) Thompson.

From June to October, I910, Fay was consulting forester for the Batopilas Mining Company, Batopilas, Chihuahua, Mexico, and during the two months following acted as saw boss, scaler and skidder for the Madera Company, Ltd., Madera, Chihuahua, Mexico. He was an agent for the Connecticut Mutual Life Insurance Company in New Haven, January and February, I9I I, and from May to June assisted Professor Bryant at the Yale Forest School Camp at Trinity, Texas. From July, I9I I, to June, I9I2, he acted as timberman and surveyor for the John L. Roper Lumber Company, of Newbern, N. C. He has now purchased a farm in Winchester, Mass, and plans to combine scientific agriculture and consulting forestry work.

\section{Max H. Foerster}

Business address, Care Consolidation Coal Company, Jenkins, Letcher

County, Ky.

Home address, Sea Cliff, Long Island, N. Y.

Max Henry Foerster was born November 23, 1889, in New York City, the son of John Foerster.

He was prepared at the public schools at Sea Cliff, Long Island, until I90I, when he went abroad, remaining seven years. Before entering the Yale Forest School he attended Oberrealschule, Marburg, Hessen, Germany. He was a member of Book and Bond at Yale.

$\mathrm{He}$ is unmarried.

Foerster served as a forest assistant in the United States Forest Service eighteen months, one year at the Coconino Experiment Station and six months on the Coconino National Forest. In January, I912, he accepted a position as forester for the Consolidation Coal Company of Kentucky.

\section{William H. Gallaher}

Business address, Care Forest Service, San Francisco, Calif. Residence, Santa Barbara, Calif.

William Hallowell Gallaher was born September 14, 1887, in Santa Barbara, Calif., the son of F. M. Gallaher and A. R. (Hallowell) Galla- 
her. He has one brother, Hugh Gallaher, Harvard '15, and one sister, Mary Gallaher.

He was prepared at the Santa Barbara High School and attended the University of California for two years before entering Yale. He graduated from the Sheffield Scientific School at Yale in Igog.

$\mathrm{He}$ is unmarried.

Gallaher is forest assistant in the United States Forest Service, and has recently spent eighteen months traveling in Europe and India for the purpose of study. He entered the Service in July, I9Io, and is stationed in the Tahoe National Forest, California.

\author{
Harold P. Gilkey \\ Business address, Sumpter, Ore. \\ Richland, Mich.
}

Harold Parker Gilkey was born July 22, 1884, in Richland, Mich., the son of P. H. Gilkey and Adella (Parker) Gilkey. He is of Scotch and English ancestry. He has one sister, Mary Lovell Gilkey, who attended Michigan Seminary.

He received the degree of B.A. at Harvard in 1909.

$\mathrm{He}$ is unmarried.

Upon graduation from the School in I9Io Gilkey was assigned as a hydrographer in the United States Forest Service on work done in coopperation with the Geodetic Survey in the Puget Sound region. He held this position from July, I9Io, to July, I9II, and was then appointed forest assistant on Whitman National Forest with headquarters at Sumpter, Ore.

$\mathrm{He}$ is a Mason.

\title{
James L. Goodwin
}

Business address, Hartford National Bank Building, Hartford, Conn. Ior Farmington Avenue, Hartford, Conn.

James Lippincott Goodwin was born October 10, 188I, in New York City, the son of James Junius Goodwin and Josephine Sarah (Lippincott) Goodwin. His father has held the positions of trustee of Trinity College, Hartford, Conn., director of the Erie Railroad, director of the Connecticut Mutual Life Insurance Company of Hartford, director of the 
Holyoke Water Power Company of Holyoke, Mass., and director of the Collins Company of Collinsville, Conn. His father's ancestors lived in England and came to this country about 1630, settling in Connecticut. His mother's immediate ancestors were Quakers, living in Philadelphia, where she was born. Her more remote ancestors lived in England, coming to this country in 1640. He has two brothers: Walter Lippincott Goodwin, Yale '97, and Philip Lippincott Goodwin, Yale 'o7. He has two - cousins who are Yale graduates: Charles A. Goodwin, '98, and $\vec{F}$. Spencer Goodwin, 'o3. Another cousin, William B. Goodwin, is $e x-$ ' 89.

$\mathrm{He}$ was prepared at private schools in New York City and at Groton School, Groton, Mass. In 1905 he graduated from Yale College, where he was a member of the French Club.

He was married October I, 1912, in Hartford, Conn., to Miss Dorothy Wendell Davis, B.A. Smith 'o7, of Hartford, Conn., daughter of Frederick W. Davis, Yale '77, and Mary (Taintor) Davis, and sister of Carl W. Davis, Yale '02, and Roger W. Davis, Yale 'ir S.

Before entering the Forest School, Goodwin studied law for a year in the Yale Law School, but after traveling in Europe, Arizona and California, he became interested in forestry and decided to take a course in it. He entered the Harvard Forestry School, but after a year there left and entered the Yale Forest School. He writes: "Since leaving the Forest School I have been engaged in the private practice of engineering and forestry and carried on work in Vermont, Connecticut, New York and New Jersey. I had an office in New York with W. K. Wildes of my Class, but we were not in partnership. This private work I carried on until last May, when I came to Hartford and entered park work. I have recently been appointed field secretary to the Connecticut State Park Commission which was appointed in I9I I by the governor to make a report in I9I3 to the legislature on the sites available for state park purposes." $\mathrm{He}$ has recently formed the firm, the James L. Goodwin Associates, landscape architects.

$\mathrm{He}$ is an Independent in politics. $\mathrm{He}$ is a member of the Protestant Episcopal church and of the Yale Club of New York City, the Hartford University Club, the Hartford Golf Club, the Connecticut Forestry Association and the American Forestry Association.

He has written: A trip to the Lupai Indian Reservation near the Grand Canyon, Arizona, Hartford Courant, August, 1907. 


\section{Lester E. Hitchcock \\ Business address, Vernal, Utah \\ Forest Service Building, Ogden, Utah}

Lester Eugene Hitchcock was born September 22, 1884, in Chicago, III., the son of Horace Watson Hitchcock and Sarah Jane (Gibbons) Hitchcock. His father's family were originally Scotch-Irish people, who settled in the Carolinas, and his grandfather was killed during an engagement in the Civil War. He has one sister, Glennai Watson Hitchcock.

He was prepared at the Sioux Falls (S. Dak.) High School, worked one year, attended Yankton College two years, and was graduated at Coe College, Cedar Rapids, Iowa, in 1907 with the degree of B.S. Before entering the Yale Forest School he taught in a high school for one year.

$\mathrm{He}$ is unmarried.

Hitchcock is deputy supervisor on Ashley National Forest. He writes: "Since leaving Yale I have been engaged chiefly in reconnaissance work in various parts of District 4, with headquarters at Ogden, Utah, going first to the Kaibab Forest, located on the northern border of the Grand Canyon, the only scenery I have ever seen that I have never grown tired of, as there always seemed to be something new about it.

"Shortly after my summer there I spent a month in the pleasant little town of Ogden, whence I was sent as forest assistant to the Sawtooth Forest, where I received my only unpleasant experience in the Service, a four months' furlough. I got a chance to take some cattle to Seattle and so went there and spent a very rainy winter, getting some surveying and drafting to do, which kept me busy part of the time. For the last year I have done a variety of things, from counting sheep to surveying telephone lines, to say nothing of a one man reconnaissance, when $I$ was my own cook, horse wrangler, packer and did a full day's work every day besides."

$\mathrm{He}$ is a member of the Congregational church.

\section{Crosby A. Hoar \\ Business address, Meeker, Colo. \\ Home address, West Acton, Mass.}

Crosby Arthur Hoar was born September 9, 1886, in West Acton, Mass., the son of John Sherman Hoar and Minnie Rachel (Hart) Hoar. His 
mother is of Puritan descent and his father's family have lived in New England for several generations. He has two brothers, Carl S. Hoar, B.S. Dartmouth 'II, and Burton H. Hoar.

He was prepared in common schools, Lawrence Academy and received the degree of B.A. at Dartmouth in I908.

He is unmarried.

Since graduation Hoar has been an assistant in the United States Forest Service, being assigned to White River Forest, with headquarters at Meeker, Colo. He has recently been promoted to the position of forest examiner. During the spring terms of I9I I and I9I2 he was a field assistant at the Yale Forest School.

$\mathrm{He}$ is an Independent in politics.

\section{Stephen V. Klem}

Business address, Box 391, East Lansing, Mich.

Home address, 15 Lake Place, New Haven, Conn.

Stephen Vincent Klem was born November 6, 1885, in New Haven, Conn., the son of John J. Klem and Teresa S. (Newheim) Klem. He is the grandson on his father's side of George J. Klem and Elizabeth (Burns) Klem and on his mother's side of Adam Newheim and Mary (Healy) Newheim. He has one brother, John J. Klem, Jr., and two sisters: Elizabeth G. Klem and Teresa H. Klem.

He was prepared at the Boardman Manual Training (High) School and during the year 1905-06 was engaged as a salesman. In 1909 he graduated from the Sheffield Scientific School at Yale.

He was married November 20, 1912, in New Haven, Conn., to Miss Marguerite C. Dunlap of New Haven, Conn., daughter of Robert P. Dunlap and Eliza Savage Dunlap (deceased).

Klem writes: "I spent about four months in office of silviculture, District 2, at Denver, Colo,, about two months on winter reconnaissance on the Medicine Bow Forest in Wyoming and the remaining time until April, I912, I had headquarters at Custer, S. Dak. (Harney National Forest), where I held the position of forest assistant. In April, 1912, I obtained leave of absence until January, I9I3, returned to New Haven and did special investigation work on the taxation of forest land in Connecticut under the direction of the Connecticut State Forester." For a time he was station assistant in the Connecticut Agricultural Experiment Station at New Haven. During the past winter he 
conducted two lecture courses at the Michigan Agricultural College. He expects to continue his work there for another year.

$\mathrm{He}$ is a member of the Roman Catholic church.

\section{Julius A. Larsen}

Business address, Priest River Experiment Station, Priest River, Idaho United States Forest Service, Washington, D. C.

Julius Ansgar Larsen was born December 13, 1877, in Drammen, Norway, the son of Gustav W. Larsen, a sea captain, and Gorine (Hausen) Larsen (deceased). His ancestors on both sides of the family were seafaring men. He has one brother: Johannes Larsen, and three sisters: Sophie Christine Larsen, Othilie Gustava Larsen and Hermine Katherine Larsen.

He was prepared at East Maine Conference Seminary. Previous to this he had spent four years at sea and four years in different manufacturing concerns, among them the Winchester Repeating Arms Compay. In 1908 he graduated from Yale College, where he received an oration appointment and was a member of the Scandinavian Club.

He was married March 4, I9II, in Kalispell, Mont., to Miss Jenny Barghild Spieckermann of Christiania, Norway, daughter of Frederick and Hanna Spieckermann. They have one daughter, Margaret Elaine Larsen, born January 30, 1913.

Larsen is forest assistant in the United States Forest Service with headquarters at Priest River, Idaho. He was in charge of lumber reconnaissance, mapping, planting and studies on the Blackfoot National Forest, Kalispell, Mont., until April, 19r3, when he was transferred to the Priest River Experiment Station. He entered the Service July I, I9Io.

$\mathrm{He}$ is a member of the Congregational church.

He has written: Forests and Soils of Caldwell Parish, Louisiana, For. Quart., VIII, No. 4, I9II.

\section{Raymond E. Marsh}

Business address, Tres Piedras, N. Mex.

Home address, Westport, N.H.

Raymond Eugene Marsh was born January 27, I885, in Swanzey, N. H., the son of Walter Eugene Marsh and Jessie Henrietta (Tottingham) Marsh. His paternal grandfather, James Marsh, was descended from 
old Massachusetts settlers, and was the head of James Marsh \& Company, pail manufactuers of Swanzey, N. H., for fifty years. His wife was Candace Aldrich. His maternal ancestors were C. N. Tottingham, a carriage maker, descended from early settlers at Plymouth, Mass., and Rahie (Titus) Tottingham. He has two sisters, Alice Doris Marsh and Marion Elizabeth Marsh.

He was prepared at the Keene (N. H.) High School and received the degree of B.S. at Dartmouth in 1908.

$\mathrm{He}$ is unmarried.

Marsh entered the United States Forest Service in July, I9IO, and was first assigned to the Apache National Forest, Springerville, Ariz. He has since had charge of reconnaissance on the Carson Forest in New Mexico and in the fall of 1912 was appointed deputy forest supervisor of this forest, with headquarters at Tres Piedras.

$\mathrm{He}$ is a Republican. He is a member of the Methodist church.

\section{Frank B. Notestein}

Business address, Manitou, Colo.

\section{United States Forest Service, Denver, Colo.}

Frank Browning Notestein was born June 26; 1885, in Wooster, Ohio, the son of J. O. Notestein, head of the department of Latin, University of Wooster, Wooster, Ohio, and Margaret Bruce (Wallace) Notestein. His father's father was of German descent, the family having come to America in 1766, and his mother of English ancestry. His mother is the daughter of Benjamin Wallace and Margaret Bruce Wallace, who came from Scotland in the thirties. He has three sisters and a brother: Mary B., Lucy L., Margaret W., and Wallace Notestein, B.A. University of Wooster 'oo, M.A. Yale '03, Ph.D. '08.

Before entering the Forest School he camped for seven summers in the northern part of Michigan. He spent two summers as a forest guard on San Juan National Forest. He had made quite an extensive wood collection of the species of Ohio and Michigan. He received the degree of Ph.B. at the University of Wooster in 1908.

$\mathrm{He}$ is unmarried.

Notestein was appointed an assistant in the United States Forest Service in July, r9ro. He was in charge of the Fremont Experiment Station at Manitou in connection with the Pike National Forest, but is now forest examiner at the Wagon 
Wheel Gap Experiment Station, Colo. He has been in this position since July, I9I2.

$\mathrm{He}$ is a member of the Presbyterian church.

\section{Mauricio J. Oteyza}

Care Bureau of Forestry, Los Baños, Laguna, Philippine Islands

Mauricio Julian Oteyza was born October 18, I886, in Binondo, Manila, P. I., the son of Mauricio Oteyza y Reyes, a confectioner, son of Isidoro Oteyza y Reyes, and Ana Maria (San Juan) Oteyza y Reyes, daughter of Leocadio San Juan and Ynocensia (Torres) San Juan. He had two brothers Vincente Oteyza y Reyes, deceased, and Leonardo Oteyza y Reyes.

Until Ig02 he was a student for a B.A. degree at the Jesuit College, Manila. He then spent one year each in a business office, in the Philippine Normal School and teaching in the Government public school. From I905 to 1908 he attended the Kansas State Agricultural College, where he received the degree of B.S. in I9Io. He was a corporal in the cadet band and a recruit in the cadet corps at the latter school.

He was married August 12, 1912, in San Mateo, Rizal, P. I., to Miss Dolores Santamaria, daughter of Celerino Santamaria and Maria (Santos) Santamaria.

Oteyza was appointed assistant forester in the Bureau of Forestry, Philippine Islands, in February, 19ro, and was detailed to instruct at the School of Forestry, Philippine University, in June of the same year. A year later he was appointed instructor in silviculture and forest management.

$\mathrm{He}$ is a member of the Philippine Independent Church. $\mathrm{He}$ is a member of Alpha Beta Literary Society and a local musical society.

\section{Dana Parkinson}

Business address, United States Forest Service, Boise, Idaho Home address, 22 Howard Street, Waitham, Mass.

Dana Parkinson was born June 27, 1885, in Fergus Falls, Minn., the son of William Dwight Parkinson, superintendent of schools in Waltham, Mass., and Caro North (Bowman) Parkinson, a descendant of Elder Brewster of the Mayflower. He has three brothers: Royal Parkinson, B.A. Dartmouth '05, Taintor Parkinson, B.A. Dartmouth '09, and Herman Parkinson, Dartmouth 'I3. 
He received the degree of B.A. from Dartmouth in 1908.

$\mathrm{He}$ is unmarried.

Since July I, I9ro, Parkinson has been forest assistant in the United States Forest Service with headquarters in Boise National Forest, Idaho.

\title{
Stuart B. Show
}

\section{Sisson, Calif.}

Stuart Bevier Show was born April 9, 1886, in Waco, Neb., the son of Arley Barthlow Show, professor of European history at Leland Stanford, Jr., University since I892, and Busephalia (Wolph) Show. He is of Scotch-Irish and German descent on his father's side and of Scotch-Irish and French Huguenot on his mother's, his ancestors being pioneers in Wisconsin and Nebraska. He has three sisters and a brother: Esther Winifred (Show) Hopkins, Mary Wolph Show, Ruth Katherin Show and Joseph Henry Show.

He was prepared at the grammar and high schools of Palo Alto, Calif., and was graduated with the degree of B.A. at Leland Stanford, Jr., University in 1908.

He was married December 25, 1910, in Everett, Wash., to Miss Mabel Jeanet Griffin, daughter of John Luther Griffin and Clara O. Griffin.

Show has been an assistant in the United States Forest Service since July, I9ıo, being located at Sisson, Calif., headquarters for the Shasta National Forest.

$\mathrm{He}$ is a member of the Congregational church.

\section{William N. Sparhawk}

\author{
Business address, United States Forest Service, Emmett, Idaho \\ United States Forest Service, Ogden, Utah
}

William Norwood Sparhawk was born July 20, I888, in West Swanzey, N. H., the son of John W. Sparhawk, a member of the firm of C. M. Norwood \& Sons, boxmakers of Keene, N. H., and Nellie Louise (Norwood) Sparhawk. He is the grandson on his father's side of John $\mathrm{H}$. Sparhawk and Martha A. (Watkins) Sparhawk and a descendant of Nathaniel Sparhawk of Dedham, England, who settled in Cambridge, Mass., in 1638. On his mother's side he is the grandson of Charles Norwood and Lydia (Bolles) Norwood. He has one brother, Maurice C. Sparhawk, Dartmouth 'I4. 
He was prepared at the public schools in West Swanzey, N. H., and at the Keene High School, Keene, N. H. In Igo8 he graduated from Yale College, where he was a member of Phi Beta Kappa and recipient of a high oration Junior appointment. He was also a member of Alpha Sigma Phi, of the Hispanic Club, and in 1907 took the part of El Doctor in "El Doctor y El Enfermo."

He was married January 15, 1913, in Newark, N. J., to Miss Hazel Charlestine Ladd of Newark, N. J., daughter of Daniel A. Ladd and Emma (Staehle) Ladd.

Sparhawk is forest assistant in the United States Forest Service with headquarters at Emmett, Idaho. He entered the Service in July, 1910, and since then has been stationed at various times as forest assistant, in Salmon National Forest, Idaho, the Sevier National Forest, Utah, and the Payette National Forest, Idaho.

\section{Irving G. Stetson}

\section{Business address, I80 Exchange Street, Bangor, Maine}

Residence, 208 French Street, Bangor, Maine

Irving Gay Stetson was born November 23, 1885, in Bangor, Maine, the son of Isaiah Kidder Stetson, Yale '79 S., and Clara Cooper (Sawyer) Stetson. His father is president of the First National Bank, Bangor, an ex-treasurer of the University of Maine, has served in both sections of the State Legislature and as speaker of the House, and on the staffs of two governors. $\mathrm{He}$ is the son of George Stetson and of Adeline (Hamlin) Stetson, and a descendant in the eighth generation of Robert Cornet Stetson, of Plymouth Colony. His mother is the daughter of Frederick A. Sawyer, senator from South Carolina after the Civil War, and a direct descendant of Roger Conant of Massachusetts. $\mathrm{He}$ has one sister, Ruth Wolcott (Stetson) Beach.

He was prepared at Milton Academy (1898-99) and at Phillips Academy, Andover, Mass. (1899-03), and received the degree of B A. in 1907 at Harvard, where he was a member of the Hasty Pudding Club.

$\mathrm{He}$ is unmarried.

Upon graduation Stetson became a member of the firm of Stetson \& Alpaugh, lumbermen and foresters, and has been engaged in lumbering in spruce and pine and in general forestry work. The name of the firm has since been changed to I. G. Stetson \& Company. In I9I I he was appointed a director of the Penobscot Log Driving Company and a director of the First National Bank of Bangor, Maine. 
$\mathrm{He}$ is a Progressive Republican and a member of the Tarratine Club of Bangor.

He has published two articles in volume 8 of the Forestry Quarterly: Suggestions for studying growth, and Comparison of $\log$ rules.

\section{Albert O. Vorse}

Business address, Care Peters, Byrne \& Company, Ardmore, Pa. Home address, Lewisburg, $\mathrm{Pa}$.

Albert Ogden Vorse was born October 30, 1883, in Lewisburg, $\mathrm{Pa}$., the son of Walter Lyon Vorse and Christiana Bowman (Byers) Vorse.

Before entering the Yale Forest School he attended Bucknell University, where he received the degree of B.S. in 1905. He was then engaged in newspaper work eighteen months and in surveying for a year. He received the degree of M.S. at Bucknell University in IgII.

He was married June 17, I9I3, in Ardmore, Pa., to Miss Emma Yarnall, daughter of Mrs. Holton Hallowell Yarnall.

Since graduation Vorse has been employed in the Pennsylvania State Forest Service, assistant superintendent of woodlands for the Delaware \& Hudson Railroad, and since March, I9I2, forester for Peters, Byrne \& Company of Ardmore, Pa.

$\mathrm{He}$ is a Progressive, a Baptist and a member of the Merion Cricket Club of Haverford, Pa., the Cape May Yacht Club, Cape May, N. J., New York Society of the Sons of the American Revolution and the Yale Club of New York City.

\section{Robert S. Wallace}

\section{United States Forest Service, Harrison, Ark.}

Robert Sinclair Wallace was born November 2, 1885, in Wooster, Ohio, the son of James Wallace, professor of Greek in the University of Wooster, Wooster, Ohio, and president of Macalester College, St. Paul, Minn., and Janet (Davis) Wallace. $\mathrm{He}$ is of Scotch and English ancestry. He has two brothers and two sisters: Helen (Wallace) Davies, B.A. Macalester College, Benjamin Bruce Wallace, Ph.D., B.A. Macalester and post-graduate work at Madison and Oxford, W. R. DeWitt Wallace and Miriam Wallace.

He received the degree of B.A. at Macalester College in 1908.

He was married September 7, 1912, in Fairmont, Minn., to Miss Nina Johnson, daughter of Henry P. Johnson, M.D., and Ruth A. Johnson. 
Wallace has been engaged chiefly in reconnaissance work in District 3 since graduation. His first appointment was on the Pecos National Forest, New Mexico, followed by reconnaissance and experimental sample plot work on the Datil and Arkansas National forests. In the winter, I9II-12, he was on the Ozark Forest and again since the summer of 1912, being now occupied with timber sale work. His headquarters are at Harrison, Ark.

$\mathrm{He}$ is a Presbyterian.

\section{Edgar F. White}

Business address, United States Forest Service, Missoula, Mont. Home address, Danvers, Mass.

Edgar Fowler White was born October 28, 1885, in Danvers, Mass., the son of Charles H. White, president of the Danvers Savings Bank, and Etta Belle (Bucklin) White. He is of Scotch ancestry on his father's side. A brother, Cleon B. White, received the degree of B.A. at Dartmouth.

In 1908 he received the degree of B.A. at Dartmouth, where he was a member of Phi Gamma Delta.

He is unmarried.

White entered the Service in July, I910, as forest assistant and until April, 1912, was assigned to Custer National Forest. The following two months he was on Madison Forest and was then appointed to the planting department of District I at Missoula, where he is now acting chief of planting.

$\mathrm{He}$ is a member of the Congregational church.

\section{Walter K. Wildes}

Business address, Butler, N. J.

Residence, Little Falls, Passaic County, N.J.

Walter Keene Wildes was born June 9, I88I, in Skowhegan, Maine, the son of William Henry Wildes, a representative to legislature, on the board of selectmen, and a trustee of the Skowhegan Savings Bank, and Abby Judith (Keene) Wildes. His father's parents were Asa Waldo Wildes and Jane (Patten) Wildes and his mother's Josiah Keene and Adeline (Burrill) Keene. He has three brothers, Gordon L., Robert P., and William H. Wildes, Jr. 
He received the degree of B.A. in 1904 at Bowdoin, where he was a member of Delta Kappa Epsilon. Before entering the Yale Forest School he was engaged in the manufacture and selling of worsteds. In the summer of 1902 he was in the party in charge of W. C. Hodge, making valuation surveys on the property of the Great Northern Paper Company. During the summer of 1903 he was a member of the party in charge of R. L. Marston, studying poplars in the Dead River region of Maine.

He was married January 22, 1907, in London, England, to Miss Ruth Madeleine Beattie, daughter of William $H$. Beattie and Emma G. (Hollingshead) Beattie.

After graduation in I9Io Wildes became assistant state forester of Vermont. Since January, I9I2, he has been president of the North Jersey Excelsior Company, manufacturers of excelsior, at Butler, N. J.

$\mathrm{He}$ is Republican in politics. He is a member of the Episcopal church, the Yale Club of New York City, is a Free and Accepted Mason and a Royal Arch Mason.

He has published: Forest fires and the fire warden system in Vermont, The Vermonter, Dec., I9Io; State forests in Vermont, Am. For., May, I9II, and Forest working plans, Field and Stream, Aug. or Sept., I9II.

\title{
Graduates holding Certificate but not Degree
}

\author{
B. Frank Heintzleman \\ Business address, Sumpter, Ore. \\ Home address, Fayetteville, $P a$.
}

B. Frank Heintzleman was born December 3, I888, in Fayetteville, Pa., the son of Andrew Joshua Heintzleman and Rebecca Jane (Seitz) Heintzleman. $\mathrm{He}$ is of German descent.

He received the degree of Bachelor of Forestry at the Pennsylvania State Forest Academy in 1907 and was a forester in the Pennsylvania department of forestry for nine months prior to entering Yale.

$\mathrm{He}$ is unmarried.

Since July, I9ro, Heintzleman has been a forest assistant in the United States Forest Service. $\mathrm{He}$ is at present located on the Whitman National Forest with headquarters at Sumpter, Ore.

$\mathrm{He}$ is a Progressive Republican. 


\section{Sedman W. Wynne \\ Hot Springs, Tulare County, Calif.}

Sedman Walter Wynne was born May 24, 1883, in Butte, Mont., the son of Ellis Walter Wynne and Nellie Ware (Blood) Wynne. He has one sister, Edith Wynne.

Before entering the Yale Forest School he attended the University of California. He was a mining engineer from 1904 to 1908.

He was married January 20, 19I1, in San Jose, Calif., to Miss Margaret Ogier, daughter of John Ogier and Margaret Ogier.

Wynne was forest assistant in the United States Forest Service from July, I9I0, to July, I912, when he was appointed deputy forest supervisor of the Sequoia National Forest with headquarters at Hot Springs, Tulare County, Calif.

\section{Non Graduates}

\section{Edward S. Davey}

Business address, 95 River Street, Hoboken, N. J. Residence, 67 Hawthorne Avenue, Glen Ridge, N.J.

Edward Stiles Davey was born February 14, 1885, in Jersey City, N. J., the son of Edmund Howell Davey, chairman of the board of directors of the Hudson County Savings Bank, son of William O. Davey, and Emma Jane (Stiles) Davey, daughter of Edward Stiles. He has two brothers and a sister, Warren Davey, M.E. Stevens Institute of Technology, Leigh $\mathrm{H}$. Davey, Stevens Institute of Technology, and Lilian E. Davey. An uncle, William A. Stiles, was graduated at Yale in 1859, and a cousin, John A. Hartwell, in the Class of ' $89 \mathrm{~S}$.

He was prepared at Hotchkiss School, Lakeville, Conn., and was graduated with the degree of B.A. in 1908 at Yale College, where he was a member of Psi Upsilon.

$\mathrm{He}$, is unmarried.

Davey spent two years at the Union Theological Seminary, New York City, but did not complete the course. Since July I, I9I I, he has been engaged in social work, being acting secretary of the North American Civic League for Immigrants.

$\mathrm{He}$ is independent in his political views. $\mathrm{He}$ is a member of the Congregational church. 


\title{
Ernest G. Dudley
}

\author{
Business and home address, North Fork, Madera County, Calif. \\ Stanford University, Calif.
}

Ernest Griswold Dudley was born August 25, 1880, in Guilford, Conn., the son of James Austin Dudley (deceased), a farmer, who was state representative about 1882 and several times selectman of Guilford township and Emaline Wilcox (Griswold) Dudley. He is the grandson on his father's side of Samuel William Dudley and Lucy (Chittenden) Dudley of North Guilford, Conn., and on his mother's side of Henry B. Griswold. He has a brother, Harry Chittenden Dudley, Mn.E. Harvard '02; and three sisters: Lillian E. Dudley, Alice Griswold (Dudley) Soper of Orland, Maine, and Laura Elliott (Dudley) Shelley of Guilford, Conn., who attended Leland Stanford, Jr., University in 1907 and Smith College in $1908-09$.

He was prepared at Manzanite Hall, Palo Alto, Calif., and in 1908 received the degree of B.A. from Leland Stanford, Jr., University, where he was a member of Delta Upsilon. After the death of his father in I897 he managed the William Lusk farm in Guilford until I899, when he went to Stanford University and lived with his uncle, W. R. Dudley, professor of botany.

He was married July 7, 1909, in Palo Alto, Calif., to Miss Helen Annette Lewis of Palo Alto, daughter of James P. Lewis and Annie H. (Knight) Lewis.

Upon entering the United States Forest Service in July, I909, Dudley was appointed forest agent. Since I9Io he has been forest assistant with headquarters on Sierra National Forest, North Fork, Calif.

In politics he is a Progressive Republican.

\section{Ben Hershey}

Business address, 608 North Ainsworth Avenue, Tacoma, Wash.

Home address, Sterling, I1l. I026 Henry Building, Seattle, Wash.

Ben Hershey was born January 17, 1882, in Sterling, I1l., the son of Andrew Henry Hershey, a veteran of the I5th Illinois, I7th Army Corps, Army of Tennessee, and Harriet Elizabeth (Bowen) Hershey. He is of Swiss origin on his father's side and of Welsh on his mother's. He has two sisters, Marie Hershey, B.A. Wellesley '03, and Frances Genevieve Hershey, (Mrs. Jesse C. Moore), B.A. Wellesley '96. 
He was prepared at Lake Forest Academy, Lake Forest, IIl., and received the degree of B.A. in 1906 at Williams, where he was a member of Zeta Psi. He also attended Massachusetts Institute of Technology before entering Yale. He was registered at the Forest School during 1908-10.

$\mathrm{He}$ is unmarried.

Hershey is engaged in logging for the Angus McDougall Company of Tacoma, Wash.

He is a member of the Episcopal church.

\section{*Thomas Hooker}

Died 1909

Thomas Hooker was born July 20, I886, in Hartford, Conn., the son of Edward Beecher Hooker, M.D. Boston University '77, and Martha Clarke (Kilbourne) Hooker. His father is a descendant of Thomas Hooker on one side and of Lyman Beecher, Yale 1797, on the other, his parents being John Hooker, Yale '37, and Isabella (Beecher) Hooker. He has practiced medicine since 1878 in Hartford, Conn., and in 1907 was president of the American Institute of Homeopathy. He had two sisters Mary Hooker (Mrs. Henry E. Burton) and Alice Hooker (Mrs. John C. Day), and a brother, Joseph Kilbourne Hooker, Yale 'og.

He was prepared at the Hartford (Conn.) Public High School and received the degree of B.A. in 1908 at Yale, where he was a member of Delta Kappa Epsilon and the Yale News board.

He was unmarried.

Hooker had completed his first year at the Forest School when he was suddenly taken with appendicitis, of which he died at the Yale Infirmary, June 20, I909. He was an excellent student, a man of high ideals and of peculiar personal charm.

He was a member of Center Church, Hartford, and the Hartford Golf Club.

\section{James L. Leeper, Jr. \\ Business address, I700 Broadway, New York City \\ 304 Clinton Avenue, Kingston, N. Y.}

James Luther Leeper, Jr., was born September 2, I884, in Claysville, $\mathrm{Pa}$., the son of James Luther Leeper, D.D., pastor of the Dutch Reformed Protestant Church, Kingston, N. Y., a public lecturer and author, and Jane (McLaren) Leeper. He has a brother, Harper McLaren Leeper. 
He was prepared at the Robert Waller High School, Chicago, and the Lake Forest School, Lake Forest, Ill. He prepared for Cornell and entered the Sheffield Scientific School at Yale in Junior year, receiving the degree of $\mathrm{Ph} . \mathrm{B}$. in 1909.

$\mathrm{He}$ is unmarried.

Leeper took courses in the Yale Forest School in connection with his work in Sheff. After graduation from the latter school he spent two months in forestry work with the Great Northern Paper Company of Bangor, Maine. He then spent several months in Europe and upon his return went with the Prudential Insurance Company of Newark, remaining until November, I9II, when he became a bond salesman for Folsom \& Adams, New York City. On May I, I9I2, he organized J. L. Leeper \& Company, an automobile brokerage firm of which he is president.

$\mathrm{He}$ is a member of the Dutch Reformed Protestant Church of Kingston, N. Y.

\section{Samuel B. Locke \\ Business address, Hailey, Idaho \\ Forest Service Building, Ogden, Utah}

Samuel Barron Locke was born March 10, I885, in Paris, Maine, the son of Samuel Barron Locke, who held several town offices and was a member of the state legislature, and Elva Estelle (Libby) Locke. $\mathrm{He}$ is of English ancestry. He has two sisters: Linda (Locke) Marshall and Mary (Locke) Gerrish.

He was prepared at the Paris and Woodford (Maine) high schools and in 1908 received the degree of B.S. at the University of Maine, where he was a member of Sigma Chi and a corporal in the cadet corps.

He was married January I, I9I2, in South Paris, Maine, to Miss Olive Chase Swett, daughter of Benjamin Swett and Imogene Andrews Swett.

Locke is deputy forest supervisor of Sawtooth National Forest with headquarters at Hailey, Idaho. He writes: "The summer and fall of rgIo I spent on reconnaissance work in the Salmon National Forest, Idaho. The winter of I9IO-I I in Ogden, Utah, on reconnaissance reports and maps. The spring, summer and fall of IgI I in general work on forest nursery, forest planting, surveying, etc., on the Sawtooth National Forest, Idaho. The 
winter of I9II-I2 I was in charge of a correspondence course of study for rangers in Ogden. The spring of 1912 was engaged on forest nursery work, timber sales, etc., and the summer and fall, mapping, etc., on the Sawtooth National Forest."

$\mathrm{He}$ is a Progressive Republican.

\section{Glenn W. Traer, Jr.}

Business address, 8 South Dearborn Street, Chicago, III. Residence, 4363 Oakenwald Avenue, Chicago, III.

Glenn Wood Traer, Jr., was born April 9, I889, in Chicago, Ill., the son of Glenn Wood Traer, chairman of the Illinois mining commission, and Ida (Solberg) Traer. $\mathrm{He}$ is of Scotch-English and Scandinavian ancestry. He has two brothers and two sisters: Charles S. Traer, Yale 'Io S., Josephine Traer, Morton Traer and Elsa Traer.

He was prepared at the Harvard School, Chicago, Ill., and received the degree of Ph.B. at Yale in 1909. He was a member of Chi Phi. $\mathrm{He}$ is unmarried.

Traer took the Forestry Course in Sheff and in Senior year completed a portion of the Junior Forest School work. In the fall of 1909 he entered a law office and also studied at the Kent College of Law in Chicago. He entered the coal mining business at Danville, Ill., in March, 1910, and held various positions, such as engineer, clerk, salesman and assistant superintendent, until April, 1912, when a strike amongst the miners of Illinois led him to give up that occuption temporarily. $\mathrm{He}$ is now assistant to the sales manager of A. B. Leach \& Company, dealers in bonds and securities.

\section{Alvin G. Whitney}

St. Paul Island, Behring Sea, Alaska

Alvin Goodnow Whitney was born March 2, I883, in Hamilton, Ont., Canada. Before entering the Yale Forest School he studied at Dartmouth College. He entered the School in 1908-09 and took the Senior work in 1909-10 until the spring term and returned in I9II-I2 to take certain courses.

He was married July 28, 1912, in Washington, D. C., to Miss Gibson.

Whitney is located at St. Paul Island, Behring Sea, Alaska. He has not furnished any information for this record. 


\title{
CLASS OF I9II
}

Graduates holding Degree of M.F.

\author{
Waldo D. Barlow \\ Business address, Helena, Mont. \\ Home address, South Manchester, Conn.
}

Waldo Darius Barlow was born April 10, 1885, in Sturbridge, Mass., the son of Darius R. Barlow, a farmer, and Lucy F. (Gilbert) Barlow. $\mathrm{He}$ is of English ancestry. He has a brother, Harry E. Barlow, B.A. Amherst 'o7, and a sister, Mrs. Henry L. Sweet.

$\mathrm{He}$ was an instructor in agriculture and horticulture in the Kamehameha schools, Honolulu, H. T., from 1905 to 1907 , and in 1909 received the degree of B.S. from the Massachusetts Agricultural College, where he was a member of Phi Sigma Kappa and had two years of military training.

He was married December 18, 1912, in Helena, Mont., to Miss Clorinde von Heinrichshofen of Helena, daughter of Mrs. H. von Heinrichshofen.

Barlo writes: "Was appointed forest assistant in the United States Forest Service July I, I9I I, and assigned to the Helena Forest. Was given charge of the Boulder Nursery at Boulder, Mont. On December 12, I9II, was assigned to the district office of District I of the Forest Service to assist in silviculture. Returned to Helena Forest in the spring of I9I2 to again take charge of the Boulder Nursery, where I am at present."

$\mathrm{He}$ is a member of the Unitarian church and in politics is a Progressive Republican.

\section{Oliver F. Bishop}

Business address, Bureau of Forestry, Los Baños, Laguna, Philippine Islands

Home address, 174 Grand Avenue, New Haven, Conn.

Oliver Frederick Bishop was born October 3, I888, in New Haven, Conn., son of Frederick Foote Bishop, superintendent and treasurer of the New Haven Ice Company (died January 21, 1895), and Alice M. (Bradley) Bishop. $\mathrm{He}$ is of English ancestry, the grandson on his father's side of Elias Bradley Bishop and Grace C. (Atwater) Bishop, and on his mother's side of Oliver S. Bradley and Annie Tyler (Deane) 
Bradley. Two of his great uncles were graduated at Yale: Lyman Hotchkiss Atwater, '31, D.D. Princeton '51, LL.D. '73, and Wyllys Atwater, '43, and several cousins, among them Hon. William Henry Bishop, '67, former United States consul and author, and Lyman Hotchkiss Bagg, '69, author of "Four Years' at Yale." He has one sister: Lottie G. Bishop, B.A. Mount Holyoke '06.

He was prepared at the Boardman Manual Training High School, New Haven, and received the degree of Ph.B. from the Sheffield Scientific School at Yale in 1909. He received general two-year honors in Senior year, divided the Belknap Prize in biological studies, was elected to Sigma Xi, and a member of Alpha Sigma Phi.

$\mathrm{He}$ is unmarried.

During Junior year in the Yale Forest School Bishop conducted a course in forestry, consisting of lectures and field work, at Rhode Island State Agricultural College. He entered the Government Service in July, I9Io, receiving an appointment as forest assistant on the Apaché National Forest. In September he obtained a furlough and returned to the School to complete his course. In July, I9II, he resumed his work with an assignment to the Carson National Forest, New Mexico, and in the winter of that year was transferred to the Ozark and later to the Arkansas, both in Arkansas. He spent three months at home on sick leave in the spring of 1912 , returning in June to the Carson. The winter of 1912-13 was spent at Albuquerque on inside work. In February he accepted an appointment under the Philippine Bureau of Forestry and reached Manila on April Io. His title is that of forester and he has been engaged in cataloguing several thousand volumes and has taken a number of trips with groups of students from the University.

He is a member of the Episcopal church.

\section{Elwood P. Bushnell}

Business address, United States Forest Service, Washington, D. C. Home address, Bronson, Mich.

Elwood Perry Bushnell was born January 27, 1885, in Bronson, Mich., the son of William B. Bushnell, who has held the position of representative in the Michigan legislature and various township and county offices, and Sarah Maria (Taggart) Bushnell. He has three brothers: Leland D. Bushnell, B.S. Michigan Agricultural College, Clyde E. Bushriell and Clesson T. Bushnell. 
Before entering the Forest School he had spent four winters in a lumber camp and three summers surveying. In I9Io he received the degree of B.S. from the Michigan Agricultural College, where he was a member of Phi Delta and of the varsity track team and filled all positions up to and including that of major in the cadet school.

$\mathrm{He}$ is unmarried.

Since graduation from the Yale Forest School Bushnell has been an assistant in the United States Forest Service with headquarters in Washington, D. C.

$\mathrm{He}$ is a member of the Baptist church and in politics is a Progressive. At Yale he was elected to Acacia Fraternity and he is also a member of Mystic Lodge, 4I, Free and Accepted Masons, and of Siroc Chapter, 46, Royal Arch Masons, both of Bronson, Mich.

\section{Norman C. Case}

Business address, Silver City, N. Mex.

Home address, Highland, Kans.

Albuquerque, N. Mex.

Norman Curtis Case was born April 1, 1885, in Highland, Kans., the son of Norman Case, who has held the positions of trustee of Highland College, mayor and postmaster of Highland, and Harriet Allice (Moll) Case. On his father's side he is of English and Scotch ancestry, being the grandson of Edward Case and Ann Walk (Curtis) Case; and on his mother's side of German and Swiss descent, the grandson of Eli Moll and Elizabeth (Schock) Moll. He has a brother, William Moll Case, B.A. Highland College '02, Yale $e x-{ }^{\prime} 04$, and a graduate of Auburn Theological Seminary in I908; and a sister, Helen Lillian Case, B.A. Highland College 'I0, who also did graduate work at Northwestern University.

He received the degree of B.S. from Highland College in 1908 and afterward did graduate work at Kansas University.

$\mathrm{He}$ is unmarried.

Case entered the United States Forest Service on July I, I909, as forest agent and from that time until October I, I909, worked on reconnaissance on Helena and Gallatin National forests, Montana. From October I to December 3I, I909, he was engaged in reconnaissance on Sioux National Forest, North and South Dakotas; from January I to April I, I9IO, in timber sales on Bitterroot National Forest, Montana; and from July I to September, I9I0, in surveying on Flathead National Forest, Montana. 
Upon graduation from the Yale Forest School he was appointed forest assistant on timber reconnaissance and from July I to November, 19II, was stationed on Carson National Forest, New Mexico; from November to December 3I, I9I I, on Ozark Forest, Arkansas; from January I to May I, I9I2, on Arkansas Forest, Arkansas; and since May I on Gila Forest, New Mexico, where he is at present. On May I, I9I3, he was advanced to the position of forest examiner.

$\mathrm{He}$ is a member of the Presbyterian church and in politics is a Progressive Republican.

\section{Bernard A. Chandler}

Business address, Vermont Forest Service, Burlington, $V t$.

Home address, New Gloucester, Maine

Bernard Albert Chandler was born December 20, 1884, in New Gloucester, Maine, the son of Andrew Campbell Chandler, a farmer and engaged in the mill and lumber business, being a member of the firm of Chandler Brothers, and Cora Evelyn (Bean) Chandler. $\mathrm{He}$ is the grandson on his father's side of Andrew Campbell Chandler and Catherine C. (Cunningham) Campbell, and on his mother's of Albert F. Bean and Ann J. (Rice) Bean. He has a brother, Robert Flint Chandler, B.S. University of Maine '03, and a sister, Sara Archer Chandler.

He was prepared at the Edward Little High School, Auburn, Maine, and in 1909 received the degree of B.S. from the University of Maine, where he was a member of Phi Kappa Sigma.

$\mathrm{He}$ is unmarried.

Since graduating from the Yale Forest School Chandler has held the position of assistant state forester of Vermont with headquarters at Burlington.

$\mathrm{He}$ is a member of the Congregational church and in politics is a Progressive Republican. He is a member of the Grange.

\section{Neal T. Childs}

Business address, Care United States Forest Service, Bakersfield, Calif. Home address, Bretton Hall, Broadway and Eighty-sixth Street, New York City

Neal 'Townley Childs was born February 22, 1884, in Nicholson, $\mathrm{Pa}$., the son of George W. Childs, vice president and manufacturing manager 
of the Central Leather Company of New York City, and Florence (Moore) Childs, daughter of G. V. Moore. His paternal grandparents were Nial Townley Childs and Marilla (Weston) Childs.

$\mathrm{He}$ was prepared at the Ridgway public schools and at Phillips Academy, Andover, Mass., and in I909 graduated from Yale College. He entered Yale with 1908 S., but joined 1909 at the beginning of Sophomore year. He was a member of the $1908 \mathrm{~S}$. Class Crew, of the Freshman Union and the Yale Union, and received a third TenEyck prize in the Junior Exhibition. His society was Psi Upsilon. In 1903 he spent six weeks with the Forest Service working on the sand dune problem in Michigan. He traveled for six months in Europe in I903. During the summer of 1907 he traveled by canoe through the Canadian National Park in northern Ontario. He spent the summer of 1908 in the Adirondack forests.

He was married June I0, I9I2, in San Francisco, Calif., to Miss Hazel Irene Moise of San Francisco, Calif., daughter of Mr. and Mrs. Philip H. Moise.

Childs is forest assistant in the United States Forest Service with headquarters at Bakersfield, Calif. He entered the Service July I, I9II. He writes: "Traveled through Yellowstone National Park in the summer of I9Io. Spent two months in the Coast and Cascade forests of Washington and Oregon making studies in western hemlock in I9IO. Visited the Grand Canyon of Arizona in I9I I and spent two months traveling by horseback on main Sierra divide of Kern and Sequoia National forests collecting herbarium specimens and making a silvical description of the former forest."

$\mathrm{He}$ is a Progressive in politics. He is a member of the Methodist Episcopal church. He belongs to the League of American Sportsmen and the American Forestry Association.

\section{Walter J. Damtoft}

Business address, United States Forest Service, Washington, D. C. Home address, 98 Beechwood Avenue, Bridgeport, Conn.

Walter Julius Damtoft was born November II, I890, in Southport, Conn., the son of Kund Julius Damtoft and Dagmar Elizabeth (Jacobi) Damtoft. He is of Danish descent. He has one brother, Frank V. Damtoft.

He was prepared at the Bridgeport High School and in Iglo graduated from the Sheffield Scientific School at Yale.

$\mathrm{He}$ is unmarried. 
Damtoft has been a field examiner in the United States Forest Service with headquarters at Washington, D. C., since May, 1912. $\mathrm{He}$ entered the Service in I9II and during that year was employed in the Routt and Arapaho National forests. In 1912 he did Weeks bill work in the southern Appalachians.

$\mathrm{He}$ is a member of the South Congregational Church of Bridgeport, Conn.

\author{
Howard deForest \\ Business address, Weaverville, Calif. \\ Care of J. D. deForest, 25 Broad Street, Nezw York City.
}

Howard deForest was born November 2, 1872, in New York City, the son of Albert Henry deForest and Jane Amelia (Douglas) deForest. He has a brother, John Douglas deForest, and a sister, Edith Beatrice deForest.

He was prepared at H. W. King's School, Stamford, Conn., and in I895 received the degree of B.S. from Princeton University. During a part of the year 1908-09 he attended the Forest School at the University of Michigan.

$\mathrm{He}$ is unmarried.

Since graduating from the Yale Forest School deForest has held the position of forest assistant in the United States Forest Service with headquarters at Trinity National Forest, Weaverville, Calif. During the latter part of the academic year of 1912I3 he was acting assistant professor of forestry at the University of Missouri.

In politics he is a Progressive. He is a member of the Holland Society of New York and of the Sons of the American Revolution of New York State.

\title{
Theodore W. Dwight
}

Business address, Forestry Branch, Ottawa, Canada

Residence, Y. M. C. A., Ottawa, Canada

Theodore Woolsey Dwight was born June 30, 1889 , in Geneva, I1l., the son of William Cecil Dwight and Ruth A. (Bristol) Dwight. He is the grandson on his father's side of ex-President Timothy Dwight, D.D., LL.D., of New Haven, and the great-grandson of the older President Dwight of Yale, and on his mother's side the grandson of Almon Bristol 
of Picton, Ont., a descendent of United Empire Loyalist stock. He has a brother, Herbert B. Dwight, B.S. McGill University, Montreal, and a sister, Edith C. Dwight, B.A. University of Toronto.

He was prepared in the public schools of Picton, Ontario, and at the Toronto High School and in 1910 received the degree of B.S.F. from the University of Toronto.

He is unmarried.

Since graduating from the Yale Forest School Dwight has been employed as forester in the Forestry Branch of the Department of the Interior, Canada, where he is connected with the main office.

$\mathrm{He}$ is a member of the Congregational church and in politics his sympathies are with the Republicans in the United States and the Liberals in Canada.

\section{John H. Fahrenbach}

Business address, United States Forest Service, Washington, D. C. Home address, Bernville, $\mathrm{Pa}$.

John Henry Fahrenbach was born June 19, 1888, in Bernville, $\mathrm{Pa}$., the son of George D. Fahrenbach, sheriff of Berks County, and Mary E. (Ziebach) Fahrenbach. He is of German ancestry. His father served three years in the Civil War in the 55th and I5Ist Pennsylvania Volunteer Infantry, was in seventeen engagements and wounded four times. $\mathrm{He}$ has two sisters: Sallie and Mary R. Fahrenbach, both graduates of the Keystone State Normal School; and two brothers: Frank Fahrenbach, a graduate of Stoners Business College, and George W. Fahrenbach, M.D. Baltimore Medical College.

In $x 909$ he received the degree of B.A. from Franklin and Marshall College, where he was a member of the Harbaugh Club.

$\mathrm{He}$ was married June 22, I9II, in Wernersville, $\mathrm{Pa}$., to Miss Bertha Mae Kauffman of Wernersville, daughter of Morris Kauffman and Annie (Roether) Kauffman.

Since June 26, I9II, Fahrenbach has been forest assistant in the United States Forest Service with headquarters at Washington, D. C.

$\mathrm{He}$ is a member of the Reformed church. At Yale he was elected to Sigma $\mathrm{Xi}$ and he is also a member of the Independent Order of Odd Fellows and of Williamson Lodge, 307, Free and Accepted Masons. 


\section{Arthur F. Fischer \\ Business address, Bureau of Forestry, Manila, $P . I$. Home address, 5918 Ohio Street, Chicago, III.}

Arthur Frederick Fischer was born February 6, I888, in Chicago, III., the son of Joseph Fischer, engaged in the meat packing business in Chicago, and Mary (Ehredt) Fischer. He is of German ancestry. He has a sister, Mary L. Zuttermeister, who graduated from a convent, and three brothers: H. H. Fischer, George Fischer and Oscar Fischer, M.E. Columbia School of Mines.

He was prepared at Crane Technical School, Chicago, and afterward was employed by Rand McNally \& Company as map draftsman. He worked for the Tennessee Coal Iron \& Railroad Company of Birmingham on traces and details and later surveyed coal lands in Tennessee. In 1909 he received the degree of C.E. from Ohio Northern University, where he served as private, corporal, sergeant, lieutenant and captain in " $\mathrm{B}$ " Battery.

He was married June 21, I9II, in East Chicago, Ind., to Miss Helen Wyly Beall Campbell of Ada, Ohio, daughter of Lawrence William Campbell and Ella Meader Campbell.

Since graduating from the Yale Forest School Fischer has been employed as forester in the Bureau of Forestry, Philippine Islands. He writes: "Have traveled in and about the Philippines on special detail under the director of forestry, not confined to district, working mostly along the line of opening up timber tracts for large concessions, making rough working plans for them and inspecting the large lumber companies in the Islands. When not thus occupied have been detailed to the Forest School of the University of the Philippines as instructor in forest engineering."

$\mathrm{He}$ is a member of the Presbyterian church.

\section{Charles Goodwin}

Business address, Woodlands Department, Delaware \& Hudson Railroad, Plattsburg, N. Y.

Home address, 1070 Bushwick Avenue, Brooklyn, N. Y.

Charles Goodwin was born November 23, 1887, in Brooklyn, N. Y., the son of George Bennett Goodwin, a director of the Merchants' Bank and president of the George B. Goodwin \& Brother Coal Company, and Eleanor Eliza (Goodman) Goodwin. On his father's side he is the 
grandson of Charles Goodwin, editor of the Brooklyn Times, and Hannah Goodwin, both English, and on his mother's side of D. Goodman and Emma Goodman of Virginia. He has two sisters: Florence W. Goodwin and Hannah Goodwin.

He was prepared at the Polytechnic Preparatory and Pratt High School of Brooklyn, N. Y., and in I9Io graduated from the Sheffield Scientific School at Yale, where he was a member of Berzelius, Delta Theta, the Freshman and Varsity Basketball teams and the Kopper Kettle Klub.

His engagement has been announced.

Goodwin is chief of survey for the Delaware \& Hudson Railroad Company. He has held this position since graduation from the Forest School in June, I9II.

$\mathrm{He}$ is a Republican and is a member of the Episcopal church. He belongs to the Wolf Pond Athletic Club.

\section{Alfred B. Hastings}

Business address, Orofino, Idaho

Home address, Hanover, N. H.

Alfred Bryant Hastings was born February 19, 1882, in Claremont, N. H., the son of Lemuel Spencer Hastings, assistant professor of English at Dartmouth College and for many years principal of high schools, and Laura Maria (Cobb) Hastings. He is the grandson on his father's side of Lemuel Hastings, a farmer and cattleman of St. Johnsbury, Vt., and on his mother's of Samuel B. Cobb, a merchant of Hanover, N. H. He has a brother, Harold R. Hastings, B.A. Dartmouth 'oo, M.A. Harvard ' $\alpha 2$ and Ph.D. University of Wisconsin 'ro, and a sister, Myra Hastings, B.A. Smith '05.

He received the degree of B.A. in 1904 from Dartmouth College, where he was a member of Delta Tau Delta. He taught mathematics from 1904 to 1906 at Holderness School, from 1906 to 1907 at Milton Academy and from 1907 to 1909 at St. Paul's School.

He is unmarried.

Since graduating from the Yale Forest School Hastings has been employed as forest assistant in the United States Forest Service with headquarters in Clearwater National Forest. He writes: "From July I, I9II, to June, I9I2, I was engaged in general office work on the Clearwater National Forest at Orofino, Idaho. This work was varied during the spring by my joining the telephone construction crew of the forest and by the handling of a very small planting operation. From July Io as far into 
the fall as the weather permitted was engaged in type mapping on a very extensive basis in the watershed of the North Fork of the Clearwater River with one assistant or guide, a packer and five horses."

$\mathrm{He}$ is a member of the Episcopal church. Concerning politics he writes that he believes in tariff for revenue only and in centralized government. He is a member of the American Forestry Association.

\section{James O. Hazard}

Business address, Forest Commission, State House, Trenton, N. J. Residence, 59 Delaware View Avenue, Trenton, N. J. Home address, Westerly, R. I.

James Ovington Hazard was born October 4, 1884, in Charlestown, R. I., the son of Nat Hazard and Harriet Saphia (Warner) Hazard. He is of English ancestry. He has a brother, Robert Hazard, and three sisters: Amey Almira, Natalie Sabra and Beulah Iris Hazard.

He spent his early life on a farm and attended the public schools, and in 1908 received the degree of $\mathrm{Ph} . \mathrm{B}$. from Brown University, where he was a member of Kappa Sigma.

He was married June II, I9I3, in Toledo, Ohio, to Miss Emma Elizabeth Backus, daughter of Samuel Reed Backus and Elizabeth Hoagland Backus.

From July to September, I9II, Hazard was instructor in the Yale Forest School. Since September 27, I9II, he has been assistant state forester for the state of New Jersey.

$\mathrm{He}$ is a member of the First Baptist Church.

\section{Jesse W. Hough}

Claremont, Calif.

Jesse Winegar Hough was born October 24, 1885, in Santa Barbara, Calif., the son of Theodore Holmes Hough, principal and teacher in the public schools, Santa Barbara, and Helen Eliza (Clarke) Hough, daughter of a New York State merchant. His father is the son of J. W. Hough, a Congregational minister, and brother of W. S. Hough, a professor at George Washington University.

He was prepared at Pomona Preparatory School and in 1908 received the degree of B.S. from Pomona College, following which he took a year of work in natural science at Leland Stanford, Jr., University.

$\mathrm{He}$ is unmarried. 
From July, I91 I, to April, I912, Hough was forest assistant in the United States Forest Service with headquarters on Angeles National Forest, California. Since then he has been engaged in orange growing in Claremont, Calif., where he owns an orchard.

$\mathrm{He}$ is a member of the Congregational church and in politics is a Progressive Republican.

\section{Dwight S. Jeffers}

Business address, United States Forest Service, Laramie, Wyo. Home address, Canon City, Colo.

Dwight Smithson Jeffers was born May 21, 1883, in Deland, Ill., the son of E. M. Jeffers, a clergyman, and Florence (Smithson) Jeffers. On his father's side he is of English and Scotch-Irish, and on his mother's of English ancestry. He has a brother, L. M. Jeffers, B.S. Illinois Wesleyan University.

He received the degree of B.A. from Illinois Wesleyan University in 1906. He spent the year of 1907-08 on United States reclamation work and during the year of 1909-Io was instructor in Canon City (Colo.) High School.

$\mathrm{He}$ is unmarried.

Since graduating from the Yale Forest School Jeffers has been forest assistant in the United States Forest Service with headquarters at Medicine Bow National Forest, Laramie, Wyo.

$\mathrm{He}$ is a member of the Methodist Episcopal church.

\section{Fred R. Johnson}

Business address, United States Forest Service, Halsey, Neb. Home address, 44 North Oak Street, Mt. Carmel, Pa.

Fred Runk Johnson was born January I9, I886, in Mt. Carmel, Pa., the son of Lloyd W. Johnson (died April Io, 1892), member of the 17th Pennsylvania Cavalry during the War of the Rebellion, I86I-65, and Susan (Miller) Johnson. On his father's side he is the grandson of Silas Johnson, and on his mother's of Henry Miller. $\mathrm{He}$ has three brothers: C. W. Johnson, D.D.S. University of Pennsylvania; S. H. Johnson, a graduate of Bloomsburg ( $\mathrm{Pa}$. ) State Normal School; and L. W. Johnson, Ph.B. Dickinson College '03, M.A. '05, and M.A. Harvard University 'o7; and three sisters: Nellie Johnson, B.A. Bucknell University, Mabel Johnson, B.A. Bucknell, and Martha Johnson. 
He received the degree of B.S. in Ig09 from Dickinson College, where he was a member of Phi Kappa Sigma.

He is unmarried.

Johnson entered the United States Forest Service July I, I9II, as forest assistant with headquarters in Arapaho National Forest, Colorado. On March I, 19I2, he was transferred to Nebraska National Forest, his present position.

In politics he is an Independent.

\section{Ernest F. Jones}

Business address, Sheridan, Mont. Home address, South China, Maine

Ernest Fuller Jones was born June 10, 1883, in China, Maine, the son of Frank Edward Jones and Luella Ermina (Graves) Jones. He has a brother, Harold W. Jones, B.A. Haverford College.

He was prepared at Moses Brown School and in 1907 received the degree of B.A. from Haverford College, after which he taught two years at Westtown School.

$\mathrm{He}$ is unmarried.

Upon graduating from the Yale Forest School Jones entered the United States Forest Service as forest assistant. He was later employed in the United States Indian Service for a time and then returned to the Forest Service, where his present headquarters are in Sheridan, Mont.

$\mathrm{He}$ is a member of the Friends' church.

\section{Otto Katz}

Business address, 153 West Twenty-third Street, New York City Residence, 30 East IIth Street, New York City

Otto Katz was born December 5, I889, in New York City, the son of Sigmund Katz and Elizabeth (Lederer) Katz, both born in Austria. He has a brother, Edwin Katz, and three sisters: Irma, Florence and Clara Katz.

He was prepared in the public schools of New York City and in 1909 received the degree of B.S. from the College of the City of New York.

$\mathrm{He}$ is unmarried. 
Since July, I9II, Katz has been general representative for the firm of Sigmund Katz, manufacturers of women's outer garments.

\section{Arthur F. Kerr}

Business address, United States Forest Service, Roseburg, Ore.

Home address, 956 Alder Street, Eugene, Ore.

United States Forest Service, Portland, Ore.

Arthur Frederick Kerr was born March I2, I884, in Rushmore, Minn., the son of William Kerr and Margaret (Thom) Kerr. He is of Scotch ancestry. He has a brother, Raymond E. Kerr, Ensign U. S. N. United States Naval Academy, and a sister, Winifred Kerr, a graduate of the University of Oregon and B.A. Simmons College.

Before entering the Forest School he spent three summers in the mountains of Oregon and two in Washington with the United States Coast and Geodetic Survey. He received the degree of B.A. from the University of Oregon in 1909.

He was married December 30, 1912, in Baker, Ore., to Miss Maude Service of Baker, Ore, daughter of Robert Service and La Vinne (Cole) Service.

Since graduating from the Yale Forest School Kerr has held the position of forest assistant in the United States Forest Service with headquarters on Umpqua National Forest, Roseburg, Ore.

In politics he is a Progressive Republican. He is a Free and Accepted Mason and at Yale was elected to Acacia Fraternity. $\mathrm{He}$ served six years in the Oregon National Guard and held a commission as second lieutenant.

\section{Eugene L. Lindsey \\ Business address, Clayton, Ga. Home address, Alexandria, $V a$.}

Eugene Lee Lindsey was born March I, 1890, in Alexandria, Va., the son of Noble Lindsey, president of the First National Bank of Alexandria and of the firm of N. Lindsey \& Company, and Catherine (Aitchison) Lindsey. He is of Scotch ancestry, being the grandson on his father's side of James Lindsey and on his mother's of John Aitchison of Renfrew, Scotland. He has three brothers: Wallace N. Lindsey, a graduate of Virginia Military Institute, Douglas and Allan Lindsey; and three sisters: Marian Lindsey, a graduate of Mary Baldwin Seminary, Mrs. O. H. Price 
and Mary E. Lindsey, both graduates of Randolph Macon Woman's College.

He graduated from the Virginia Military Institute in 1909.

$\mathrm{He}$ is unmarried.

Lindsey writes: "On July I, I9I I, was appointed field assistant on Jemez National Forest, New Mexico. On completion of Jemez reconnaissance I was transferred to Ozark National Forest, November I, I9II. On February I I obtained leave of absence for two months in order to prepare for examination for forest assistant in the United States Forest Service. I was reappointed April I as field assistant (under acquisition of land under Weeks bill) at Massanutten Area, Va., and on July I was promoted to field examiner on the same area." $\mathrm{He}$ has received an appointment as forest assistant under the new rules and will be stationed in the Appalachian Mountains.

He is a member of the Episcopal church.

\section{Thomas E. McCullough}

Business address, United States Forest Service, Flagstaff, Ariz. Home address, 124 West Twelfth Street, Davenport, Iowa

Thomas Edward McCullough was born January 28, I887, in Davenport, Iowa, the son of William J. McCullough, captain on the staff of the governor of Iowa, and Josephine (Mitchell) McCullough. His father was born in Bridgeport, Conn., the son of Thomas McCullough, who was born in Ireland, and his mother was born in Tennessee, daughter of Judge Nathanial Mitchell, whose wife was a cousin of the founder of Davenport, Iowa. He has three brothers: Gilbert F. McCullough, B.A. University of Notre Dame and M.D. Northwestern University '08; Henry M. and Richard Dorney McCullough; and two sisters: Mary Elizabeth and Rose A. McCullough, both graduates of St. Mary's College.

$\mathrm{He}$ was prepared at Davenport (Iowa) High School and in 1909 received the degree of B.C.E. from Iowa State College, where he was a member of Sigma Nu.

$\mathrm{He}$ is unmarried.

Since graduating from the Yale Forest School McCullough has been forest assistant in District 3 of the United States Forest Service. From July, I9I I, to March, I912, he was stationed in Cloudcroft, N. Mex.; from March to May, 1912, in the district office at Albuquerque, N. Mex., on detail; and from May, 1912, to the present time in Flagstaff, Ariz. 
$\mathrm{He}$ is a member of the Roman Catholic church and is a member of the Knights of Columbus.

\section{Samuel R. MacDonald}

Business address, R. F. D. I, Wallingford, Conn.

Home address, 171 Ravine Avenue, Yonkers, N. Y.

Samuel Rowley MacDonald was born May 10, 1886, in Newark, N. J., the son of Charles Howard MacDonald of the New York Stock Exchange and Fanny Stuart (Rowley) MacDonald. On his father's side he is of Scotch, and on his mother's of English ancestry. He has one brother, Howard Brenton MacDonald, and a sister, Theodora B. E. McCormick.

$\mathrm{He}$ was prepared at Columbia Institute and Barnard School in New York City, at the Yonkers High School, and spent a year in final preparation at Cutler School, New York City. In 1909 he graduated from the Sheffield Scientific School at Yale, where he was a member of Alpha Sigma Phi, of the Gun Club, the Freshman Glee Club, the University Orchestra, the Yale Masonic Club and the Orpheus Society. He was also a member of the New Haven Oratorio Society.

$\mathrm{He}$ is unmarried.

MacDonald is at present in the fruit business, having bought a peach orchard in Wallingford, Conn. He was formerly engaged in private forestry work in New York City. He writes: "Although a member of the Forest School Class of I9II, I did not go South until the following spring. In the interim, having passed the Civil Service, I received a temporary appointment as forest assistant in District I. Leaving the Service, I went to Bay Minette, Ala., in November and remained there in private forestry work until time to join the I9I 2 Class at Crossett, Ark."

In politics he is a Republican. He attends the Protestant Episcopal church. He is a member of Acacia, the New York Consistory, $32^{\circ}$, and subordinate masonic bodies, the Mystic Shrine and the Yale Club of New York City.

\section{A. Fletcher Marsh}

Business address, I605 McCormick Building, Chicago, Ill. Residence, I207 East Fifty-third Street, Chicago, Ill.

Allen Fletcher Marsh was born July 9, I888, in Chicago, Ill., the son of Charles A. Marsh, president of the Board of Trustees of the Uni- 
versity of Chicago Divinity School, and Lida (Shepardson) Marsh (deceased). He is the grandson of Professor Fletcher O. Marsh of Denison University, Granville, Ohio, and of Professor Daniel Shepardson. He has one sister, Helen (Marsh) McClintock.

He was prepared at the University High School, Chicago, Ill., at Andover and at Biltmore. In IgIo he graduated from the Sheffield Scientific School at Yale, where he was a member of the Freshman Track Team, the Sheff Student Council, Junior Reception Committee, Junior Fence Committee and Class Day historian.

He was married May 25, 1912, in New Haven, Conn., to Miss Margaret Dean Trowbridge of New Haven, Conn, daughter of Frank Dean Trowbridge, Yale ' 84 .

Marsh is secretary for the Marsh \& Truman Lumber Company of Chicago, IIl. He writes: "Started in business with Marsh \& Truman Lumber Company just as soon as I could get from Trinity, Texas, to Chicago and have been right at the desk since that time."

In politics he is a Progressive. He is a member of the Hyde Park Baptist Church of Chicago.

\section{Seward H. Marsh}

Business Address, United States Forest Service, Washington, D. C. Home address, Berea, $K y$.

Seward Hankins Marsh was born March 28, 1886, in Pawnee City, Neb., the son of Professor Miles Eugene Marsh, dean of the College Department of Berea College, Kentucky, and Katherine (Hankins) Marsh. He has a sister and two brothers, Elizabeth, Miles Eugene, Jr., and Wilson Marsh.

He was prepared at Berea Academy and before entering the Forest School received in 1909 the degree of B.A. from Berea College, where he was a member of the Football Team and of the Phi Delta Literary Society.

$\mathrm{He}$ is unmarried.

On graduation from the Forest School Marsh took a position which he still holds as forest assistant with the United States Forest Service. His assignment has been in District 2 in the Appalachian Forest.

He is a member of the Presbyterian church. 


\section{Frederick R. Mason}

Business address, United States Forest Service, Missoula, Mont.

Home address, Bound Brook, N. J.

Frederick Ramsey Mason was born May 17, I884, in Somerville, N. J., the son of William B. R. Mason and Rachel Manning (Townsend) Mason. His father has held the positions of manager and treasurer of the Bound Brook Water Company, postmaster of Bound Brook, president of the Bound Brook Building Loan Association, treasurer of the Firemen's Relief Association and of the New Jersey Editorial Association and editor of the Bound Brook Chronicle. He is of English ancestry. He has two brothers: David Townsend Mason, B.S. Rutgers '05, M.F. Yale ' 07 and M.S. Rutgers '08, and H. F. R. Mason.

In 1905 he received the degree of B.S. from Rutgers College, where he was a member of Chi Psi. From July, 1905, to October, 1906, he did clerical work in Bound Brook, N. J., and from that time until June, Ig08, was employed in the American Bank Note Company, New York City.

$\mathrm{He}$ is unmarried.

From October, I909, to September, I9I0, Mason worked in the J. \& J. Rogers Company, pulp and paper manufacturers, of Au Sable Forks, N. Y. Since July I, I9I I, he has been forest assistant in the United States Forest Service with headquarters in Missoula, Mont.

He is a member of the Congregational church.

\section{George Z. Mason}

Business address and residence, Collbran, Colo. IIo7 Forest Avenue, New York City

George Zachary Mason was born January 6, I889, in Kharkov, Russia, the son of Aaron Mason and Frieda Leah (Rits) Mason. He has five brothers: Morris A. Mason, M.D. New York University; Herman Mason, LL.B. New York University; Louis A. Mason, B.S. College of City of New York and LL.B. New York University; Ray E. Mason, B.A. Normal College of New York; and Gabriel R. Mason, B.S. College of City of New York and Ph.D. New York University.

He was prepared at DeWitt Clinton High School and Townsend Harris Hall Preparatory School and in 1909 received the degree of B.S. from the College of the City of New York, where he was a member of Omega Pi Alpha.

He is unmarried. 
Since graduating from the Forest School Mason has been forest assistant in the United States Forest Service with headquarters on Battlement National Forest, Colorado.

$\mathrm{He}$ is a member of the Jewish synagogue.

\author{
George R. Monell \\ Business address, Coos, N. H. \\ Home address, 1598 Lexington Avenue, New York City
}

George Roy [Gustave] Monell was born February 9, I889, in New York City, the son of Francis Gustave Monell and Amanda (Anderson) Monell. On his father's side he is of Swedish and English, and on his mother's of Swedish ancestry.

He received the degree of B.A. in 1909 from the College of the City of New York.

He is unmarried.

Upon graduation from the Yale Forest School Monell entered the United States Service as forest assistant. Since February, 1912, he has been assistant forester for the Connecticut Valley Lumber Company.

$\mathrm{He}$ is a member of the Unitarian church.

\title{
Albert E. Moss
}

Business address, 153 Huntington Street, New Haven, Conn. Home address, West Cheshire, Conn.

Albert Ernest Moss was born May 4, 1885, in Cheshire, Conn., the son of Joel William Moss and Julia Stowe (Hyde) Moss.

He graduated from the Connecticut Agricultural College in 1905.

$\mathrm{He}$ is unmarried.

Upon graduation from the Yale Forest School Moss entered the United States Service as forest assistant in District 3, working first on reconnaissance on Carson National Forest, New Mexico, then on sample plots on Jemez and Pecos National forests, New Mexico, and finally at the planting station, Las Gallinas Nursery, on Pecos National Forest. Since October, 1912, he has been assistant state forester of Connecticut with headquarters at the Connecticut Agricultural Experiment Station. 


\section{Harold S. Newins}

Business address, Oregon Agricultural College, Corvallis, Ore. Home address, Patchogue, N. Y.

Harold Stephenson Newins was born November 30, 1887, in Patchogue, N. Y., the son of Hiram DeWitt Newins, a sea captain, and Geraldine (Stephenson) Newins. His father's ancestors were New England farmers and his mother is of English descent. He has three brothers: Robert D., John Milton and Stanley Frost Newins, and a sister, Geraldine Newins.

He received the degree of $\mathrm{Ph} . \mathrm{B}$. in 1909 from Lafayette College, where he was a member of Phi Gamma Delta.

$\mathrm{He}$ is unmarried.

Since September, I9II, Newins has been instructor of forestry at the Oregon Agricultural College in Corvallis, Ore., and has been employed in the United States Forest Service during the summer months. $\mathrm{He}$ expects to spend next summer in the Cascade Mountains.

$\mathrm{He}$ is a member of the Congregational Church of Patchogue, N. Y.

\section{Douglas K. Noyes}

Business address, United States Forest Service, Yreka, Calif. Home address, 204 Highland Avenue, Orange, N. J.

Douglas Keefer Noyes was born June 2, I884, in New York City, the son of James Henry Noyes of Orange, N. J., manager of the Jewelers' Security Alliance, I5 Maiden Lane, New York City, and Regina Elizabeth (Keefer) Noyes. He is the grandson on his father's side of Gurdon W. Noyes, a Congregational minister, and Agnes (MacArthur) Noyes, a Scotchwoman. On his mother's side he is of German descent, being the grandson of Adam W. Keefer. He has one brother, Herbert MacArthur Noyes, Yale 'I4, and one sister, Ethel Regina Noyes. He has three uncles: Rev. Edward M. Noyes, Yale '79, Herbert L. Noyes, Yale ' 84 S., and Ernest C. Noyes, Yale '98. He is a descendant of Joseph Noyes, Yale 1709, and of Rev. James Noyes, who was chairman of the group of men who founded Yale in r7or.

He was prepared at Orange High School, Orange, N. J., studied a year with a private tutor and in 1907 graduated from Yale College, where he received the Pundit prize in his Sophomore year and a tuition scholarship.

$\mathrm{He}$ is unmarried. 
Noyes has been forest assistant in the United States Forest Service since graduating from the Forest School. His assignment has been in the Klamath National Forest, with headquarters at Yreka, Calif.

$\mathrm{He}$ is a member of the Congregational church, and in politics he is a Progressive Republican.

\section{Lawrence B. Pagter}

Business address, Care United States Forest Service, Sumpter, Ore. Home address, 8 Vernon Street, New Haven, Conn.

Lawrence Benjamin Pagter was born September 7, 1887, in New Haven, Conn., the son of Samuel S. Pagter, a cigar maker, and Florence F. (Greenbaum) Pagter. He has three brothers: Samuel S. Pagter, Jr., Amos T. Pagter, Yale 'II S., and Charles R. Pagter, Yale 'i6.

He was prepared at the Union High School, West Haven, Conn., and at the New Haven High School, and in 1909 was graduated from Yale College, where he received a high oration Junior and Senior philosophical appointment, and was a member of the Baseball Team.

He is unmarried.

Pagter is forest assistant in the United States Forest Service, with headquarters at Sumpter, Ore. He has been stationed at various times as forest assistant on the following National forests: Snoqualmie, Okanogan and Colville in Washington and Whitman in Oregon. He has been in the Government Service since July I, I9II.

\section{Ernest C. Pegg}

Business address, Iog Hitt Street, Columbia, Mo.

Home address, Fountain City, Ind.

Ernest Cecil Pegg was born February 5, 1888, in Fountain City, Ind., the son of William Pegg and Keturah Clementine (Shugart) Pegg. On his father's side he is of English, and on his mother's of German ancestry. He has a brother, Frank E. Pegg, and a sister, Nellie W. Pegg.

He spent three months timber estimating in Tennessee before entering the Forest School. He received the degree of B.A. from Wabash College in 1909. 
He was married August I, I9I2, in Crawfordsville, Ind., to Miss Ruth Amanda Hesler of Crawfordsville, daughter of Benton F. Hesler and Emma Hesler.

Upon graduation from the Yale Forest School Pegg entered the United States Forest Service as forest assistant with headquarters in Arizona and New Mexico, where he worked on timber sales, both reconnaissance and operation. Since September, 1912, he has been instructor in forestry at the University of Missouri.

He is a member of the Friends' church.

He has published: Woodlot for Central Indiana, Proc. Ind. Acad. of Sci., I9I0.

\title{
Edward C. M. Richards
}

\author{
Business address, Care Park Department of Borough of Queens, \\ New York City \\ Residence, IIO East Seventy-first Street, New York City
}

Edward Carrington Mayo Richards was born September 23, 1886, in Elizabeth, N. J., the son of Howard Richards, a retired lawyer, and Harriet (Mayo) Richards. On his father's side he is the grandson of Benjamin W. Richards of Philadelphia, Pa., and on his mother's side he is the great-grandson of Edward Carrington Mayo, Yale 18II, of Richmond, Va., and later of Elizabeth, N. J., and grandson of William C. Mayo, Yale 1852. He has one brother, Howard Richards, Jr., Yale 'oo S., E.E. Columbia '03, and two sisters, Adeline Mayo and Sarah L. Mayo.

He was prepared at the Gunnery, Lawrenceville and Salisbury schools, and in 1909 graduated from the Sheffield Scientific School at Yale, where he was a member of the Sheff Debating Society, of the Lawrenceville Club, of the University Swimming Team for three years and captain his Junior and Senior years, captain of the Igro Freshman Swimming and Water Polo teams and of the University Water Polo Team his Junior and Senior years and president of the Intercollegiate Swimming Association.

$\mathrm{He}$ is unmarried.

Richards is forester to the Borough of Queens, New York City. He entered upon his present position June 10, 1912. After graduation he worked for a while with the Cloquet Lumber Company, and later was district supervisor with the Pennsylvania Chestnut Blight Commission.

$\mathrm{He}$ is a member of the Protestant Episcopal church. 


\section{Abraham Rosenmond}

Business address, Hornblower \& Weeks, 42 Broadway, New York City Residence, 71 Lenox Avenue, New York City

Abraham Rosenmond was born March 30, 1889 , in Cincinnati, Ohio, the son of Samuel Rosenmond and Yetta (Eisner) Rosenmond. $\mathrm{He}$ has six brothers and sisters: Meyer H., David, Ray, Mollie, Edith and Nellie Rosenmond.

He received the degree of B.S. from the College of the City of New York in 1909.

$\mathrm{He}$ is unmarried.

Upon graduation from the Yale Forest School Rosenmond entered the United States Forest Service as forest assistant. Since January 15, 1912, he has been clerk in the firm of Hornblower \& Weeks of New York City.

$\mathrm{He}$ is a member of the Jewish synagogue.

\section{Harold L. Russell}

\section{Business address, United States Forest Service, Appalachian Division,} Washington, $D . C$.

Residence, Radnor Avenue, Govans, Baltimore County, Md.

Harold Louis Russell was born August 24, 1883, in Auburn, Cayuga County, N. Y., the son of L. Marcus Russell and Helen Minnis (Spoor) Russell. On his father's side he is of English, and on his mother's of English and German ancestry. His ancestors on both sides of the family were New York State farmers. He has a brother, Howard William Russell, a graduate of the Y. M. C. A. Training School of Springfield, Mass., now at the Y. M. C. A. in Detroit, Mich., and a sister, Bertha Louise Russell, a graduate of the Maryland State Normal School, now a teacher in Baltimore, Md.

He attended the public schools of Baltimore, Md., graduated from the Maryland State Normal School in I90I and from that time until I904 taught manual training in Annapolis, Md. From 1902 to 1906 he studied mechanical drawing with night classes at the Maryland Institute, Baltimore, Md., graduating in 1906; attended the Deichmann College Preparatory School, Baltimore, from 1904 to 1906 ; and in 1909 received the degree of B.A. from Johns Hopkins University.

$\mathrm{He}$ is unmarried.

Since graduating from the Yale Forest School Russell has been employed in the United States Forest Service as forest assistant. From June to November, I9I I, he was stationed on 
Potomac Area; during November and December of I9II on Natural Bridge Area; from January to April, I912, on Georgia Area; and from May, 1912, to the present time on Shenandoah Area, Maryland.

$\mathrm{He}$ is a member of the Methodist Episcopal church.

\section{John W. Spencer}

Business address, Garniers, Fla.

Home address, Emporia, Kans.

John William Spencer was born December 4, 1887, in Cawker City, Kans., the son of Samuel Schaffer Spencer, a lawyer and formerly county attorney of Lyon County, Kansas, and Ida Florence (Zimmerman) Spencer. His father is the son of a Methodist minister and was born in Columbus, Ohio, being of German and Irish ancestry. His mother was born in Springfield, Ohio, and is of German descent. He has three sisters: Dorothy Spencer, a graduate of the Kansas State Normal School, Ruth and Louise Spencer; and two brothers: Robert and Ober Spencer.

In 1909 he received the degree of B.A. from the College of Emporia, where he was manager of the college paper and annual and was a member of the debating team for three years.

He was married April 28, I9I2, in Cawker City, Kans., to Miss Blanche Olive Higley of Cawker City, daughter of Curt Mason Higley and Etta (Mayer) Higley.

Upon graduation from the Yale Forest School Spencer entered the United States Forest Service as forest assistant. He writes: "Was engaged in cruising timber and surveying on Carson National Forest, New Mexico, during the summer and fall of 19I I. Since then have been permanently assigned as assistant on Florida National Forest."

In politics he is a Progressive Republican. He served two years (1906-07) in the Kansas National Guard and is a member of the Ancient Order of United Workmen.

\section{Louis R. Stadtmiller}

Business address, Bureau of Forestry, Manila, P. I. Home address, 429 Atlantic Street, Stamford, Conn.

Louis Roemmer Stadtmiller was born January 29, 1887 , in New Haven, Conn., the son of Henry Roemer Stadtmiller, who took a special course in the Scientific School in I879-80, a mechanical engineer, and Alice $\mathbf{M}$. 
(Weckesser) Stadtmiller. He is of German ancestry, being the grandson on his father's side of L. R. Stadtmiller and on his mother's of L. Weckesser. He has three sisters: Alvina, Dorothy and Henrietta Stadtmiller. He has an uncle, Louis W. Stadtmiller who took a special course in the Sheffield Scientific School in 1879-80, and a cousin, Kar] C. Stadtmiller, Yale 'og S.

He was prepared at the Waterbury High School and in I9Io received the degree of Ph.B. from the Sheffield Scientific School at Yale, where he was a member of Berzelius.

$\mathrm{He}$ is unmarried.

Stadtmiller is district forester in the United States Forest Service with headquarters at Manila, P. I. He has held this appointment in the Moro district since August 12, I9II.

$\mathrm{He}$ is a member of the Army and Navy Club of Zamboanga and the Mindanao Club.

\section{J. Warrington Stokes}

Business address, United States Forest Service, St. Anthony, Idaho Home address, Holmesburg, Philadelphia, $\mathrm{Pa}$.

Joseph Warrington Stokes was born October 20, 1886, in Darlington. Md., the son of Horace Stokes and Helen (Stokes) Stokes. He is the grandson on his father's side of Joseph Stokes and Mary (Warrington) Stokes of Morristown, N. J., and on his mother's of Samuel E. Stokes and Mary (Kempton) Stokes of Philadelphia, $\mathrm{Pa}$. $\mathrm{He}$ has a sister. Elizabeth Kempton Stokes.

He received the degree of B.S. in 1909 from Haverford ( $\mathrm{Pa}$.) College.

$\mathrm{He}$ is unmarried.

Upon graduation from the Yale Forest School Stokes entered the United States Forest Service as forest assistant with headquarters in Ogden, Utah. He has lately been transferred to Targhee National Forest, St. Anthony, Idaho.

$\mathrm{He}$ is a member of the Episcopal church.

\section{Myron W. Thompson}

Business address, United States Forest Service, Cody, Wyo.

Home address, Halifax, Mass.

Myron Wood Thompson was born March 5, 1887, in Halifax, Mass., the son of Jabez P. Thompson, member of the Massachusetts state legis- 
lature three years and holder of various town offices, and Abbie Parker (Wood) Thompson. He has a brother, Clifford B. Thompson, B.S. Massachusetts Agricultural College '07, and two sisters: Helen L. Thompson, a graduate of Bridgewater (Mass.) Normal School, and Bertha A. Thompson.

He was prepared at the Bridgewater (Mass.) High School and in I909 received the degree of B.S. from the Massachusetts Agricultural College, where he was a member of Phi Sigma Kappa and various clubs and had four years of military drill, being adjutant his Senior year.

$\mathrm{He}$ is unmarried.

Since graduating from the Forest School Thompson has been forest assistant in the United States Forest Service with headquarters in Shoshone National Forest, Wyoming. He writes: "After leaving Texas in June, I9I I, traveled through the Middle West, arriving in Denver, Colo., on July $\mathbf{I}$. Then went to Cody, Wyo, and have since been traveling over the country adjacent to the Yellowstone National Park on the east."

$\mathrm{He}$ is a Progressive Republican.

\section{Robert E. Thompson}

Grand Rapids, Mich.

Robert Elmer Thompson received the degree of B.S. at Michigan Agricultural College in 19ro. He has not furnished any information for this record.

\section{Sidney H. Thompson}

Business address, United States Forest Service, Washington, D. C. Home address, 47 Summer Street, St. Johnsbury, Vt.

Sidney Hammond Thompson was born March 29, 1887, in Irasburg, Vt., the son of Laforrest Holman Thompson (died in June, 1900) and Helen (Kinney) Thompson. His father was state's attorney in 1874-75, judge of probate in 1876 and $188 \mathrm{I}$, twice a member of the Vermont state legislature, senator from Orleans County, Vt., in 1884 , and judge of the supreme court from I89I until his death. On his father's side he is of Scotch-Irish ancestry, being the grandson of Rev. Levi S. Thompson and Irene (Hodgkins) Thompson, and on his mother's side of Welsh and Scotch descent, the grandson of Hammond Kinney and Amanda (Edson) Kinney. He has two sisters: Margaret (Thompson) Sylvester and Helen (Thompson) Smith; and two brothers: Frank Dutton Thomp- 
son, a graduate of the Boston Law School in 1899, and Philip Laforrest Thompson, B.S. Dartmouth '08, and C.E. ' 09 .

He received the degree of B.A. in 1909 from Dartmouth College, where he was a member of Phi Delta Theta and of Sphinx Senior Society.

He was married October 3, 1912, in St. Johnsbury, Vt., to Miss Hortense Peters of St. Johnsbury, Vt., daughter of Dr. George Frederick Cheney and Emma (Smith) Peters Cheney.

Since July I, I9II, Thompson has been employed in the United States Forest Service as forest assistant with headquarters in Washington, D. C. He has been engaged in the examination of land under the Weeks law in West Virginia and Virginia.

In politics he is a National Progressive.

\section{Charles H. Watzek}

Business address, Crossett Western Lumber Company, Wauna, Ore. Home address, 1407 Brady Street, Davenport, Iowa

Charles Harlan Watzek was born July 3, 1887, in Davenport, Iowa, the son of John Wentzel Watzek and Helen Theresa (Harlan) Watzek. On his father's side he is of Austrian, and on his mother's of direct Puritan descent. He has two brothers: Aubrey Richardson Watzek, Yale 'o9, and John Whittier Watzek, Yale 'r3 S.

He was prepared at the high school in Davenport, Iowa, and at Andover, and in 1910 graduated from the Sheffield Scientific School at Yale, where he was a member of Sigma Xi, of the Executive Board of the Sheff Y. M. C. A. and of the City Government Club. He also received general honors in his Junior year, was Class Deacon and President of the Iowa Club and engaged in industrial work.

His engagement has been announced.

Watzek held various minor positions in southern yellow pine manufacturing lumber plants during I9II-I2. He spent three months in the summer of I9I I automobiling through England and Continental Europe. Since June I, I912, he has been connected with the Big Creek Logging Company of Portland, Ore., as secretary and treasurer. In addition to this he has recently become secretary and treasurer and assistant manager of the Crossett Western Lumber Company of Wauna, Ore.

$\mathrm{He}$ is a member of the Episcopal church. Hè is Secretary of the Class of rgir, Yale Forest School. 


\section{Non Graduates}

\section{Charles E. Beaumont}

Business address, United States Forest Service, Washington, D. C. Home address, Rocky Hill, Conn.

Charles Elliott Beaumont was born September 13, I886, in Rockville, Conn., the son of Charles Beaumont, who is engaged in the real estate business, and Ellen (Skinner) Beaumont. On his father's side he is of French ancestry, being the grandson of C. G. Beaumont and Mary (Pratt) Beaumont. His mother's ancestors came from England about 1630 and settled in Windsor and Hartford. Her parents were L. T. Skinner and Mari (Wolcott) Skinner. He has two brothers: Clayton G. and Arthur L. Beaumont, and a sister, Bertha O. Beaumont.

He was prepared at the New Haven High School and in 1909 received the degree of $\mathrm{Ph} . \mathrm{B}$. from Yale.

$\mathrm{He}$ is unmarried.

Beaumont writes: "In the summer of I9Io I had a position as field assistant in the United States Forest Service on Stanislaus National Forest, California. Was appointed forest assistant on the Pike National Forest, Colorado, from July I, I9II, to October I, I9II. I was then transferred to the Appalachians and have been examining lands under the Weeks Law in Georgia, North and South Carolina."

$\mathrm{He}$ is a member of the Congregational church and in politics is a Progressive.

\section{Roger B. Briggs}

Business address, Care New York, New Haven \& Hartford Railroad Company, New Haven, Conn.

Home address, Broad Street, Stratford, Conn.

Roger Beach Briggs was born September 2I, I889, in Bridgeport, Conn., the son of Warren R. Briggs, director of the American Institute of Architects and president of the Connecticut Chapter, treasurer of the Architectural League of New York and author of "Modern American School Buildings," and Eliza (Hawley) Beach. His father's parents were E. E. and M. G. Briggs, and his mother's were George E. Beach and Mary A. (Edmund) Beach. He has a sister, Marjory Beach Crane.

He attended the Connecticut Agricultural College in I909, where he took part in athletics.

$\mathrm{He}$ is unmarried. 
From January, 1910, to June, 1912, Briggs was employed by the American Tube \& Stamping Company of Bridgeport, Conn. He then went to Vermont for three months on account of illhealth, at the end of which time he became inspector for the New York, New Haven \& Hartford Railroad Company, his present position.

$\mathrm{He}$ is a member of the Stratford Congregational Church and is also a member of the University Club of Bridgeport, Conn., and the Cupheag and Housatonic Yacht clubs of Stratford, Conn.

\section{Sydney F. Brown \\ 83 Prospect Street, Reading, Mass.}

Sydney Freeman Brown was born February 4, 1888, in Reading, Mass., the son of Charles Freeman Brown, formerly member of the Massachusetts House of Representatives and Senate and chairman of the District Republican Committee, and Elizabeth Anna (Harrison) Brown. On his father's side he is of English and Scotch, and on his mother's of English and Dutch ancestry. He has a sister, Gertrude C. (Brown) Pahlow, and a brother, Arthur H. Brown, B.S. Massachusetts Institute of Technology '99.

He was prepared at the public schools in Reading, Mass., and at Phillips Andover and in 1910 received the degree of Ph.B. from Yale, where he was a member of Chi $\mathrm{Phi}$ and of the Andover and Corinthian Yacht clubs. He also rowed on the I9II Sophomore Crew and in his Senior year was a member of the Sheff Student Council and of the Class Book Historian Committee.

$\mathrm{He}$ is unmarried.

Brown writes: "Worked in a printing house from the summer of I9Io to the spring of I9I I and from this time until the fall of I912 with Little, Brown \& Company, book publishers. Am now with the Oxford County Orcharding Company of South Paris, Maine, as treasurer and general manager. We have an apple orchard of about one thousand trees, of which five hundred are in bearing, and in addition have over a hundred acres of orchard land and great possibilities. Expect to be in the apple business until demented or otherwise incapacitated."

Concerning politics he writes: "Am a member of the Republican party in general, but will vote the Democratic national ticket this year." He is a member of the Meadow Brook Golf Club. 


\section{Philip L. Buttrick}

Business address, Care of J. S. Holmes, Chapel Hill, N. C. Home address, Orange, Conn.

Philip Laurence Buttrick was born June 25, 1886, in New Haven, Conn., the son of Willis Nathan Buttrick, a descendant of William Buttrick of England who settled in Concord, Mass., about 1630, and Mary Willian (Cannon) Buttrick, descended from French Huguenots who settled in America about 1680 . He has a brother, Nathan LeGrand Buttrick.

He was prepared at the New Haven High School, spent two years with the Class of 'og S., from Igog to I9r I did special work at the Sheffield Scientific School at Yale and in I9I0-II was in the Forest School. He worked for a short time before entering the Forest School for the Great Northern Paper Company.

$\mathrm{He}$ is unmarried.

After leaving the Forest School Buttrick became forest assistant in the United States Forest Service and later was forester for the Lanphere Heinrich Company. In June, 1912, he was appointed field agent for the New Haven Anti-Mosquito Committee, Inc. Since November I, I912, he has been engaged in the commercial and silvicultural survey of the chestnut for the State Geological Survey of North Carolina.

In politics he is "Independent with Democratic leanings."

He has published: List of birds of New Haven, Section on water birds, Publications of the New Haven Bird Club, New Haven, May, I908; and Effects of fire on trees and reproduction in southern New England, For. Quart., June, I912.

\section{Charles H. Edwards}

Business address, Bishop, Calif.

Home address, 169 Montezuma, Houghton, Mich.

United States Forest Service, Washington, D. C.

Charles Herbert Edwards was born August II, 1885, in Houghton, Mich., the son of James P. Edwards and Agnes M. (Mulvey) Edwards. On his father's side he is of English, and on his mother's of Irish ancestry. He has a brother, Richard J. Edwards, a graduate of Michigan Agricultural College and the University of Wisconsin.

He received the degree of B.S. from the Michigan Agricultural College in 1909. He was registered at the Yale Forest School in I9IO-II.

$\mathrm{He}$ is unmarried. 
Edwards entered the United States Forest Service in August, I909, as forest guard, and later as forest agent on Kootenai National Forest, Libby, Mont., and in April, I910, was appointed assistant ranger. He had charge for a time of a timber reconnaissance crew on Helena National Forest and in I9I I was a member of a similar crew on Deerlodge National Forest, Montana. On October I, I9II, he became forest assistant and since I9I2 has been stationed on Inyo National Forest, California.

$\mathrm{He}$ is a member of the Roman Catholic church and belongs to the American Forestry Association.

\section{W. Irving Gilson}

Business address, East Lansing, Mich.

Home address, 59 North Main Street, Adrian, Mich.

W. Irving Gilson was born February 27, 1888, at Deerfield, Mich., the son of William Gilson, a farmer, and Catherine E. (Howland) Gilson. His father's parents were Cornelius Gilson, son of a New York farmer, and Esther Gilson, daughter of a Pennsylvania farmer. His mother was the daughter of Charles E. Howland, who studied at Cincinnati Medical College, formerly of New York State, and Emily Howland, daughter of a Pennsylvania farmer. He has a brother, Clarence Gilson, and a sister, Alice Gilson.

He received the degree of B.S. from Michigan Agricultural College in 1910. His summers were spent in farming until 1909, after which they were spent in the United States Forest Service. He was registered at the Yale Forest School during the fall term, 1910-rr.

$\mathrm{He}$ is unmarried.

Gilson served as forest assistant in the United States Forest Service during the summer of I9I0. On January I, I9II, he left the Forest School and became instructor of forestry at the Michigan Agricultural College, his present position. He has spent his summers as forest assistant in the Forest Service. He writes: "During summer of I9II was stationed on Jemez National Forest, New Mexico, and in September took a trip through the Grand Cañon. In December, I9II, went with Senior students to the lumber camp at Millville, Ark., and thence to New Orleans. Taught a course in field methods at the Forestry Summer School, Vanderbilt, Mich., in June, I912." 
$\mathrm{He}$ is a member of the Methodist church. Concerning politics he writes: "My politics are uncertain now, but because of my interest in forestry I am in favor of men as political leaders who are most interested in conservation policies." He is a member of the Masonic Order, the Highland Teachers Club of East Lansing, Mich., and of the Athenæum Literary Society.

\section{Richard H. Goode}

Business address, 382 Atlantic Avenue, Boston, Mass. Home address, 30 Brastow Avenue, Somerville, Mass.

Richard Henry Goode was born September II, I883, in Boston, Mass., the son of Richard Young Goode, manager and partner in the firm of A. Wheeler \& Company, dealers in paints, and Mary Anne Goode. His father has held the positions of ward alderman and alderman-at-large of Somerville, Mass., vice president of the Somerville Board of Trade, master of the American Order of Union Workers and member of the official board of the Methodist Episcopal church and is a Mason and an Odd Fellow. He has a sister, Eva M. Goode, who attended Dr. Sargent's Physical Culture School for Girls, and two brothers, W. T. Goode, salesman of paints, bronze, etc., and A. J. Goode, wholesale jeweller.

He was prepared at the Somerville (Mass.) Latin School and in 1907 received the degree of B.A. from Dartmouth College. In 1908 he taught grammar school and was tree doctor of Somerville and in 1909 he was athletic director of Middlebury College and did some tree doctoring. He was registered in the Yale Forest School in 1909-IO.

$\mathrm{He}$ is unmarried.

Goode was forest assistant in the United States Forest Service for six months in I9II, after which he resigned. He has since held the positions of draftsman for the Northern Contracting Company of Atlanta, Ga., consulting forester and land agent in Atlanta, lumper and tally-man for the A. T. Stearns Lumber Company of Neponset, fire damage reporter for Fisher \& Bryant of Boston, Mass., and has done rough surveying in Georgia. On June I2, I9I2, he was appointed assistant supervisor in utilization of the Pennsylvania State Chestnut Tree Blight Commission. He has lately opened an office in Boston and is prepared to handle appraisals, maps, legal rights, operating and market advice, fire 
damage and forestry work of all kinds. In 1912 he received the degree M.S.F. from the University of Michigan.

He has written several newspaper articles.

\section{Raymond W. Gowdy \\ Thompsonville, Conn.}

Raymond Willis Gowdy was born July 20, I889, in Thompsonville, Conn., the son of Willis and Nellie (Peters) Gowdy.

He was prepared at Phillips Academy, Exeter, N. H., and received the degree of $\mathrm{Ph} . \mathrm{B}$. at Yale in 1910. He attended the Forest School during I9I0-II.

He is unmarried.

Gowdy spent the winter of I9I2-I3 on his grapefruit farm at Santa Barbara, Isle of Pines, Cuba.

\section{James H. Hull}

Business address, Targhee National Forest, St. Anthony, Idaho 315 South Main Street, Torrington, Conn.

James Howard Hull was born September 20, 1881, in Southington, Conn., the son of Lewis C. Hull and Frances Reynolds (Hinman) Hull. His father is the son of Daniel Hull of Southington, Conn., and a descendant of Richard Hull, who settled in New Haven Colony in 1636. His mother's family lived in New Haven, Conn. He has seven brothers: Albert W. Hull, B.A. Yale '05 and Ph.D. 'o9, Daniel Raymond Hull, Ph.B. Yale 'II, Edwin L., Walter H., Caleb S., Thomas G., Yale '13 S., and John B. Hull.

In 1907 he received the degree of B.A. from Yale and was registered in the Forest School during 1909-10.

$\mathrm{He}$ is unmarried.

Hull entered the United States Forest Service in July, I910, as forest guard with headquarters on Nezperce National Forest, Idaho. In July, I91 I, he became field assistant and forest ranger on Boise National Forest, Idaho, and since July, 1912, he has been forest assistant, being stationed at present on Targhee National Forest, Idaho.

Concerning politics he writes: "I try to vote for men of good principles and sound judgment, but I don't like to subscribe to any political creed now existing. Such creeds are seldom free from idiotic derisible fallacies!" $\mathrm{He}$ is a Mason. 


\section{John Lautz}

Business address, Munson Steamship Line, 82 Beaver Street,

New York City

Home address, 384 DeWolfe Place, Hackensack, N. J.

John Lautz was born March 3, 1888, in Buffalo, N. Y., the son of Martin F. Lautz and Elizabeth Marie (Bank) Lautz. He has a brother, Martin W. Lautz.

He was prepared at the Master Park High School, Buffalo, N. Y., and afterwards attended Colgate University. In I9Io he received the degree of Ph.B. from Yale, where he was a member of Delta Upsilon.

He was married July I4, I9I0, in Syracuse, N. Y., to Miss Laura Lyon Tobin of Syracuse, daughter of William N. Tobin and Teresa Frances (Lyon) Tobin. They had a daughter, Laura Lautz, born August 9, r91 I, in Flemington, N. J., who died December 19, I9II, in New York City.

In the year I9I0-I I Lautz was engaged in farming and in I9I I in selling pottery. Since February I, I912, he has been clerk in the Cuban department of the Munson Steamship Line, New York City.

$\mathrm{He}$ is a member of the Episcopal church and in politics is NonPartisan, against Roosevelt and for free trade.

\section{Elmer B. Mason}

Business address, Bureau of Entomology, Washington, D. C. Residence, 926 B Street, S. W., Washington, D. C.

Elmer Brown Mason was born September 30, 1880, in Deer Lodge, Mont., the son of Captain Roswell Henry Mason, surveyor general of Montana, captain in the $72 \mathrm{~d}$ Illinois in the Civil War and recorder of the Illinois Commandery of the Loyal Legion, and Mary (Brown) Mason of Rome, N. Y. His grandfather was the Hon. R. B. Mason, mayor of Chicago at the time of the Chicago fire and builder of the Illinois Central Railroad. He is of French and English ancestry. He has a brother, Roy M. Mason, B.A. Yale '02.

$\mathrm{He}$ prepared at the University School in Chicago, and abroad. He attended Yale College from 1898 to 1900 . He received the degree of B.A. from Princeton in 1903 and before entering the Yale Forest School was engaged in the real estate business, in literary work and in lumbering. He was registered at the Yale Forest School from 1909 to 1910.

$\mathrm{He}$ is unmarried. 
Since leaving the Forest School Mason has been entomological assistant in the branch of forest insects of the United States Bureau of Entomology, in charge of the South Atlantic and Gulf states. He writes: "Was in charge of forest insect field station at Spartanburg, S. C., from August 20, I9I I, until the closing of the station, December I5, I9I I. Went there as last man and came away in charge. Since then have been engaged in editorial and investigating work in Washington with frequent trips through the South and attendance at meetings of various kinds to speak on the southern pine beetle."

In politics Mason is a Democrat. He served in the Spanish War as second lieutenant of Company B of Colonel Koch's regiment of United States Provisional Volunteers. He is a member of the Princeton Club and of the Society of Economic Entomology.

He has published stories in various magazines, sixty-eight articles in newspapers, and forty-nine addresses delivered from New Orleans to Raleigh, N. C., in lumber journals and newspapers, and an address before Forestry Convention at Raleigh, N. C., published as bulletin of North Carolina Geological and Economic Survey.

\section{Harry Olin}

Rush City, Minn.

Harry Olin was born August 21, 1887, in Okemos, Mich., the son of John Henry Olin, a merchant, and Eva (Tyler) Olin. His father is of Welsh ancestry and has been city treasurer and a member of the school board.

He was prepared at the Okemos (Mich.) High School and in roro received the degree of B.S. from Michigan Agricultural College, where he was a member of Phi Delta.

He was married August 21, I911, in Lansing, Mich., to Miss Clara Mary Brisbin of Lansing, daughter of Frank C. Brisbin (died in 1889).

Since September, I9II, Olin has been an instructor in agriculture at the Rush City (Minn.) High School.

$\mathrm{He}$ is a member of the Episcopal church and also of the Masonic Order and the Independent Order of Odd Fellows. 


\title{
Earl S. Peirce \\ Business address, Denver, Colo. \\ Home address, Frankfort, Maine
}

Earl Stanley Peirce was born September 26, 1887, in Frankfort, Maine, the son of George Peirce and Emma (Patten) Peirce. He is of English ancestry. He has a brother, Albert Peirce, and two sisters: Ruth Peirce and Christine Peirce, B.A. Vassar 'o7.

He was prepared at Peekskill (N. Y.) Military Academy and at Phillips Andover, where he was a member of Phi Delta Sigma, and in 1909 received the degree of Ph.B. from Yale, where he was a member of Chi Phi. He was registered at the Forest School during 1909-10.

$\mathrm{He}$ is unmarried.

On July I, I9I0, Peirce was appointed forest assistant in the United States Forest Service, being stationed on Bighorn National Forest, Wyoming. In January, I9I3, he was transferred to the district office at Denver as deputy forest supervisor. In April he returned to the Bighorn National Forest.

$\mathrm{He}$ is a member of the Unitarian church.

\author{
Archer E. Roberts \\ Business address, United States Forest Service, Yreka, Calif. \\ 97 Fern Street, Hartford, Conn.
}

Archer Egbert Roberts was born December 17, 1883, in New York City, the son of John Thompson Roberts and Carrie (Egbert) Roberts. He has a sister, Mrs. Henry F. Stoll.

He was prepared at Hotchkiss School, Lakeville, Conn.

$\mathrm{He}$ is unmarried.

From November, I9Io, to May, I9II, Roberts was a tutor in Aiken, S. C. He entered the United States Forest Service in July, I9II, and was located in Sandpoint, Idaho, until October, I9I I. Since May, I9I2, he has been stationed at Yreka, Calif.

\section{Kurt Roehrs \\ Roswell, N. Mex.}

Kurt Roehrs was born January 2, 1885 , in Jersey City, N. J., the son of Julius Roehrs and Margaret (Schroeder) Roehrs. 
He was prepared at Stevens School and at Stevens Institute of Technology and in 1910 received the degree of $\mathrm{Ph} . \mathrm{B}$. from Yale.

He was married December 18, 1912, in Roswell, N. Mex., to Miss Fern Leta Olp of Lake Geneva, Wis., daughter of H. C. Olp.

Roehrs is at present engaged in agriculture in Roswell, N. Mex.

\section{Robert Stephenson}

\section{Bank Street, New York City}

Robert Stephenson was born August 9, 1887, in Tabor, N. J., the son of William Pritchard Stephenson and Sarah Anne (Hawks) Stephenson. $\mathrm{He}$ is of English ancestry and his mother's ancestors were Quakers.

He attended Rutgers College two years and in 1909 received the degree of B.A. from Columbia University, where he was a member of Delta Upsilon. He was registered at the Yale Forestry School during 1909-10.

$\mathrm{He}$ is unmarried.

From June I5, I9I0, to April 12, I9I I, Stephenson was field assistant in the United States Forest Service and from May r, I9I I, to February 6, I9I2, he was connected with the Laurentide Paper Company, forestry division. He was employed by the state forester of Connecticut from February I2 to May 21, I912, and was assistant topographer of the Yale Peruvian Expedition, May 13, 1912, to February 13, 1913.

\section{Frederick W. Toerner 758 East I6oth Street, New York City}

Frederick William Toerner was born March 9, r882, in New York City. He received the degree of B.A. from the College of the City of New York in 1902 and was an ex-member of the class of I9I0, Sheffield Scientific School. He attended the Yale Forest School in 1909-10. He has furnished no information for this record.

\section{Richard W. Walker Glenmore, $\mathrm{Pa}$.}

Richard Washington Walker was born February 22, I864, in Chester County, Pa., the son of Samuel Lafayette Walker and Ann Aurelia 
(Strickland) Walker. His father's parents were Richard Walker, son of Captain William Walker, and Sarah (Henderson) Walker, and his mother's were Jesse C. Strickland, M.D., and Martha (Wollerton) Strickland, daughter of William Wollerton and Rebecca (Harvey) Wollerton. He has a sister, Anna Martha Walker, B.A. Bryn Mawr '95 and M.A. Leland Stanford, Jr., University 'or.

He received the degree of C.E. from Lehigh University in 1884 and was a graduate student in education at Leland Stanford, Jr., University from January 9 to April 18, 1906, and from January to June, 1907. He was registered at the Yale Forest School during I909-II.

He was married October 3, 1899, in Washington, D. C., to Miss Olivia Virginia Durnall, daughter of Milton Durnall, M.A., and Phoebe Ann (Baily) Durnall.

Walker writes: "Was temporary aide for the United States Coast and Geodetic Survey during the summers of I882 and I883, and from June to November, 1884, was employed on primary triangulation in Pennsylvania. Was assistant engineer in Guatemalan Boundary Survey with Mexico from December I, I884, to May I2, 1896; assistant engineer in Darien Survey under Isthmian Canal Commission from December I, 1899, to June 4, 1900; draftsman in United States Coast and Geodetic Survey from November 26, 1900, to April, I90I, and magnetic observer afterwards in Washington, D. C., until April I, I903. From May 2I, 1906, to January 13, 1907, served as forest student in the United States Forest Service in California and from July to September, 1908, traveled with my wife in the Yosemite Valley, California. Was field assistant on Colorado National Forest from July I to September I5, I9I I."

$\mathrm{He}$ is a member of the Presbyterian church and in politics is a Republican. He is a member of the National Geographic Society. 


\title{
CLASS OF 1912
}

Graduates holding Degree of M.F.

\author{
William R. Barbour \\ Business address, Andrews, N. C. \\ Home address, 420 Hyde Avenue, Ridgway, Pa.
}

William Richard Barbour was born June 9, 1890 , in Ridgway, $\mathrm{Pa}$., the son of William Washington Barbour and Helen (Little) Barbour. On his father's side he is of Scotch-Irish, and on his mother's of English descent. His father was at different times a school teacher, a professor of mathematics and a lawyer. He has two brothers: Dana Little Barbour, a student at Cornell, and Carroll Bartlett Barbour, and one sister, Lucy Elizabeth Barbour.

He was prepared at the high school in Ridgway, $\mathrm{Pa}$., and graduated from Andover Academy in 1908. In I9II he graduated from the Sheffield Scientific School at Yale.

$\mathrm{He}$ is unmarried.

Barbour is forest assistant in the United States Forest Service with headquarters at Andrews, N. C. He has been in the Service since July I, I912. He writes: "Since the end of spring term of school, which was spent at Crossett, Ark., have been working for the Forest Service in the Smoky Mountains in the extreme southwestern part of North Carolina, at the head of Nantahala River, in Cherokee and Macon counties. This area is known as 'Nantahala.' Am engaged in reconnaissance work (examination of lands proposed for sale to the government). This is a fine country, altitude being from 4,500 to 6,000 feet, very healthy, but hard to travel. No railroads close, roads poor. The timber is mostly virgin, consisting of chestnut, oaks, hickory, poplar and hemlock. The region will make one of the best reserves in the East. About thirty thousand acres are now taken up by the government."

$\mathrm{He}$ is a member of the Presbyterian church. 


\section{Victor A. Beede}

Business address, Care Forest Service, Pike National Forest, Denver, Colo.

425 Temple Street, New Haven, Conn.

Victor Augustus Beede was born December 9, I886, in East Braintree, Mass., the son of Frank Herbert Beede, Yale ' 83 , superintendent of public schools, New. Haven, Conn., and Caroline May (Coan) Beede. On his father's side he is of Welsh, and on his mother's of English ancestry. He has one sister, Faustina Knowlton Beede.

He was prepared at the New Haven High School and at Hopkins Grammar School, New Haven, and served one winter in Porto Rico as apprentice in the Red " $D$ " steamship office. In I9Io he graduated from Yale College, where he was a member of Zeta Psi.

He was married June 26, 1912, in Woodmont, Conn., to Miss Ella Small of New Haven, Conn., daughter of Charles Small and Adeline (Kiefer) Small.

For several months after graduation Beede traveled in Europe and in the late fall of 1912 became forester and assistant secretary for the Massachusetts Forestry Association. He is now in the Government Service, being stationed on the Pike National Forest, Denver, Colo.

$\mathrm{He}$ is Secretary of the Class of I9I2, Yale Forest School.

\section{Henry J. Bothfeld}

450 Ovington Avenue, Brooklyn, N. Y.

Henry Julius Bothfeld was born August 30, I886, in Bay Ridge, N. Y., the son of F. Otto Bothfeld, who is in the commission business in New York City, and Clara (Heiniglse) Bothfeld. He has a brother and a sister: Rudolf Otto Bothfeld and Anna M. M. Bothfeld.

He was prepared at the Polytechnic Preparatory School, Brooklyn, N. Y., and spent four years at the Connecticut Agricultural College, receiving the degree of B.S. in I9I0.

$\mathrm{He}$ is unmarried.

From November, I9I2, to January, I9I3, Bothfeld completed the field work for a working plan of the lands of the New Haven Water Company under the management of the Forest School. A bulletin on this work is to be issued shortly. 


\title{
Leslie A. Bull
}

\author{
Billerica, Mass.
}

Leslie Augustus Bull was born August 24, 1888, in Carlisle, Mass., the son of Sidney A. Bull and Luella Meserve (Cann) Bull. $\mathrm{He}$ has a sister, Leila Sawyer Bull, and a brother, Albert Sidney Bull, Dartmouth '15.

He received the degree of B.A. in I9ro from Dartmouth College, where he was a member of Sigma Alpha Epsilon.

$\mathrm{He}$ is unmarried.

Bull is a partner in the firm of Bull \& Hitchcock, private foresters, of Billerica, Mass.

$\mathrm{He}$ is a member of the Congregational church and in politics is a Republican.

\section{Clifford Cole}

2412 East Twenty-seventh Street, Kansas City, Mo.

Clifford Cole was born October 25, 1889, in Winona, Minn., the son of Harry J. Cole and Abby (Fairchild) Cole. He is of English ancestry.

He received the degree of B.A. in 1910 from Kansas State University, where he was a member of Phi Kappa Psi.

$\mathrm{He}$ is unmarried.

Cole entered the United States Forest Service August IO, I912, as forest assistant on Plumas National Forest, Quincy, Calif., and remained in this position three months. $\mathrm{He}$ is at present engaged in the real estate business in British Columbia.

\section{Alexander W. Dodge \\ 877 Woodbury Road, Pasadena, Calif.}

Alexander William Dodge was born August I, I888, in Valparaiso, Chile, South America, the son of the Rev. William E. Dodge, pastor of Westminster Presbyterian Church in Pasadena, Calif., and of Union Church, Valparaiso, Chile, and Julia Harriett (Trumbull) Dodge. On his father's side his grandfather was Alexander W. Dodge and his grandmother's maiden name was Shafter. Both of these grandparents lived in Michigan. He is the grandson on his mother's side of David Trumbull and Harriett (Fitch) Trumbull of New Haven, Conn. He has two sisters: Anita Trumbull Dodge and Elizabeth Trumbull Dodge. 
He was prepared at the Pasadena High School and in I9ro received the degree of B.S. from Oregon Agricultural College, where he had two years of military drill and was on the non-commissioned staff, color sergeant of the First Regiment.

$\mathrm{He}$ is unmarried.

Dodge is engaged in orange-growing in Pasadena.

$\mathrm{He}$ is a member of the Westminster Presbyterian Church of Pasadena, Calif.

\section{Bruce J. Downey}

Business address, Fosburgh Lumber Company, Vaughn, N.C. Home address, Alexandria, Va.

Bruce Johnson Downey was born December 23, 1888, in Alexandria, Va., the son of John Johnson Downey and Rose E. (Hoblitzell) Downey.

$\mathrm{He}$ graduated at the Virginia Military Institute in 1909. He was a member of the Lambda Sigma chapter of Theta $\mathrm{Nu}$ Epsilon.

$\mathrm{He}$ is unmarried.

Since July I, I912, Downey has been forester for the Fosburgh Lumber Company at Vaughn, N. C.

$\mathrm{He}$ is a member of the Episcopal church.

\section{Carleton W. Eaton}

Business address, Espanola, N. Mex. Home address, Calais, Maine

Carleton Whidden Eaton was born September 2, 1887, in Calais, Maine, the son of Albion Horace Eaton, a lumber and box shook manufacturer, and Annie (MacCullough) Whidden. His grandparents were Charles $\mathrm{H}$. Eaton and Sarah (Keith) Eaton and Charles R. Whidden and Frances (Smith) Whidden. He has two brothers and a sister: Horace Emerson Eaton, a graduate of Colgate Academy; Albion Keith Eaton, a graduate of Phillips Exeter, now attending Bowdoin; and Frances Eaton, a graduate of Burnham School, now attending Smith College.

He took three years at the Calais (Maine) High School and two years at Phillips Academy, Exeter, N. H. He entered the Massachusetts Institute of Technology but only remained one year. In I9Io he received the degree of B.A. at Bowdoin College, where he was a member of Psi Upsilon.

$\mathrm{He}$ is unmarried. 
Since graduation from the Yale Forest School Eaton has served as forest guard and forest assistant. $\mathrm{He}$ is at present in District 3, being located at Espanola, N. Mex.

$\mathrm{He}$ is a Progressive in politics.

\section{Walter M. Geddes \\ Home address, 90 Christopher Street, Montclair, N.J.}

Walter Mackintosh Geddes was born November 13, 1885, in Newark, N. J., the son of Alexander Geddes (deceased) and Susan Isabel (Baker) Geddes. On his father's side he is of Scotch, and on his mother's of English ancestry. His father left the University of Edinburgh when twenty years of age to go to Asia Minor as construction engineer for the MacAndrews \& Forbes Company, manufacturers of licorice, and at the close of our Civil War he came to the United States to open an American agency for this company. He has one sister, Isabel Mary Geddes, M.D. Women's Medical College, and one brother, William Lascelles Geddes. He had two other sisters, now deceased, Susan Baker Geddes, M.D. Cornell 'o2, and Rose Geddes.

He was a student for a year at Stevens Institute of Technology, Hoboken, N. J., and before entering Yale spent five years in Saskatchewan, Canada, and Montana, ranching, and in traveling abroad. In I9II he graduated from the Sheffield Scientific School at Yale, where he was a member of Theta $\mathrm{Xi}$ and of the Yale University Club.

He was married October 13, 1912, in Denver, Colo, to Miss Rebekah Virginia Botsford of Denver, Colo., daughter of Edward Pottle Botsford.

On graduation Geddes became a solicitor for Peters, Byrne \& Company, tree surgeons of Pittsburgh, $\mathrm{Pa}$. He recently resigned this position to go with the MacAndrews \& Forbes Company. He writes: "I have accepted a position with the MacAndrews \& Forbes Company, manufacturers of licorice, and former subsidiary company of the American Tobacco Company. I sail in about three months for Asia Minor, where I shall be assigned to some station in Syria; probably Aleppo, about 100 miles inland from Alexandretta. There I shall endeavor to pick up experience that will fit me for the buying and collection of licorice root for the western branch of the trade. I expect to be located in that part of Asia for at least three years, at the end of which time,- - should I survive the Terrible Turk and other vermin,I shall in all probability return to the States in the employ of the Company here. In a way, I might be called an underground 
forester. The time before I sail will be spent in New York, where Mrs. Geddes and I will attempt the study of Arabic. If we master that tongue, I shall consider it some conquest: the memory I have of the jargon is an impression that resembles the footprints of a herd of chickens on a wet day."

\title{
Norton M. Goodyear
}

Business address, Crossett Lumber Company, Crossett, Ark.

\author{
Home address, Carlisle, Pa.
}

Norton Miller Goodyear was born December 9, I889, in Carlisle, Pa., the son of Jacob M. Goodyear, sheriff of Cumberland County, Pa., and Ellen C. (Miller) Goodyear. He is of German ancestry. He has six brotners: Samuel M., William H., Fiske, Frank J., John J. and Charles A. Goodyear, a graduate of the Damrosch School of Music, New York, and two sisters: Mary Anne Goodyear and Carrie C. Goodyear.

He was prepared at Carlisle $(\mathrm{Pa}$.) High School and received the degree of B.S.F. from Pennsylvania State College in I9II.

$\mathrm{He}$ is unmarried.

From June, I9I2, to February, I9I3, Goodyear was district manager of the Pennsylvania Chestnut Blight Commission with headquarters in Oil City, $\mathrm{Pa}$. $\mathrm{He}$ is now with the Crossett Lumber Company, Crossett, Ark., and expects to follow the lumber business in the future.

$\mathrm{He}$ is a member of the Lutheran church and is a Mason.

\section{Albert W. Hayward}

Business address, Box 84 , Dover, Idaho

Home address, 154 Bridge Avenue, Davenport, Iowa

Albert Wyman Hayward was born August 30, 1888, in Eagle Mills, Ark., the son of Cassius David Hayward, a lumberman, and Emma Louise (Wyman) Hayward. He is the grandson on his father's side of Albert James Hayward and Mary (Frisbie) Hayward of Willsborough, N. Y., and on his mother's side of Daniel Wyman and Anna (Phelps) Wyman. He has a brother, Eugene G. Hayward.

He was prepared at the Davenport (Iowa) High School and in 1910 received the degree of $\mathrm{Ph} . \mathrm{B}$. from Grinnell College.

$\mathrm{He}$ is unmarried.

$\mathrm{He}$ is a member of the Congregational church. At Yale he was elected to Book and Bond Fraternity. 


\author{
Henry J. Hegel \\ Business address, Bogalusa, La. \\ Home address, 148 Sherman Avenue, New Haven, Conn. \\ Box 1845, Yale Station, New Haven, Conn.
}

Henry John Hegel was born February 6, 1889, in New Haven, Conn., the son of Henry John Hegel and Caroline Charlotte (Litterest) Hegel. $\mathrm{He}$ is of German ancestry. He prepared at the Hartford and New Haven High schools and in 1911 graduated from the Sheffield Scientific School at Yale, where he was a member of Alpha Sigma Phi. $\mathrm{He}$ is unmarried.

Hegel has been in the employ of the Great Southern Lumber Company of Bogalusa, La., since June I5, 1912. He has acted at different times as edging inspector, green sorter chain foreman, timber block assistant foreman, clerk in superintendent's office, pond foreman, lumber inspector and checker, and looking up shortages for the shipping department.

$\mathrm{He}$ is an Episcopalian.

\title{
Thomas F. Heineman
}

Business address, United States Forest Service, Hailey, Idaho Home address, Hamburg, Erie County, N. Y.

Thomas Frederick Heineman was born July 22, I886, in McCune, Kans., the son of Fred William Heineman and Martha Ann (Lovelady) Heineman. On his father's side he is of German, and on his mother's of English ancestry. He has a brother, William Heineman.

He received the degree of B.A. from Oberlin College in 1910.

His engagement has been announced.

Heineman entered the United States Forest Service August 20, 1912, as forest assistant with headquarters on Payette National Forest, Emmett, Idaho. In 1913 he was transferred to Sawtooth National Forest, Hailey, Idaho.

$\mathrm{He}$ is a member of the First Congregational Church of Oberlin, Ohio.

\section{Charles F. Hitchcock}

Gilbertville, Mass.

Charles Frederick Hitchcock was born August 30, 1885, in Gilbertville, Mass., the son of Frederick Abner Hitchcock, son of Charles Foster, and 
Clara Mary (Packard) Hitchcock, daughter of Otis Packard. He has a brother, Harold M. Hitchcock, and a sister, Ruth H. Hitchcock.

He was prepared at Williston Seminary and in 1910 graduated from Dartmouth College with the degree of B.S.

$\mathrm{He}$ is unmarried.

Hitchcock is a consulting forester in Gilbertville, Mass.

\section{Jacob S. Kaplan}

Business address, United States Forest Service, Washington, D. C. Home address, 54 East TI8th Street, New York City

Jacob Sidney Kaplan was born January 25, 1891, in New York City, the son of Herman M. Kaplan and Annie (Freedenberg) Kaplan. He has three brothers: Montague L., Manassat and William M. Kaplan; and a sister, Mildred Kaplan.

He received the degree of B.S. in I9Io from the College of the City of New York, where he was a member of Omega Pi Chi.

$\mathrm{He}$ is unmarried.

Upon graduation from the Yale Forest School Kaplan became connected with the Great Southern Lumber Company of Bogalusa, La. In the fall of 1912 he entered the United States Forest Service as forest assistant on Nantahala area, his present position, with headquarters at Andrews, N. C.

\section{John H. Keyes}

Business address, Blue Ridge, Ga.

Home address, 8 Webster Street, Brookline, Mass.

John Humphrey Keyes was born July 9, I890, in Keene, N. H., the son of Herbert Willis Keyes, manager of the Metropolitan Storage Warehouse, Cambridge, Mass., and Harriet Maria (Humphrey) Keyes. His father's parents were from New England. He has a sister, Helen Agnes Keyes, and a brother, Robert Eugene Keyes, B.S. Massachusetts Institute of Technology 'o7.

In IgI he received the degree of B.A. from Amherst College, where he was a member of Phi Kappa Psi and Phi Beta Kappa.

He is unmarried.

On July I, 1912, Keyes became forest assistant in the United States Forest Service with headquarters at Old Fort, N. C. In 
April, 1913, he was transferred to the Georgia area, with headquarters at Blue Ridge, $\mathrm{Ga}$.

$\mathrm{He}$ is a member of the Protestant Episcopal church and of the National Geographic Society.

\section{Raymond M. Killey \\ Business address, Box 105, Traverse City, Mich. \\ Home address, Vivian, W. Va.}

Raymond Marshall Killey was born October 4, 1889, in Pearisburg, Va., the son of Dr. Philip Henry Killey and Eliza Byrnside (Clark) Killey. His father's parents were English and his mother's Virginians.

His early life was spent in West Virginia and in 1908 he received the degree of B.A. from Roanoke College, where he was a member of $\mathrm{Pi}$ Kappa Alpha and Theta $\mathrm{Nu}$ Epsilon. Before entering the Yale Forest School he worked a year for the Peerless Coal Company.

$\mathrm{He}$ is unmarried.

On June 17 , 1912, Killey was appointed assistant superintendent of the Ohio Wood Preserving Company of Orrville, Ohio. $\mathrm{He}$ is still connected with this firm, but is also interested in a company which is to furnish maple, beech, elm and red oak ties to the Grand Rapids \& Indiana Railroad. These ties will be treated at a plant to be built at Cadillac, Mich.

$\mathrm{He}$ is a member of the Episcopal church.

\section{Levon H. Kooyumjian}

Business address, United States Forest Service, Boise, Idaho Care of Mrs. H. K. Avakian, North Grafton, Mass.

Levon Hampartzum Kooyumjian was born December 25, 1885, in Etchme, Harpoot, Turkey in Asia, the son of Hamparizum B. Kooyumjian, son of Bogos Kooyumjian, and Anzoon (Mandirosian) Kooyumjian.

In 1909 he received the degree of B.A. from Amherst College, where he was a member of Sigma Delta Rho.

$\mathrm{He}$ is unmarried.

Since June 19, 1912, Kooyumjian has been forest guard in the United States Forest Service with headquarters on Boise National Forest, Idaho.

$\mathrm{He}$ is a member of the New Britain (Conn.) Congregational Church. 


\section{Bruno R. Kudlich}

Business address, Munson-Whittaker Company, Fourth Avenue and

Twenty-seventh Street, New York City

Residence, I04 West Eighty-seventh Street, New York City

Bruno Ralph Kudlich was born February 10, 1889, in New York City, the son of Dr. Herman F. Kudlich and Roswitha M. L. Kudlich.

He received the degree of B.A. from Columbia University in 1909.

$\mathrm{He}$ is unmarried.

Since the fall of I9I2 Kudlich has been assistant for the Munson-Whittaker Company, foresters, of New York City.

\section{Murray McMurray \\ Webster City, Iowa}

Murray McMurray was born November 19, I888, in Webster City, Iowa, the son of Leslie A. McMurray, graduated from Andover in 1871 , member of the American Board of Commissioners for Foreign Missions and of the Sons of the American Revolution, and president of Hamilton County State Bank for thirty-eight years, and Jessie (Dunham) McMurray, a graduate of Whipple Academy, Troy, N. Y., in 1874, and a member of the Daughters of the American Revolution. $\mathrm{He}$ is the grandson on his father's side of John G. McMurray and Antoinette (Warner) McMurray, and on his mother's side of T. N. Dunham and Achsol (Cannon) Dunham. He has a sister, Jessie Arnold McMurray, B.A. Grinnell College ' 06 .

He was prepared at Webster City (Iowa) High School and in 1910 received the degree of Ph.B. from Grinnell College.

His engagement has been announced.

Since July 15, 1912, McMurray has been clerk in the Hamilton County State Bank of Webster City, Iowa.

$\mathrm{He}$ is a member of the Congregational church and in politics is an Independent, but inclined towards the Republican party. At Yale he was elected to Book and Bond.

\section{Daniel H. Moon, Jr.}

Care Mrs. C. A. Weyerhaeuser, Little Falls, Minn.

Daniel H. Moon, Jr., was born March 16, I883, in St. Paul, Minn.

He was prepared at Phillips Academy, Andover, Mass., and received the degree of Ph.B. at Yale in 1910. He was captain of the Freshman 
Crew, on the Freshman Football Team, on the winning I9II Crew, and a member of Delta Phi, University Club, Corinthian Yacht Club and the City Government Club.

He was married March 8, 1912, in Hamilton, Bermuda, to Mary G. La Tourette.

Moon has sent in the mailing address given above but has failed to state what his present business is.

\section{Willis Munro}

Business address, United States Bureau of Entomology, Providence, R. I. 6I Erie County Bank Building, Buffalo, N. Y.

Willis Munro was born December 3, 1873 , in Boston, Mass., the son of Josiah Greene Munro and Sarah Keen Healey (Dall) Munro. On his father's side he is of Scotch and Welsh ancestry, being the grandson of Peter Greene Munro and Sarah Mumford (Willis) Munro and on his mother's side of Scotch and English descent, the grandson of the Rev. Charles Henry Appleton Dall and Caroline Wells (Healey) Dall. He has a brother, Charles Dall Munro.

He received the degrees of B.A. and LL.B. from Harvard in 1896 and 1899, respectively. For the next five years he was engaged in the practice of law. Owing to ill health, at the end of that time he was forced to give up all work for three years.

He was married October $3 \mathbf{I}$, 1907, in New York City, to Miss Marion Beach Bogardus of Brooklyn, N. Y., daughter of Leonard Bogardus and Julia Keith (Beach) Bogardus.

On July I, I912, Munro became field assistant to the state forester of Connecticut. $\mathrm{He}$ is at present assistant in the United States Bureau of Entomology, Providence, R. I., working on the subject of gypsy moth control.

$\mathrm{He}$ is a member of the Unitarian church. From January I, 1902, to August 15, 1903, he was deputy assistant district attorney of New York County, N. Y. He served in the Massachusetts Naval Brigade, Fourth Division, from January, 1892, to April, 1896, and later held the positions of seaman, quartermaster, gunner's mate, boatswain's mate, chief boatswain's mate and ensign. He also served in the New York National Guard and in Squadron A Cavalry, Troop 3, and was a private three years, beginning in 1902. 


\section{Robert J. Noyes}

Business address, United States Forest Service, Marion, N. C. Home address, Georgetown, Mass.

Robert Jackman Noyes was born December 6, I888, in Georgetown, Mass., the son of Joseph L. Noyes (died April 7, I9I3) and Melvina (Sanborn) Noyes. He has one brother, Joseph E. Noyes, and two sisters: Marjorie S. Noyes, B.A. Mount Holyoke '06, and Ruth E. Noyes.

He was prepared at the Perley Free School, Georgetown, Mass., and at one time attended the University of Maine. In I9II he graduated from the Sheffield Scientific School at Yale, where he was a member of Alpha Tau Omega.

He is unmarried.

Noyes is stationed on the Mt. Mitchell Reservation with headquarters at Marion, N. C. He entered the United States Forest Service on July I, I9I2, and until December I, I912, when he received his present appointment, was forest assistant with headquarters at Gorham, N. H.

\section{J. Wilbur O’Byrne}

Business address, United States Forest Service, Albuquerque, N. Mex. Home address, Oxford, Ohio

Joseph Wilbur O'Byrne was born June 19, I884, in Springfield, Ind., the son of William C. O'Byrne, a farmer, and Ella (McCord) O'Byrne. His father's parents were both born in Ireland and came to America when young, while his mother's father was of Scotch-Irish ancestry, his people having resided in this country for many generations. His maternal grandmother was of Pennsylvania Dutch stock. He has two brothers and two sisters: W. Clarke O'Byrne, E. Esther O'Byrne, a graduate of the normal course at Miami University in 1907, Frank M. O'Byrne, B.A. Miami, and Ernest B. O'Byrne.

He was graduated from high school in 1902 and then entered Miami. He remained about two years and then worked in Cincinnati four years, returning to Miami in 1908 and receiving the degree of B.A. in 1910.

$\mathrm{He}$ is unmarried.

O'Byrne has been in District 3 since entering the United States Forest Service in August, I912. He was forest assistant on Coconino National Forest until recently, when he was transferred 
to Zuni and Manzano forests, with headquarters in Albuquerque, N. Mex. He has been engaged in timber sales work. $\mathrm{He}$ is a member of the Methodist Episcopal church.

\section{William J. Paeth \\ Naperville, III.}

William John Paeth was born July 7, I887, in Naperville, Ill., the son of Carl August Paeth and Sarah Josephine (Weible) Paeth, both deceased. His father was a graduate of Northwestern College and Union Biblical Institute, Naperville, Ill., and at the time of his death was professor of theology in the German department of the Chicago Theological Seminary, Chicago, IIl. He is of German ancestry. He has one brother, Carl August Paeth, who has studied at Northwestern College Academy and Culvers Military Academy.

He was prepared at Northwestern College Academy, Naperville, Ill, and spent two years at the University of Illinois. He also traveled two years before entering Yale. He graduated from the Sheffield Scientific School at Yale in I9r.

$\mathrm{He}$ is unmarried.

Paeth was offered a permanent position as forest assistant in March, I913, under the condition that it be accepted immediately. This was impossible, and the appointment was declined. $\mathrm{He}$ plans to enter private business in Chicago.

$\mathrm{He}$ is a member of the Congregational church.

\section{William B. Rice}

Business address, United States Forest Service, Ogden, Utah

Home address, 803 Mechanic Street, Emporia, Kans.

William Benjamin Rice was born May 21, I888, in Berlin Heights, Ohio, the son of John Hale Julian Rice, a graduate of Oberlin (Ohio) Seminary and Berea (Ky.) College, minister of the First Congregational Church, Emporia, Kans., and Martha (Farrington) Rice. On his father's side he is of English and French ancestry, his grandparents having been born in Virginia and Ohio, and his mother's side of English and Irish ancestry. He has a sister, Amy Rogers Rice.

He was prepared at Oberlin Academy and in I9Io received the degree of B.A. from the College of Emporia. $\mathrm{He}$ is a member of Sigma Xi.

He was married January 29, 1913, in Dodger City, Kans., to Miss Gladys Opal Jones of Dodger City, daughter of Daniel H. Jones. 
Since graduating from the Yale Forest School Rice has been forest assistant in the United States Forest Service. He is located at present in Ogden, Utah.

$\mathrm{He}$ is a member of the Congregational church and in politics is a Progressive Republican.

\section{Leroy M. Richardson}

Business address, Care of Continental Paper Bag Company, Rumford, Maine

Home address, 7 Ravenscroft Road, Winchester, Mass.

Leroy Mowry Richardson was born October I, I886, in Arlington, Mass., the son of Arthur Howard Richardson and Frances Marion (Campbell) Richardson. He has a brother, Lawrence E. Richardson.

$\mathrm{He}$ received the degree of B.A. from Dartmouth College in 1909 and was employed in the Old Colony Trust Company for a year before entering the Yale Forest School.

$\mathrm{He}$ is unmarried.

Since July 6, 1912, Richardson has been clerk in the shipping department of the Continental Paper Bag Company of Rumford, Maine. He was lately employed in the United States Forest Service on Deerlodge National Forest with Supervisor Stockdale on winter reconnaissance.

$\mathrm{He}$ is a member of the Unitarian church. At Yale he was elected to Book and Bond.

\section{Samuel E. Robison \\ Business address, Mechanicsburg, Ohio Home address, 73 Elm Street, London, Ohio}

Samuel Edward Robison was born August 16, 1888, in London, Ohio, the son of Edward John Robison, M.A. Ohio Wesleyan, a druggist, deceased, and Sarah K. Robison. He is of Scotch-Irish ancestry. A sister, Mrs. W. B. Sisson, spent one year at Hollins Institute and one at Ohio Wesleyan, and a brother, Richard H. Robison, studied at Pennsylvania State College two years.

He attended Ohio State University for a time and received the degree of B.S. at Ohio Wesleyan University in I9ro.

$\mathrm{He}$ is unmarried. 
Robison entered the Forest Service immediately upon graduation and was first assigned to Whitman National Forest with headquarters at Sumpter, Ore. In January, I9I3, he was transferred to the district office. He is now engaged in the retail lumber business as a partner in the Sisson-Robison Lumber Company at Mechanicsburg, Ohio.

$\mathrm{He}$ is a member of the Methodist Episcopal church. $\mathrm{He}$ is a Republican and a Mason.

\section{Karl Schmitt}

Business address, Andrews, N. C.

Home address, I8I St. Marks Avenue, Brooklyn, N. Y.

Karl Schmitt was born March 28, 1887, in New York City, the son of William Schmitt and Margaret (Zaisser) Schmitt. He is of German ancestry on his father's side and of German Swiss on his mother's. He has three brothers and a half brother: August, John and William Schmitt, and Max Waldan.

He received the degree of B.S. at the College of the City of New York in February, 1909. Before entering the forest school he was engaged in tree surgery for two summers.

$\mathrm{He}$ is unmarried.

On graduation from the Yale Forest School Schmitt entered the United States Forest Service, being located at Erwin, Tenn. He has recently been transferred to Andrews, N. C., as forest assistant in the Nantahala area, examining land acquired through the Weeks Law.

$\mathrm{He}$ is a Democrat in politics. He is a member of the New York Athletic Club.

\section{Will J. Sproat}

Business address, United States Forest Service, Bend, Ore.

Home address, 1054 Cass Avenue, Grand Rapids, Mich.

Will Jay Sproat was born January 16, I887, in Grand Rapids, Mich., the son of J. C. Sproat.

He received the degree of B.S. from Michigan Agricultural College in I9II. Before entering the Forest School he spent two and a half months on Gunnison National Forest, Colo, and for the same length of time was stationed on Crater National Forest, Ore.

$\mathrm{He}$ is unmarried. 
Upon entering the Service Sproat was appointed a field examiner in the United States Forest Service, being located on the Whitman National Forest, Sumpter, Ore. He now holds the position of forest assistant on Deschutes National Forest, with headquarters at Bend, Ore.

$\mathrm{He}$ is a member of the Congregational church.

\title{
Carl M. Stevens
}

Business address, United States Forest Service, Coeur d'Alene, Idaho Home address, Auburn, Maine

Carl Mantle Stevens was born October 16, I888, in Portland, Maine, the son of T. J. Stevens and Hattie M. Stevens. $\mathrm{He}$ is of English ancestry. A brother, Neil Everett Stevens, received the degree of B.A. at Bates in 1908, M.A. at Yale in 1909 and Ph.D. in I9II.

He received the degree of B.A. at Bates College in I9Io.

$\mathrm{He}$ is unmarried.

Since graduation Stevens has been located in District $\mathbf{I}$. His first appointment was as a forest assistant on the Coeur d'Alene National Forest, Coeur d'Alene, Idaho. In April, I9r3, he was transferred to reconnaissance work.

\section{Clarence E. Taylor}

\author{
R. F. D. 2, Granger, Ind.
}

Clarence Egbert Taylor was born November II, I886, in Scott County, Kans., the son of James Arthur Taylor and Melissa Helen (Rupe) Taylor. His paternal grandparents were Egbert and Elizabeth Taylor. Egbert Taylor was born in what is now Cleveland, Ohio, in 1809 , the first white child born in that township. His ancestors were English and Scotch and his wife's were Scotch-Irish, all coming to this country previous to the Revolutionary War. Melissa Helen (Rupe) Taylor's father was born in 1831 in Indiana of German-Huguenot ancestors, who had settled in North Carolina before the Revolution, her great-great-grandfather dying in that war. Her mother was of Pennsylvania Dutch descent. He has two brothers and a sister: Delbert Jacob Taylor, Purdue University, Glenn Arthur Taylor, and Susan Mae Taylor.

He was prepared at the South Bend (Ind.) High School and received the degree of B.A. at Wabash College in I9Io. He was apprenticed to learn the carpenter's trade.

$\mathrm{He}$ is unmarried. 
In August, 1912, Taylor entered the United States Forest Service as forest assistant with headquarters at Quincy, Calif. From January until June, 1913, he was employed by the Pennsylvania Chestnut Blight Commission. He then reentered the Service, at present being stationed at Pine Mountain, Ga.

\section{Roscoe B. Weaver \\ Business address, 91 $3^{1 / 2}$ Florida Avenue, Tampa, Fla. Home address, Colfax, Iowa}

Roscoe Blaine Weaver was born October 9, I880, in Colfax, Iowa, the son of Jacob Forester Weaver (deceased), who served in the Civil War as first lieutenant of the 5th Iowa Infantry and Cavalry, and was postmaster of Colfax for two years, and Adella Victoria (West) Weaver, daughter of Joseph Taylor West and Susanna Seward (Hahn) West. He has one sister, Di Etta Weaver.

He was prepared at Colfax High School and received the degree of B.S. at Simpson College, Indianola, Iowa, in I905. He was a member of Alpha Tau Omega. He then taught school and coached the Capital High School Football Team, Des Moines, Iowa, for four months. In 1906 he went to the Philippine Islands as a third lieutenant in the constabulary, served three years and a half, rising to the rank of first lieutenant. Before entering the Yale Forest School he took a year's graduate work at Simpson College.

$\mathrm{He}$ is unmarried.

Since July, 1912, Weaver has been with the Aripeka Saw Mills, Tampa, Fla. His work consists chiefly in estimating the company's timber and checking up the saw mills and turpentine users on the company's land.

$\mathrm{He}$ is a Republican. He is a member of the Methodist Episcopal church, is a Mason, and while at Yale was a member of the Yale Masonic Club, Acacia Fraternity.

\section{Edward J. Yeomans \\ Business address, Halstead, Kans.}

Edward John Yeomans was born November II, 1887, in Halstead, Kans., the son of Charles H. Yeomans and Mary L. (Razee) Yeomans. $\mathrm{He}$ is of English and French ancestry. He has three sisters and a brother: Blanch H. (Yeomans) McBurney; Chauncy Austin Yeomans, 
B.A. College of Emporia; Irene L. (Yeomans) Eidson, and Grace M. Yeomans.

He received the degree of B.A. at the College of Emporia in 1910.

His engagement has been announced.

After graduation Yeomans took a position with the Pacific Portland Cement Company of San Francisco, Calif. In March, I9I3, he accepted a permanent appointment with the United States Forest Service, and was assigned to winter reconnaissance on the Pend Oreille National Forest at Sandpoint, Idaho.

$\mathrm{He}$ is a Progressive Republican. He is a member of the Presbyterian church and of Modern Woodmen of America.

\section{Non Graduates}

\section{Samuel E. Bower}

Business address, United States Forest Service, Salt Lake City, Utah Home address, 1328 West Front Street, Berwick, $\mathrm{Pa}$.

Orangeville, $\mathrm{Pa}$.

Samuel Edward Bower was born November 12, 1886, in Fowlerville, $\mathrm{Pa}$, the son of Hiram F. Bower, son of Samuel Edward Bower, and Ida Elizabeth (Mansteller) Bower, daughter of John and Effie Mansteller. He has six sisters: Mary Bessie, Cletta Blanche, Alvaretta Pearl, Ruth Irene, Esther Louise and Florence Elizabeth Bower.

He was prepared at Bloomsburg State Normal School and Gettysburg Preparatory School and in 1910 received the degree of B.A. at Pennsylvania College.

He was married October 22, I9II, in Orangeville, Pa., to Miss Marguerite Lavona Williams, daughter of Warren W. and Lizzie Williams.

Bower is a forest assistant on the Wasatch National Forest with headquarters in Salt Lake City, Utah.

$\mathrm{He}$ is a member of the Progressive party. $\mathrm{He}$ is a member of the Lutheran church.

\section{Charles F. Evans}

Business address, United States Forest Service, St. Anthony, Idaho Home address, Muscoda, Wis.

Charles Floyd Evans was born February 26, 1885, in Basswood, Wis., the son of William T. Evans and Dora (Booker) Evans. 
He received the degree of B.A. at the University of Wisconsin in 1909. During the year 1909-10 he was principal of the Walworth (Wis.) High

School. He attended the Yale Forest School during I9ro and 191 I.

$\mathrm{He}$ is unmarried.

After leaving the Forest School Evans entered the Forest Service and was appointed forest assistant on the Boise National Forest. In January, 1913, he was transferred to the Palisade Forest with headquarters at St. Anthony.

\section{Herman de Fremery}

Business address, American Museum of Natural History, Seventy-seventh Street and Central Park West, New York City

Home address, Woodstock, N. Y.

Columbia University Club, 18 Gramercy Park, New York City

Herman de Fremery was born December 26, 1880, in Oakland, Calif.

He was prepared at the Lyçée Descartes, Tours, France, University of Paris, and Columbia University, New York City.

$\mathrm{He}$ is unmarried.

After leaving the Yale Forest School de Fremery was employed by the Appleton \& Sewall Company, of Old Town, Maine, on timber estimating, mapping and working plans. On October 21, 1912, he entered upon his present position, assistant to the curator of the department of woods and forests at the American Museum of Natural History, New York City.

$\mathrm{He}$ is a Socialist. He is a member of the Columbia University Club and the Liberal Club of New York City.

\section{Raymond F. Gardner}

Business address, Care Trexler Lumber Company, Kearny, N. J.

Residence, 'I72 Grand Street, Jersey City, N. J.

Chester, N.J.

Raymond Foster Gardner was born February 10, 1889, in Appleton, Wis., the son of Edward Payson Gardner, son of Noah Gardner, and Marietta Amanda (Hall) Gardner, daughter of Myron S. Hall. He has three sisters and a brother: Mary L. Gardner; Edward Hall Gardner, B.A. Amherst '05; Katherine Gardner, and Marian W. Gardner, B.A. Smith. 
He was prepared at Blair Academy, Blairstown, N. J., and received the degree of B.A. at Amherst in 1910.

$\mathrm{He}$ is unmarried.

Gardner left the Yale Forest School at the beginning of the spring term of Junior year and has since been with the Trexler Lumber Company, dealers in yellow pine and fir. This company handles fifty million feet a year from their Newark yard.

$\mathrm{He}$ is a Progressive. He is a member of the Presbyterian church. At present he is living in Whetten House, a social settlement in Jersey City.

\section{Conrad Lambert}

74 South Portland Avenue, Brooklyn, N. Y.

Conrad Lambert was born May 8, I885, in Germany. $\mathrm{He}$ received the degree of B.S. from the Brooklyn Polytechnic Institute in 1910 and attended the Yale Forest School during the summer and fall terms of I9I0-II.

\section{Davis W. Lusk, Jr.}

Home address, 48 Berkeley Avenue, Newark, N. J.

Davis Winans Lusk, Jr., was born October 28, I888, in Newark, N. J., the son of Davis W. Lusk, superintendent of the Newark Presbytery and president of the Board of Trustees of the Newark Presbyterian Hospital, and Martha Louise (Winans) Lusk. He is of Scotch ancestry. He has two sisters, Mary Edith Lusk, a graduate of Wheaton Seminary, and Mildred I. Lusk, a graduate of the Newark Normal School.

He was prepared at Bordentown Military Institute, graduating in 1906 , and received the degree of B.A. at Lafayette in Igro. He was a member of Chi Phi.

He is unmarried.

For a few months after graduation Lusk was employed as a field assistant at the Connecticut State Agricultural Experiment Station, New Haven. He then worked for State Forester Hirst of New Hampshire and completed his work in March. He is now connected with the Laurentide Paper Company of Grand Mere, Canada.

$\mathrm{He}$ is a member of the Forest Hill Presbyterian Church, Newark, and is a Republican. 


\section{James E. McNeal}

Business address, Care State Forestry Department, Harrisburg, Pa. Home address, 235 East New Street, Lancaster, Pa.

James Earle McNeal was born October 19, 1887, in Lancaster, Pa., the son of Andrew Carey Flinn McNeal and Margaret Blanche (Hepting) McNeal. His grandparents were Henry Brady McNeal and Emaline Rebecca (Schaeffer) McNeal and Charles A. Hepting and Julia Anna (Long) Hepting. He has a sister, Hilda McNeal.

He was prepared at the public schools of Lancaster, $\mathrm{Pa}$., and received the degree of Bachelor of Forestry at the Pennsylvania State Forest Academy in 1907 .

He is unmarried.

On September I, I907, McNeal entered the employ of the State Forestry Department of Pennsylvania and has since been engaged in the same work except for the time spent at the Yale Forest School in I9IO-II. He has also been a collaborator in the United States Forest Service in the department of products.

He has published reports and bulletins of the Pennsylvania Department of Forestry.

\section{Jason K. Moyer \\ İo Centre Street, Tamaqua, $\mathrm{Pa}$.}

Jason Kline Moyer was born July 20, I885, in Millheim, $\mathrm{Pa}$., the son of Joseph Klose Moyer, a lumberman and postmaster, and Mary Elizabeth Moyer. He is of German ancestry. He has two brothers and six sisters: John Nevin Moyer, Franklin and Marshall; Hiram Bruce Moyer; Eva Moyer; Florence Moyer; Rebecca Moyer, Allentown College for Women; Elizabeth Muyer, Bloomsburg (Pa.) Normal School; Miriam Ruth Moyer, and Sarah Moyer, Bloomsburg (Pa.) Normal School.

He received the degree of $\mathrm{Ph.B}$. at Franklin and Marshall College in 1908. The two years succeeding he taught mathematics and coached the athletic teams at Massanutten School, Woodstock, W. Va. He was a member of Phi Kappa Psi at Franklin and Marshall.

He is unmarried.

After leaving the Yale Forest School Moyer spent an exceptionally interesting summer camping in the mountains of eastern Kentucky and doing forestry work with a forester from State College, one from Biltmore and two from the University of 
Maine. They were employed by Munson-Whitaker Company, foresters, New York City, who were doing a large piece of work for the International Harvester Company. He is now head salesman and assistant buyer for the Moyer Brothers, flour, grain and mill feed merchants.

$\mathrm{He}$ is Independent in politics. He is a member of the Reformed church and an Elk.

\title{
William E. Prindle \\ Business address, Care Eyster \& Son, Halltown, W. Va. Box 624, New Haven, Conn.
}

William Edwin Prindle was born December 5, 1888, in New Haven, Conn., the son of Lucius Henry Prindle, a real estate dealer, and Frances Elizabeth (Harrison) Prindle. His grandfather, Francis E. Harrison, received his B.A. at Yale in 1849. He has one brother, Harrison Prindle, Yale 'o3 S.

He was prepared at the New Haven High School and at the Stadt Gymnasium, Dresden, Germany, and received the degree of $\mathrm{Ph} . \mathrm{B}$. at Yale in 1911 .

$\mathrm{He}$ is unmarried.

Since leaving the Forest School Prindle has been employed as a bond salesman for the American Real Estate Company and with Eyster \& Son, boxboard manufacturers of Halltown, W. Va.

$\mathrm{He}$ is a member of the Protestant Episcopal church.

\author{
Keller E. Rockey \\ Business address, III2 Morris Building, Philadelphia, Pa. \\ Home address, Stone Harbor, N. J.
}

Keller Emrich Rockey was born September 27, 1887, in Columbia City, Ind., the son of Charles H. Rockey, a clergyman, son of Henry Rockey, and Florence I. (Emrich) Rockey, daughter of Captain George P. Emrich. His brothers are Ordean Rockey, Charles H. Rockey, Jr., Walter W. Rockey and John Edward Perry Rockey.

He was prepared at Mercersburg Academy and in I909 received the degree of B.S. at Pennsylvania College, Gettysburg, $\mathrm{Pa}$. $\mathrm{He}$ was a member of Sigma Chi and Theta $\mathrm{Nu}$ Epsilon. Before entering the Forest School he worked in the Forest Service and for the Baltimore \& Ohio Railroad Company.

$\mathrm{He}$ is unmarried. 
Since September 27, I9II, Rockey has been in the employ of the Pennsylvania Chestnut Blight Commission, having charge of the demonstration work.

$\mathrm{He}$ is a Bull Moose.

\section{Franklin L. Wheeler \\ Shelton, Conn.}

Franklin Lyron Wheeler attended the Yale Forest School in I9IO-II.

\section{Howard W. Wills}

Business address, Chicago Telephone Company, Chicago, Ill. Residence, 6rog Kimbark Avenue, Chicago, III. 59 Prospect Street, Bridgeport, Conn.

Howard Wakeman Wills was born August 27, 1889, in Bridgeport, Conn., the son of William Edward Wills and Antoinette (Platt) Wills. $\mathrm{He}$ is of English ancestry. He has a brother, Robert Henry Wills.

He was prepared at the Bridgeport (Conn.) Grammar and High schools and spent one year at Carleton College, Northfield, Minn., before entering the Sheffield Scientific School at Yale. He received the degree of $\mathrm{Ph} . \mathrm{B}$. in $19 \mathrm{II}$ and was a member of Alpha Sigma Phi.

$\mathrm{He}$ is unmarried.

From September, 191 I, to January, 1912, Wills was employed by the Illinois Central Railroad. The next four months he was in real estate work and in May, 1912, he became assistant manager of the traffic department of the Chicago Telephone Company.

$\mathrm{He}$ is a member of the Congregational church and of the Wanderers Athletic Club of Chicago.

\section{Raymond W. Wilson}

64 White Street, Springfield, Mass.

Raymond Walden Wilson was born September 24, 1886, in Willimantic, Conn. He received the degree of B.S. from Dartmouth College in 1910 and attended the Yale Forest School during the summer and fall terms of I9IO-II. 
STATISTICS 



\section{ST A T ISTICAL S UMMARIES}

\section{SUMMARY OF OCCUPATIONS.}

The following tabulation of the occupations of 300 graduates, including both those holding the degree of M.F. and those holding certificates, and eighty-six non-graduates, was compiled by a professor in the Forest School, before information concerning all of the non-graduates had been received:

\begin{tabular}{|c|c|c|c|}
\hline \multirow{2}{*}{\multicolumn{2}{|c|}{ Fnonged in U S Forest Service }} & Graduates & Non Graduates \\
\hline & & I39 & $2 \mathrm{I}$ \\
\hline " & "State Forest Work .................... & 18 & 5 \\
\hline “ & " City Forest Work ................. & 4 & 2 \\
\hline “ & "Forest Work for other Governments .. & 14 & I \\
\hline “ & "Private Forest Work ................. & 22 & 4 \\
\hline " & 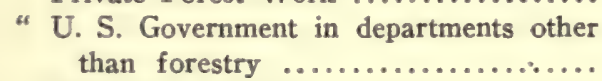 & 7 & 4 \\
\hline “ & "Educational Work ................. & 32 & 4 \\
\hline " & « Lumbering $\ldots . . . \ldots \ldots \ldots \ldots \ldots \ldots$ & 24 & 3 \\
\hline . $c$ & " other occupations $. . . \ldots \ldots \ldots \ldots \ldots . . .$. & 35 & 23 \\
\hline \multirow{2}{*}{\multicolumn{2}{|c|}{ Occupations not reported $\ldots \ldots \ldots \ldots \ldots \ldots \ldots \ldots \ldots \ldots$}} & 5 & 19 \\
\hline & & 300 & $\overline{86}$ \\
\hline
\end{tabular}

A somewhat more detailed study of the distribution by occupations follows:

\begin{tabular}{|c|c|c|c|}
\hline Engaged in U.S. Forest Service & Graduates & Non Graduates & Total \\
\hline 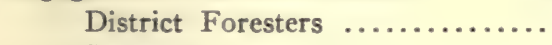 & . $\quad 18$ & 4 & 22 \\
\hline Supervisors $\ldots \ldots \ldots \ldots \ldots \ldots \ldots$ & 22 & 5 & 27 \\
\hline Deputies $\ldots \ldots \ldots \ldots \ldots \ldots \ldots$. & 14 & I & 15 \\
\hline Assistants...$\ldots \ldots \ldots \ldots \ldots \ldots$ & 78 & 9 & 87 \\
\hline Examiners $. . . \ldots \ldots \ldots \ldots \ldots . .$. & 3 & I & 4 \\
\hline Employed ................... & 4 & I & 5 \\
\hline Total in U. S. Forest Service & 139 & $2 \mathrm{II}$ & 160 \\
\hline
\end{tabular}

It is thus seen that of the entire number of men who have attended the Forest School, about 42 per cent are still employed by the Forest Service.

Of the men not now engaged with the Forest Service a total of eighty-six men were formerly employed by the Service. Of these the present occupations are as follows: 
Graduates Non Graduates Total

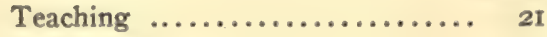

State work ................. Io

Private forestry ............. 8

Connected with lumbering ....... II

In other U. S. departments ..... 6

In other.occupations ........... 24

Total

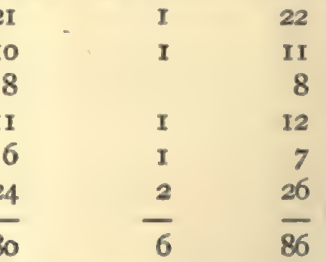

It is thus seen that two-thirds of the men who have left the Forest Service have continued in the profession of forestry and more than half have left to undertake important work in State forestry, teaching, or kindred lines.

\begin{tabular}{|c|c|c|c|}
\hline Engaged in State Forest Work & Graduates & Non Graduates & Total \\
\hline 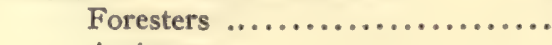 & 6 & 3 & 9 \\
\hline 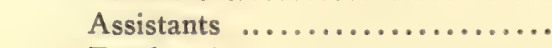 & 8 & 2 & Io \\
\hline Employed $\ldots \ldots \ldots \ldots \ldots \ldots \ldots \ldots$ & 4 & & 4 \\
\hline Total in State work .. & 18 & 5 & 23 \\
\hline
\end{tabular}

The following states employ Yale alumni as State Foresters: Vermont, New Hampshire, Maine, Connecticut, Maryland, Kentucky, North Carolina and Kansas. The following additional states employ Yale men as assistants: New York, Pennsylvania, New Jersey and Minnesota. In Massachusetts the forestry association has two Yale graduates in its employ.

\begin{tabular}{|c|c|c|c|}
\hline Engaged in City Work & Graduates & Non Graduates & Total \\
\hline Foresters $\ldots \ldots \ldots \ldots \ldots \ldots \ldots$ & 2 & 2 & 4 \\
\hline Employed $. . . \ldots \ldots \ldots \ldots \ldots . . . . .$. & 2 & & 2 \\
\hline Totai in City work .......... & 4 & 2 & 6 \\
\hline
\end{tabular}

The City foresters of Brooklyn, Baltimore, Pittsburgh, and New Britain, Connecticut, are Yale men.

Engaged in work of other Governments Graduates Non Graduates Total

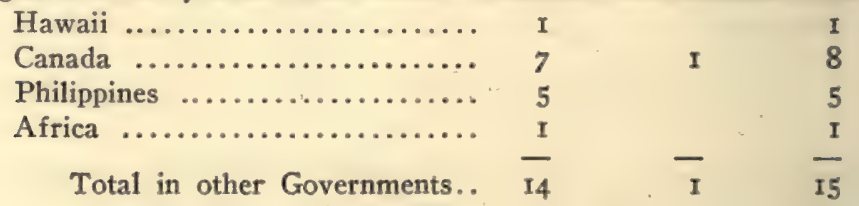

Yale graduates have organized the forestry work in the Province of Quebec and are carrying a large share of the work of organization in the Dominion of Canada and the Province of British Columbia. In 
the Philippines a Yale Forester is Chief of the Service under immediate direction of Captain Ahern. The work in Hawaii was organized by a Yale man. In South Africa two Yale graduates have had much to do with the inauguration of educational and administrative work.

\begin{tabular}{|c|c|c|c|}
\hline Engaged in other departments of U.S. & Graduates & Non Graduates & Total \\
\hline Indian Office $\ldots \ldots \ldots \ldots \ldots \ldots$ & 4 & & 4 \\
\hline Entomology $\ldots . . . \ldots \ldots \ldots \ldots$ & 2 & I & 3 \\
\hline 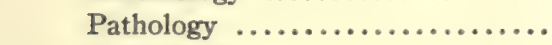 & I & I & 2 \\
\hline Agriculture ................ & & $\mathbf{I}$ & $\mathbf{I}$ \\
\hline 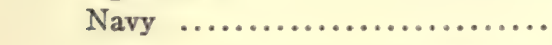 & & $\mathbf{I}$ & $\mathbf{I}$ \\
\hline Total in other departments & $\overline{7}$ & 4 & II \\
\hline
\end{tabular}

The forestry work of the Indian Office has been organized by a graduate of the Forest School.

\begin{tabular}{|c|c|c|c|}
\hline Engaged in educational work & Graduates & Non Graduates & Total \\
\hline Chiefs $\ldots . \ldots \ldots \ldots \ldots \ldots \ldots$ & . $\quad 13$ & I & I4 \\
\hline Assistants $\ldots \ldots \ldots \ldots \ldots \ldots \ldots$ & 19 & 3 & 22 \\
\hline Total educational work ....... & 32 & 4 & \\
\hline
\end{tabular}

The following forest schools are in charge of graduates of the Yale Forest School: Harvard Forest School, University of Washington, Michigan Agricultural College, New York State College of Forestry at Syracuse, University of Nebraska, Washington Agricultural College, New Hampshire Agricultural College, State College of Pennsylvania, University of Maine, University of Minnesota, Massachusetts Agricultural College, University of New Brunswick, and the forest school in South Africa.

In addition the following forest schools have Yale men on their faculty: Cornell University, Yale Forest School, University of Missouri, Oregon Agricultural College, University of Toronto; Ranger School, Philippine Forest Service; and additional men at Harvard, Minnesota, Syracuse, Cornell, University of Washington, Michigan Agricultural College, and the University of Missouri.

Yale Forest School graduates and former students are employed in other occupations as follows:

\section{Lumbering}

With Fire Protective Associations-Secretary ............. 2 . 2

Independent lumbermen ......... 2

Employed by lumber operators ... $\quad 9 \quad 9 \quad 2 \quad$ II

Employed by Timber Land Brokers I $\quad$ I 2


Lumber Manufacturing

Graduates Non Graduates Total

With Associations, Secretary ..... I

Independent manufacturers ...... 3

Associated with Lumber companies

Retail Lumber Dealers

Total in Lumbering

$\begin{array}{lll}\text { I } & \text { I } \\ 3 & & 3 \\ 3 & & 3 \\ 3 & & 3 \\ 24 & 3 & 27\end{array}$

\section{Private Forestry}

Land owners ................. I

Consulting Foresters ........... II

Eucalyptus Company ............. I

Associated with Shade Tree Firms, but doing forestry work .......

Employed by Estates ............

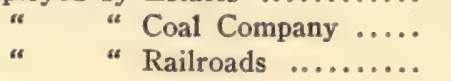

Total in private forestry .... $\overline{22}$

\begin{tabular}{rrr}
4 & & 4 \\
2 & & 2 \\
1 & & 1 \\
2 & I & 3 \\
\hline 22 & 4 & 26
\end{tabular}

\section{Other occupations}

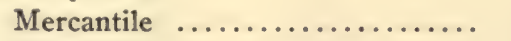

Horticulture ..................

Agriculture ..................

Engineering......$\ldots \ldots \ldots \ldots$

Teaching $. . . \ldots \ldots \ldots \ldots \ldots \ldots . . .$.

Finance $. . . \ldots \ldots \ldots \ldots \ldots \ldots, 3$

Law ...................... 2

Ministry $\ldots \ldots \ldots \ldots \ldots \ldots \ldots$ I

Insurance $\ldots \ldots \ldots \ldots \ldots \ldots \ldots$ I

Medicine ................... I

Real Estate ................. I

Student...$\ldots \ldots \ldots \ldots \ldots \ldots$. I

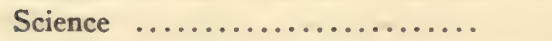

Total in other occupations ... $\overline{35}$

\begin{tabular}{rr} 
IO & I5 \\
I & I0 \\
2 & 9 \\
3 & 6 \\
3 & 4 \\
& 3 \\
& 2 \\
I & 2 \\
& I \\
& I \\
I & 2 \\
I & 2 \\
I & I \\
\hline I & \\
\hline
\end{tabular}

\section{VITAL STATISTICS.}

In the following table are given the number reported married and the number of sons and daughters born to these men for each of the classes. This table includes the 300 graduates, both those holding the degree of M.F. and those holding certificates, and the 102 non-graduates recorded in this volume. In this table the asterisk signifies decease as elsewhere in this record. When the sex of a child is unreported the number is given in parenthesis in the "boys" column. 


\begin{tabular}{|c|c|c|c|c|c|c|c|}
\hline \multirow[b]{2}{*}{ Class } & & \multirow[b]{2}{*}{ Graduates } & \multirow{2}{*}{$\begin{array}{c}\text { Non } \\
\text { Graduates }\end{array}$} & \multirow[b]{2}{*}{ Total } & \multirow[b]{2}{*}{ Married } & \multicolumn{2}{|c|}{ Children } \\
\hline & & & & & & Boys & Girls \\
\hline 1902 & ............. & 9 & & 9 & 5 & (I) $5 * \mathrm{I}$ & \\
\hline 1903 & $\ldots \ldots \ldots \ldots \ldots$ & 17 & 5 & 22 & 15 & I I & $6 *_{1}$ \\
\hline 1904 & ............. & 31 & 5 & 36 & 25 & $15 * 2$ & $17 * 3$ \\
\hline 1905 & ............. & 29 & 9 & 38 & 23 & I $3 * 2$ & 8 \\
\hline I906 & ............. & 17 & 17 & 34 & 19 & 5 & 12 \\
\hline 1907 & ............. & 28 & 9 & 37 & 18 & $6 * I$ & 7 \\
\hline 1908 & ............. & 29 & II & 40 & 16 & 2 & 6 \\
\hline 1909 & .............. & 30 & 7 & 37 & 13 & 3 & \\
\hline I910 & n........... & 33 & 8 & $4 \mathrm{r}$ & 18 & $\mathbf{I}$ & $\begin{array}{llll} & & & \\
\end{array}$ \\
\hline I9II & 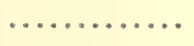 & 43 & I8 & $6 r$ & I4 & & $*_{\mathrm{I}}$ \\
\hline I9I2 & $\ldots \ldots \ldots \ldots$ & 34 & 13 & 47 & 6 & & \\
\hline & & 300 & 102 & 402 & 172 & (I) $6 I * 6$ & $64 * 5$ \\
\hline
\end{tabular}

Of 402 graduates and non-graduates 172 are reported married and to them have been born a total of 137 children, of whom 125 are living. 


\section{ROLL OF THE CLASSES}

In the following roll the permanent address of each man has been used whenever it has been given in the biographical account. Degrees received in addition to Master of Forestry at Yale have been noted after each man's name. The names and addresses of the Class Secretaries of the several classes are printed in italics.

\section{CLASS OF 1902}

Graduates holding Degree of M.F.

Prof. Alfred Akerman, B.A. University of Georgia '98, Athens, Ga.

Charles S. Chapman, B.Agr. Storrs Agricultural College '98, 7r9 Yeon Building, Portland, Ore.

Alfred K. Chittenden, Ph.B. Yale 'oo, Engineering Experiment Station, Urbana, Ill.

George E. Clement, B.A. Harvard ' 0 , 275 Warren Street, Boston, Mass. C. Temple Emmet, M.E. Stevens Institute of Technology '9I, Stony Brook, Long Island, N. Y.

William C. Hodge, Jr., B.A. Yale '99, Forest Service, San Francisco, Calif. Ralph S. Hosmer, B.A.S. Harvard '94, Box 207, Honolulu, Hawaii.

Roy L. Marston, B.A. Bowdoin '99, Skowhegan, Maine.

George H. Myers, B.A. Yale '98, 1509, 38 West Thirty-second Street, New York City.

Graduates holding Degree of M.F. Class of 1902 ...... 9.

\section{CLASS OF 1903}

Graduates holding Degree of M.F.

John B. Anderson, Ph.B. Union ' 96 , Black Mountain, N. C.

Edward A. Braniff, Oklahoma City, Okla.

Prof. George L. Clothier, B.S. Kansas State Agricultural College ' 92 and M.S. '99, State College of Washington, Pullman, Wash.

Albert W. Cooper, B.A. Harvard 'or, 4 Akron Street, Boston, Mass.

Prof. Richard T. Fisher, B.A. Harvard '98, Harvard University, Cambridge, Mass.

*Wesley J. Gardner, B.A. Harvard 'o0. Died 1906.

Prof. Austin F. Hawes, B.A. Tufts College 'or, Experiment Station, Burlington, Vt.

Wallace I. Hutchinson, B.A. Acadia University 'or, Forest Service, Washington, $\mathrm{D}$. C.

Elers Koch, B.S. Montana State College 'or, Forest Service, Missoula, Mont. 
Francis G. Miller, Ph.B. State University of Iowa 'oo, B.S.A. Iowa State College of Agriculture and Mechanic Arts 'OI, Wenatchee, Wash.

Ellie J. S. Moore, B.S. Montana State College 'or, Route 2, Bozeman, Mont.

J. Girvin Peters, B.A. Johns Hopkins 'oo, Forest Service, Washington, D. C.

Prof. Samuel N. Spring, B.A. Yale '98, New York State College of Agriculture, Cornell University, Ithaca, $N . Y$.

William D. Sterrett, B.A. George Washington 'oo and Harvard 'or, Pierce Mill Road, Washington, D. C.

Henry G. Stevens, Ph.B. Yale '02, 6r5 Stevens Building, Detroit, Mich.

Harry D. Tiemann, M.E. Stevens Institute of Technology '97, Forest Products Laboratory, Madison, Wis.

Theodore S. Woolsey, Jr., B.A. Yale 'or, 250 Church Street, New Haven, Conn.

Graduates holding Degree of M.F. Class of 1903 ..... I7

\section{Non Graduates}

Carl G. Crawford, B.S. Ohio Wesleyan University '98, 40I West Main Street, Louisville, Ky.

Samuel B. Detwiler, Bala, Pa.

George Griswold, Lyme, Conn.

Frank C. Hinckley, 26 Central Street, Bangor, Maine.

Paymaster Felix R. Holt, Navy Yard, Norfolk, Va.

\section{CLASS OF 1904}

\section{Graduates holding Degree of M.F.}

John Appleton, B.A. Bowdoin '02, Bangor, Maine.

Robert W. Ayres, Ph.B. Yale 'o3, Forest Service, San Francisco, Calif.

Prof. Hugh P. Baker, B.S. Michigan Agricultural College 'oI, Econ.D.

University of Munich 'Io, New York State College of Forestry, Syracuse, N. Y.

William H. vonBayer, B.A. Cornell '04, Indian Office, Washington,.D. C.

Fred W. Besley, B.A. Maryland Agricultural College '92, Johns Hopkins University, Baltimore, Md.

John H. Bridges, B.S. University of Florida 'o2, Drawer 1607, Tacoma, Wash.

Horatio J. Brown, B.A. Union 'or, 4I4 Lewis Building, Portland, Ore.

Prof. Edward E. Carter, B.A. Bowdoin '02, Petersham, Mass.

Prof. Herman H. Chapman, B.Sc. University of Minnesota '96 and B.Agr. '99, 360 Prospect Street, New Haven, Conn.

Horace W. Chittenden, Ph.B. Yale 'o3, Marine National Bank Building, Buffalo, N. Y.

Harold B. Eastman, B.S. Bowdoin '02, 494 Congress Street, Portland, Maine. 
Stuart J. Flintham, B.A. Cornell '04, III North Normandie, Los Angeles, Calif.

Harold D. Foster, B.A. Williams '02, Forest Service, Medford, Ore.

William B. Greeley, B.L. University of California 'or, Forest Service, Washington, D. C.

Walter B. Hadley, B.S. Pacific College 'or, Redlands, Calif.

Prof. Ralph C. Hawley, B.A. Amherst 'oI, 360 Prospect Street, New Haven, Conn.

Paul D. Kelleter, B.A. Washington University '02, Deadwood, S. Dak.

Charles A. Lyford, F.E. Cornell '04, 520-524 Vancouver Block, Vancouver, B. C., Canada.

Wilbur R. Mattoon, B.A. Wesleyan '99, Forest Service, Washington, D. C.

Hamilton G. Merrill, B.A. Amherst 'o0 and M.A. '05, Forest Service, Santa Barbara, Calif.

Allan B. Patterson, Ph.B. Dartmouth '98, Hot Springs, Tulare County, Calif.

Allan R. Powers, M.D., B.S. University of California 'oI, M.D. Cooper Medical College '12, III Ellis Street, San Francisco, Calif.

Paul G. Redington, B.A. Dartmouth 'oo, Northfork, Madera County, Calif. Avery T. Searle, B.A. Pomona College ' 96 , Brownsville, Texas.

Clinton G. Smith, B.Agr. Storrs Agricultural College '98, Logan, Utah.

Thomas J. Taylor, B.A. University of Chicago '95.

Blaine S. Viles, B.A. Bowdoin 'o3, Augusta, Maine.

William G. Weigle, Forest Service, Washington, D. C.

Robert B. Wilson, B.A. Yale 'or, Medford, Ore.

Graduates holding Degree of M.F. Class of 1904 ..... 29

\section{Graduates holding Certificates}

William H. Kobbé, Shale, Calif.

Manasseh Smith, Jr., 252 Woodfords Street, Portland, Maine.

\section{Non Graduates}

Frank P. Hamilton, B.A. Colby '02, LL.B. Denver University '08, 300 Law Exchange Building, Jacksonville, Fla.

Wilbur F. Henderson, Box I45, Manchester, N. H.

Yukichi Hokodachi.

Richard P. Imes, Custer, S. Dak.

*Louis C. Miller, B.S. Oklahoma Agricultural and Mechanical College 'or,

Died I9Io.

\section{CLASS OF 1905}

Graduates holding Degree of M.F.

Prof. J. Fred Baker, B.S. Michigan Agricultural College '02 and M.For. 'I1, East Lansing, Mich.

John E. Barton, B.A. University of Michigan '02, State Forester, Frankfort, $\mathrm{Ky}$. 
Anton T. Boisen, B.A. Indiana University '97, Ames, Iowa.

Harold R. Bristol, F.E. Cornell '04, Box I86, Plattsburgh, N. Y.

Clarence J. Buck, B.A. Williams 'o3, 405 Beck Building, Portland, Ore.

Philip T. Harris, B.A. Bowdoin '03, Forest Service, Tacoma, Wash.

Janero Lagdameo, B.A. Ateneo de Manila '96, Bureau of Forestry, Manila, P. I.

Jacob J. Levison, B.A. College of the City of New York '02, Prospect Park, Brooklyn, N. Y.

James P. McDonough, B.A. Yale '03, 38 Hallock Street, New Haven, Conn.

William H. Mast, B.Agr. Iowa State College 'oo, Davenport, Iowa.

Clayton D. Mell, B.A. Franklin and Marshall College 'oo, Lebanon, Pa.

Prof. Walter J. Morrill, B.S. University of Maine '99, University of Nebraska, Lincoln, Neb.

Harry C. Neal, B.S. Pennsylvania State College 'o3, Dravosburg, Pa.

John M. Nelson, Jr., B.A. Johns Hopkins 'o3, Pottsville, $\mathrm{Pa}$.

William B. Piper, B.A. Harvard 'o3, East Tawas, Mich.

Merritt B. Pratt, B.S. University of Chicago 'o3, Nevada City, Calif.

Jeremiah Rebmann, B.S. University of Nebraska '98, III4 Marion Street, Columbia, S. C.

Prof. Samuel J. Record, B.A. Wabash College '03 and M.A. '06, 360 Prospect Street, New Haven, Conn.

Arthur C. Ringland, Forest Service, Washington, D. C.

William F. Sherfesee, B.A. College of Charleston 'o3, Bureau of Forestry, Manila, P. I.

Ferdinand A. Silcox, B.S. College of Charleston '03, Forest Service, Missoula, Mont.

Gordon E. Tower, B.S. Michigan Agricultural College 'or, Waldo Hills Orchard Company, Route 5, Salem, Ore.

Lage Wernstedt, M.E. Royal Institute of Technology (Stockholm) '02, Forest Service, Portland, Ore.

Trueman D. Woodbury, Ph.B. Brown 'o3, Forest Service, San Francisco, Calif.

Karl W. Woodward, B.A. Cornell 'o4, Forest Service, Washington, D. C. Theodore C. Zschokke, B.A. Leland Stanford Jr. University 'o3, Palo Alto, Calif.

Graduates holding Degree of M.F. Class of $1905 \ldots \ldots 26$

Graduates holding Certificates

Harry M. Hale, Okanogan, Wash.

John S. Holmes, Chapel Hill, N. C.

Stanton G. Smith, Forest Service, Seattle, Wash.

\section{Non Graduates}

James M. Fetherolf, B.A. Muhlenberg College 'or, Forest Service, Ogden, Utah.

David G. Kinney, Forest Service, San Diego, Calif. 
Harold D. Langille, 683 Wasco Street, Portland, Ore.

Chester A. Mathewson, 354 New York Avenue, Brooklyn, N. Y.

Ernest A. Sanders, M.A. Ohio State University 'o3, Westerville, Ohio.

Herbert O. Stabler, Forest Service, 501 Beck Building, Portland, Ore.

Gardiner Watkins, B.A. Princeton '03, 317 Broadway, New York City.

Arnot W. Whetstone, M.A. Ohio State University '03, Van Buren, Ohio.

Edmund J. Zavitz, B.A. McMaster University (Toronto) '03, Ontario Agricultural College, Guelph, Ont., Canada.

\section{CLASS OF 1906}

Graduates holding Degree of M.F.

J. Howard Allison, Ph.B. Yale '05, College of Forestry, University Farm, St. Paul, Minn.

Fred E. Ames, B.A. Harvard '03, Forest Service, 50r Beck Building, Portland, Ore.

Martin L. Erickson, Flandreau, S. Dak.

Dennis C. A. Galarneau, B.A. Tufts '04, ro Bayle Street, Montreal, Que., Canada.

John D. Guthrie, Ph.B. Union '02, Forest Service, Springerville, Ariz.

James A. Howarth, Jr., LL.B. Yale ' 96 , Care of Indian Agent, Cloquet, Minn.

Frederick W. H. Jacombe, B.A. University of Toronto ' 96 and M.A. '98, Forestry Branch, Department of the Interior, Ottawa, Ont., Canada.

Sydney L. Moore, B.A. Princeton, '04, R. R. Sizer \& Company, I5 William Street, New York City.

Andrew E. Oman, B.S. Kansas State Agricultural College 'oo, Weiser, Idaho.

Arthur D. Read, B.A. College of Emporia '03, Forest Service, Washington, D. C.

Prof. Arthur B. Recknagel, B.A. Yale '04, Department of Forestry, Cornell University, Ithaca, N. Y.

Alexander H. D. Ross, B.A. Queen's University '88 and M.A. '89, University of Toronto, Toronto, Ont., Canada.

Robert Y. Stuart, B.A. Dickinson 'o3 and M.A. '06, Forest Service, Washington, D. C.

Horace F. Studley, B.A. Harvard '05, Rockland, Mass.

W. Hoyt Weber, B.A. Wesleyan '03, I5I Courtland Avenue, Stamford, Conn.

George A. Wilmot, University of the Cape of Good Hope '95, Katwijk, Holland, ' 96 , Office of the Jokai Retreat, Union of South Africa.

Graduates holding Degree of M.F. Class of 1906 ..... I6

\section{Graduate holding Certificate}

Rudo L. Fromme, B.S. Ohio State University '05, Olympia, Wash. 


\section{Non Graduates}

Ford D. Bacon, Bucknell '04, Harveyville, $\mathrm{Pa}$.

*Jacob F. Bitner, Franklin and Marshall College '04. Died I9r2.

Edward G. Cheyney, B.A. Cornell 'oo, University Farm, St. Paul, Minn.

Galen S. Cleland, Wells, York County, Maine.

Walter O. Filley, Connecticut Agricultural Experiment Station, New Haven, Conn.

*Gay E. Hills, B.A. Dartmouth 'o4.

Died ror I.

Elmer R. Hodson, B.S. Iowa State College '98 and M.S. 'oo, Forest Service, Ogden, Utah.

J. Osborne Hopwood, B.S. University of Pennsylvania '04, M.S. Yale 'o7, Primos, Delaware County, $\mathrm{Pa}$.

Thomas P. Ivy, B.A. Harvard '8I, Conway Center, N. H.

John E. Keach, B.A. Yale 'oo, Forest Service, Washington, D. C.

Albert H. Pierson, B.A. Princeton '99, Forest Service, Washington, D. C. W. Kerr Rainsford, Ridgefield, Conn.

Jerome H. Ramskill, Delta, Colo.

Charles A. Scott, B.S.A. Kansas State Agricultural College 'or, 31 I North Eighteenth Street, Manhattan, Kans.

Alpheus O. Waha, Forest Service, Albuquerque, N. Mex.

Prof. John P. Wentling, Franklin and Marshall College 'o2, University Farm, St. Paul, Minn.

Leslie L. White, B.S. Pennsylvania College, Vernal, Utah.

\section{CLASS OF 1907}

Graduates holding Degree of M.F.

William B. Barrows, B.A. Columbia '05, Forest Service, Washington, D. C.

Avila Bédard, B.A. Laval University '05, Parliament Buildings, Quebec, Que., Canada.

Prof. John Bentley, Jr., B.S. Wesleyan '04, New York State College of Agriculture, Ithaca, N. Y.

Ovid M. Butler, B.A. Butler College 'o2, Forest Service, Ogden, Utah.

Prof. Philip T. Coolidge, B.A. Harvard '05, New York State Ranger School, Wanakena, N. Y.

Lincoln Crowell, B.S. University of Maine 'o6, Office of Indian Affairs, Neopit, Wis.

Stephen M. Crowell, B.Agr. Connecticut Agricultural College 'o2 and B.S. '05, Middletown, Conn.

Samuel T. Dana, B.A. Bowdoin '04, Forest Service, Washington, D. C.

Raymond Davis, B.A. Bowdoin '05, Yakima Hotel, North Yakima, Wash.

Nils B. Eckbo, Stenkjar Skogskole (Norway) '04, Forest Service, Ogden, Utah.

Prof. John H. Foster, B.S. Norwich University '03, Durham, N. H. 
Bartle T. Harvey, B.S. University of Maine '05, 46 Maine Street, Orono,. Maine.

Charles S. Judd, B.A. Yale '05, Forest Service, Portland, Ore.

Francis B. Kellogg, B.S. University of California '05, 98 El Camino Real, Berkeley, Calif.

Kingsley R. MacGuffey, B.A. Yale '05, Parkdale, Ore.

Clyde S. Martin, B.S. DePauw University '05, 304 West Third Street, Aberdeen, Wash.

David T. Mason, B.S. Rutgers '05 and M.S. '08, Forest Service, Missoula, Mont.

Louis S. Murphy, B.S. Tufts 'or, 4 Thurston Street, Winter Hill Station, Boston, Mass.

Gustave C. Piché, 64 St. Cyrille Street, Quebec, Que., Canada.

Colin C. Robertson, Forest Department, Pretoria, South Africa.

David N. Rogers, B.S. University of Maine 'o6, Quincy, Calif.

Robert Rosenbluth, Conservation Commission, Albany, N. Y.

Alfred Senn, Swiss French College '8I, Care Board of Park Commissioners, Milwaukee, Wis.

William C. Shepard, F.E. Cornell '07, R. F. D. 59, Berlin, Conn.

Charles P. Wilber, B.A. Rutgers '05 and M.A. '08, Forest Commission, State House, Trenton, N. J.

Hugo Winkenwerder, B.S. University of Wisconsin '02, 405 North Washington Street, Watertown, Wis.

*Edward S. Woodruff, B.A. Yale ' 99.

Died 1909.

Graduates holding Degree of M.F. Class of 1907 ..... 27

\section{Graduate holding Certificate}

William Winter, I003 Majestic Building, Indianapolis, Ind.

\section{Non Graduates}

J. Franklin Bruins, B.A. Beloit Colfege '05, Box 249, Pocatello, Idaho.

Harrison DeW. Burrall, Forest Service, Albuquerque, N. Mex.

Charles H. Flory, B.S. Ohio State University '05, Forest Service, Portland, Ore.

James L. Grimes, B.S. Princeton '05, Knoxville, Pittsburgh, Pa.

Prof. Burt P. Kirkland, B.A. Cornell '05, University of Washington, University Station, Seattle, Wash.

Robinson M. MacMurray, Montana State Land Exchange, Helena, Mont.

F. Van Thompson, State Hospital Commission, Albany, N. Y.

Charles M. Walker, B.S. Massachusetts Agricultural College '99, IIo East Twenty-third Street, New York City.

E. LeVerne Wood, Barceloneta, Porto Rico. 


\section{CLASS OF 1908}

Graduates holding Degree of M.F.

Raymond W. Allen, B.S. Rutgers ' 06 , Forest Service, Cody, Wyo.

Prof. Nelson C. Brown, B.A. Yale ' 06 , New York State College of Forestry, Syracuse, N. Y.

Frederick H. Brundage, Ph.B. Yale 'o7, Forest Service, Albany, Ore.

Prof. Elias T. Clark, Ph.B. Yale '07, University of Washington, University Station, Seattle, Wash.

Ernest D. Clark, Ph.B. Yale '07, R. F. D. I, Litchfield, Conn.

Robert E. Clark, Ph.B. Yale '07, Forest Service, Washington, D. C.

Arthur M. Cook, B.A. Harvard '06, 135 Academy Street, Laconia, N. H.

Prof. John A. Ferguson, B.A. Hamilton ' 96 and M.A. 'o3, Pennsylvania State College, State College, $\mathrm{Pa}$.

H. Earl French, B.S. University of Iowa '06, Halsey, Neb.

Jesse R. Hall, B.S. University of California '05, Yreka, Calif.

R. Clifford Hall, B.S. Northwestern University 'o6, Forest Service, Washington, D. C.

William C. Latané, B.S. Virginia Polytechnic Institute '05, Libby, Mont.

Charles A. Lewis, B.A. Trinity '93, 3 West Fifty-fourth Street, New York City.

Forman T. McLean, Ph.B. Yale 'o7, Ephraim, Utah.

Harvey R. MacMillan, B.S.A. University of Toronto 'o6, Forest Branch, Victoria, B. C., Canada.

Willis N. Millar, B.S. University of Pennsylvania 'o6, Box 1253, Calgary, Alta., Canada.

Robert B. Miller, B.S. Wabash College ' 96 and M.A. '06, Box 256, Thorntown, Ind.

Barrington Moore, B.A. Yale '06, Forest Service, Washington, D. C.

Thornton T. Munger, B.A. Yale '05, Forest Service, Portland, Ore.

Robert L. Rogers, B.A. Yale '06, Forest Service, Washington, D. C.

Julian E. Rothery, Ph.B. Yale 'o7, Wellesley, Mass.

Edward B. Starr, B.A. Yale 'o7, Cornwall, Conn.

Dillon P. Tierney, B.Sc.F. University of Minnesota '06, State Capitol, St. Paul, Minn.

Wilford B. Willey, B.A. Cornell 'o7, Saint Maries, Idaho.

Hubert C. Williams, Ph.B. Yale 'o6, Lakeville, Conn.

Graduates holding Degree of M.F. Class of 1908

\section{Graduates holding Certificates}

Chester B. Cox, Santa Maria, Calif.

Joseph A. Fitzwater, Sandpoint, Idaho.

Francis M. Patton, 95 Charlotte Street, Asheville, N. C.

Rutledge Parker, Missoula National Forest, Missoula, Mont. 


\section{Non Graduates}

*Burgess Dickinson, Ph.B. Yale 'o7.

Died 1913.

Prof. George E. Gage, M.A. Yale '07 and Ph.D. '09, Amherst, Mass.

Walter W. Gleason, B.S. Allegheny College 'o6, Johnsonburg, Pa.

James E. Martin, B.S. Massachusetts Agricultural College 'o6, Forest

Service, Leadville, Colo.

Wilfred E. Murchie, Ph.B. Yale 'o7, 80 Broad Street, New York City.

Royal F. Nash, B.S. Columbia '08, Grand Rapids, Wis.

Herbert S. Nelson, Ph.B. Yale '05, 758 Savin Avenue, West Haven, Conn. Aretas A. Saunders, Ph.B. Yale 'o7, Forest Service, Chouteau, Mont.

John A. Sweigert, Plattsburg, N. Y.

Dean S. Tiffany, Hop Bottom, Pa.

Ralph B. Wainwright, Ph.B. Yale '07, 63 Curtis Street, New Britain, Conn.

\section{CLASS OF 1909}

Graduates holding Degree of M.F.

F. F. Woods Beckman, Stockholms Hõgre Reallãroverk '05, Finspong, Sweden.

Frederick H. Billard, B.A. Yale ' 96 , Meriden, Conn.

John M. Briscoe, The Colonial, Bangor, Maine.

Georges deS. Canavarro, B.S. University of Minnesota '08, Forest Service, Washington, D. C.

Prof. William D. Clark, B.A. Yale '04, 25 North Prospect Street, Amherst, Mass.

John D. Coffman, Forest Service, Weaverville, Calif.

Arthur W. DuBois, B.A. Cornell 'o7, Hallstead, Pa.

Herman E. Fegley, B.A. Franklin and Marshall College '04, 508 Laurel Street, Pottsville, $\mathrm{Pa}$.

Frederick A. Gaylord, Ph.B. Yale '08, 69 South Cliff Street, Ansonia, Conn.

Belknap C. Goldsmith, B.S. University of California 'o6, Forest Service, Alturas, Calif.

Edgar C. Hirst, B.A. Ohio State University 'o7, Concord, N. H.

Oswald D. Ingall, B.A. Cornell '07, 99 South Fullerton Avenue, Montclair, N. J.

Henry L. Johnson, B.A. Cornell 'o7, 54 Broadway Extension, Boston, Mass.

R. Chapin Jones, B.A. Vanderbilt University '04, 9 Concord Avenue, Cambridge, Mass.

Joseph C. Kircher, B.A. Yale 'o7, Forest Service, Albuquerque, N. Mex. Aldo Leopold, Ph.B. Yale 'o8, Forest Service, Albuquerque, N. Mex.

Everett H. MacDaniels, B.A. Oberlin 'o6, Forest Service, Beck Building, Portland, Ore.

Rufus S. Maddox, B.A. Yale 'o7, Quincy, Calif. 
Prof. Frederick F. Moon, B.A. Amherst 'or, New York State College of Forestry, Syracuse University, Syracuse, N. Y.

William B. Osborne, Jr., B.A. Williams 'o7, Forest Service, Beck Building, Portland, Ore.

Percy J. Paxton, B.A. Williams 'o6, Forest Service, Denver, Colo.

Reuben P. Prichard, B.S. Dartmouth 'o7, New York State College of Forestry, Syracuse University, Syracuse, N. Y.

Abbott B. Silva, Ph.B. Yale '08, Forest Service, Missoula, Mont.

Robert Simmons, B.A. College of City of New York ' 06.

Thomas E. Snyder, B.A. Columbia '07, Bureau of Entomology, Washington, D. C.

Willard Springer, Jr., C.E. Lafayette 'o7, 8ro Washington Street, Wilmington, Del.

Chester H. Wilcox, C.E. Lehigh 'o7, Center Moriches, N. Y.

Addison W. Williamson, Ph.B. Wesleyan '07, Forest Service, Washington, D. C.

Meyer H. Wolff, Ph.B. Yale '08, Forest Service, Newport, Wash.

Graduates holding Degree of M.F. Class of 1909 ..... 29

Graduate holding Certificate

Allen H. Hodgson, IIg Fourth Street, Chico, Calif.

Non Graduates

Oliver E. Baker, B.S. Heidelberg College (Ohio) 'o3 and M.S. '04, M.A. Columbia '05, Department of Agriculture, Washington, D. C.

Hugh G. Calkins, B.S. University of California '06, Forest Service, Albuquerque, N. Mex.

William E. Dunham, Ph.B. Yale '08, Warren, Pa.

H. Julian C. Humphrey, Ph.B. Yale '08.

Richard L. Lovell, Ph.B. Yale '07, Yale Station, New Haven, Conn.

Axel E. T. Moberg.

Ernest C. Wheeler, B.A. Yale 'o7, 6 Arch Street, Norwalk, Conn.

\section{CLASS OF I9I0}

Graduates holding Degree of M.F.

Walter G. Alpaugh, B.S. Tufts '08, Willimantic, Conn.

William G. Baxter, B.S.A. Iowa State College '08, Galva, Iowa.

George A. Bright, 2d, B.S. Dartmouth '08, Forest Service, Portland, Ore.

Donald Bruce, B.A. Yale 'o6, Forest Service, Missoula, Mont.

Charles R. Clark, B.A. University of Wisconsin 'o9, Forest Service, Washington, D. C.

Guy C. Cleveland, B.A. Yale '08, The North Jersey Excelsior Company, Butler, N. J.

Hamilton M. Coan, B.A. Princeton '07, Forest Service, Sumpter, Ore.

George A. Cromie, 14 Compton Street, New Haven, Conn. 
Robert E. Dickson, B.S. Michigan Agricultural College 'o9, East Lansing, Mich.

Richard C. Eggleston, Ph.B. Yale 'o9, Forest Service, Saint Maries, Idaho.

Robie M. Evans, B.A. Dartmouth 'o6, Fryeburg, Maine.

Harold Fay, B.A. Tufts '04, 92 Professor's Row, Tufts College, Mass.

Max H. Foerster, Care Consolidation Coal Company, Jenkins, Ky.

William H. Gallaher, Ph.B. Yale 'og, Santa Barbara, Calif.

Harold P. Gilkey, B.A. Harvard 'o9, Richland, Mich.

James L. Goodwin, B.A. Yale '05, I9I Farmington Avenue, Hartford, Conn.

Lester E. Hitchcock, B.S. Coe College '07, Forest Service, Ogden, Utah.

Crosby A. Hoar, B.A. Dartmouth '08, Meeker, Colo.

Stephen V. Klem, Ph.B. Yale '09, I5 Lake Place, New Haven, Conn.

Julius A. Larsen, B.A. Yale '08, Forest Service, Washington, D. C.

Raymond E. Marsh, B.S. Dartmouth '08, Westport, N. H.

Frank B. Notestein, Ph.B. University of Wooster '08, Forest Service, Denver, Colo.

Mauricio J. Oteyza, B.S. Kansas State Agricultural College 'ro, Los Bãnos, Laguna, P. I.

Dana Parkinson, B.A. Dartmouth '08, Forest Service, Boise, Idaho.

Stuart B. Show, B.A. Leland Stanford Jr. University '08, Sisson, Calif.

William N. Sparhawk, B.A. Yale '08, Forest Service, Ogden, Utah.

Irving G. Stetson, B.A. Harvard '07, 180 Exchange Street, Bangor, Maine.

Albert O. Vorse, B.S. Bucknell '05 and M.S. 'II, Care Peters, Byrne \& Company, Ardmore, $\mathrm{Pa}$.

Robert S. Wallace, B.A. Macalester College '08, Forest Service, Harrison, Ark.

Edgar F. White, B.A. Dartmouth '08, Forest Service, Missoula, Mont.

Walter K. Wildes, B.A. Bowdoin '04, Little Falls, Passaic County, N. J. Graduates holding Degree of M.F. Class of I9I0 ..... 3r

\section{Graduates holding Certificates}

B. Frank Heintzleman, Fayetteville, Pa.

Sedman W. Wynne, Hot Springs, Calif.

\section{Non Graduates}

Edward S. Davey, B.A. Yale 'o8, 67 Hawthorne Avenue, Glen Ridge, N. J. Ernest G. Dudley, B.A. Leland Stanford Jr. University '08, Stanford University, Calif.

Ben Hershey, B.A. Williams '06, 1026 Henry Building, Seattle, Wash.

*Thomas Hooker, B.A. Yale 'o8.

Died Igog.

James L. Leeper, Jr., Ph.B. Yale 'o9, 304 Clinton Avenue, Kingston, N. Y.

Samuel B. Locke, B.S. University of Maine '08, Forest Service, Ogden, Utah.

Glenn W. Traer, Jr., Ph.B. Yale '09, 4363 Oakenwald Avenue, Chicago, Ill. Alvin G. Whitney. 


\section{CLASS OF I9II}

Graduates holding Degree of M.F.

Waldo D. Barlow, B.S. Massachusetts Agricultural College 'o9, Helena, Mont.

Oliver F. Bishop, Ph.B. Yale 'o9, 174 Grand Avenue, New Haven, Conn.

Elwood P. Bushnell, B.S. Michigan Agricultural College 'ro, Bronson, Mich.

Norman C. Case, B.S. Highland College 'o8, Albuquerque, N. Mex.

Bernard A. Chandler, B.S. University of Maine 'og, Vermont Forest Service, Burlington, Vt.

Neal T. Childs, B.A. Yale 'og, Bretton Hall, Broadway and Eighty-sixth Street, New York City.

Walter J. Damtoft, Ph.B. Yale '10, 98 Beechwood Avenue, Bridgeport, Conn.

Howard deForest, B.S. Princeton '95, Care of J. D. deForest, 25 Broad Street, New York City.

Theodore W. Dwight, B.S.F. University of Toronto 'Io, Forestry Branch, Ottawa, Ont., Canada.

John H. Fahrenbach, B.A. Franklin and Marshall College 'o9, Bernville, $\mathrm{Pa}$.

Arthur F. Fischer, C.E. Ohio Northern University '09, Bureau of Forestry, Manila, P. I.

Charles Goodwin, Ph.B. Yale 'ro, ro7o Bushwick Avenue, Brooklyn, N. Y.

Alfred B. Hastings, B.A. Dartmouth '04, Orofino, Idaho.

James O. Hazard, Ph.B. Brown '08, Westerly, R. I.

Jesse W. Hough, B.S. Pomona College 'o8, Claremont, Calif.

Dwight S. Jeffers, B.A. Illinois Wesleyan University ' 66 , Forest Service, Laramie, Wyo.

Fred R. Johnson, B.S. Dickinson '09, 44 North Oak Street, Mt. Carmel, Pa.

Ernest F. Jones, B.A. Haverford 'o7, South China, Maine.

Otto Katz, B.S. College City of New York '09, 30 East I Igth Street, New York City.

Arthur F. Kerr, B.A. University of Oregon 'og, Forest Service, Portland, Ore.

Eugene L. Lindsey, Virginia Military Institute 'o9, Alexandria, Va.

Thomas E. McCullough, B.C.E. Iowa State College 'o9, Forest Service, Flagstaff, Ariz.

Samuel R. MacDonald, Ph.B. Yale '09, R. F. D. I, Wallingford, Conn.

A. Fletcher Marsh, Ph.B. Yale 'Io, I207 East Fifty-third Street, Chicago, III.

Seward H. Marsh, B.A. Berea 'o9, Berea, Ky.

Frederick R. Mason, B.S. Rutgers '05, Bound Brook, N. J.

George Z. Mason, B.S. College City of New York '09, Iro7 Forest Avenue, New York City.

George R. Monell, B.A. College City of New York 'o9, 1598 Lexington Avenue, New York City. 
Albert E. Moss, Connecticut Agricultural College '05, West Cheshire, Conn.

Harold S. Newins, Ph.B. Lafayette 'og, Patchogue, N. Y.

Douglas K. Noyes, B.A. Yale 'o7, Forest Service, Yreka, Calif.

Lawrence B. Pagter, B.A. Yale 'o9, 8 Vernon Street, New Haven, Conn.

Ernest C. Pegg, B.A. Wabash 'o9, Fountain City, Ind.

Edward C. M. Richards, Ph.B. Yale '09, II9 East Seventy-first Street, New York City.

Abraham Rosenmond, B.S. College City of New York '09, 7I Lenox Avenue, New York City.

Harold L. Russell, B.A. Johns Hopkins 'o9, Forest Service, Appalachian Division, Washington, D. C.

John W. Spencer, B.A. College of Emporia 'o9, Emporia, Kans.

Louis R. Stadtmiller, Ph.B. Yale '10, 429 Atlantic Street, Stamford, Conn. J. Warrington Stokes, B.S. Haverford 'og, Holmesburg, Philadelphia, Pa. Myron W. Thompson, B.S. Massachusetts Agricultural College 'o9, Forest Service, Cody, Wyo.

Robert E. Thompson, B.S. Michigan Agricultural College 'ro, Grand Rapids, Mich.

Sidney H. Thompson, B.A. Dartmouth ' 99,47 Summer Street, St. Johnsbury, Vt.

Charles H. Watzek, Ph.B. Yale 'Io, I407 Brady Street, Davenport, Iowa. Graduates holding Degree of M.F. Class of I9II ..... 43

\section{Non Graduates}

Charles E. Beaumont, Ph.B. Yale 'o9, Rocky Hill, Conn.

Roger B. Briggs, Connecticut Agricultural College 'og, Broad Street, Stratford, Conn.

Sydney F. Brown, Ph.B. Yale 'ro, 83 Prospect Street, Reading, Mass.

Philip L. Buttrick, Orange, Conn.

Charles H. Edwards, B.S. Michigan Agricultural College '09, Forest Service, Washington, D. C.

W. Irving Gilson, B.S. Michigan Agricultural College '10, 59 North Main Street, Adrian, Mich.

Richard H. Goode, B.A. Dartmouth '07, 30 Brastow Avenue, Somerville, Mass.

Raymond W. Gowdy, Ph.B. Yale 'ro, Thompsonville, Conn.

James H. Hull, B.A. Yale 'o7, 3I5 South Main Street, Torrington, Conn. John Lautz, Ph.B. Yale 'ro, 384 DeWolfe Place, Hackensack, N. J.

Elmer B. Mason, B.A. Princeton '03, Bureau of Entomology, Washington, D. C.

Harry Olin, B.S. Michigan Agricultural College 'ro, Rush City, Minn.

Earl S. Pierce, Ph.B. Yale 'og, Frankfort, Maine.

Archer E. Roberts, 97 Fern Street, Hartford, Conn.

Kurt Roehrs, Ph.B. Yale 'ro, Roswell, N. Mex.

Robert Stephenson, B.A. Columbia ' 99,22 Bank Street, New York City. 
Frederick W. Toerner, B.A. College City of New York '02, 758 East I6oth Street, New York City.

Richard W. Walker, C.E. Lehigh University '84, Glenmore, Pa.

\section{CLASS OF 1912}

Graduates holding Degree of M.F.

William R. Barbour, Ph.B. Yale 'II, 420 Hyde Avenue, Ridgway, Pa.

Victor A. Beede, B.A. Yale 'ro, 425 Temple Street, New Haven, Conn.

Henry J. Bothfeld, B.S. Connecticut Agricultural College '10, 450 Ovington Avenue, Brooklyn, N. Y.

Leslie A. Bull, B.A. Dartmouth 'ro, Billerica, Mass.

Clifford Cole, B.A. Kansas State University '10, 2412 East Twenty-seventh Street, Kansas City, Mo.

Alexander W. Dodge, B.S. Oregon Agricultural College 'ro, 877 Woodbury Road, Pasadena, Calif.

Bruce J. Downey, Virginia Military Institute 'o9, Fosburgh Lumber Company, Vaughn, N. C.

Carleton W. Eaton, B.A. Bowdoin 'ro, Calais, Maine.

Walter M. Geddes, Ph.B. Yale 'II, go Christopher Street, Montclair, N. J.

Norton M. Goodyear, B.S.F. Pennsylvania State College 'II, Carlisle, Pa.

Albert W. Hayward, Ph.B. Grinnell College '10, 154 Bridge Avenue, Davenport, Iowa.

Henry J. Hegel, Ph.B. Yale 'Ir, Box 1845, Yale Station, New Haven, Conn.

Thomas F. Heineman, B.A. Oberlin 'ro, Hamburg, N. Y.

Charles F. Hitchcock, B.S. Dartmouth 'ro, Gilbertville, Mass.

Jacob S. Kaplan, B.S. College City of New York 'Io, 54 East II8th Street, New York City.

John H. Keyes, B.A. Amherst 'Ir, 8 Webster Street, Brookline, Mass.

Raymond M. Killey, B.A. Roanoke College '08, Vivian, W. Va.

Levon H. Kooyumjian, B.A. Amherst 'og, Care of Mrs. H. K. Avakian, North Grafton, Mass.

Bruno R. Kudlich, B.A. Columbia 'o9, 104 West Eighty-seventh Street, New York City.

Murray McMurray, Ph.B. Grinnell College 'Io, Webster City, Iowa.

Daniel H. Moon, Jr., Ph.B. Yale 'ro, Little Falls, Minn.

Willis Munro, B.A. Harvard '96 and LL.B. '99, 6r Erie County Bank Building, Buffalo, N. Y.

Robert J. Noyes, Ph.B. Yale 'ri, Georgetown, Mass.

J. Wilbur O'Byrne, B.A. Miami 'ro, Oxford, Ohio.

William J. Paeth, Ph.B. Yale 'II, Naperville, Ill.

William B. Rice, B.A. College of Emporia 'IO, Forest Service, Ogden, Utah.

Leroy M. Richardson, B.A. Dartmouth ' 09,7 Ravenscroft Road, Winchester, Mass. 
Samuel E. Robison, B.S. Ohio Wesleyan 'io, Mechanicsburg, Ohio.

Karl Schmitt, B.S. College City of New York '09, 18I St. Mark's Avenue, Brooklyn, N. Y.

Will J. Sproat, B.S. Michigan Agricultural College 'II, 1054 Cass Avenue, Grand Rapids, Mich.

Carl M. Stevens, B.A. Bates 'ro, Auburn, Maine.

Clarence E. Taylor, B.A. Wabash 'ro, R. F. D. 2, Granger, Ind.

Roscoe B. Weaver, B.S. Simpson College '05, Colfax, Iowa.

Edward J. Yeomans, B.A. College of Emporia 'ro, Hallstead, Kans.

Graduates holding Degree of M.F. Class of 1912 .... 34

\section{Non Graduates}

Samuel E. Bower, B.A. Pennsylvania College 'ıo, Orangeville, $\mathrm{Pa}$.

Charles F. Evans, B.A. University of Wisconsin 'o9, Muscoda, Wis.

Herman de Fremery, Columbia University Club, 18 Gramercy Park, New York City.

Raymond F. Gardner, B.A. Amherst 'ro, Chester, N. J.

Conrad Lambert, B.S. Brooklyn Polytechnic Institute 'ro, 74 South Portland Avenue, Brooklyn, N. Y.

Davis W. Lusk, Jr., B.A. Lafayette 'ro, 48 Berkeley Avenue, Newark, N. J.

James E. McNeal, B.F. Pennsylvania State Forest Academy 'o7, 235 East

New Street, Lancaster, $\mathrm{Pa}$.

Jason K. Moyer, Ph.B. Franklin and Marshall College '08, iı Centre Street, Tamaqua, $\mathrm{Pa}$.

William E. Prindle, Ph.B. Yale 'II, Box 624, New Haven, Conn.

Keller E. Rockey, B.S. Pennsylvania College 'o9, III2 Morris Building, Philadelphia, $\mathrm{Pa}$.

Franklin L. Wheeler, Shelton, Conn.

Howard W. Wills, Ph.B. Yale 'II, 59 Prospect Street, Bridgeport, Conn. Raymond W. Wilson, B.S. Dartmouth 'ro, 64 White Street, Springfield, Mass.

Total Graduates holding Degree of M.F. Classes of

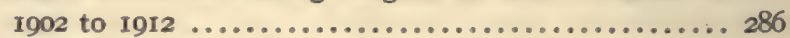

Total Graduates holding Certificates ............. 14

Non Graduates recorded in this volume ........... 102

Total names recorded in this volume $\ldots \ldots \ldots \ldots, 402$ 


\section{INDEX TO BIOGRAPHIES}

Akerman, A., '02 ............ PAGE

Allen, R. W., ${ }^{\circ} 08, \ldots \ldots \ldots \ldots \ldots \ldots \ldots \ldots$ 181

Allison, J. H., 'o6 ............. 122

Alpaugh, W. G., 'ro .............. 239

Ames, F. E., 'o6 ................ 123

Anderson, J. B., 'o3 ............ 46

Appleton, J., ${ }^{\circ} 04 \ldots \ldots \ldots \ldots \ldots 6 . \ldots 6$

Ayres, R. W., '04 .............. 66

Bacon, F. D., ex-'06 ............ 138

Baker, H. P., '04 .............. 67

Baker, J. F., 'o5 ............... 94

Baker, O. E., ex-'og ............. 235

Barbour, W. R., '12 ........... 302

Barlow, W. D., 'I .............. 265

Barrows, W. B., '07 .............. I 49

Barton, J. E., 'o5 ................ 94

Baxter, W. G., 'ro ............... 239

vonBayer, W. H., '04 ........... 69

Beaumont, C. E., ex-'11 ......... 291

Beckman, F. F, W., 'o9 ........... 214

Bédard, A., 'o7 ................ I50

Beede, V. A., 'I2 ............. 303

Bentley, J., 'oy ................. x $_{51}$

Besley, F. W., '04 ............. 70

Billard, F. H., 'og ............. 215

Bitner, J. F., $e x$ ' $06 \ldots \ldots \ldots \ldots \ldots^{2} \ldots \ldots \ldots$

Bishop, O. F., 'rx ............. 265

Boisen, A. T., 'o5 ............... 95

Bothfeld, H. J., '12 ............ 303

Bower, S. E., ex-'r2 ............ 319

Braniff, E. A., '03 ............. 46

Bridges, J. H., '04 .............. 7r

Briggs, R. B., ex-11 ............ 291

Bright, G. A., "10 ............. 240

Briscoe, J. M., 'o9 ............. 215

Bristol, H. R., "05 ............... 96

Brown, H. J., '04 ............... 72

Brown, N. C., $08 \ldots \ldots \ldots \ldots$ I8 8 .

Brown, S. F., ex-'1I ........... 292

Bruce, D., 'xo ..................... 240

Bruins, J. F., ex-'o7 ............ I 76

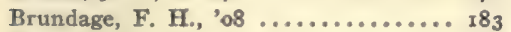

Buck, C. J., '05 ............... 96

Bull, L. A., '12 ................ 304

Burrall, H. DeW., ex'oy .......... 177

Bushnell, E. P., 'xx ............. 266

Butler, O. M., 'o7 .............. I5

Buttrick, P. L., ex-'11 ............ 293

Calkins, H. G., ex-'og .......... 236

Canavarro, G. deS., "og ........... 216

Carter, E. E., '04 .............. 72
Case, N. C., 'II PAGE

Chandler, B. A., 'ı ............ 268

Chapman, C. S., 'o2 ........... $3^{6}$

Chapman, H. H., 'o4 ........... 73

Cheyney, E. G., ex-'06 .......... 139

Childs, N, T., 'II ................ 268

Chittenden, A. K., 'oz .......... 37

Chittenden, H. W., $04 \ldots \ldots \ldots \ldots . . .73$

Clark, C. R., 'so .............. 24r

Clark, E. D., 'o $8 \ldots \ldots \ldots \ldots \ldots \ldots \ldots . . . .184$

Clark, E. T., $08 \ldots \ldots \ldots \ldots \ldots \ldots \ldots$

Clark, R. E., 'o8 ................ r 86

Clark, W. D., 'og ............... 217

Cleland, G. S., ex.'06 ........... r40

Clement, G. E., '02 ............. ${ }_{38}$

Cleveland, G. C., 'ro ........... 242

Clothier, G. L, ${ }^{\circ} 0_{3} \ldots \ldots \ldots \ldots \ldots \ldots . . .47$

Coan, H, M, 'ro ............... 243

Coffman, J. D., 'og ............. 217

Cole, C., 'ı ................. 304

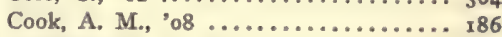

Coolidge, P. T., ${ }^{\prime} 07 \ldots \ldots \ldots \ldots \ldots$

Cooper, A. W., '03 .............. 49

Cox, C. B., cert. 'o8 ........... 203

Crawford, C. G., ex-o3 ........... $66_{3}$

Cromie, G. A., "ro ............. 244

Crowell, L., 'o7 ................. 153

Crowell, S. M., '07 ............. 153

Damtoft, W. J., 'II ............. 269

Dana, S. T., "07 ............... 154

Davey, E. S., ex-'ro ............. 260

Davis, R., 'o7 ................ 155

deForest, $H_{.},{ }^{\text {, }} \mathbf{I}$................ 270

Detwiler, S. B., ex-'o3 .......... 64

Dickinson, B., ex-'08 ........... 206

Dickson, R. E., '10 .............. 244

Dodge, A. W., '12 .............. 304

Downey, B. J., '12 ........... 305

DuBois, A. W., 'og .............. 218

Dudley, E. G., $e x-{ }^{3} 10 \ldots \ldots \ldots \ldots \ldots 261$

Dunham, W. E., ex-og ........... 237

Dwight, $\boldsymbol{T}$. W., 'ix ........... 270

Eastman, H. B., '04 ............... 74

Eaton, C. W., '12 .............. 305

Eckbo, N. B., 'o7 ................ 156

Edwards, C. H., ex-'II ........... 293

Eggleston, R. C., '10 ............ 245

Emmet, C. T., '02 .............. 39

Erickson, M. L., ' $06 \ldots \ldots \ldots \ldots$. . . . 124

Evans, C. F., ex-'12 .............. 319

Evans, R. M., 'so ............ 246 
Fahrenbach, J. $\mathrm{H}, \mathrm{PAGE}$

Fay, H., '10 ................... 246

Fegley, H. E., 'og ............. 219

Ferguson, J. A., $08 \ldots \ldots \ldots \ldots \ldots . . . . .187$

Fetherolf, J. M., ex-'os ........... x16

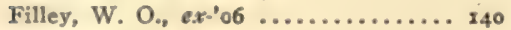

Fischer, A. F., 'x ............. 272

Fisher, R. T., 'o3................ 49

Fitzwater, J. A., cert. '08 ......... 203

Flintham, S. J., $04 \ldots \ldots \ldots \ldots \ldots 75$

Flory, C. H., ex-'oy ........... 178

Foerster, M. H., "ro ............. 247

Foster, H. D., "04 .............. 76

Foster, J. H., 'o7 ............... 157

deFremery, $H_{2,}$ ex-'1z ........... 320

French, H. E., '08 ............... 188

Fromme, R. L., cert. '06 ... . . . . I 37

Gage, G. E., ex-'08 ............ 207

Galarneau, D. C. A., '06 .......... 125

Gallaher, W. H., 'ro ............. 247

Gardner, R. F., ex-'I2 ........... 320

Gardner, W. J., "03 ............. 50

Gaylord, F. A., 'o9 ............. 220

Geddes, W. M., '12 ............. 306

Gilkey, H. P., 'xo ............... 248

Gilson, W. I., $e x-1$ I I ... . . . . . . . . . 294

Gleason, W. W., $e x-08 \ldots \ldots \ldots \ldots . . .207$

Goldsmith, B. C., 'og .............221

Goode, R. H., ex-'xI ............ 295

Goodwin, C., 'xx ............... 272

Goodwin, J. L., 'ro .............. 348

Goodyear, N. M., 'ז2 ........... 307

Gowdy, R. W., ex-'ı1 ............ 296

Greeley, W. B., '04 ............ 77

Grimes, J. L., ex-'07 .......... 178

Griswold, G., ex-03 ........... 65

Guthrie, J. D., "06 ............. 125

Hadley, W. B., '04 ............... 78

Hale, H. M., cert. '05 ........... I I 4

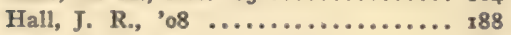

Hall, R. C., 'o8 ................. 189

Hamilton, F. P., ex-'04 ........... 9r

Harris, P. T., $05 \ldots \ldots \ldots \ldots . . . . . . . . .67$

Harvey, B. T., 'o7 ............. 158

Hastings, A. B., 'II ............ 273

Hawes, A. F., 'o3 .............. sx

Hawley, R. C., "04 ............. 79

Hayward, A. W., '12 .......... 307

Hazard, J. O., '11 .............. 274

Hegel, H, J., 'rz . . . . . . . . . . 308

Heineman, T. F., '13 ........... 308

Heintzleman, B. F., cert, 'xo ...... 259

Henderson, W. F., ex+'04 ......... 92

Hershey, B., ex-10 ............. 26r

Hills, G. E., ex-'06 ............. r4t

Hinckley, F. C., $e x \cdot 03 \ldots \ldots \ldots \ldots, 65$

Hirst, E. C., 'og ............... 221
Hitcheock, C TS PAGE

12 $12 \ldots \ldots \ldots \ldots \ldots, 308$

Hitchcock, L. E., 'xo ............. 250

Hoar, C. A., 'so ................ 250

Hodge, W. C., 'o2 .............. 39

Hodgson, A. H., cert. 'o9 .......... 234

Hodson, E. R., ex'o6 ............. I 4 I

Hokodachi, Y., ex-'04 ............. 92

Holmes, J. S., cert. 'o5 ........... I15

Holt, F. R., $6 x-103 \ldots \ldots \ldots \ldots \ldots \ldots 65$

Hooker, T., ex-'10 .............. 262

Hopwood, J. O., ex-'06 ............ 142

Hosmer, R. S., '02 .............. 40

Hough, J. W., '11 ............... 274

Howarth, J. A., '06 ............. 127

Hull, J. H., ex-'I1 . . . . . . . . . . . 296

Humphrey, H. J. C., $e x-' 09 \ldots \ldots \ldots .237$

Hutchinson, W. I., '03 .......... 52

Imes, R. P., ex-'04 .............. 92

Ingall, O. D., 'og ................ 222 Ivy, T. P., ex:'06 ................ I42 Jacombe, F. W. H., '06 .......... 128 Jeffers, D. S., 'xI ............... 275 Johnson, F. R., '11 .............. 275 Johnson, H. L., 'og ............. 223 Jones, E. F., 'xx ............... 276 Jones, R. C., 'og ................. 223 Judd, C. S., 'o7 ................. 859 Kaplan, J. S., '12 .............. 309 Katz, O., '11 ................... 276

Keach, J. E., ex-'06 ............. I 43 Kelleter,.P. D., '04 ............... rg Kellogg, F. B., 'o7 .............. I6z Kerr, A. F., ' 11 ................. 277 Keyes, J. H., '12 ............... 309 Killey, R. M., '12 ............... 310 Kinney, D. G., ex-'05 ............ 117 Kircher, J. C., 'og ................. 224 Kirkland, B. P., exo'07 ............ 179 Klem, S. V., '10 .............. 25I Kobbé, W. H., cert. 'o4 ............. 89 Koch, E., 'o3 ................. 52 Kooyumjian, L. H., '12 ........... 310 Kudlich, B. R., 'r2 ............. 3 II Lagdameo, J., 'o5 ................ 98 Lambert, C., ex-12 ................ 321 Langille, H. D., ex-'05 ............. I 18 Larsen, J. A., '10 ............... 252 Lantané, W. C., 'o8 .............. 189 Lautx, J., ex.'11 ... . . . . . . . . . . . . . 297 Leeper, J. L., ex-'zo ............ 262 Leopold, A., '09 ................... 225 Levison, J. J., 'o5 ............... 98 Lewis, C. A., 08 ................ 190 Lindsey, E. L., ' $x 1 \ldots \ldots \ldots \ldots \ldots .277$ Locke, S. B., ex-'ro .............. 263 Lovell, R. L., ex-'og ............. 238 Lusk, D. W., $e x-12 \ldots \ldots \ldots \ldots \ldots . . .32 \mathrm{I}$ 
Lyford, C. A., '04 ............. 80

McCullough, T. E., 'II ........... 278

MacDaniels, E. H., 'og ............ 226

MacDonald, S. R., "II .............. 279

McDonough, J. P., 'os ............ 100

MacGuffey, K. R., ${ }^{\circ}$ o $\ldots . . \ldots \ldots \ldots . .163$

McLean, F. T., '08 .............. rgo

MacMillan, H. R., '08 .......... r r

McMurray, M., '12 ............. 311

MacMurray, R. M., ex-'o7 ......... 180

McNeal, J. E., ex-'r2 ............. 322

Maddox, R. S., 'og ............... 226

Marsh, A. F., '11 ............. 279

Marsh, R. E., '10 ................. as"

Marsh, S. H., '11 ............. 280

Marston, R. L., '02 .............. 42

Martin, C. S., ${ }^{\prime 07}$................ 164

Martin, J. E., ex-'08 ................208

Mason, D. To, '07 .............. 165

Mason, E. B., ex-1x .............. 297

Mason, F. R., '11 ............... 281

Mason, G. Zo, 'xI .............. 28x

Mast, W. H., '05 ................. 100

Mathewson, C. A., exo'os .......... x10

Mattoon, W. R., '04 .............. 8I

Mell, C. D., '05 ................ 102

Merrill, H. G., 'o4 ............. 82

Millar, W. N., '08 ............. 193

Miller, F, G., 'o3 ............... 53

Miller, L. C., ex-'04 .............. 93

Miller, R. B., '08 ................ 193

Moberg, A. E. T., ex-'09 ............ 238

Monell, G. R., 'xI ............. 282

Moon, D. H., "12 .............. 311

Moon, F. F., '09 .............. 227

Moore, B., 08 .................... ro4

Moore, E. J. S., '03 .............. 54

Moore, S. L., '06 ................ 128

Morrill, W. J., '05 ............... 103

Moss, A. E., '11 ............... 282

Moyer, J. K., ex-'12 ................. 322

Munger, T. T., '\$8 ............. 196

Munro, W., '13 .................. 312

Murchie, W. Ea, ex-'08 ............ 209

Murphy, L. S., 'o7 ................ 166

Myers, G. H., '02 ............... 44

Nash, R. Fo, ex-08 ............... 209

Neal, H. C., 'o5 ................. 104

Nelson, H. S., $e x-' 08 \ldots . \ldots \ldots \ldots . . .2 \times 0$

Nelson, J. M. 'o5 ............... 104

Newins, H. S., '18 ............... 283

Notestein, F. B., 'xo ............. 253

Noyes, D. K., 'II ............... 283

Noyes, R. J., '12 ................ 313

O'Byrne, J. W., 'r2 ............. 3 1 3

Olin, $H_{0,}$ ex ${ }^{\prime} x 1$................ 298

Oman, A. E., 'o6 ................ 139
PAGE

Osborne, W. B., 'og ............. 228

Oteyza, M. J., '10 .............. 254

Paeth, W. J., 'x2 .............. 314

Pagter, L. B., 'xs ................ 284

Parker, R., cert. '08 .............. 205

Parkinson, D., 'ro ................ 254

Patterson, A. B., '04 ............ 8z

Patton, F. M., cert. 'o8 ............ 204

Paxton, P. J., 'og .............. 229

Pegg, E. C., 'rr ................ 284

Peirce, E. S., exo' $1 x$... . . . . . . . . 299

Peters, J. G., 'o3 ................ 54

Piché, G. C., 'o7 ............... I68

Pierson, A. H., ex-'06 .............. I44

Piper, W. B., '05 .............. r 105

Powers, A. R., '04 .............. 83

Pratt, M. B., '05 ................ 106

Prichard, R. P., 'og .............. 229

Prindle, W. E., ex-'12 ............ 323

Rainsford, W. K., $e x-106 \ldots \ldots \ldots \ldots . .144$

Ramskill, J. H., ex-"06 ............. 144

Read, A. D., 'o6 ................. 130

Rebmann, J., 'o5 ................ roy

Recknagel, A. B., 'o6 ............. 13 II

Record, S. J., '05 ............... ro7

Redington, P. G., '04 ........... 84

Rice, W. R., '12 ............... 314

Richards, E. C. M., '1I .......... 285

Richardson, L. M., '12 ........... 315

Ringland, A. C., '05 .............. 109

Roberts, A. E., ext'II ............. 299

Robertson, C. C., 'o7 ............. 169

Robison, S. E., 'r2 ............. 315

Rockey, K. E, ex-'12 ........... 323

Roehrs, K., $e x-{ }^{\prime} 11$................. 299

Rogers, D. N., 'oz ................ 169

Rogers, R. L., '08 ............. 197

Rosenbluth, R., 'o7 .............. 170

Rosenmond, A., 'xx ............... 286

Ross, A. H. D., '06 ............. 133

Rothery, J. E., '08 .............. 197

Russell, H. L., 'x $11 . . \ldots \ldots \ldots \ldots \ldots .286$

Sanders, E. A., ex-'o5 ............ 120

Saunders, A. A., exo'08 ........... 211

Schmitt, K., '12 ............... 316

Scott, C. A., ex-'06 .............. 845

Searle, A. T., '04 ............... 85

Senn, A., 'o7 ................. 178

Shepard, W. C., 'o7 .............. 172

Sherfesee, W. F., "05 ............ 109

Show, S. B., 's0 ................. 355

Silcox, F. A., '05 .............. Ino

Silva, A. B., 'og .............. 230

Simmons, R., $09 \ldots \ldots \ldots \ldots \ldots \ldots . .230$

Smith, C. G., '04 ................ 85

Smith, M., cert. '04 ............. gr

Smith, S. G., cert. 'o5 ............. 115 
Snyder, T. E., 'og ............. 230

Sparhawk, W. N., 'xo ............ 255

Spencer, J. W., 'II ............ 287

Spring, S. N., '03 ............. 56

Springer, W., 'og .............. 232

Sproat, W. J., '1 . ............. 316

Stabler, H. O., $e x-' 05$............ 120

Stadtmiller, L. R., 'II ........... 287

Starr, E. B., '08 ................ $x 98$

Stephenson, R., $c x^{\prime} 11$. . . . . . . . . 300

Sterrett, W. D., '03 ............. 58

Stetson, I. G., ${ }^{\prime}{ }_{10} \ldots \ldots \ldots \ldots \ldots \ldots \ldots .256$

Stevens, C. M., "12 ............. 317

Stevens, H. G., '03 ............... 59

Stokes, J. W., '11 ............... 288

Stuart, R. Y., "06 ... . . . . . . . . . I34

Studley, H. F., 'o6 ............. 135

Sweigert, J. A., es-'08 ........... 212

Taylor, C. E. 'r2 ............... 3x

Taylor, T. J., '04 .............. 87

Thompson, M. W., "' 1 . ........... 288

Thompson, R. E., ' 1 I .............. 289

Thompson, S. H., ' $x \mathbf{1} \ldots \ldots . . . \ldots \ldots .289$

Tiemann, H, D., $03 \ldots \ldots \ldots \ldots . . .59$

Tierney, D. P., '08 ... . . . . . . . . . . . I 199

Tiffany, D. S., $c x-08 \ldots \ldots \ldots \ldots \ldots .213$

Toerner, F. W., ex' 11 .......... 300

Tower, G. E., '05 ............... III

Traer, G. W., ex-'xo ...............264

Van Thompson, F., ex-'0y ......... 180

Viles, B. S., '04 ............. 87

Vorse, A. O., '10 .............. 257

Waha, A. 0.,ex'06 ............. ז 46

Wainwright, R. B., ex-'08 ......... $2 x_{3}$

Walker, C. M, ex-'o ............ r8o

Walker, R. W., $e x 0^{\prime} 11$........... 300
PAGE

Wallace, R. S., 'ro ...............257

Watkins, G., ex-'05 ............. 12I

Watzek, C. H., 'ı1 .............. 290

Weaver, R. B., '12 ............. 318

Weber, W. H., '06 ............... 136

Weigle, W. G., '04 ............. 88

Wentling, J. P., ex'06 ......... 147

Wernstedt, L., '05 ............. 18

Wheeler, E. C., ex.'09 ........... 238

Wheeler, F. L., ex-'12 ............ 324

Whetstone, A. W., ex'05 ......... rax

White, E. F., '10 ............... 258

White, L. L., ex'06 ............... 148

Whitney, A. G., ex'ro ............. 264

Wilber, C. P., 'o7 ................ 872

Wilcox, C. H., '09 .............. 232

Wildes, W. K., '10 ............... 258

Willey, W. B., '08 ............ 201

Williams, H. C. , 0 ............. 202

Williamson, A. W., 'o9 ........... 233

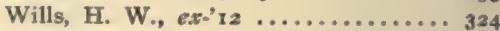

Wilmot, G. A., '06 .............. 136

Wilson, R. B., '04 ............. 89

Wilson, R. W., ex'12 ........... 324

Winkenwerder, H., '07 ............ 174

Winter, W., cert. 'o7 ............. 175

Wolff, M. H., 'o9 ................. 233

Wood, E. LeV., exr-'07 ............ 180

Woodbury, T. D., '05 …........ 112

Woodruff, E. S., 'o7 .............. x74

Woodward, K. W., '05 ........... 113

Woolsey, T. S., '03 .............. 6r

Wynne, S. W., cert. '10 .......... 360

Yeomans, E. J., '12 ............ 318

Zavitz, E. J., ex'o5 ............. I2x

Zschokke, T. C., '05 ............ 113 




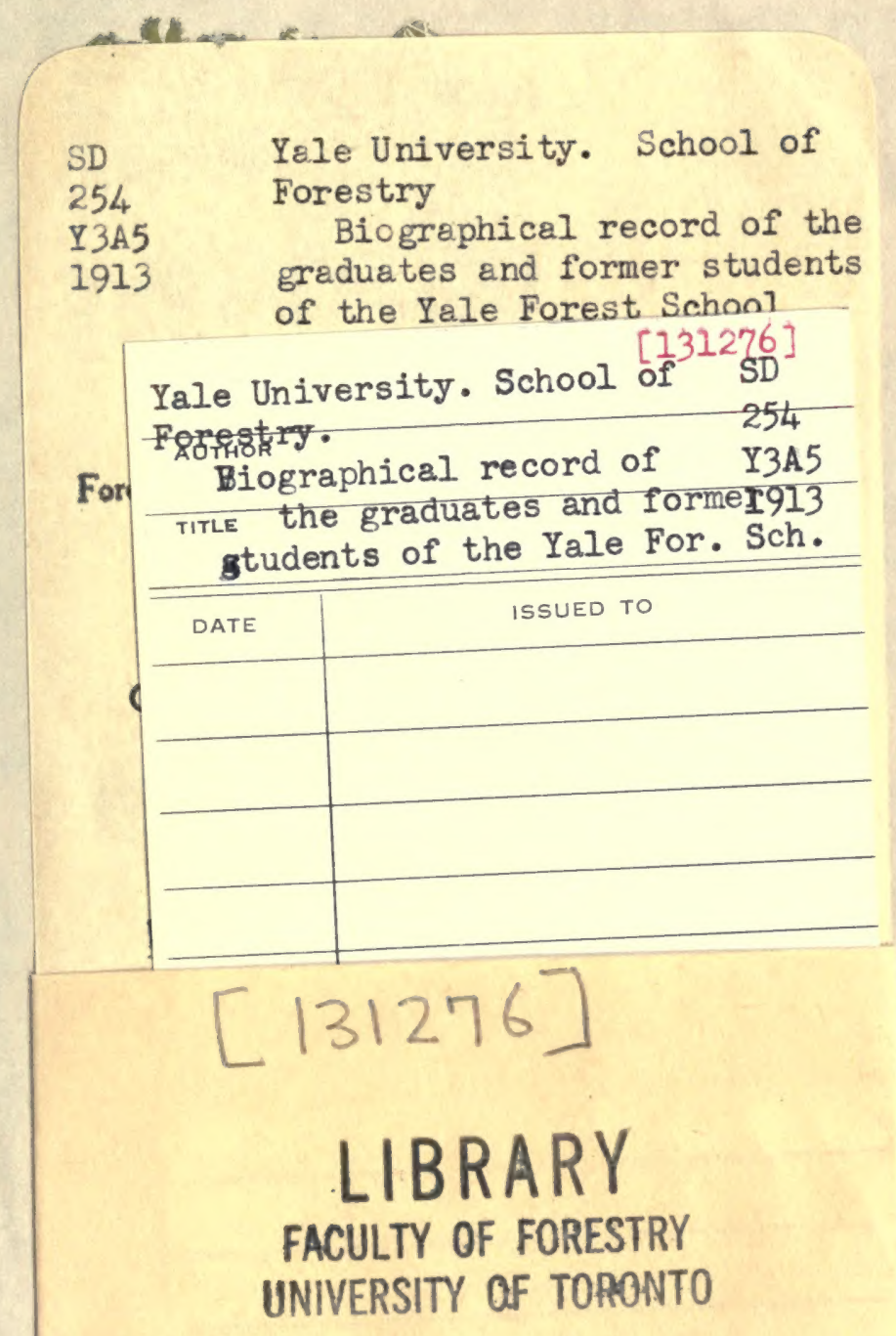


